\title{
ALLDOS-A Computer Program for Calculation of Radiation Doses from Airborne and Waterborne Releases
}

D. L. Strenge

B. A. Napier

R. A. Peloquin

M. G. Zimmerman

October 1980

Prepared for the U.S. Department of Energy under Contract DE-AC06-76RLO 1830

Pacific Northwest Laboratory Operated for the U.S. Department of Energy by Battelle Memorial Institute 
NOTICE

This report was prepared as an account of work sponsored by the United States Government. Neither the United States nor the Department of Energy. nor any of their emplovees. nor any of their contractors, subcontractors, or their emplovees. makes anv warranty, express or implied, or assumes any legal liability or responsibility for the accuracy. completeness or usefulness of any information. apparatus, product or process disclosed, or represents that its use would not infringe privately owned rights.

The views, opinions and conclusions contained in this report are those of the contractor and do not necessarily represent those of the United States Government or the United States Department of Energy.

PACIFIC NORTHWEST LABORATORY operated by

BATTELLE

for the

UNITED STATES DEPARTMENT OF ENERGY

Under Contract DE-ACO6-76RLO 1830

\author{
Printed in the United States of America \\ Available from \\ National Technical Information Service \\ United States Department of Commerce \\ 5285 Port Royal Road \\ Springfield. Virginia 22151
}

Price: Printed Copy s $\therefore$ Microfiche $\$ 3.00$

$\begin{array}{cr}\text {-Pages } & \begin{array}{c}\text { VTIS } \\ \text { Selling Price }\end{array} \\ 001-025 & \$ 4.00 \\ 026-050 & \$ 4.50 \\ 051-075 & \$ 5.25 \\ 076.100 & \$ 6.00 \\ 101-125 & \$ 6.50 \\ 126-150 & \$ 7.25 \\ 151-175 & \$ 8.00 \\ 176-200 & \$ 9.00 \\ 201-225 & \$ 9.25 \\ 226-250 & 59.50 \\ 251-275 & 510.75 \\ 276-300 & 511.00\end{array}$


ALLDOS - A COMPUTER PROGRAM FOR CALCULATION OF RADIATION DOSES FROM AIRBORNE AND WATERBORNE RELEASES

D. L. Strenge

B. A. Napier

R. A. Peloquin

M. G. Zimmerman

October 1980

Prepared for the

U.S. Department of Energy under Contract DE-AC06-76RLO 1830

Pacific Northwest Laboratory Richland, Washington 99352 
The computer code ALLDOS is described and instructions for its use are presented. ALLDOS generates tables of radiation doses to the maximum individual and the population in the region of the release site. Acute or chronic release of radionuclides may be considered to airborne and waterborne pathways.

The code relies heavily on data files of dose conversion factors and environmental transport factors for generating the radiation doses. A source inventory data library may also be used to generate the release terms for each pathway. Codes available for preparation of the dose conversion factors are described and a complete sample problem is provided describing preparation of data files and execution of ALLDOS. 
$-$

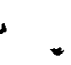




\section{ACKNOWLEDGMENTS}

This work was performed under contract CD0009 for the Department of Energy, Waste Management Division, Richland Operations Office in conjunction with the Low Level Waste Program of Rockwell Hanford Operations. The computer program ALLDOS was used extensively in preparing environmental dose estimates for the Low Level Waste Program.

The authors would like to express appreciation for manuscript preparation by Ruth Laidler and Pattie Freed of PNL. 


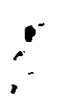

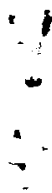

:

$\because$

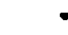




\section{CONTENTS}

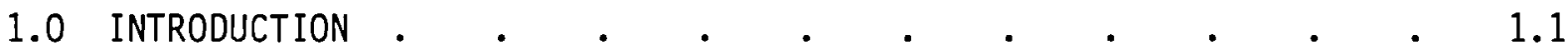

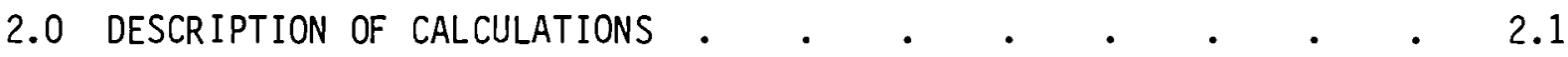

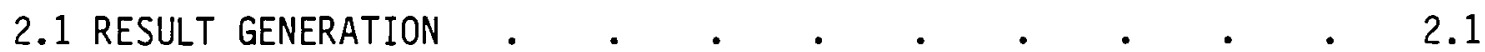

2.2 ENVIRONMENTAL TRANSPORT FACTORS $\quad$ • $\quad$ • $\quad$ • $\quad$ • $\quad$ • $\quad$ • 2.6

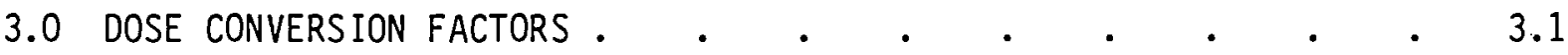

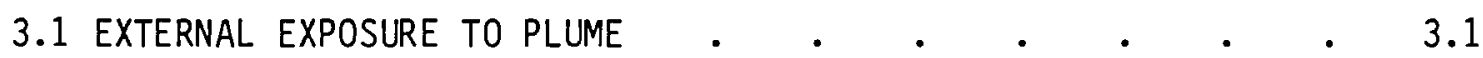

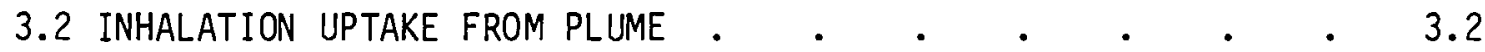

3.3 TERRESTRIAL PATHWAYS FROM AIRBORNE RELEASES . . . . . 3.3

3.4 TERRESTRIAL PATHWAYS FROM WATERBORNE RELEASES $\quad \cdot \quad \cdot \quad \cdot 3.3$

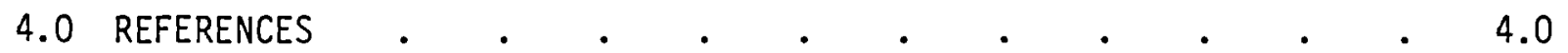

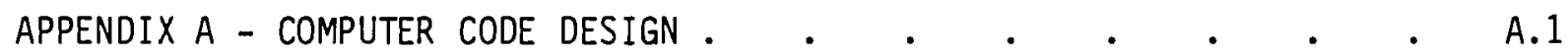

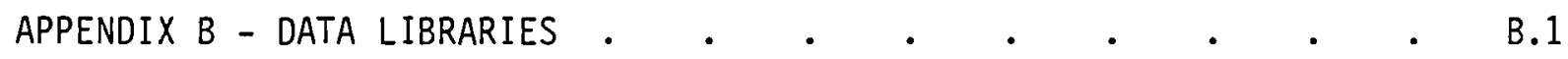

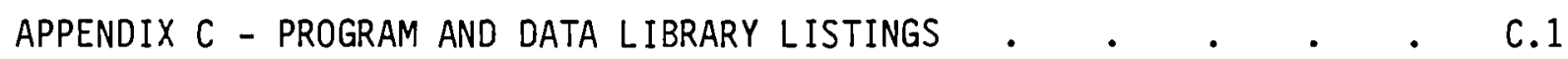

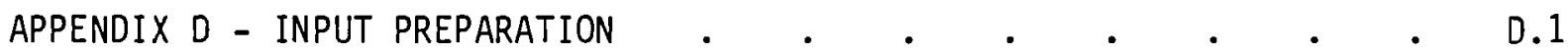

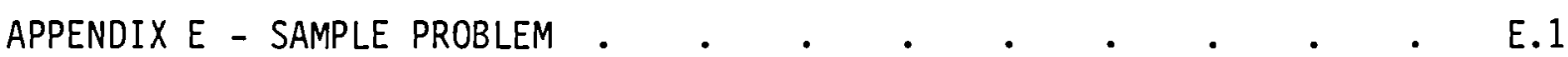


4

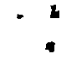

$-$

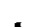

$\rightarrow$ 


\section{$\underline{\text { TABLES }}$}

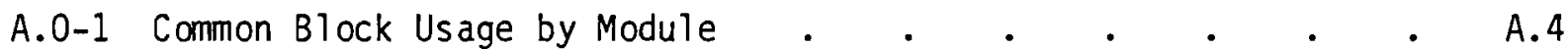

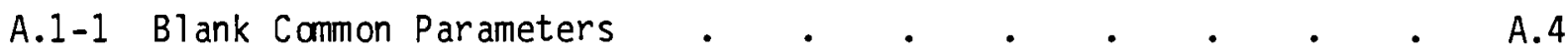

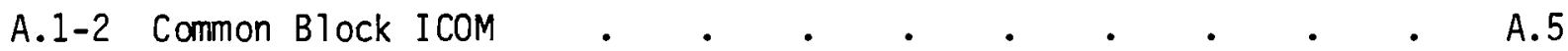

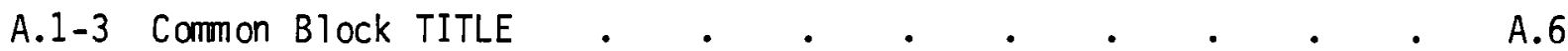

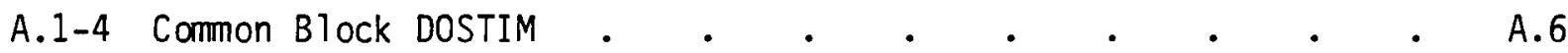

B.1-1 Suggested Organ Index List . . . . . . . . . . B.3

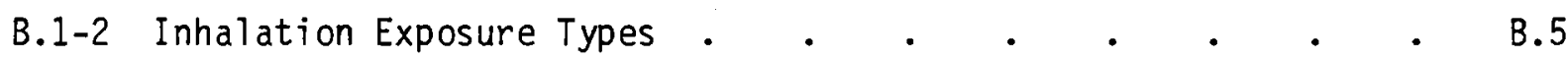

B.2-1 Terrestrial Pathway Data Sets .

E.1-1 Sample Problem Input Parameters . . . . . . . . E.2

E.2-1 DACRIN Sample Problem Organs . . . . . . . . . E.21

E.2-2 DACRIN Sample Problem Input Parameters . . • . • • E.21

E.3-1 PABLM Sample Problem Input Parameters . . . . . E.30 


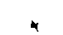

:

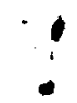

$\therefore$

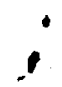

$\because$

$+$ 


\section{$\underline{\text { FIGURES }}$}

A.0-1 Heirarchy Diagram for Main Program ALLDOS . . . . . A.2

A.0.2 Heirarchy Diagram for Subroutine CASEIN . . . . . A.3

A.2-1 Chapin Chart Logic Constructs . . . . . . . A.8

A.2.2 Logic Diagram for ALLDOS • • • • • • • . . . A.10

A.2.3 CASEIN Logic Diagram • • • • • • • • • • . A.12

A.2.4 DFREAD Logic Program . . . . . . . . . . . A.14

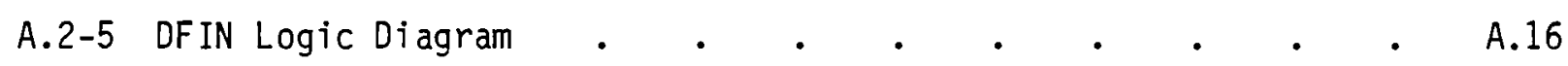

A.2-6 EDORG Logic Diagram • . . . . . . . . . . A.17

A.2-7 SOURCE Logic Diagram • . • • • • • • • . A.21

A.2-8 SQIN Logic Diagram • • • • • • • • • . A.24

C.0-1 Program Listing . . . . . . . . . . $C .2$

C.0-2 File 10 Data Library . . . . . . . . . c. c . c

C.0-3 File 12 Data Library . . . . . . . . . . C.38

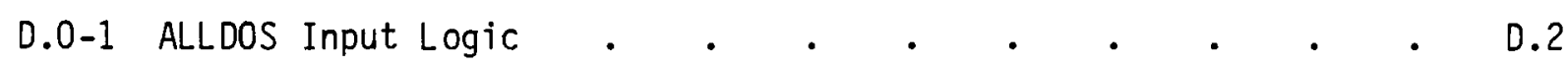

E.1-1 SAMPLE Problem Input Card Listing . . . . . . E.3

E.1-2 ALLDOS Sample Problem Output • . • . • • . E.4

E.2-1 DACRIN Sample Problem Input . . . . . . . E.22

E.3-1 PABLM Sample Problem Input . . . . • . . . E.27

E.4-1 File 15 Sample Basic Inventory • • • • . • • E.32 
i

$\because$

. 


\subsection{INTRODUCTION}

The computer program ALLDOS was prepared for rapid calculation of radiation dose tables with consideration given to all significant exposure pathways.

Three release terms may be specified for each case: airborne release for external and inhalation exposure; airborne release for terrestrial pathways (ingestion/external); and waterborne releases for terrestrial and aquatic pathways (ingestion/external). Separate release source terms are defined for each release pathway to be considered for a given case. An optional procedure is provided for generation of release terms from a basic radionuclide inventory. The basic inventory is multiplied by release factors defined for each radionuclide class and each case.

ALLDOS relies heavily on use of precalculated dose conversion factors to describe terrestrial pathways and radiation dosimetry. Dose conversion factors defined for each release pathway are used to generate dose commitments to a maximum individual and the population in the region of the release site. Acute and chronic releases may be considered. Preparation of dose conversion factors is described in Section 3.0.

The dose reports indicate dose contributions by release pathway plus the total doses to selected organs. The dose contribution fraction by radionuclide for each organ is also reported as an option.

ALLDOS was developed for calculation of radiation doses from postulated releases of aged radioactive wastes. These radionuclides are long-lived with decay half-lives of several weeks or longer. Therefore, radioactive decay in transit from the release point to the location of exposure in the environment is not considered.

The version of ALLDOS described in this document is operable on the UNIVAC $1100 / 44$ operated by Boeing Computing Services for the Department of Energy in Richland, Washington. The structured program was compiled using an ASCII FORTRAN compiler available on the UNIVAC 1100 (FTN processor). Approximately $45 \mathrm{~K}$ (decimal) words of storage are required to execute the program. 


\subsection{DESCRIPTION OF CALCULATIONS}

The primary function of ALLDOS is to calculate maximum individual and population dose tables generated from release inventories and dose conversion factors. As such, ALLDOS contains no models of its own but is merely a report generator. The equations used to generate the result tables are presented in the following section.

\subsection{RESULT GENERATION}

The code ALLDOS considers contributions to dose from three release pathways:

- airborne releases resulting in inhalation and external exposure (referred to as "airborne pathways"),

- airborne releases resulting in exposure through terrestrial pathways (referred to as "terrestrial pathway"),

- waterborne releases resulting in exposure through terrestrial pathways and aquatic pathways (referred to as "waterborne pathway").

Dose results are generated using radionuclide release terms for each pathway multiplied by appropriate dose conversion factors supplied for each pathway.

Two methods are available for specification of the release inventories:

- direct input from cards of activity released for each radionuclide and each pathway,

- input of a basic radionuclide inventory from which release inventories are calculated using release factors for each pathway and radionuclide.

The first method is useful for runs involving inventories to be considered only once or twice. However, when a basic inventory can be defined for use with several release cases, or when parametric studies are to be performed, then the second method may greatly reduce the effort required to run ALLDOS. The second method involves establishing a basic radionuclide inventory such as the activity (in curies) of each fission product in reprocessed waste per metric ton of heavy metal. This data file may be supplied to ALLDOS by card input or as a data library on File 15. The actual release for each pathway is calculated using release factors defined for each pathway and each radionuclide class. This calculation may be represented by the following equations: 


$$
\begin{aligned}
& Q_{a}^{i}=F_{a i} \cdot Q_{0 i} \\
& Q_{t}^{i}=F_{t i} \cdot Q_{0 i} \\
& Q_{f}^{i}=F_{f i} \cdot Q_{0 i}
\end{aligned}
$$

where

$Q_{a}^{i}$ - release of radionuclide $i$ to airborne pathway, $\mathrm{C} i /$ year

$Q_{t}^{i}$ - release of radionuclide $i$ to waterborne pathway, Ci/year

$Q_{f}^{i}$ - release of radionuclide $i$ to terrestrial pathway, Ci/year

$Q_{0 i}$ - activity of radionuclide $i$ in the basic inventory

$F_{\text {ai }}$ - fraction of radionuclide $i$ in the basic inventory that is released to the airborne pathway, year ${ }^{-1}$

$\mathrm{F}_{t i}$ - fraction of radionuclide in in the basic inventory that is released to the waterborne pathway, year ${ }^{-1}$

$\mathrm{F}_{\mathrm{f} i}$ - fraction of radionuclide in in the basic inventory that is released to the terrestrial pathway, year ${ }^{-1}$

The above equations apply to chronic releases ( 1 year or longer) and to acute releases. However, for acute releases the fractions give total activity released rather than activity per year. When the first method for release inventory specification is used, the parameters $Q_{a}^{i}, Q_{t}^{i}$ and $Q_{f}^{i}$ are supplied directly on cards.

To simplify input the release factors $F_{a j}, F_{t i}$ and $F_{f i}$ are supplied by radionuclide class rather than by each radionuclide. The class definitions are specified through input with up to 80 classes allowed. The defined classes are used for all release pathways. The basic inventory has a class associated with each radionuclide entry. A given radionuclide may have more than one entry by specifying different classes for each entry. When this is done the total release for the radionuclide is the sum over all entries multiplied by the appropriate release factors. For example, if radionuclide $i$ has three entries designated by (1), (2) and (3) then the total release for the terrestrial pathway is given by 


$$
Q_{f}^{i}=F_{f i}(1) Q_{0 i}(1)+F_{f j}(2) Q_{0 i}(2)+F_{f i}(3) Q_{o j}(3)
$$

where

$F_{f j}(j)$ - release factor for the $j$-th contribution to the terrestrial release term of radionuclide $i$, year ${ }^{-1}$,

$Q_{0 i}(j)$ - basic inventory of the $j$-th entry for radionuclide $i$, curies. When this method is used to generate the release terms a report is printed showing all non-zero contributions for all radionuclides in the release terms.

The release terms are used to generate dose result tables for the maximum individual and the population using dose conversion factors and environmental transport factors. The dose conversion factors are defined for each release pathway, release period and dose commitment period. A detailed description of dose conversion factor preparation is given in Section 3.0. The dose conversion factors are supplied to ALLDOS as data libraries (see Appendix B).

The environmental transport factors (see Section 2.2) include consideration of atmospheric dispersion, waterborne dispersion and population distribution. For releases lasting longer than one year a "plant-life" factor is also applied to the airborne release pathway doses. This is necessary because the airborne pathway dose conversion factors are normalized to one curie total release rather than to a release rate of one curie per year (as for the terrestrial pathway and waterborne pathway).

The doses are calculated for the maximum individual as follows:

$$
\begin{aligned}
& A_{m T}^{i}=E_{x}^{i} Q_{a}^{i}(E / Q)_{a} T_{c} \\
& B_{m T o}^{i}=D A_{O T}^{i} Q_{a}^{i}(E / Q)_{a} T_{c} \\
& C_{m T o}^{i}=D T_{O T}^{m i} Q_{f}^{i}(E / Q)_{t} \\
& D_{m T o}^{i}=D F_{O T}^{m i} Q_{t}^{i} F_{m} \\
& M_{d T o}^{i}=A_{m T}^{i}+B_{m T o}^{i}+C_{m T o}^{i}+D_{m T o}^{i}
\end{aligned}
$$


where

$A_{m T}^{i}$ - dose contribution from external exposures to radionuclide $i$ (airborne pathway) for the maximum individual for exposure period $T$, rem

$E_{x}^{i}$ - external dose conversion factor for radionuclide $i$, rem per $\left(\mathrm{Ci} \cdot \mathrm{sec} / \mathrm{m}^{3}\right)$

$(E / Q)_{a}$ - time-integrated air concentration at the location of the maximum individual for the airborne pathway, $\mathrm{sec} / \mathrm{m}^{3}$

$T_{C}$ - plant-life factor based on the release duration, years. For short releases $T_{C}$ is set to 1.0

$\mathrm{B}_{\mathrm{mTo}}^{i}$ - maximum individual dose contribution to organ o from inhalation uptake of radionuclide $i$ (airborne pathway) for exposure period $T$, rem

DA ${ }_{O T}^{i}$ - inhalation dose conversion factor for radionuclide $i$, organ 0 and exposure period $\mathrm{T}$, rem per $\left(\mathrm{Ci} \cdot \mathrm{sec} / \mathrm{m}^{3}\right)$

$\mathrm{C}_{\mathrm{m} \text { To }}^{i}$ - maximum individual dose contribution to organ o and radionuclide i from airborne terrestrial pathways for exposure period $T$, rem

$(E / Q)_{t}$ - time-integrated air concentration for the maximum individual for the terrestrial pathway, $\mathrm{sec} / \mathrm{m}^{3}$

$\mathrm{DT}_{\mathrm{OT}}^{\mathrm{mi}}$ - maximum individual airborne release dose conversion factor for organ 0 , and radionuclide $i$ and exposure period $T$, rem per $\left(\mathrm{sec} / \mathrm{m}^{3}\right)$ per $(\mathrm{Ci} /$ year $)$

$\mathrm{D}_{\mathrm{m} T \mathrm{o}}^{\mathrm{i}}$ - maximum individual dose contribution to organ 0 and radionuclide $i$ from waterborne release pathways for exposure period $T$, rem

$\mathrm{OF}_{\mathrm{OT}}^{\mathrm{mi}}$ - maximum individual waterborne release dose conversion factor for organ 0 , radionucide $i$ and exposure period $T$, rem.sec $/ \mathrm{ft}^{3}$ per $\mathrm{Ci} /$ year

$F_{m}$ - maximum individual waterborne release environmental transport factor, $\mathrm{sec} / \mathrm{ft}^{3}$

$M_{d T o}^{i}$ - total dose to the maximum individual for organ 0 , radionuclide $i$ and exposure period $T$, rem.

The waterborne pathway dose conversion factor is normalized to the river flow rate used as the source of contaminated water and to one curie release. 
In the above equations the exposure period representation $T$ is used to define both the uptake period and the dose commitment period. The data libraries of dose conversion factors generally provide data for acute release, chronic release for one year and chronic release for several years (i.e., for the plant-life). Dose commitment periods generally considered are one year and fifty years.

The equations used to calculate the population doses are similar to Equations 2.1-5 through 2.1-9 with the environmental transfer factors $(E / Q)_{a}$, $(E / Q)_{t}$ and $F_{m}$ replaced by $P M_{a}, P M_{t}$ and $F_{p}$ respectively. Also the terrestrial dose conversion factors $\mathrm{DT}_{\text {ot }}^{\mathrm{mi}}$ and $\mathrm{DF}_{\text {ot }}^{\mathrm{mi}}$ are replaced by DT $\mathrm{PT}_{\mathrm{OT}}^{\mathrm{i}}$ and $\mathrm{DF} \mathrm{OT}_{\mathrm{OT}}^{\mathrm{Pi}}$ respectively. The resulting equations are

$$
\begin{aligned}
& A_{p T}^{i}=E_{x}^{i} Q_{a}^{i} P M_{a} T_{c} \\
& B_{p T o}^{i}=D A_{o T}^{i} Q_{a}^{i} P M_{a} T_{c} \\
& C_{p T o}^{i}=D T_{o T}^{p i} Q_{f}^{i} P M_{t} \\
& D_{p t o}^{i}=D F_{o t}^{p i} Q_{t}^{i} F_{p} \\
& P_{p T o}^{i}=A_{p T}^{i}+B_{p T o}^{i}+C_{p T o}^{i}+D_{p T o}^{i}
\end{aligned}
$$

where

$$
\begin{aligned}
& A_{p T}^{i} \text { - population dose contribution from external exposure to radio } \\
& \mathrm{PM}_{\mathrm{a}} \text { - population weighted time-integrated air concentration factor, } \\
& \operatorname{man} \cdot \sec / \mathrm{m}^{3} \text {, } \\
& \mathrm{B}_{\mathrm{pTO}}^{i} \text { - population dose contribution to organ o from inhalation uptake of } \\
& \text { radionuclide } i \text { for exposure period } T \text {, man-rem, } \\
& C_{\text {pTo }}^{i} \text { - population dose contribution to organ o and radionuclide } i \text { from } \\
& \mathrm{DT}_{\mathrm{OT}}^{\mathrm{mi}} \text { - airborne release population dose conversion factor for organ } 0 \text {, } \\
& \text { radionuclide } i \text { and exposure period } T \text {, rem per }\left(\mathrm{sec} / \mathrm{m}^{3}\right) \text { per } \\
& \text { (Ci/year), }
\end{aligned}
$$


$\mathrm{PM}_{\mathrm{T}}$ - population weighted time-integrated air concentration factor for terrestrial pathways, $m a n \cdot s e c / m^{3}$,

$D_{\text {pTo }}^{i}$ - population dose contribution to organ o and radionuclide $i$ from the waterborne terrestrial pathways for exposure period T, man-rem,

$D_{T 0}^{p i}$ - waterborne release population dose conversion factor for organ 0 , radionuclide $i$ and exposure period $T$, rem.sec/ft ${ }^{3}$ per $C i / y e a r$,

$F_{p}$ - population waterborne release environmental transport factor, $\operatorname{man} \cdot \sec / \mathrm{ft}^{3}$.

\subsection{ENVIRONMENTAL TRANSPORT FACTORS}

The transport and dispersion of released activity is described by environmental transport factors. These factors are defined for each release pathway for the maximum individual and the population. The maximum individual transport factors are:

$(E / Q)_{a}$ - time integrated air concentration at the location of the maximum individual for the airborne release pathway, $\mathrm{sec} / \mathrm{m}^{3}$,

$(E / Q)_{t}$ - time-integrated air concentration at the location of the maximum individual for the terrestrial pathway, $\mathrm{sec} / \mathrm{m}^{3}$

$\mathrm{F}_{\mathrm{m}}$ - waterborne release pathway dilution factor, sec/ $\mathrm{ft}^{3}$.

The waterborne release transport factor is the inverse of the flow rate of the river receiving the contamination.

The population transport factors are:

$P M_{a}$ - population weighted time-integrated air concentration for the airborne release pathway, man.sec $/ \mathrm{m}^{3}$,

$F_{p}$ - waterborne release pathway population weighted dilution factor, $\mathrm{man} \cdot \mathrm{sec} / \mathrm{ft}^{3}$.

The population weighted air transport factors $\mathrm{PM}_{\mathrm{a}}$ and $\mathrm{PM}_{t}$ may be represented as follows:

$$
P M_{a}=\sum_{i}^{\text {locations }} P_{i}(E / Q)_{i}
$$


where

$$
P_{i} \text { - population within area } i \text {, persons }
$$

$(E / Q)_{j}$ - average normalized time-integrated air concentration within area $i, \sec / \mathrm{m}^{3}$

$i$ - location index to include all populated areas near the release site.

The transport factor $P M_{t}$ is calculated by Equation 2.2-1 also with appropriate values for $(E / Q)_{i}$. For most situations the values of $P M_{a}$ and $P M_{t}$ are the same.

The waterborne factor $F_{p}$ may be considered to be the population served by contaminated produce divided by the receiving river flow rate. All of the above transport factors are defined for use with the dose conversion factors provided in the data Tibraries (see Section 3.0 and Appendix B). 


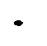

$\div$

:

0

$\because$

- 


\subsection{DOSE CONVERSION FACTORS}

This section describes preparation of dose conversion factors required by ALLDOS. Four types of dose conversion factors are supplied in the two data libraries:

File 10 library:

- external exposure to plume,

- inhalation uptake from plume,

File 12 library:

- airborne terrestrial pathways,

- waterborne terrestrial pathways.

Each of these factors is described in the following sections.

\subsection{EXTERNAL EXPOSURE TO PLUME}

The external dose conversion factor ( $E_{x}^{i}$ of Equations 2.1-5 and 2.1-10) gives the dose from gamma radiation to an individual exposed to an infinite plume of a radionuclide. The factors are normalized to a time-integrated air concentration of one $\mathrm{Ci} \cdot \mathrm{sec} / \mathrm{m}^{3}$ over the time of plume passage. For radionuclides that have significant beta radiations, consideration should be given to Bremsstrahlung radiation contributions to the external dose factors. The external dose conversion factors may be calculated as:

$$
E_{x}^{i}=0.23 \sum_{j=1}^{\text {photons }}\left(E_{\gamma j}^{i}+E_{B j}^{i}\right) f_{a j}^{i}\left(1+\mu_{j} d\right) e^{-\mu_{j} d}
$$

where

\footnotetext{
$E_{x}^{i}$ - external dose conversion factor for radionuclide $i$, rem per $\left(\mathrm{C} \cdot \mathrm{sec} / \mathrm{m}^{3}\right)$,

$E_{Y j}^{i}$ - total photon energy emitted per dissintegration by radionuclide i for energy group $j$, MeV per dis,

$E_{B j}^{i}$ - effective photon energy in the form of Bremsstrahlung from beta emissions of radionuclide $i$ for energy group $j$, MeV per dis,
} 
$f_{a j}^{i}$ - effective ratio of photon absorption for tissue relative to air (dimensionless) for radionuclide $i$ and energy group $j$,

$\mu_{j}$ - linear total attenuation coefficient of tissue (approximated by water) for photons of energy group $\mathrm{j}, \mathrm{cm}^{-1}$,

d tissue depth for which dose is to be calculated, $\mathrm{cm}$,

0.23 - unit conversion factor, rem (MeV/dis) per $\left(\mathrm{Ci} \cdot \mathrm{sec} / \mathrm{m}^{3}\right)$

$$
0.23=\frac{1}{2} \cdot \frac{3.7 \times 10^{10}\left(\frac{\mathrm{dis}}{\mathrm{Ci} \cdot \mathrm{sec}}\right) 1.6 \times 10^{-6}\left(\frac{\mathrm{erg}}{\mathrm{MeV}}\right)}{100\left(\frac{\mathrm{erg}}{\mathrm{g} \cdot \mathrm{rad}}\right) 1293\left(\frac{\mathrm{g}}{\mathrm{m}^{3}}\right)}
$$

The factor of $1 / 2$ accounts for the fact that the plume is semi-infinite (bounded by the ground plane).

The external doses calculated by ALLDOS are representative of the average dose to the blood forming organs which are assumed to be at a tissue depth of $5 \mathrm{~cm}$ (parameter $d$ in Equation 3.1-1). This dose is also a good approximation for other organ doses (NCRP 1975) and is used to determine the external dose contribution to all organs.

\subsection{INHALATION UPTAKE FROM PLUME}

The inhalation dose conversion factors give the dose commitment from inhalation uptake during plume passage. Like the external dose conversion factors, the inhalation factors are normalized to the time-integrated air concentration over the uptake period. The inhalation dose factors of file 10 are given for acute, chronic and prolonged (30 year) releases and for two dose commitment periods (see Table B.1-2 in Appendix B). Generation of the current File 10 inhalation dose factors was performed using the computer program DACRIN (Houston, Strenge and Watson 1976; Strenge 1975). The program DACRIN employs the respiratory tract model adopted by the ICRP Task Group on Lung Dynamics (ICRP 1966; ICRP 1972). The gastrointestinal tract model and the retention model for other organs are those of the initial ICRP publication (1959). The sample problem in Appendix E (Section E.2) describes input to DACRIN. 


\subsection{TERRESTRIAL PATHWAYS FROM AIRBORNE RELEASES}

The dose conversion factors for terrestrial pathways related to atmospheric releases give the accumulated dose from continued exposure to environmental contamination. The terrestrial dose factors for airborne releases are given in File 12 for both chronic and acute releases (see Appendix $E$ for the structure of file 12). The dose factors are normalized to releases of one curie per year for chronic releases and to one curie for acute releases, with unit values for $X / Q$. The information in File 12 implicitly contains many of the assumptions about demography and lifestyle required; therefore the file must be established on a site-specific basis. Generation of File 12 is performed using the computer program PABLM (Napier, Kennedy, and Soldat 1980).

File 12 contains accumulated dose factors for both an average and a maximum individual. The average parameters are multiplied by a population distribution to obtain a collective dose by ALLDOS. Dose factors are included for one-year doses and accumulated doses from both acute and chronic releases. Factors for up to five organs may be included. The factors are calculated based on all the desired exposure pathways and summed. All dietary and recreational habit information is thus worked into the dose factor, making File 12 site-specific.

\subsection{TERRESTRIAL PATHWAYS FROM WATERBORNE RELEASES}

The dose conversion factors for terrestrial and aquatic exposure pathways also give accumulated dose from continued exposure to environmental contamination. The factors for accumulated dose from waterborne pathways are given in File 12 (see Appendix E) for both acute and chronic releases. The dose factors are normalized to releases of one curie per year for chronic releases and to one curie for acute releases, with no dilution in receiving waters. Dilution is handled in ALLDOS. Like the terrestrial pathway dose factors from atmospheric releases, many of the supporting assumptions are incorporated in these site-specific factors. These dose factors are also calculated using the program PABLM. Included in each dose factor may be contributions from irrigated food crops, farm animals, drinking water, aquatic foods, and external irradiation from contaminated soils, sediments, and water. 


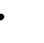

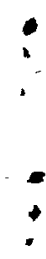

$r$

,

- 


\subsection{REFERENCES}

Houston, J. R., D. L. Strenge and E. C. Watson. 1976. DACRIN - A Computer Program for Calculating Organ Doses from Acute or Chronic Radionuclide Inhalation. BNWL-B-389, Pacific Northwest Laboratory, Richland, WA.

International Commission on Radiological Protection (ICRP). 1959. Report of Committee II on Permissible Dose for Internal Radiation. ICRP Publication 2, Pergamon Press, New York.

International Commission on Radiological Protection (ICRP). 1966. Deposition and Retention Models for Internal Dosimetry of the Human Respiratory Tract. Health Phys. 12:173-207.

International Commission on Radiological Protection (ICRP). 1972. The Metabolism of Compounds of Plutonium and 0ther Actinides. ICRP Publication 19, Pergamon Press, New York.

Napier, B. A., W. E. Kennedy, Jr, and J. K. Soldat. 1980. PABLM - A Computer Program to Calculate Accumulated Radiation Dose from Radionuclides in the Environment, PNL-3209, Pacific Northwest Laboratory, Richland, WA.

National Council on Radiation Protection and Measurements (NCRP). 1975. Natural Background Radiation in the United States. Report No. 45, NCRP, Washington, DC.

Strenge, D. L. 1975. DACRIN - A Computer Program for Calculating Organ Doses from Acute or Chronic Radionuclide Inhalation: Modification for Gastrointestinal Tract Dose. BNWL-B-389 Supp., Pacific Northwest Laboratory, RichTand, MA. 
1
. 
APPENDIX A

COMPUTER COOE DESIGN

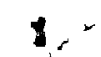


APPENDIX A

\section{COMPUTER CODE DESIGN}

The computer code ALLDOS was developed using structured design and programming techniques. The current version is executed on the UNIVAC 1100/44 operated for the Department of Energy by Boeing Computer Services at Richland, Washington. The programming language is ASCII FORTRAN as implemented by the UNIVAC 1100 FTN compiler.

The program is composed of 18 structured modules plus four common blocks. The module hierarchy is indicated in Figures A.0-1 and A.0-2. These figures onty indicate calling sequence; no logic structure is implied. A brief description of the primary function of each module is also indicated in the hierarchy diagrams. A list of the 18 modules and usage of common blocks is given in Table A.0-1.

The majority of data transfer between modules is accomplished through argument lists. Some data transfer is also done using the four common blocks described in Section A.1.

The following sections provide details of the common blocks and module design specifications. A complete listing of the FORTRAN code is given in Appendix $C$.

\section{A.1 COMMON BLOCKS}

The four common blocks used in ALLDOS and their general purposes are:

blank - transfer input inventories and calculated doses

DOSTIM - transfer dose commitment period information

ICOM - transfer input NAMELIST parameters

TITLE • transfer input inventory title information.

Descriptions of each common block are given in Tables A.1-1 through A.1-4. 


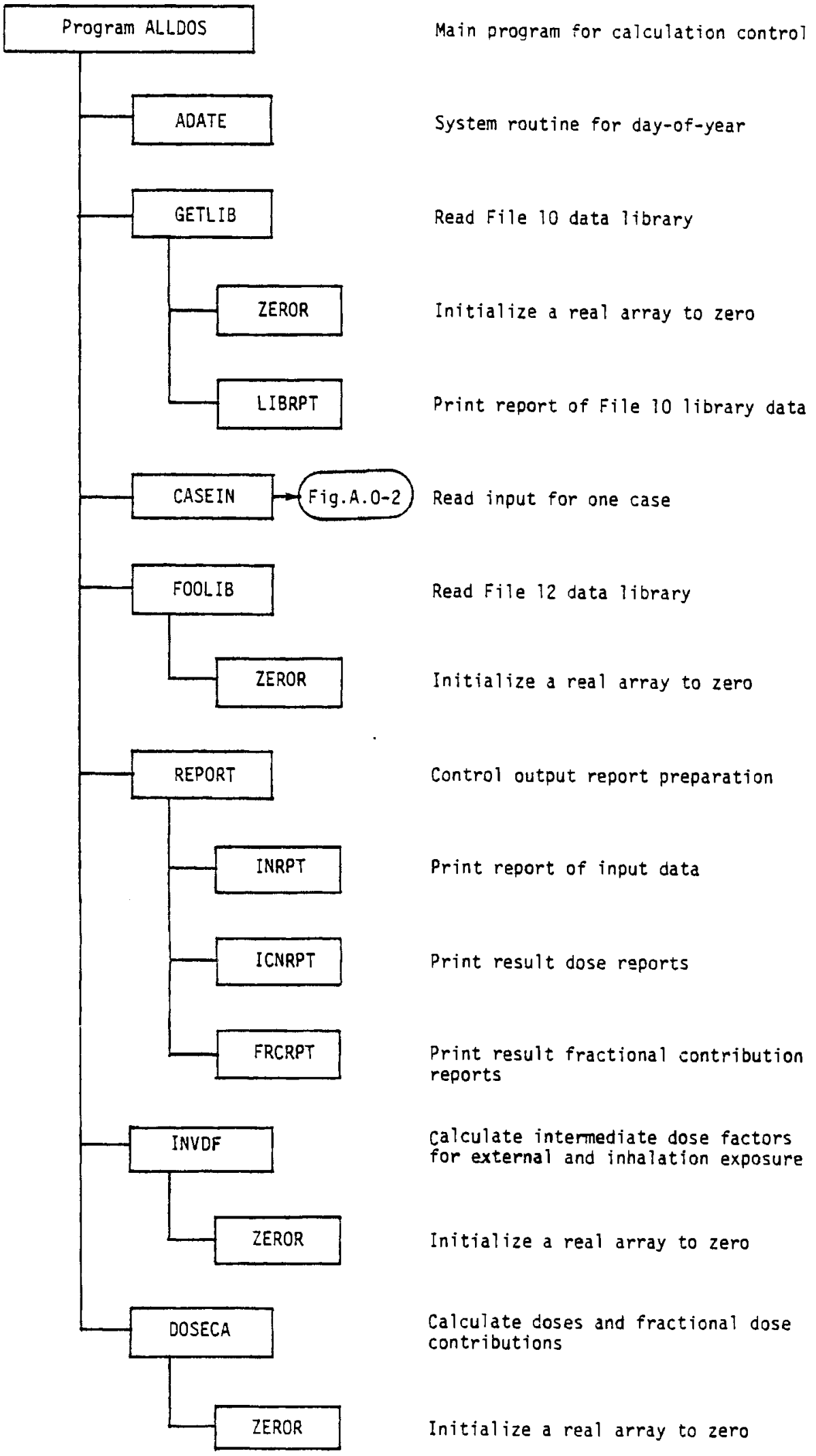

FIGURE A.0-1. Hierarchy Diagram for Main Program ALLDOS 


\section{Subroutine CASEIN}

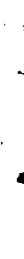

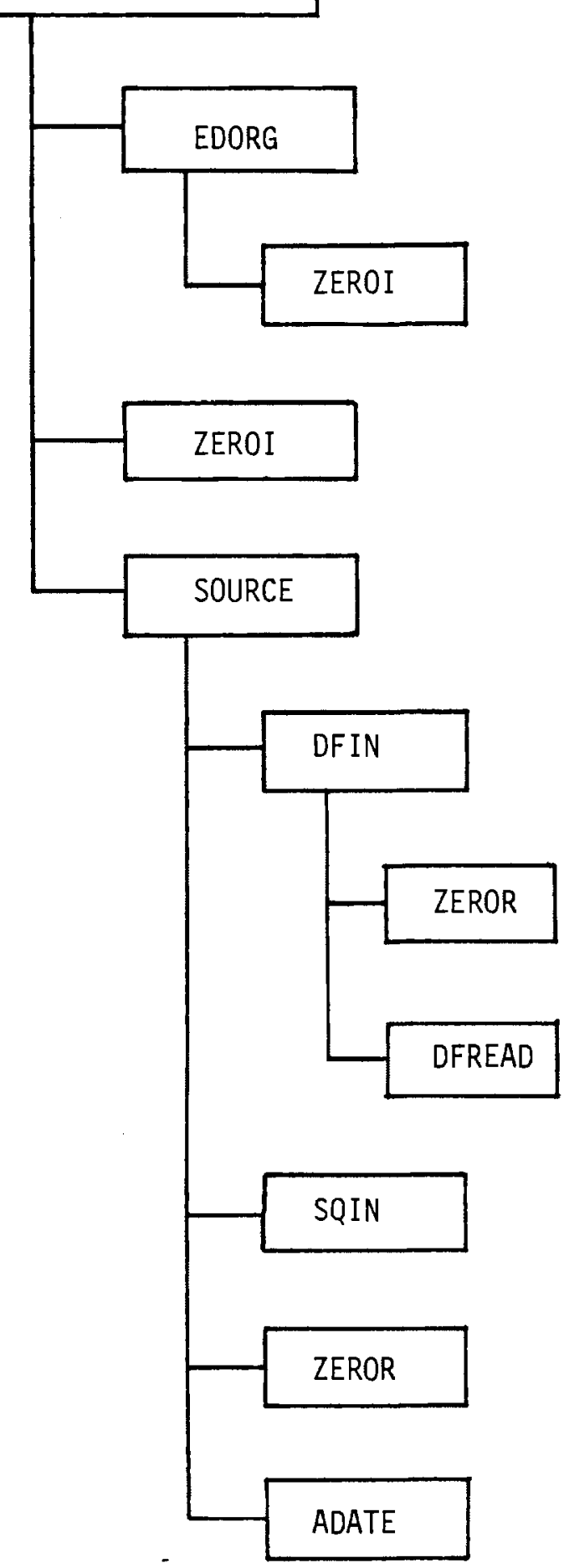

Read input for one case

Edit input organ selection

Initialize an integer array to zero

Initialize an integer array to zero

Generate a source term using input inventory and release factors

Control input of release factors

Initialize a real array to zero

Read release factors from cards

Input source inventory from cards or File 15

Initialize a real array to zero

System routine for day-of-year

FIGURE A.0-2. Hierarchy Diagram for Subroutine CASEIN (Called by ALLDOS) 
TABLE A.0-1 Common Block Usage by Module

\begin{tabular}{|c|c|c|c|c|}
\hline \multirow{2}{*}{$\begin{array}{c}\text { Module } \\
\text { Name }\end{array}$} & \multicolumn{4}{|c|}{ Common Blocks Used } \\
\hline & Blank Common & ICOM & TITLE & DOSTIM \\
\hline ALLDOS & used & used & - & - \\
\hline CASEIN & used & used & - & - \\
\hline DF IN & - & - & - & - \\
\hline DFREAD & - & - & - & - \\
\hline DOSECA & used & - & - & - \\
\hline EDORG & - & - & - & - \\
\hline FOOLIB & - & - & - & - \\
\hline FRCRPT & used & used & used & used \\
\hline GETLIB & - & - & - & used \\
\hline ICNRPT & - & - & used & used \\
\hline INRPT & used & - & - & used \\
\hline INVDF & - & - & - & - \\
\hline LIBRPT & - & - & - & used \\
\hline REPORT & used & - & - & - \\
\hline SOURCE & used & - & used & - \\
\hline SQIN & - & - & used & - \\
\hline ZEROI & - & - & - & - \\
\hline ZEROR & - & - & - & - \\
\hline
\end{tabular}

\section{TABLE A.1-1 Blank Conmon Parameters}

\begin{tabular}{lll} 
Parameter & Type & \multicolumn{1}{c}{ Description } \\
\hline TC & Real & $\begin{array}{l}\text { Plant life, years, used for prolonged release } \\
\text { calculations and for acute release when } L Y=3 .\end{array}$ \\
SQ(350) & Real & $\begin{array}{l}\text { Basic radionuclide inventory activities, curies. } \\
\text { PDOSC }(5,2,100)\end{array}$ \\
Real & $\begin{array}{l}\text { Population dose storage array for } 5 \text { organs, 2 } \\
\text { time periods and 100 radionuclides, man-rem. }\end{array}$ \\
DMAXC $(5,2,100)$ & Real & $\begin{array}{l}\text { Maximum individual dose storage array for } 5 \\
\text { organs, 2 time periods and 100 radionuclides, } \\
\text { man-rem. }\end{array}$
\end{tabular}


TABLE A.1-2 Common Block ICOM

\begin{tabular}{|c|c|c|}
\hline Parameter & Type & Description \\
\hline LR & Integer & $\begin{array}{l}\text { Release type control integer: } \\
L R=1 \text { for acute release, } \\
L R=2 \text { for chronic release. }\end{array}$ \\
\hline NREL & Integer & $\begin{array}{l}\text { Number of release pathways to be considered: } \\
2 \leq \mathrm{NREL} \leq 3 \text {. }\end{array}$ \\
\hline LPOP & Integer & $\begin{array}{l}\text { Population dose calculation control integer; } \\
\text { LPOP }>0 \text { to include population dose calculations. }\end{array}$ \\
\hline LFCT & Integer & $\begin{array}{l}\text { Control integer for printing special output } \\
\text { reports. }\end{array}$ \\
\hline LM & Integer & $\begin{array}{l}\text { Maximum individual dose calculation control } \\
\text { integer; LM }>0 \text { to include maximum individual } \\
\text { dose calculation. }\end{array}$ \\
\hline LY & Integer & $\begin{array}{l}\text { Control integer for calculation of the second } \\
\text { dose commitment period doses. }\end{array}$ \\
\hline INV & Integer & Release inventory specification control integer. \\
\hline PM & Rea 1 & $\begin{array}{l}\text { Population weighted air transport factor for the } \\
\text { airborne pathway, } \mathrm{PM}_{\mathrm{a}} \text {, man.sec } / \mathrm{m}^{3} \text {. }\end{array}$ \\
\hline$X Q M$ & Real & $\begin{array}{l}\text { Maximum individual time-integrated air concentra- } \\
\text { tion for the airborne pathway, }(E / Q)_{a}, \mathrm{sec} / \mathrm{m}^{3} \text {. }\end{array}$ \\
\hline FPM & Real & $\begin{array}{l}\text { Population weighted air transport factor for the } \\
\text { terrestrial pathway, } \mathrm{PM} \text {, } \operatorname{man} \cdot \mathrm{sec} / \mathrm{m}^{3} \text {. }\end{array}$ \\
\hline FXQM & Real & $\begin{array}{l}\text { Maximum individual time-integrated air concentra- } \\
\text { tion for the terrestrial pathway, }(E / Q)_{t} \text {, } \\
\mathrm{sec} / \mathrm{m}^{3} \text {. }\end{array}$ \\
\hline FLOW & Real & $\begin{array}{l}\text { Maximum individual environmental transport factor } \\
\text { for the waterborne pathway, } F_{m} \text {, sec/ft3. }\end{array}$ \\
\hline PFLOW & Real & $\begin{array}{l}\text { Population environmental transport factor for the } \\
\text { waterborne pathway, } F_{p} \text {, man.sec/ } / \mathrm{ft}^{3} \text {. }\end{array}$ \\
\hline IPATH & Integer & Release pathway selection index. \\
\hline
\end{tabular}


TABLE A.1-3 Common B lock TITLE

\begin{tabular}{|c|c|c|}
\hline Parameter & Type & Description \\
\hline $\operatorname{DSET}(5)$ & Character & $\begin{array}{l}\text { This array gives the title for the } \\
\text { basic inventory set read from File } 15 \text {. }\end{array}$ \\
\hline
\end{tabular}

TABLE A.1-4 Common Block DOSTIM

\begin{tabular}{|c|c|c|}
\hline Parameter & Type & Description \\
\hline IDT IME (4) & Integer & $\begin{array}{l}\text { This array gives time periods (years) for which } \\
\text { inhalation dose conversion factor are supplied. } \\
\begin{aligned} \operatorname{IDTIME}(1)= & \text { dose commitment period } 1 \\
\operatorname{IDTIME}(2)= & \text { dose commitment period } 2 \\
\operatorname{IDTIME}(3)= & \text { dose commitment period } 2 \\
& \text { for prolonged releases } \\
\text { IDTIME }(4)= & \text { uptake period for prolonged } \\
& \text { release. }\end{aligned}\end{array}$ \\
\hline
\end{tabular}




\section{A.2 MODULE SPECIFICATIONS}

This section gives design specifications and detailed information (useful for programmers when making modifications to the program) for the main program and subroutines related to data card input. The information is presented in tabular form giving:

- primary function of module

- common block usage

- subordinate routines required

- argument list definitions

- details of module operation

- error messages

- logic diagrams

The above items are included as required for each module. The logic diagrams use flowcharting techniques described by chapin (1974)* and are referred to as chapin charts. The basic logic constructs used in the diagrams are indicated in Figure A.2-1.

\section{A.2.1 ALLDOS (Main Program)}

This module controls reading of data libraries, input of case data, calculation of results and reporting of results through calls to appropriate subroutines. Common block ICOM and blank common are included in ALLDOS. The following modules are called by ALLDOS.

\begin{tabular}{ll} 
Module & \multicolumn{1}{c}{ Purpose } \\
GETLIB & Read File 10 data library \\
CASEIN & $\begin{array}{l}\text { Read input card data and File } 15 \text { data (if required) for } \\
\text { one case }\end{array}$ \\
FOOLIB & Read File 12 terrestrial pathway dose conversion factors \\
REPORT & $\begin{array}{l}\text { Print input data report and result reports } \\
\text { INVDF }\end{array}$ \\
DOSECA & $\begin{array}{l}\text { Calculate intermediate factors for external and inhala- } \\
\text { this case }\end{array}$ \\
thin, N. 1974. & "New Format for Flowcharts", Software - Practice and
\end{tabular}




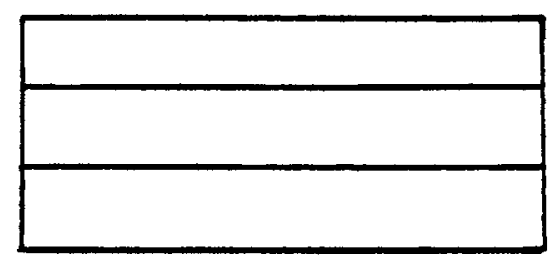

Sequential Block of Code

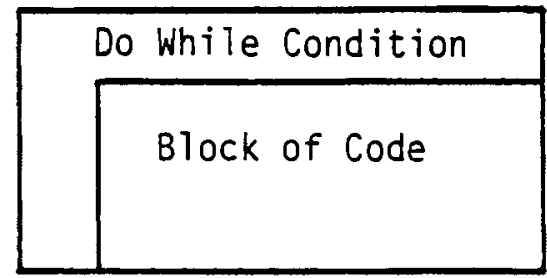

Do While Loop

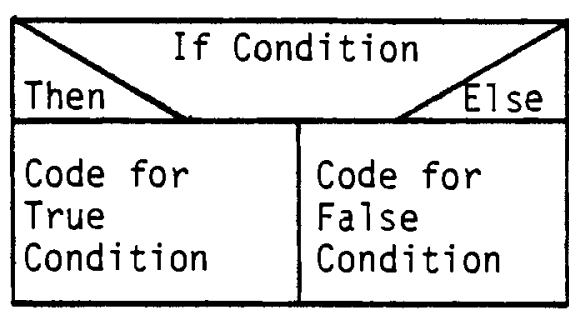

Conditional

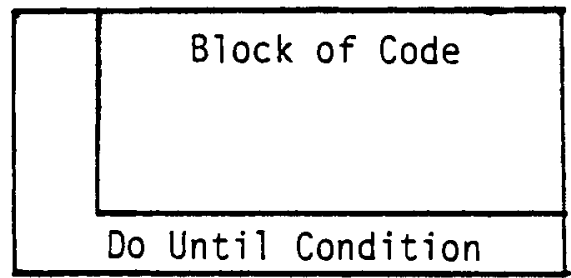

Do Until Loop

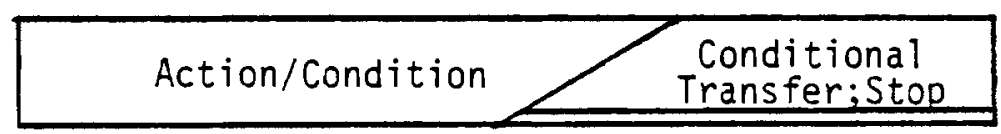

Abnormal Transfer

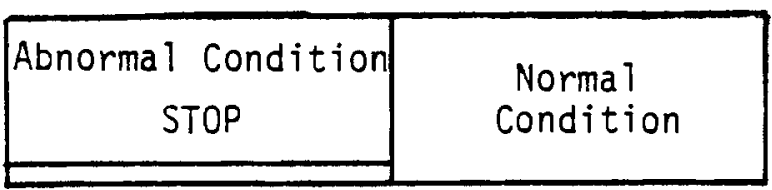

Abnormal Termination

FIGURE A.2-1. Chapin Chart Logic Constructs 
In addition to the general control function, ALLDOS defines dimensions of most data arrays used in the program. Also NAMELIST parameters are made available to subroutine call lists through inclusions of labeled common block ICOM. The logic structure of ALLDOS is indicated in Figure A.2-2.

\section{A.2.2 CASEIN}

This module controls input of data for one case and generation of release inventories by pathway (when requested). Common block ICOM and blank common are included in CASEIN. CASEIN calls subroutine EDORG to edit input organ selection parameters, ZEROI to initialize the integer array ISO and SOURCE to generate release inventories. The argument list parameters have the following uses:

\begin{tabular}{|c|c|c|}
\hline Parameter & Type & Description \\
\hline NUC & Integer & $\begin{array}{l}\text { Number of radionuclides in the master list from } \\
\text { File } 10\end{array}$ \\
\hline $\operatorname{REC}(100)$ & Character & Radionuclide names from the master list \\
\hline NORG & Integer & Number of organs defined in File 10 master list \\
\hline $\operatorname{IORG}(10)$ & Integer & Organ index values defined for File 10 organs \\
\hline TITLE ( 8 ) & Character & Descriptive title for this case \\
\hline JORG & Integer & Number of organs selected for this case \\
\hline $\operatorname{MORG}(10)$ & Integer & Organ cross-index values for selected organs \\
\hline$Q(5,100)$ & Real & $\begin{array}{l}\text { Activity (curies) of each radionuclide released } \\
\text { for each pathway }\end{array}$ \\
\hline ISO $(100)$ & Integer & $\begin{array}{l}\text { Control integer to indicate which master radio- } \\
\text { nuclides are included in the release term }\end{array}$ \\
\hline \multicolumn{3}{|c|}{$\begin{array}{l}\text { This module reads a case title card, a NAMELIST INPUT card set and con- } \\
\text { input of the inventory depending on the value of INV as follows: }\end{array}$} \\
\hline & $\leq 0$ & action; use previous inventory \\
\hline & 1 & ead release activities from cards \\
\hline & & $\begin{array}{l}\text { Cal1 SOURCE to generate new release } \\
\text { activities }\end{array}$ \\
\hline
\end{tabular}


FIGURE A.2-2 Logic Diagram for ALLDOS

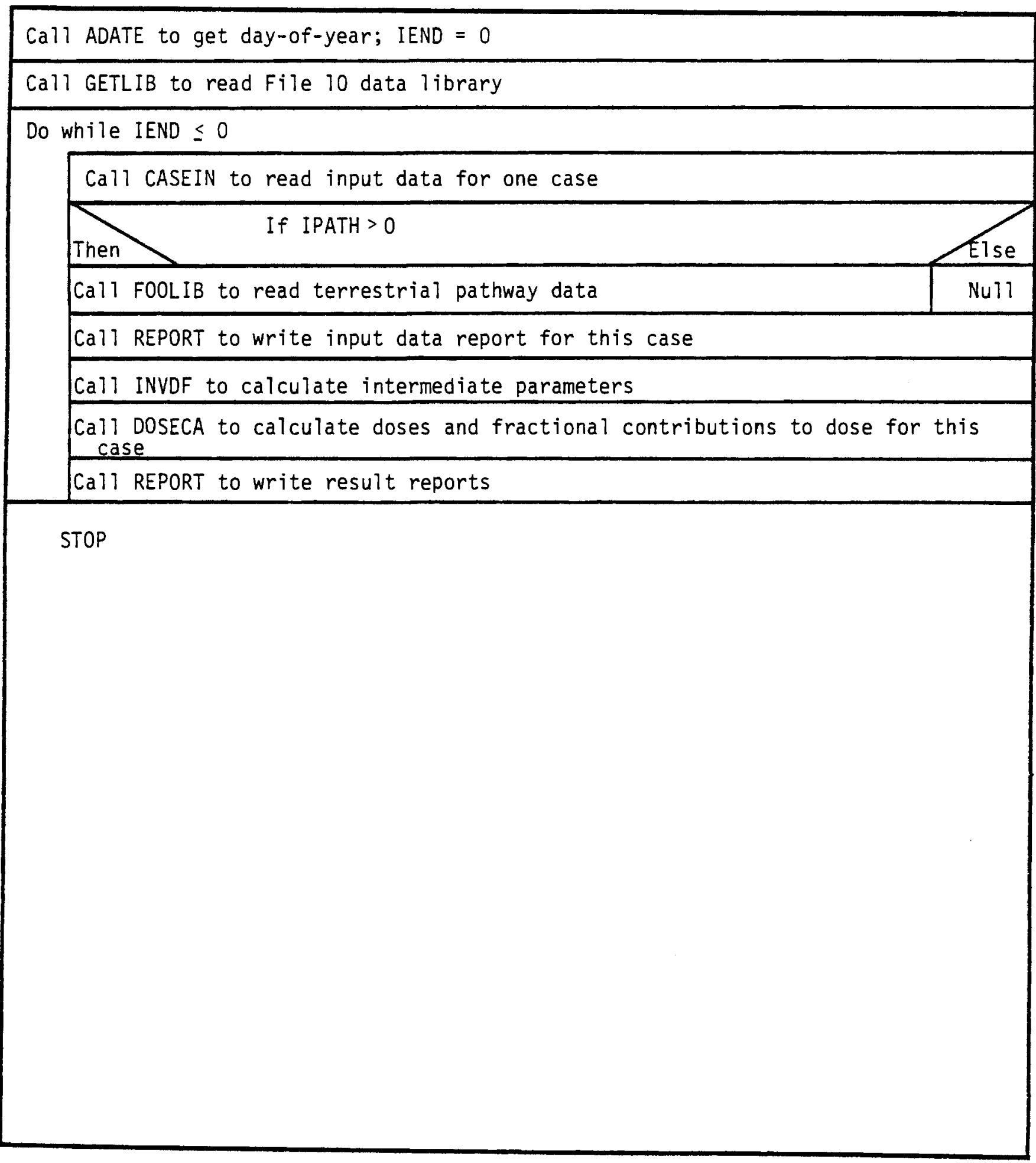


When INV = 1 cards are read giving release activities for each pathway. The parameter NREL is used to determine how many pathways are to be considered (maximum is three). The first pathway is for airborne releases for external and inhalation exposure; the second pathway is for airborne releases and terrestrial paths; and the last is for waterborne releases and terrestrial paths. Each input activity card has a radionuclide name indicating which radionuclide the activities on the card are to be assigned. This name is compared with the master radionuclide names (REC) until a match is found. If the input radionuclide name is not found, an error message is printed and execution is stopped.

The parameter IEND is set when an error condition is detected. Values of IEND set in CASEIN (and subroutines of CASEIN) are:

\begin{tabular}{ll} 
IEND Value & \multicolumn{1}{c}{ Error Condition } \\
\cline { 2 - 2 } 3 & $\begin{array}{l}\text { End-of-file encountered on attempt to read a } \\
\text { title card. This is the normal mode for } \\
\text { termination of the run. }\end{array}$ \\
& $\begin{array}{l}\text { An input organ index value, LORG }(N) \text {, is not } \\
\text { in the master organ list IORG. }\end{array}$ \\
5 & $\begin{array}{l}\text { End-of-file encountered on reading release } \\
\text { inventory cards (INV }=1) .\end{array}$ \\
& An input radionuclide name can not be found in \\
& the master list (INV $=1)$.
\end{tabular}

A logic diagram for CASEIN is given in Figure A.2-3.

\section{A.2.3 DFREAD}

This module reads a set of release factors from the card input file. The argument list parameter $\mathrm{DF}(80)$ is an array to transmit the input release factors back to the calling subroutine DFIN.

Release factors are read for one radionuclide class at a time as follows: 
FIGURE A.2-3 CASEIN Logic Diagram

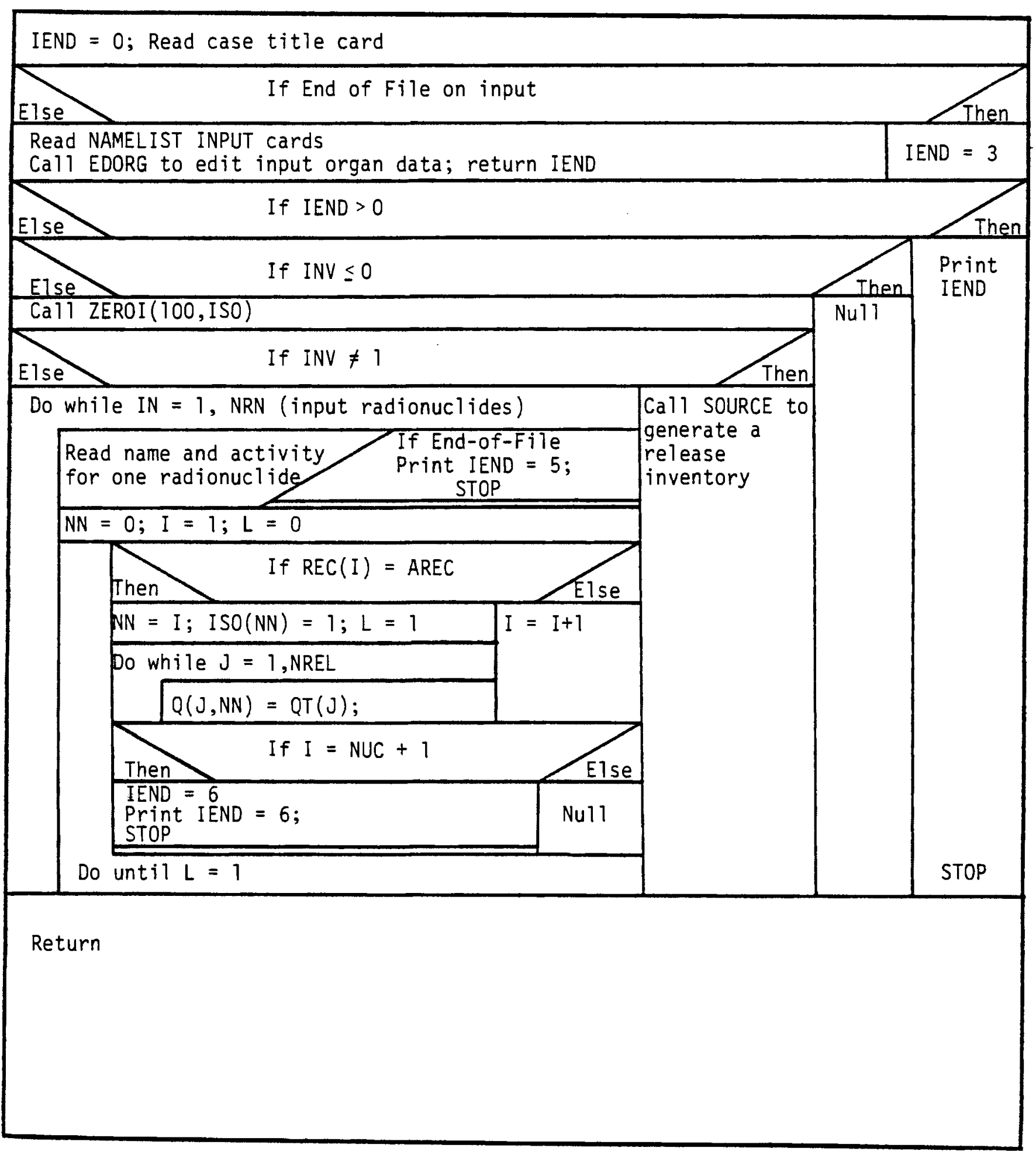




\begin{tabular}{|c|c|c|c|}
\hline Parameter & Columns & Format & Description \\
\hline IC & $1-2$ & I2 & $\begin{array}{l}\text { Radionuclide class for which the } \\
\text { accompanying release factor is to be } \\
\text { assigned } 1 \leq 1 \mathrm{C} \leq 80 \text {. Input of these } \\
\text { cards is terminated when IC }>80 \text {. }\end{array}$ \\
\hline$D F(I C)$ & $3-10$ & E8-1 & $\begin{array}{l}\text { Release factor for the radionuclide } \\
\text { class IC. }\end{array}$ \\
\hline
\end{tabular}

Cards of this type are read until a value for IC greater than 80 is read.

If an end-of-file is encountered, the error parameter IEND is set to 27 and the following message is printed: "End of file on DF input in DFREAD, IEND $=27 "$.

A logic diagram for DFREAD is given in Figure A.2-4.

\section{A.2.4 DFIN}

This module controls input of release factors for each of three release pathways. Subroutine DFREAD is called to read release factors from cards. The argument list parameters have the following uses:

\begin{tabular}{|c|c|c|}
\hline Parameter & Type & Description \\
\hline LADF & Integer & $\begin{array}{l}\text { Control integer for input of airborne } \\
\text { pathway release factors for inhalation } \\
\text { and external exposure }\end{array}$ \\
\hline LTDF & Integer & $\begin{array}{l}\text { Control integer for input of waterborne } \\
\text { pathway release factors }\end{array}$ \\
\hline LFDF & Integer & $\begin{array}{l}\text { Control integer for input of terrestrial } \\
\text { pathway release factors }\end{array}$ \\
\hline$A D F(80)$ & Real & $\begin{array}{l}\text { Airborne pathway release factors for } \\
\text { inhalation and external exposure by } \\
\text { radionuclide class }\end{array}$ \\
\hline $\operatorname{TDF}(80)$ & Real & $\begin{array}{l}\text { Waterborne pathway release factors by } \\
\text { radionuclide class }\end{array}$ \\
\hline $\operatorname{FDF}(80)$ & Rea 1 & $\begin{array}{l}\text { Terrestrial pathway release factors by } \\
\text { radionuclide class }\end{array}$ \\
\hline
\end{tabular}




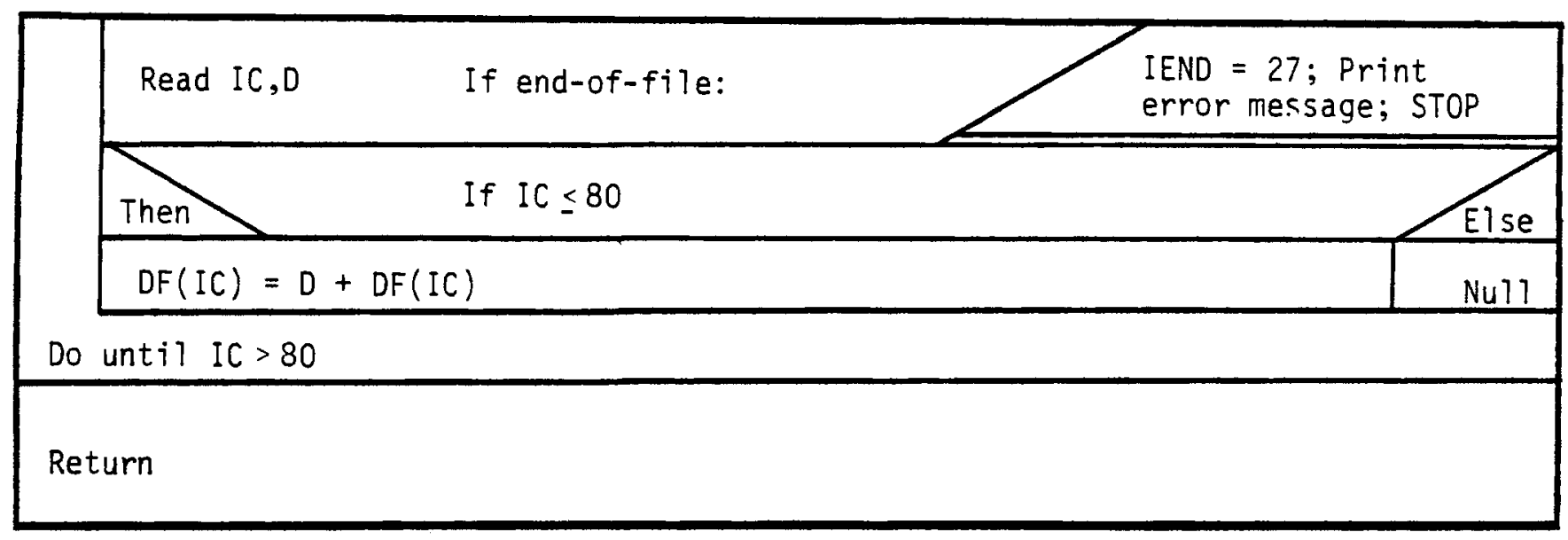

FIGURE A.2-4 DFREAD Logic Program 
When any of the pathway control integers is equal to 2, a card is read giving the maximum number of radionuclide classes to be considered. This parameter (NCL) should correspond to NCLS read in subroutine SQIN and must not be greater than 80 . NCL is only used to initialize the release factor arrays to zero (ADF, TDF and FDF). Release factors are read for a pathway whenever the control integer for the pathway is greater than zero. The order of input is:

- $A D F$ (if LADF >0) - Airborne pathway

- TDF (if LTDF >0) - Waterborne pathway

- FDF (if LFDF >0) - Terrestrial pathway

A logic diagram for subroutine DFIN is given in Figure A.2-5.

\section{A.2.5 EDORG}

This module checks input organ indices against File 10 organ indices and prints an error message when an invalid input index is found. The number of nonzero organ index values is counted and saved as JORG. The cross-index parameter array MORG(5) is established. The value for MORG(I) is set to the position of input organ $I$ in the master organ array IORG(5).

The argument list parameters have the following uses:

\begin{tabular}{|c|c|c|}
\hline Parameter & Type & Description \\
\hline NORG & Integer & Number of organs defined in File 10 master list \\
\hline IORG (10) & Integer & Organ index values defined for File 10 organs \\
\hline $\operatorname{LORG}(5)$ & Integer & Input organ index values \\
\hline MORG (5) & Integer & Organ cross-index array for selected organs \\
\hline JORG & Integer & Number of organs specified on input \\
\hline IEND & Integer & $\begin{array}{l}\text { Error flag set to } 4 \text { if a bad organ index is } \\
\text { found }\end{array}$ \\
\hline
\end{tabular}

If one of the input organ index values is not found in the master organ index array IORG, then an error message is printed indicating which organ index is in error. The message is:

Organ ID "N" not found.

The logic diagram for EDORG is given in Figure A.2-6. 


\begin{tabular}{|l|l|}
\hline If $L A D F=2$ or $L T D F=2$ or LFDF $=2$ \\
\hline Read $N C L$ (number of classes)
\end{tabular}

FIGURE A.2-5 DFIN Logic Diagram 
FIGURE A.2-6 EDORG Logic Diagram

$J O R G=0$

Call ZEROI (5, MORG)

Do while $\mathrm{N}=1,5$ and IEND $=0$

If $\operatorname{LORG}(\mathrm{N}) \leq 0$

ID $=0$

Nul1

Do while $M=1$, NORG (1 ibrary organ 1ist)

Then If $\operatorname{LORG}(\mathrm{N})=\operatorname{IORG}(\mathrm{M})$

JORG $=J O R G+1$

MORG $(J O R G)=M$

ID $=1$

IEND $=4$
Print "Organ ID", N, "Not Found"

Else

Nu1 1

Return 


\section{A.2.6 SOURCE}

This module generates release inventories for each of the three release pathways. The parameter INV is used to indicate the method for calculating the release inventories. (INV is always greater than 1 when SOURCE is called.)

Common block TITLE and blank common are included in SOURCE. Module DFIN is called by SOURCE to supply release factors for each pathway. Module SQIN is called to provide the basic radionuclide inventory and module ZEROR is called to initialize array $Q$ to zero. System routine ADATE is called to generate an 8 character day-of-year title.

The argument list parameters have the following uses:

\begin{tabular}{|c|c|c|}
\hline Parameter & Type & Description \\
\hline NUC & Integer & $\begin{array}{l}\text { Number of radionuclides in the master list from } \\
\text { File } 10\end{array}$ \\
\hline $\operatorname{REC}(100)$ & Character & Radionuclide names from the master 1 ist \\
\hline ISO (100) & Integer & $\begin{array}{l}\text { Control integer to indicate which master list } \\
\text { radionuclides are included in the release term }\end{array}$ \\
\hline INV & Integer & $\begin{array}{l}\text { Control integer for generation of the release } \\
\text { inventory }\end{array}$ \\
\hline LADF & Integer & $\begin{array}{l}\text { Control integer for input of airborne pathway } \\
\text { release factors }\end{array}$ \\
\hline LTDF & Integer & $\begin{array}{l}\text { Control integer for input of waterborne } \\
\text { pathway release factors }\end{array}$ \\
\hline LFDF & Integer & $\begin{array}{l}\text { Control integer for input of terrestrial pathway } \\
\text { release factors }\end{array}$ \\
\hline TITLE (8) & Character & Case title \\
\hline$Q(5,100)$ & Real & Release inventory array \\
\hline
\end{tabular}


If any of the control integers LADF, LTDF or LFDF are positive, then subroutine DFIN is called to read in release factor data for necessary pathways. The parameter TONS is set to 1.0 if it has not been set on NAMELIST INPUT. This parameter is used to modify external and inhalation dose factors when releases last more than one year. (See module DOSECA.)

Subroutine SQIN is called only if INV is not equal to 2 . When INV is 2, the previous bas is inventory is used with current release factors for each pathway to generate the release inventory. The release inventory is generated as :

$$
Q_{i j}=Q_{0 i} D_{f i j}
$$

where

$Q_{i j}$ - activity of radionuclide $i$ released for pathway $j$, curies

$Q_{0 i}$ - activity of radionuclide $i$ in the basic inventory, curies

$D_{f i j}$ - fraction of basic inventory of radionuclide $i$ released to pathway $j$.

The release fractions are defined for each pathway and each radionuclide class as follows:

Parameter Description

$\operatorname{ADF}[\operatorname{ICL}(i)] \quad$ Fraction of radionuclide $i$ released to the airborne pathway

$\operatorname{TDF}[\operatorname{ICL}(i)]$ Fraction of radionuclide $i$ released to the waterborne pathway

FDF $[I C L(i)] \quad$ Fraction of radionuclide $i$ released to the terrestrial pathway

ICL(i) Radionuclide class index for radionuclide $i$.

This array is defined by input in subroutine SQIN

$\mathrm{SQ}(\mathrm{n}) \quad$ Activity of radionuclide $n$ in basic inventory

Note: $\mathrm{n}$ does not correspond to $i$. 
The input basic inventory radionuclides are identified by the radionuclide name array $A Q$. Each input inventory radionuclide name is compared to the master list names of array REC to set array index values. If a match is not found, an error message is printed and execution is stopped. The error message is:

"Unidentified nuclide number II Name"

Note that one radionuclide may appear more than once in the basic inventory and with different class index values. This allows multiple sources for one radionuclide to be added to get the total release for a pathway.

A logic diagram for subroutine SOURCE is given in Figure A.2-7. 


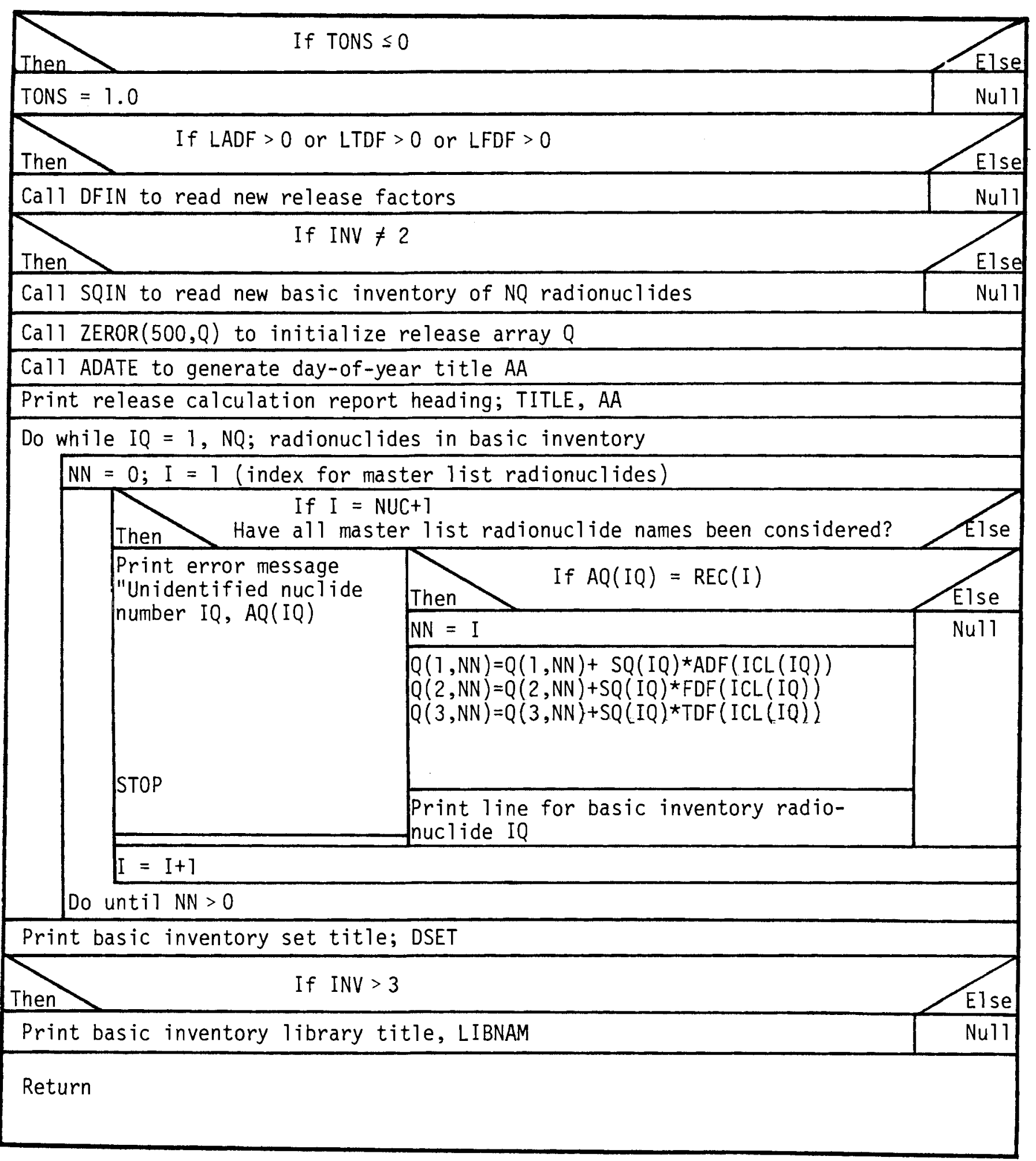




\section{A.2.7 SQIN}

This module controls reading of the basic radionuclide inventory from cards (INV $=3$ ) or File 15 (INV > 3). Common block TITLE is included in SQIN. The argument list parameters have the following uses:

\begin{tabular}{|c|c|c|}
\hline Parameter & Type & Description \\
\hline INV & Integer & $\begin{array}{l}\text { Control integer for input of the basic } \\
\text { radionuclide inventory }\end{array}$ \\
\hline NQ & Integer & $\begin{array}{l}\text { Number of radionuclides in the basic radio- } \\
\text { nuclide inventory }\end{array}$ \\
\hline$S Q(350)$ & Real & $\begin{array}{l}\text { Activity of each radionuclide in the basic } \\
\text { inventory, curies }\end{array}$ \\
\hline$A Q(350)$ & Character & $\begin{array}{l}\text { Names of each radionuclide in the basic } \\
\text { inventory }\end{array}$ \\
\hline $\operatorname{ICL}(350)$ & Integer & $\begin{array}{l}\text { Radionuclide class for each radionuclide } \\
\text { in the basic inventory }\end{array}$ \\
\hline $\operatorname{DFNAM}(80)$ & Character & Title for each radionuclide class \\
\hline $\operatorname{LIBNAM}(7)$ & Character & Title of the File 15 data library \\
\hline $\begin{array}{l}\text { When INV }= \\
\text { ows: }\end{array}$ & the basic inve & tory information is read from cards as \\
\hline Card Type & Parameter & Description \\
\hline 1 & $\begin{array}{l}\text { NQ } \\
\operatorname{DSET}(5)\end{array}$ & $\begin{array}{l}\text { Number of radionuclides in the basic inventory } \\
\text { Title for this basic inventory }\end{array}$ \\
\hline 2 & NCLS & $\begin{array}{l}\text { Number of radionuclide classes to be considered } \\
\text { in this basic inventory }\end{array}$ \\
\hline 3 & ICLS & Index of current class \\
\hline & DFNAM(ICLS) & $\begin{array}{l}\text { Name of current class (Read NCLS of these } \\
\text { cards) }\end{array}$ \\
\hline 4 & $A Q(i)$ & Name of current radionuclide \\
\hline & $\operatorname{ICL}(i)$ & Class of current radionuclide \\
\hline & $S Q(i)$ & $\begin{array}{l}\text { Activity of current radionuclide (Read NQ of } \\
\text { these cards) }\end{array}$ \\
\hline
\end{tabular}


When INV is greater than 3, input of the basic inventory is from the File 15 data library. This library contains NSETS basic inventory sets (see card descriptions below). The value of INV-3 gives the set to be used as the basic inventory for this case. The first data card in the basic inventory data library is as follows:

$\frac{\text { Card Type }}{1} \quad \frac{\text { Parameter }}{\text { NSETS }}$

Description

Number of basic inventory sets in this data library

LIBNAM Title of this data library

The radionuclide class cards (same as types 2 and 3 above) follow the first card. These classes are defined for all data sets in this library. The remaining cards are given for each inventory set as described for card input data sets (INV = 3) given above for card types 1 and 4 .

When input is from File 15 , the file is rewound after being read because subsequent cases may also access the file.

Three error messages are generated by SQIN. When the value of INV-3 is not in the range of 1 to NSETS an error message is printed as follows:

"Inventory not found (NSETS) set in library. ISET = ISET). When an end-of-file is encountered on the card input file the following message is printed:

"End of file on input, IEND $=29 "$

When an end-of-file is encountered on File 15 the following message is printed:

"End of file on source, IEND = 30"

Execution is stopped when any of these errors is detected.

A logic diagram for subroutine SQIN is given in Figure A.2-8. 
FIGURE A.2-8 SQIN Logic Diagram

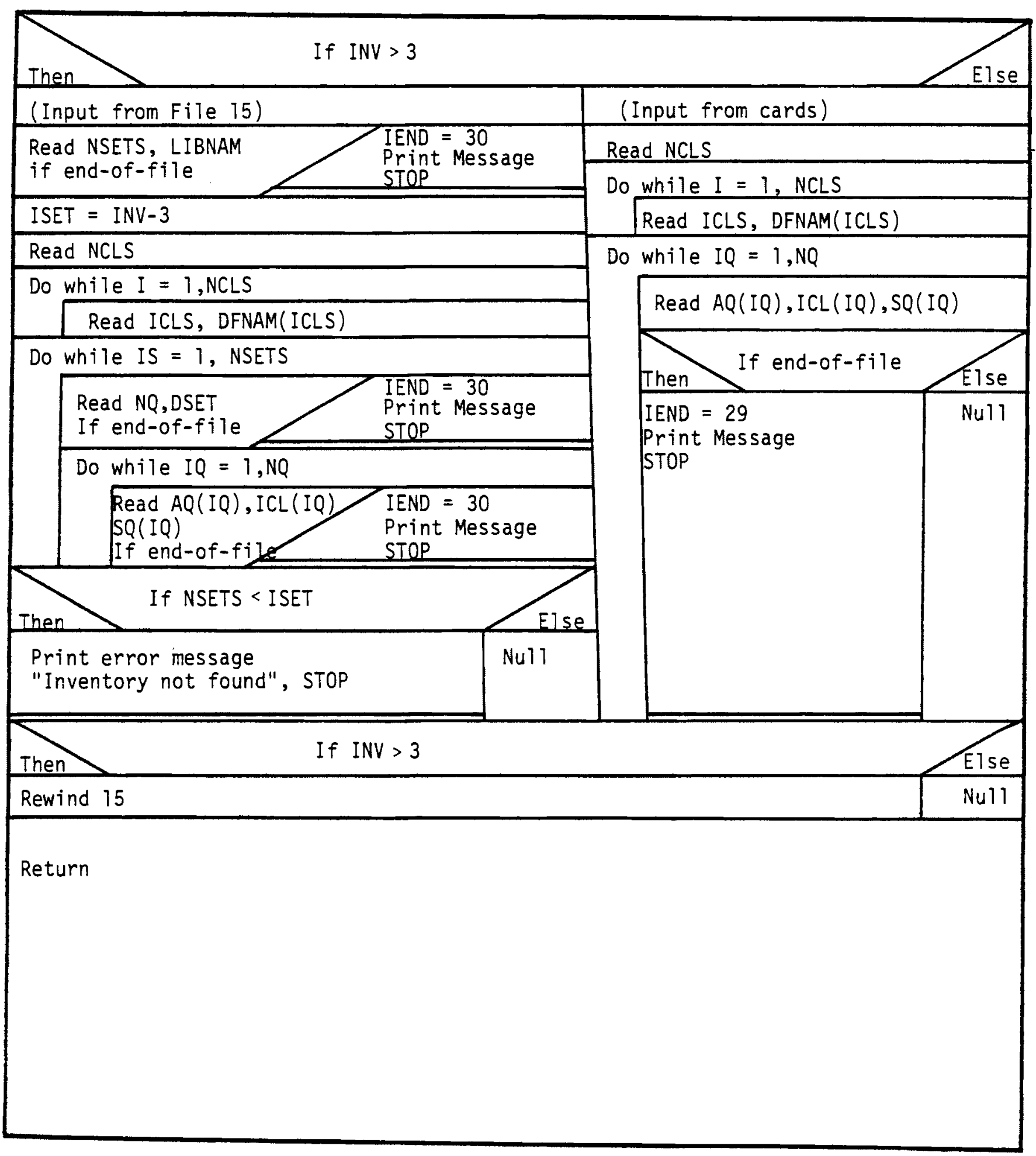


APPENDIX B

DATA LIBRARIES 


\section{APPENDIX B}

\section{DATA LIBRARIES}

The code ALLDOS uses two data libraries to provide dose conversion factors plus a third optional library for basic inventory data. The data libraries used by ALLDOS are:

File 10 - Radionuclide identification plus external and inhalation dose conversion factor data library.

File 12 - Terrestrial pathway dose conversion factor data library.

File 15 - Radionuclide inventory data library.

The following sections describe each data file.

\section{B.1 File 10 - Radionuclide Ident ification/Dose Conversion Factors}

This data library contains master radionuclide identification symbols, organ identification parameters and dose conversion factor data for external exposure and inhalation uptake. The first card image of the library contains the following information:

\begin{tabular}{|c|c|c|c|}
\hline Parameter & Columns & Format & Description \\
\hline NUC & $1-5$ & I5 & $\begin{array}{l}\text { Number of radionuclides for which } \\
\text { data will be supplied in this } \\
\text { library, } 1 \leq \text { NUC } \leq 100 \text {. }\end{array}$ \\
\hline NORG & $6-10$ & I5 & $\begin{array}{l}\text { Number of organs for which data is } \\
\text { supplied in this library, } 1 \leq N O R G \leq 10 \text {. }\end{array}$ \\
\hline$N T^{\star}$ & $11-15$ & I5 & $\begin{array}{l}\text { Number of dose times for which data } \\
\text { is supplied in this library, } 1 \leq N T \leq 2 \text {. }\end{array}$ \\
\hline$N R$ * & $16-20$ & I5 & $\begin{array}{l}\text { Number of release modes to be } \\
\text { considered (i.e., acute, chronic), } \\
1 \leq N T \leq 3 \text {. }\end{array}$ \\
\hline $\operatorname{IORG}(10)$ & $\begin{array}{l}21-23 \\
24-26 \\
\vdots \\
48-50\end{array}$ & $10 I 3$ & $\begin{array}{l}\text { Organ index values for each organ } \\
\text { that data will be provided for, } \\
1 \leq \operatorname{IORG}(i) \leq 23 \text {. }\end{array}$ \\
\hline
\end{tabular}

\footnotetext{
* The parameters NT and NR are not currently used by the program.
} 
Values for organ indices are used to identify requested organs for each run through the imput parameter LORG(10). A suggested organ index list is given in Table B.1-1.

The second card contains an 80 character descriptive title to be printed on an output report to indicate which version of this data library was accessed. Each version should therefore have a unique title.

The third card (and fourth if necessary) gives titles for organs that data will be supplied for. Ten characters are allowed for each organ with eight organ names per card (format $8 \mathrm{AlO}$ ). If more than 8 organs are specified $(9 \leq N O R G \leq 10)$ then an additional card is read. The names are stored in array ONAME (10). The organ index values and the organ names should correspond by position; i.e., IORG( $i)$ is the index for ONAME $(i)$. (See suggested organs in Table B.1-1.)

After the last organ name card a card is read giving dose commitment period information as follows:

\begin{tabular}{|c|c|c|c|}
\hline Parameter & Columns & Format & Description \\
\hline IDTIME (1) & $1-5$ & I5 & $\begin{array}{l}\text { Dose commitment time for lst period } \\
\text { for acute and chronic uptake, years } \\
\text { (integer value). }\end{array}$ \\
\hline IDT IME (2) & $6-10$ & I5 & $\begin{array}{l}\text { Dose commitment time for } 2 \text { nd period } \\
\text { for acute and chronic uptake, years } \\
\text { (integer value). }\end{array}$ \\
\hline IDTIME (3) & $11-15$ & 15 & $\begin{array}{l}\text { Dose commitment time to be used for } \\
\text { acute and chronic releases (prolonged) } \\
\text { when the parameter } L Y=3 \text {, years } \\
\text { (integer value). }\end{array}$ \\
\hline IDTIME (4) & $16-20$ & 15 & $\begin{array}{l}\text { Uptake period (plant life) for } \\
\text { prolonged releases, years (integer } \\
\text { value). }\end{array}$ \\
\hline
\end{tabular}


TABLE B.1-1 Suggested Organ Index List

\begin{tabular}{|c|c|}
\hline Organ of Reference & Index Value \\
\hline Total body & 1 * \\
\hline Adrenals & 9 \\
\hline Bone & $6 *$ \\
\hline Brain & 13 \\
\hline Fat & 7 \\
\hline \multicolumn{2}{|l|}{ GI Tract } \\
\hline Stomach & 20 \\
\hline Small intestine & 21 \\
\hline Upper large intestine & 22 \\
\hline Lower large intestine & 23 \\
\hline Heart & 18 \\
\hline Kidneys & $3^{*}$ \\
\hline Liver & $4 *$ \\
\hline Lungs & $8^{\star}$ \\
\hline Muscle & 14 \\
\hline Ovaries & 11 \\
\hline Pancreas & 17 \\
\hline Prostate & 15 \\
\hline Skin & 12 \\
\hline Spleen & 5 \\
\hline Testes & 10 \\
\hline Thyroid & $16^{\star}$ \\
\hline
\end{tabular}

* These organs are included in the current version of the data library (see Appendix C listing). 
The remainder of the library contains dose conversion factor data for each radionuclide (NUC total radionuclides). The first card for each radionuclide contains radionuclide identification symbols, an external dose conversion factor and a control parameter to indicate if inhalation data will be provided for the radionuclide. The data is as follows:

$\begin{array}{llll}\text { Parameter } & \text { Columns } & \text { Format } & \end{array}$

ALLDOS uses only the $5 \mathrm{~cm}$ external dose conversion factor, $\operatorname{EXDF}(1, i)$. When the control parameter $L O$ is positive additional cards are read for this radionuclide. Each additional card contains inhalation dose conversion factors for one organ as follows: 


$\begin{array}{llll}\text { Parameter } & \text { Columns } & \text { Format } & \end{array}$

The exposure types are defined for specific uptake periods and dose commitment periods as indicated in Table B.1-2. The acute uptake dose conversion factors are based on an inhalation ventilation rate of $3.5 \times 10^{-4} \mathrm{~m}^{3}$ per sec while

TABLE B.1-2 Inhalation Exposure Types

\begin{tabular}{|c|c|c|}
\hline $\begin{array}{c}\text { Exposure } \\
\text { Type } \\
\text { Index } \\
\end{array}$ & $\begin{array}{l}\text { Uptake } \\
\text { Period }\end{array}$ & $\begin{array}{c}\text { Dose } \\
\text { Commitment } \\
\text { Period* } \\
\end{array}$ \\
\hline 1 & Acute & 1 year \\
\hline 2 & Acute & 50 years \\
\hline 3 & 1 year & 0 \\
\hline 4 & 1 year & 49 years \\
\hline 5 & 30 yuears & 40 years \\
\hline
\end{tabular}

* Measured from the end of the uptake period. 
the other factors are based on a rate of $2.3 \times 10^{-4} \mathrm{~m}^{3} / \mathrm{sec}$. The inhalation dose conversion factors have units of rem per $\left(\mathrm{Ci} \cdot \mathrm{sec} / \mathrm{m}^{3}\right)$ for the organ of interest.

\section{B.2 File 12 - Terrestrial Pathway Dose Conversion Factor Data Library}

This library contains dose conversion factors for terrestrial pathways representative of the site of interest. Because these factors are dependent on site specific parameters this data library must be developed for each site to be studied. The preparation of the dat library is discussed in Section E.2.1. The first card of the library gives the number of radionuclides (NISO) for which data will be supplied plus a descriptive title which is printed immediately. The format of this card is I5, 7A10.

The data library contains sixteen sets of data as described in Table B.2-1. The

first card of each set contains a control parameter (NI) and a descriptive title. The format is $15,7 \mathrm{Al}$. A zero value for NI causes reading of this data library to stop; otherwise all 16 sets are read. The terrestrial pathway dose conversion factors are read next with each card containing data for one radionuclide. These cards contain the following information:

\section{TABLE B.2-1 Terrestrial Pathway Data Sets}

\begin{tabular}{|c|c|c|c|c|}
\hline $\begin{array}{c}\text { Set } \\
\text { Number }\end{array}$ & $\begin{array}{l}\text { Exposed } \\
\text { Group }\end{array}$ & $\begin{array}{c}\text { Release } \\
\text { Mode }\end{array}$ & $\begin{array}{l}\text { Release } \\
\text { Type }\end{array}$ & $\begin{array}{l}\text { Dose } \\
\text { Commitment Period* }\end{array}$ \\
\hline 1 & Maximum individual & Air & Acute & Period 1 \\
\hline 2 & Maximum individual & Air & Acute & Period 2 \\
\hline 3 & Population & Air & Acute & Period 1 \\
\hline 4 & Population & Air & Acute & Period 2 \\
\hline 5 & Maximum individual & Water & Acute & Period 1 \\
\hline 6 & Maximum individual & Water & Acute & Period 2 \\
\hline 7 & Population & Water & Acute & Period 1 \\
\hline 8 & Population & Water & Acute & Period 2 \\
\hline 9 & Maximum individual & Air & Chronic & Period 1 \\
\hline 10 & Maximum individual & Air & Chronic & Period 2 \\
\hline 11 & Population & Air & Chronic & Period 1 \\
\hline 12 & Population & Air & Chronic & Period 1 \\
\hline 13 & Maximum individual & Water & Chronic & Period 1 \\
\hline 14 & Maximum individual & Water & Chronic & Period 2 \\
\hline 15 & Population & Water & Chronic & Period 1 \\
\hline 16 & Population & Water & Chronic & Period 2 \\
\hline
\end{tabular}

Dose commitment periods are defined by the user. 


\begin{tabular}{|c|c|c|c|}
\hline Parameter & Columns & Format & Description \\
\hline $\operatorname{RIN}(i)$ & $1-7$ & A7 & $\begin{array}{l}\text { Radionuclide identification symbol. } \\
\text { This symbol must match the symbol for } \\
\text { this radionuclide as given in the } \\
\text { File } 10 \text { library. If a match is not } \\
\text { found, data for the radionuclide is } \\
\text { ignored. }\end{array}$ \\
\hline - & 8 & $1 x$ & Blank \\
\hline$D F(j)$ & $\begin{array}{c}9-18 \\
19-28 \\
\vdots \\
49-58\end{array}$ & $5 E 10.2$ & $\begin{array}{l}\text { Dose conversion factors for five } \\
\text { organs for this radionuclide and data } \\
\text { set. The organs must be the same as } \\
\text { those specified on input cards for } \\
\text { all runs this library is used with. }\end{array}$ \\
\hline
\end{tabular}

When the first data set is read, the RIN parameter is compared with the File 10 input parameter REC to establish a cross index array for the two libraries. For the remainder of the sets the input symbol is compared to the RIN values from the first set. If a miss-match occurs (i.e., if the i-th card does not have RIN( $i)$ as its symbol) then an error message is printed and execution is stopped.

Care must be taken to coordinate organs selected on input cards with those for which data is available here. The two organ lists must correspond exact 1y.

The acute release dose factors have units of rem per $\mathrm{C} i$ released to the environment for each organ. The chronic release dose factors have units of rem per $\mathrm{Ci} /$ year released for each organ. If the chronic release period is $N$ years then the total release is $N$ curies. This is in contrast to the external and inhalation dose factors which are based on a total release of 1 curie over the uptake period.

\section{B.3 File 15 - Radionuclide Inventory Data Library}

This data library is used to supply radionuclide inventory activities for calculation of releases in conjunction with release factors (DF values). The 
library is only read when the input inventory specification control parameter (INV) is greater than 3 .

The organization of the library is:

- title card

- radionuclide class definition

- inventory sets

The title card contains the number of sets (NSETS) of inventory cards to be provided plus a descriptive title for the library. The format is $13,7 X, 7 A 10$. The number of sets must be greater than zero. The radionuclid class identification cards are as follows:

\section{Parameter Columns Format}

Description

Card 1

NCLS

$1-3$

I3

Number of classes to be defined. $1 \leq N C L S \leq 80$.

Cards $2+$

ICLS

$1-3$

I3

Class number being defined by this

$-$

4-10

$7 X$ card. $1 \leq \mathrm{ICLS} \leq 80$.

DFNAM( ICLS) $11-20$

A10

Blank

Descriptive title for this

radionuclide class.

The radionuclide classes defined on these cards are used in specifying the radionuclide inventory sets that follow and in specifying the release fractions used to generate the release inventories (see Appendix $D$ on input preparation). the user must coordinate definition and use of the radionuclide classes.

The inventory sets are composed of a title card and one card for each radionuclide as follows: 
Parameter Columns Format

Description

\begin{tabular}{|c|c|c|c|}
\hline NQ & $1-3$ & I3 & $\begin{array}{l}\text { Number of radionuclide cards to } \\
\text { follow. }\end{array}$ \\
\hline- & $4-10$ & $7 x$ & Blank \\
\hline $\operatorname{DSET}(5)$ & $11-60$ & $5 A 10$ & Title for this inventory set. \\
\hline \multicolumn{4}{|c|}{ Cards $2+($ NQ total) } \\
\hline$A Q(i)$ & $1-8$ & A8 & $\begin{array}{l}\text { Radionuclide identification } \\
\text { corresponding to a radionuclide } \\
\text { symbol (REC) in the File } 10 \text { data } \\
\text { library. }\end{array}$ \\
\hline ICL ( i ) & $9-10$ & I2 & $\begin{array}{l}\text { Index of the radionuclide class } \\
\text { assigned to this radionuclide. ICL } \\
\text { should correspond to one of the } \\
\text { values submitted for ICLS in the } \\
\text { class definition cards above. }\end{array}$ \\
\hline $\mathrm{SQ}(i)$ & $11-20$ & E10.1 & $\begin{array}{l}\text { Activity of this radionuclide in the } \\
\text { current inventory set, curies. }\end{array}$ \\
\hline
\end{tabular}

B. 9 


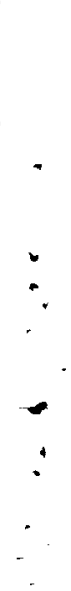




\section{APPENDIX C}

PROGRAM AND DATA LIBRARY LISTINGS 
APPENDIX C

\section{PROGRAM AND DATA LIBRARY LISTINGS}

This appendix presents listings of the computer program ALLDOS and two data libraries as follows:

Figure C.0-1 - Program Listing

Figure C.0-2 - File 10, Data Library

Figure C.0-3 - File 12, Data Library

A File 15 data library is not shown here because that library is optional and is to be provided by the user. Appendix $E$ provides a sample file 15 library for use with the sample problem. 


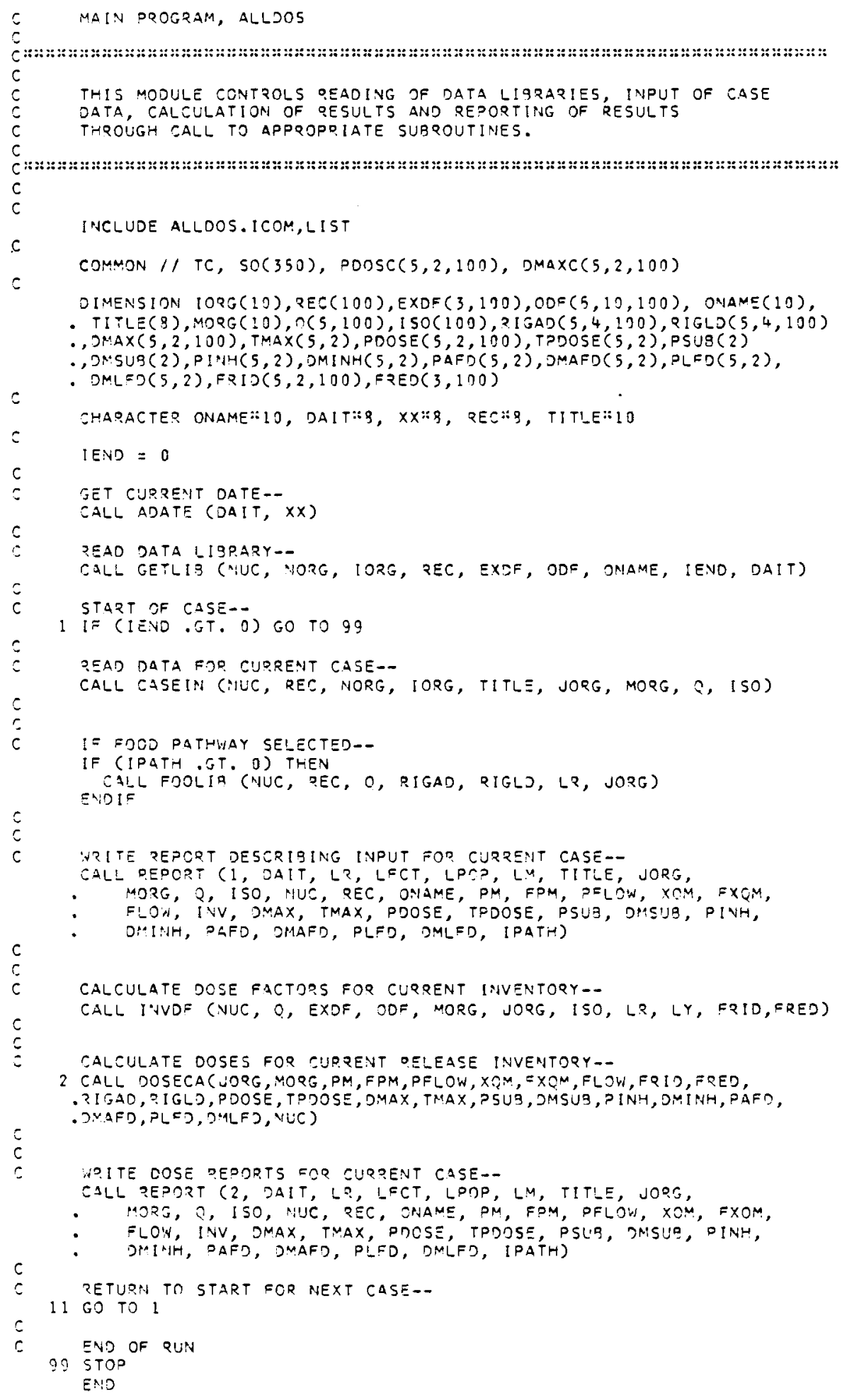

FIGURE C.0-1. Program Listing 
MODULE CASEIN

SUBROUTINE CASEIN(NUC, REC, NORG, IORG, TITLE, JORG, MORG, O, ISO)

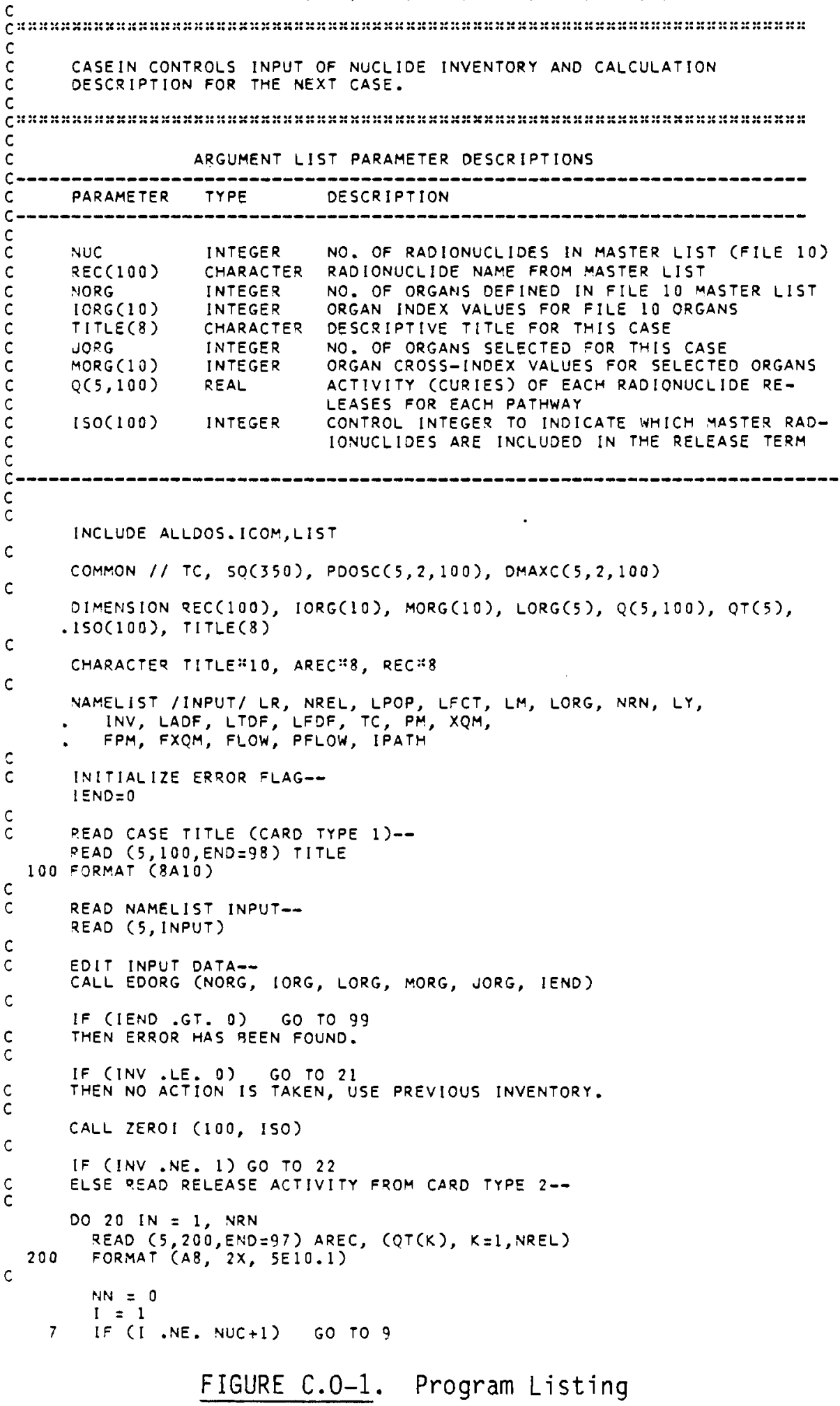

C. 3 
MODULE CASEIN

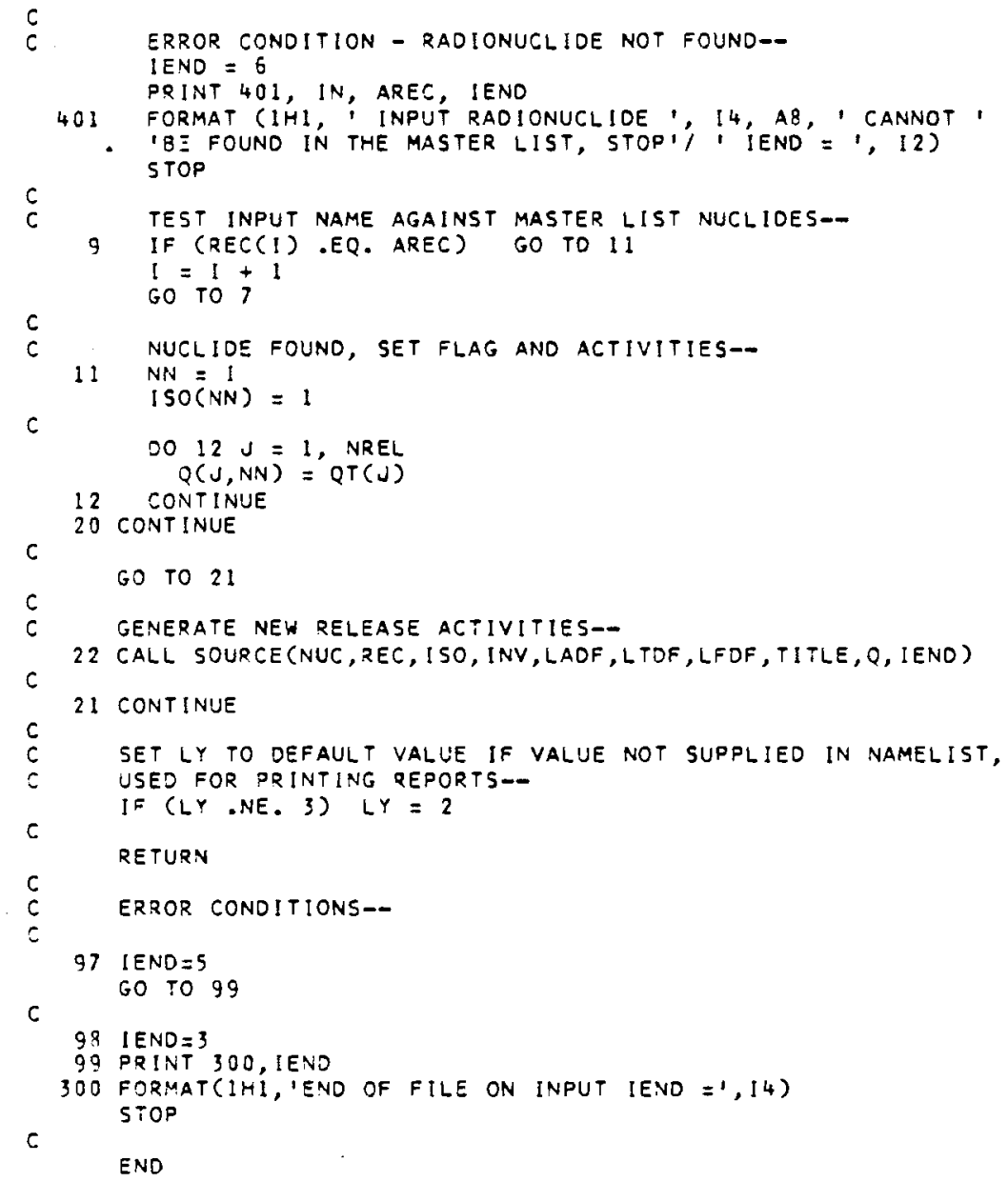

FIGURE C.0 - . Program Listing 


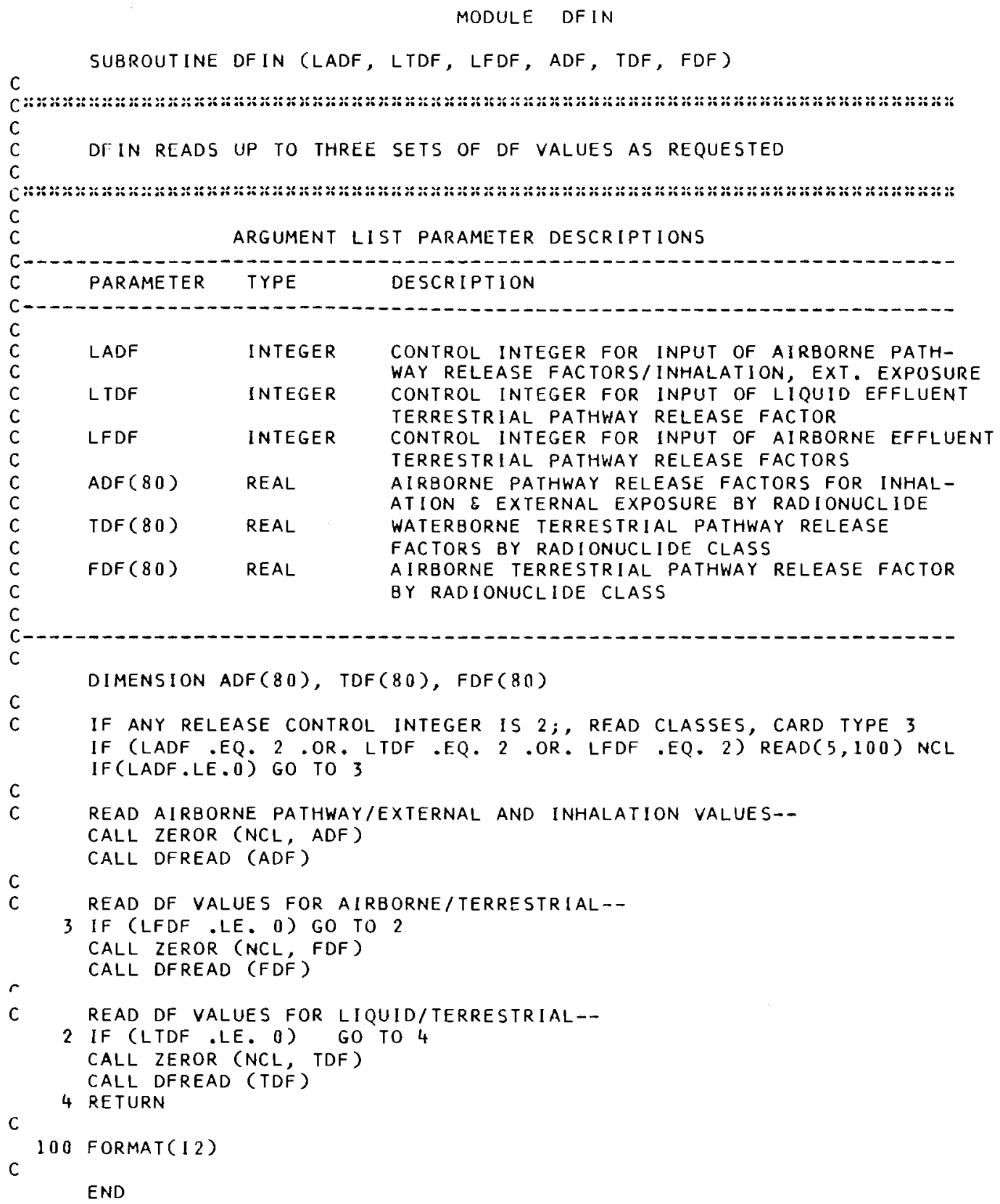

\section{FIGURE C.0-1. Program Listing}


SUBROUTINE DFREAD (DF)

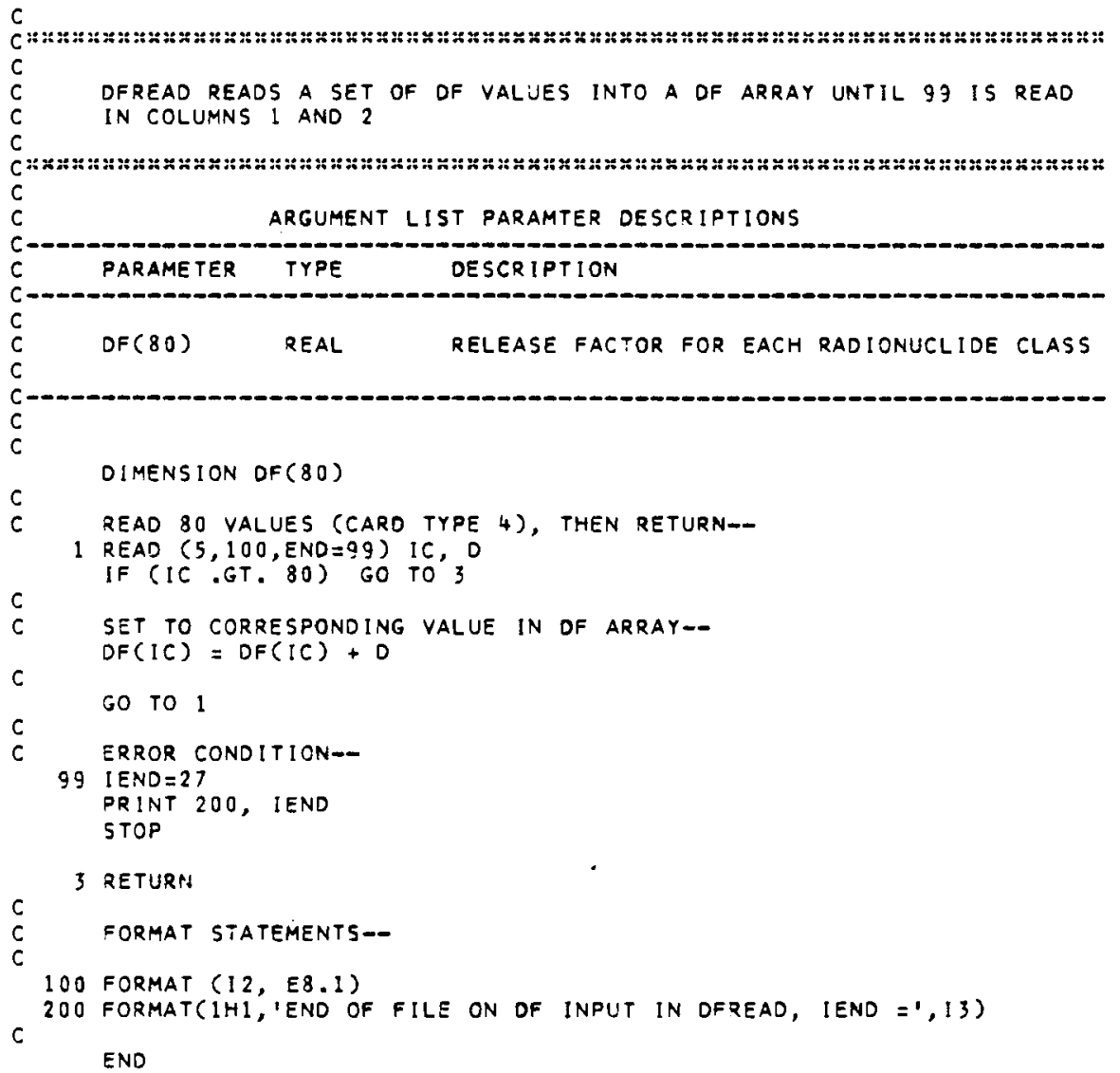

FIGURE C.0-1. Program Listing 
SURROUT INE DOSECA ( JORG, MORG, PM, FPM, PFLOW, XQM, FXQM, FLOW, FRID, FRED, - R IGAD, R IGLD, PDOSE, TPDOSE, DMAX, TMAX, PSUB, DMSUB, PINH, DMINH, PAFD, - DMAFD, PLFD, DMLFD, NUC

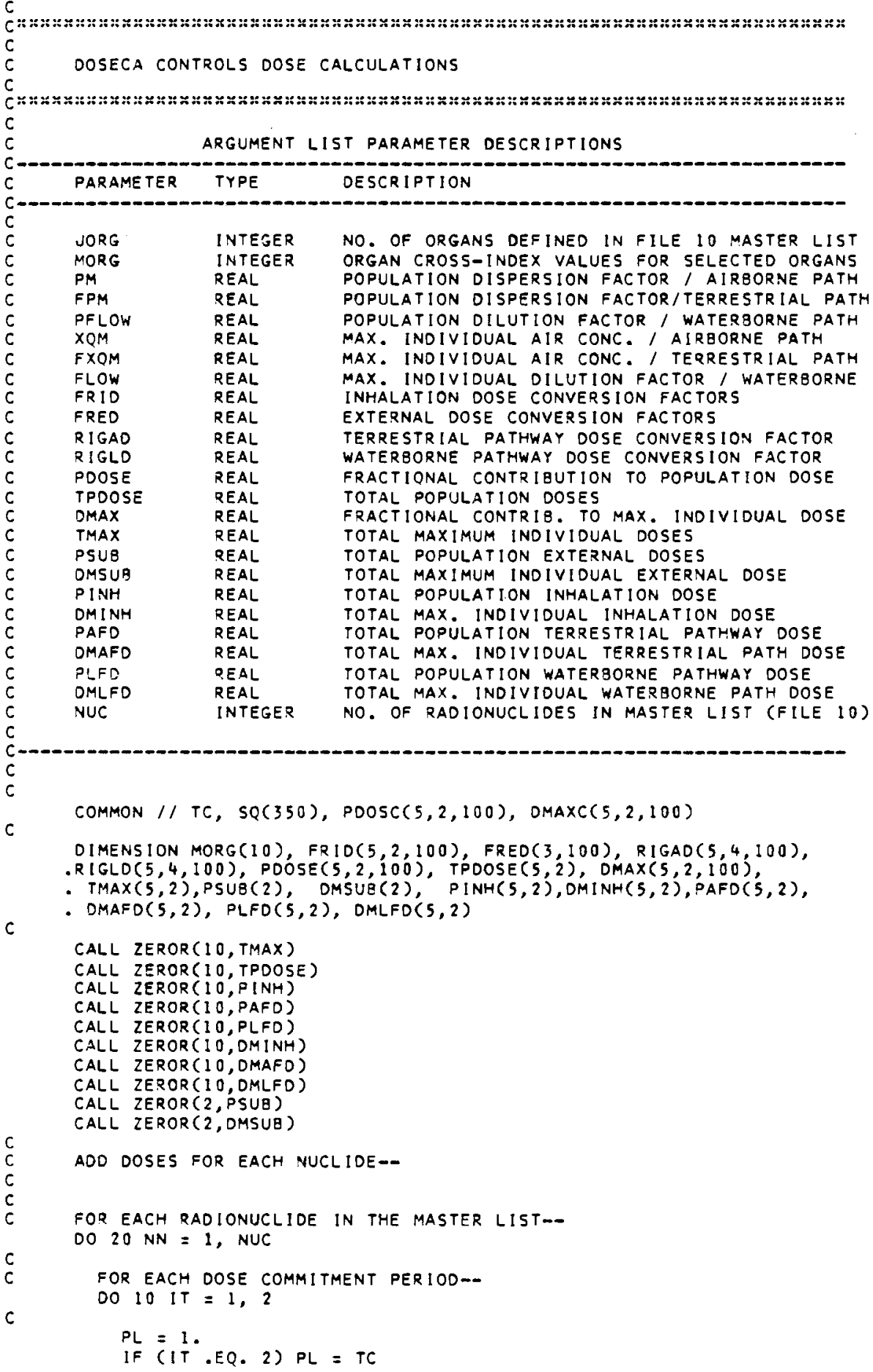

$c$

FIGURE C.0-1. Program Listing 


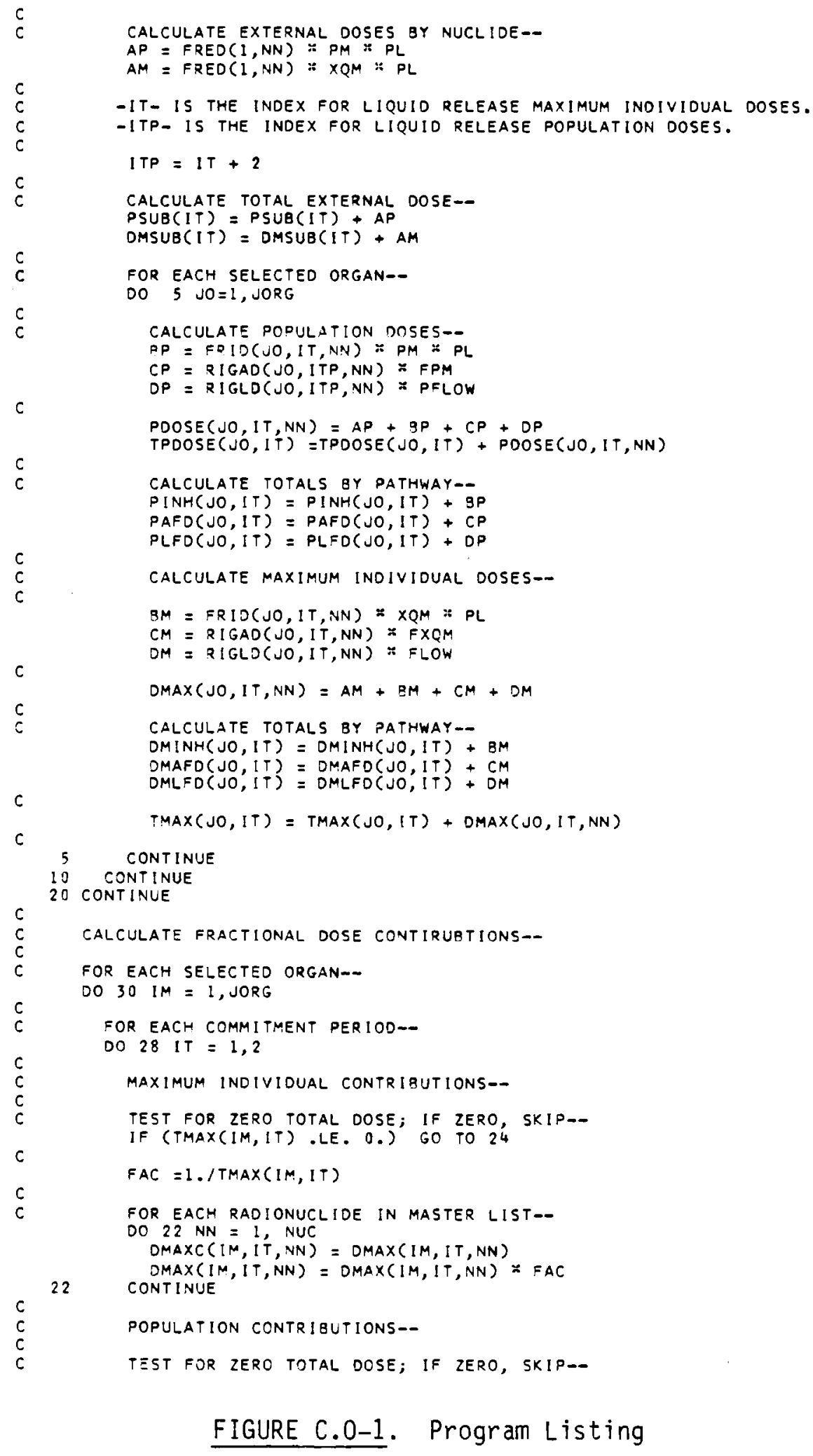
CONTINUE

POPULATION CONTRIBUTIONS--

TEST FOR ZERO TOTAL DOSE; IF ZERO, SKIP--

\section{FIGURE C.0-1. Program Listing}


MODULE DOSECA

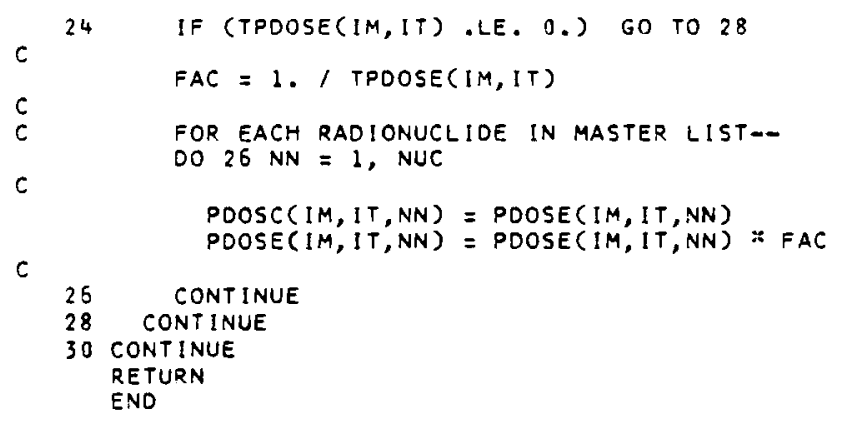

FIGURE C.0-1. Program Listing

C.9 
SURROUTINE EDORG (NORG, IORG, LORG, MORG, JORG, IEND)

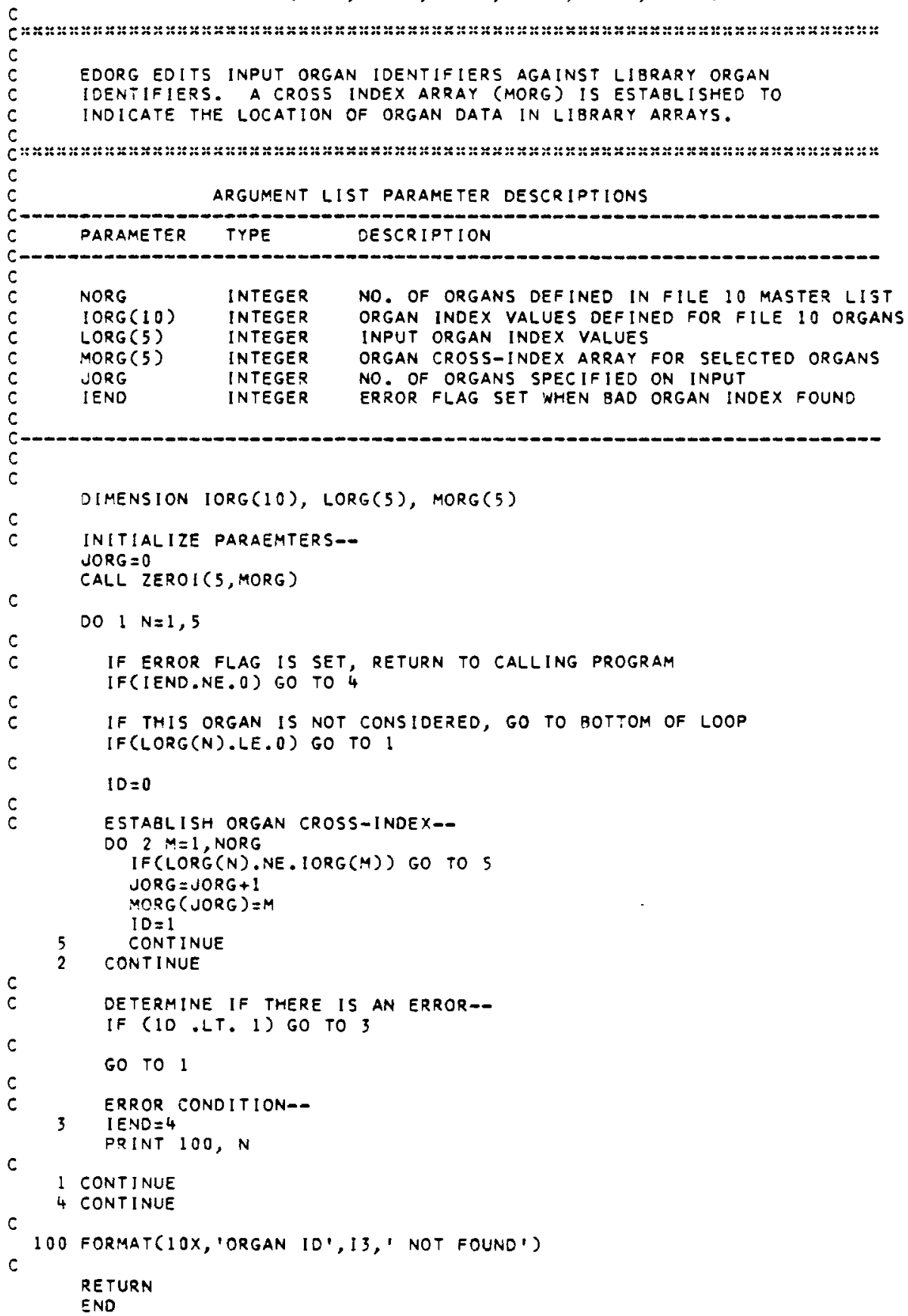

FIGURE C.0-1. Program Listing 
MOOULE FOOLIB

SUGROUTINE FOOLIS (NUC, REC, Q, RIGAD, ?IGLD, LQ, JOQG)

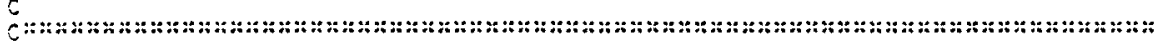

$c$

$c$

C:

c

$\check{c}$

FJOLIB READS DATA FOR FOOO PATHWAY DOSES AND MULTIPLIES BY CI. ARGUMENT LIST PAPAMETER DESCRIPTIONS

PARAMETER TYPE DESCRIPTION

NUC INTEGER NO. OF RADIONUCLIDE IN MASTER LIST

REC(IOO) CHARACTER QADIONUCLIDE NAME FROM THE MASTER LIST

Q(5,100) REAL RELEASE INVENTORY ARRAY

PIGAD REAL TERRESTRIAL PATHWAY DOSE CONVERSION FACTOR

RIGLD REAL WATERBORNE PATHWAY DOSE CONVEOSION FACTOR

LR INTEGER CONTROL INTEGER FOR ACUTE/CHRONIC QELEASE

JORG INTEGER NO. OF ORGANS SPECIFIED ON INPUT

C

DIMENSION PEC $(100), Q(5,100), T I T L E(7), D F(5), R I N(100)$

JIMENSION ?IGAD $(5,4,100)$, QIGLO(5,4,100)

DIMENSION INR(100), DFAA $(5,4,100), \operatorname{DFCA}(5,4,100), \operatorname{DFAL}(5,4,100)$,

6 DFCL $(5,4,120)$

CHARACTER TITLE:10, R[:7, P.IN:7, REC:B

DATA IEPST /1/

CALL ZEROR (2000, QIGAD)

IF (IFRST.GT. I) GO TO 150

IFRST $=$ IFSST + 1

$c$

QEAD DATA FROM FILE 12. FOOO DOSE CONVERSION FACTORS--

READ $(12,100$, END $=99)$ VISO, TITLE

$N I N=0$

$c$

PRINT 200, VISO, TITLE

C LOOP ON DATA SETS--

DO $50 \quad$ ISET $=1,15$

२EAO (12, 100, END=99) NI, TITLE

IF (NI .LE. O) GO TO 1 ifo

NTH $=N i N+1$

IF (ISET .EQ. I) GO TO 10

IF (ISET .LE. 4) GO TO 20

IF (ISET.LE. 8) GO TO 30

IF (ISET.LE. 12) GO TO 40

IS (ISET .LE. IS) GO TO 50

FIPST SET. READ JATA AND ESTARLISH NUCLIDE INDEX ARQAY INR--

10 LOOP ON NUCLIDES--

DO IS $\mathrm{NN}=1$, MISO

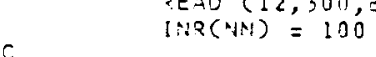

C EI:ID २IN IN MASTEZ ARPAY PEC -

DO 11 IS $=1$, NUC

$150=1 \bar{s}$

11

IF (PEC(IS) .EO. PIM(NN) ) GO TO 12

$c$

CONTI:LUE

PRINT 400, NN, RIN(NN), ISET

$c$ GO TO 15

$12 \ln (4 N)=150$

FIGURE C.0-1. Program Listing 


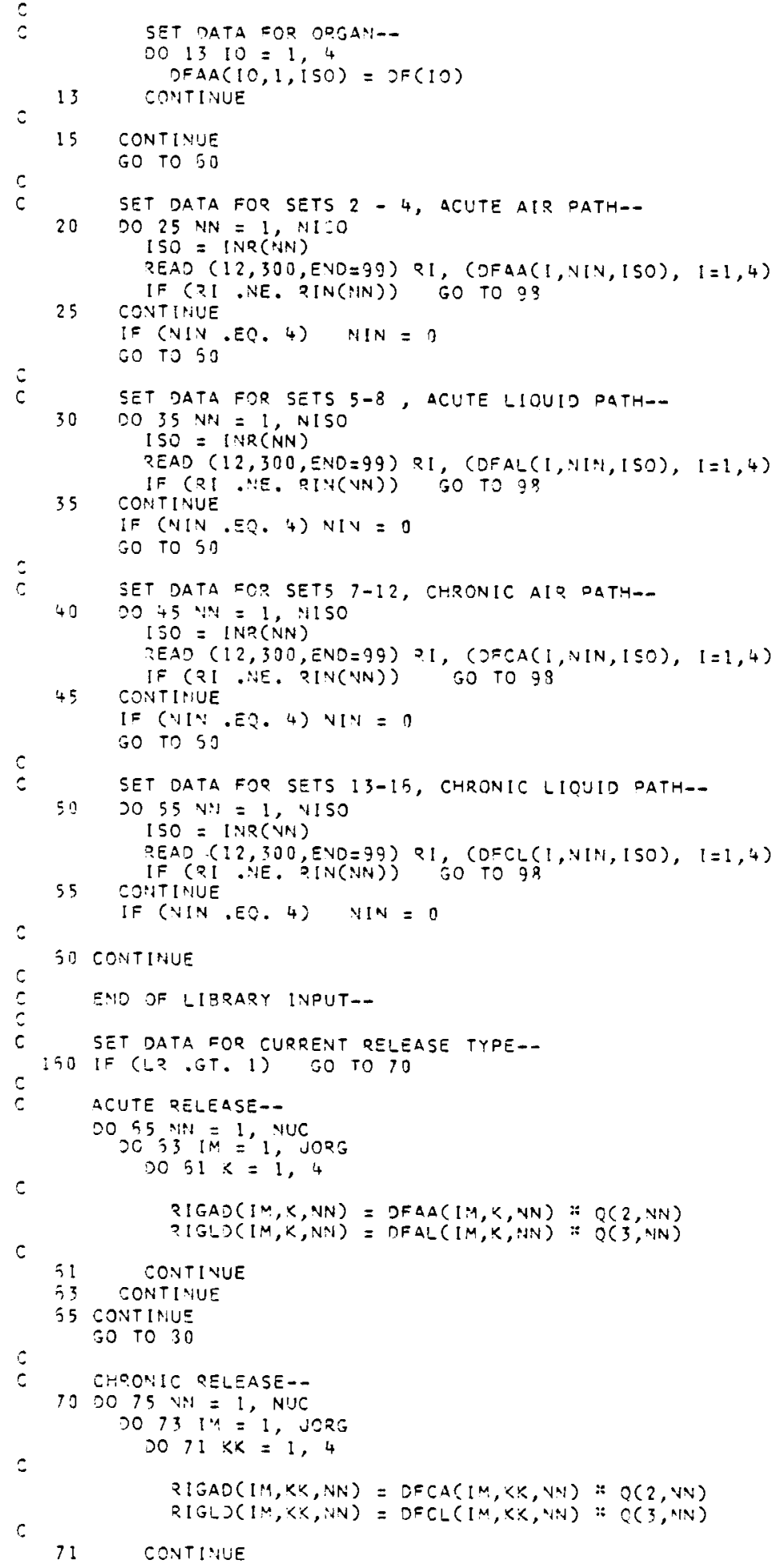

FIGURE C.0-1. Program Listing 
MOOULE FOOLIB

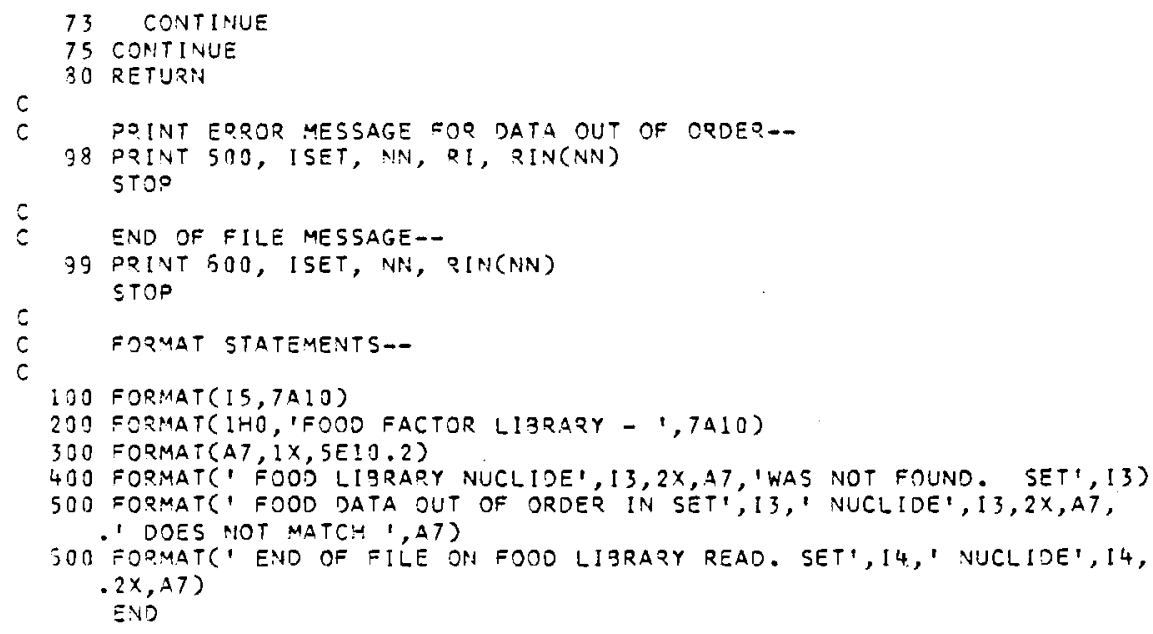

FIGURE C.0-1. Program Listing 
SURROUTINE FRCRPT (NUC, ISO, REC, YA, JORG, MORG, ONAME, TITLE, י: ה: :

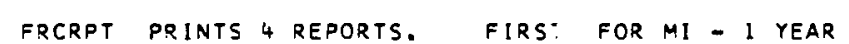

FIGURE C.0-1. Program Listing 


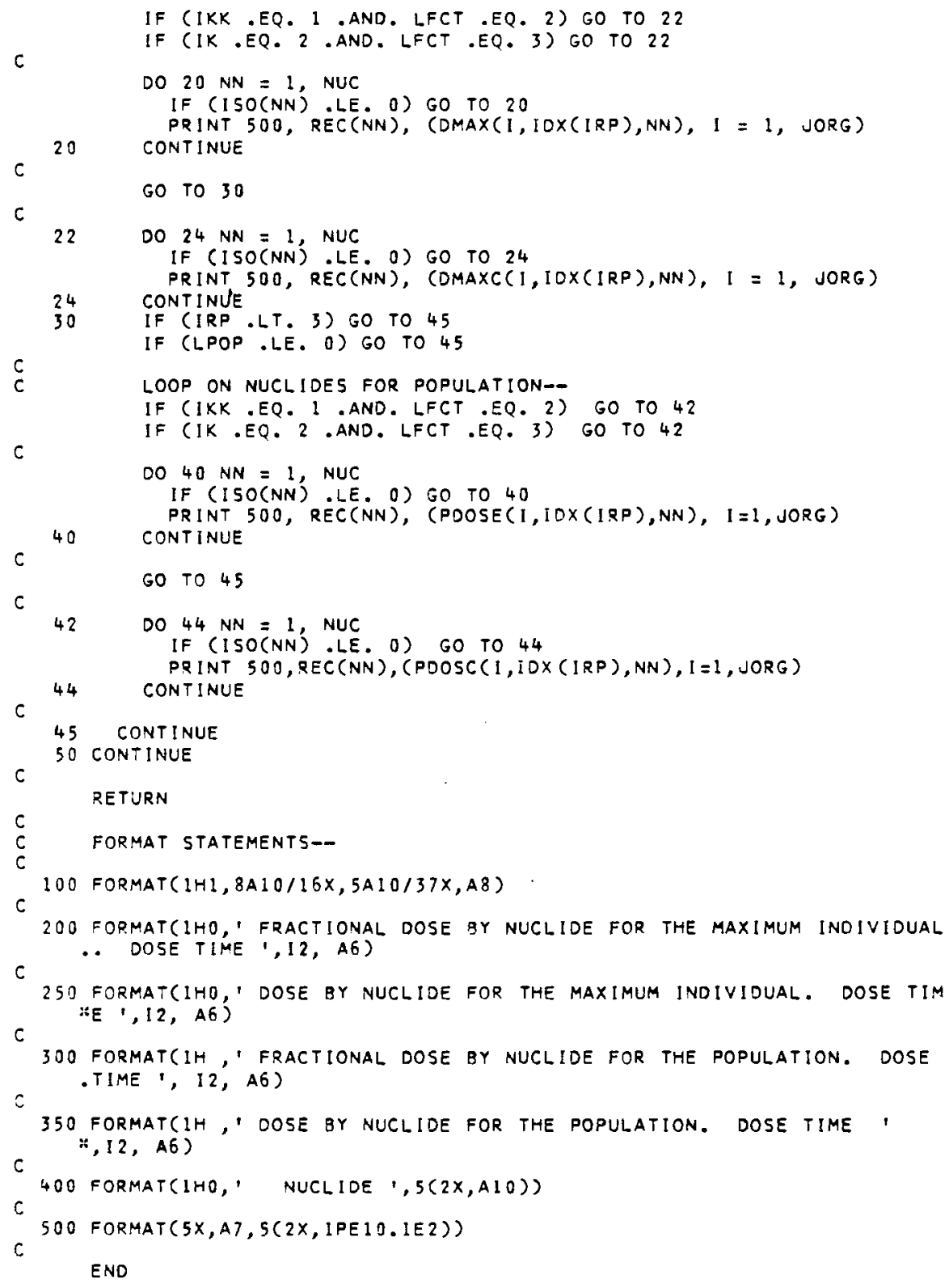

ENO

\section{FIGURE C.0-1. Program Listing}


YODULE GETLIB

SUbroutine GETLIs (NUC, NORG, IORG, REC, EXDF, ODF, ONAME, IEND, $c$ - DAIT)

:

GETLIS PEADS FILE IO DATA LIBQARY

:

ARGUMENT LIST PARAMETER DESCRIPTIONS

PARAMETER TYPE DESCRIPTION

$\frac{c}{6}$

VUC INTEGER

NO. JF RADIONUCLIDES IN MASTER LIST

ORGAY I"DEX VALUES DEFINED FOR FILE 10 ORGANS

REC (10D) CHARACTER QADIONUCLIDE NAME FROM THE MASTER LIST

EXDF( 3,100$)$ DEAL EXTERNAL DOSE FACTORS AROAY

DOF $(5,10,100)$ REAL ORGAN DOSE FACTOR ARRAY

ONAME $(10)$ CHARACTER ORGAN NAMES

IEND INTEGER ERPOR FLAG SET WHEN RAD ORGAN INDEX FOUND

DAIT CHARACTE? DAY-OF-YEAR

INCLUDE ALLDOS.DOSTIM,LIST

DIMENSION REC $(190), \operatorname{ICRG}(10), \operatorname{AL}(100), \operatorname{SXDF}(3,100), \operatorname{ODF}(5,10,100)$, . ONAME (10), OD(5), HEAO( 3$)$

GHA?ACTER HEAD:!0, ONAME:10, REC:?

IEND $=0$

C PEAD FIRST THO CARDS FROM DATA LIBRARY=-

READ $(10,100$, END $=98)$ NUC, NORG, NT, NR, IOPG, HEAD, (ONAME( I), I =1, NORG)

PEAD $(10,100, E N D=98)$ (IDTIME(I), I =1,4)

C IUITIALIZE ARZAYS TO ZERO-D

1 CALL ZEROR (190, AL)

CALL ZEQOO ( 5000 , ODF)

CALI- ZEPOR ( 300, EXDF)

$c$

2EAD DATA FOR EACH NUCLIDE-

DO $101=1$, NUC

READ $(10,200, E N D=95)$ QEC (I), ALC (I), EXDF $(1,1), \operatorname{EXDF}(3,1), \operatorname{EXDF}(2, I), L O$

3 If $(1,0 . L E$, O) GO TO 10

$c$

READ INHALATION DOSE FACTORS--

DO $7: 0=1$, LO

PEAD $(10,300, E N D=95) 40,(O O(J), J=1,5)$

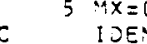

DOENTIEY CURRENT NUCLIDE--

DO 5 NO $=1$, HORG

$[F(I O R G(N O) \cdot E Q \cdot M O) M X=N O$

5 CONTINUE

C IF(MX.LE.OS) GO TO 97

$O D F(1, M X, 1)=O D(1)$

$O D F(2, M X, 1)=O D(2)$

$\operatorname{ODF}(3, M x, 1)=0 D(3)$

$O D F(4, M x, I)=O D(4)$

$O D F(5, M x, 1)=O D(5)$

C

$\operatorname{ODF}(5, M \times, I)=O D(5)$

7 CONTI:HUE

END OF NUCLIDE LOOP--

10 CONTINUE

$c$

PQINT LIBPARY DATA--

CALL LIFRPT(HEAD, NUC, PEC, YOPG, IOPG, AL, EXDF, ODF, ONAME, OAIT)

FIGURE C.0-1. Program Listing

C.16 


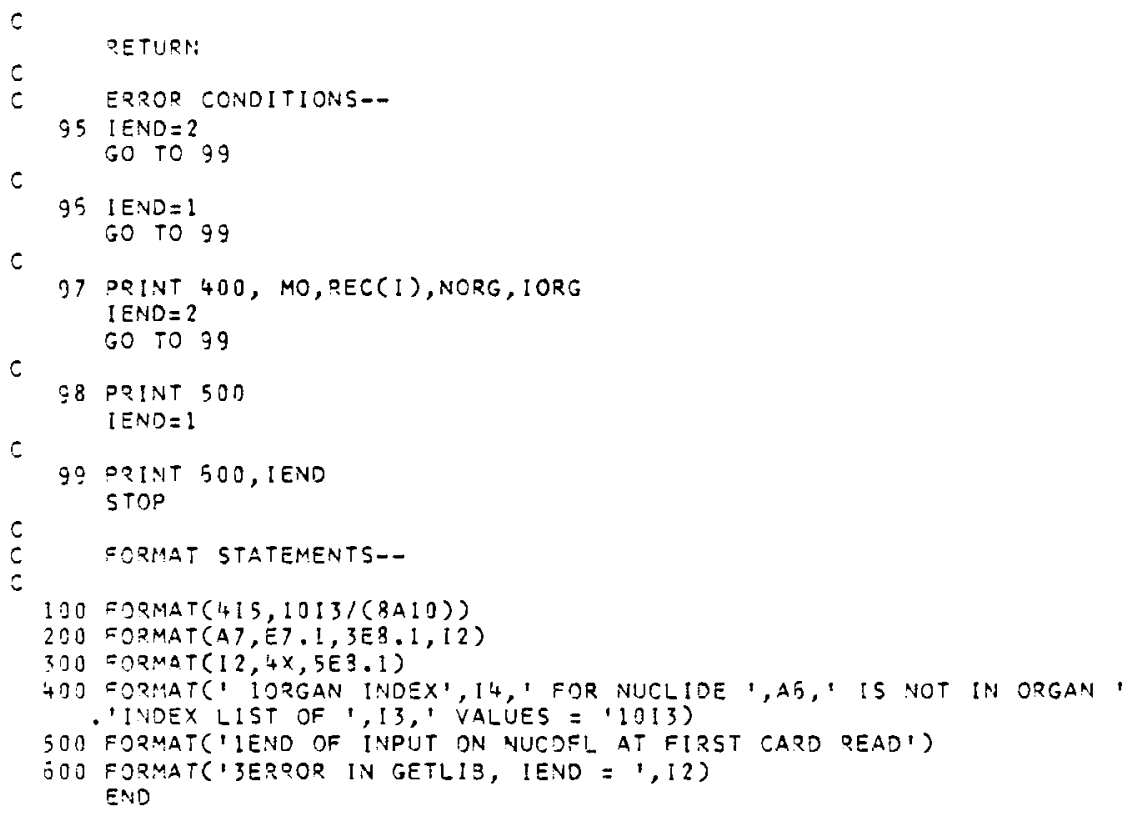

FIGURE C.0-1. Program Listing 


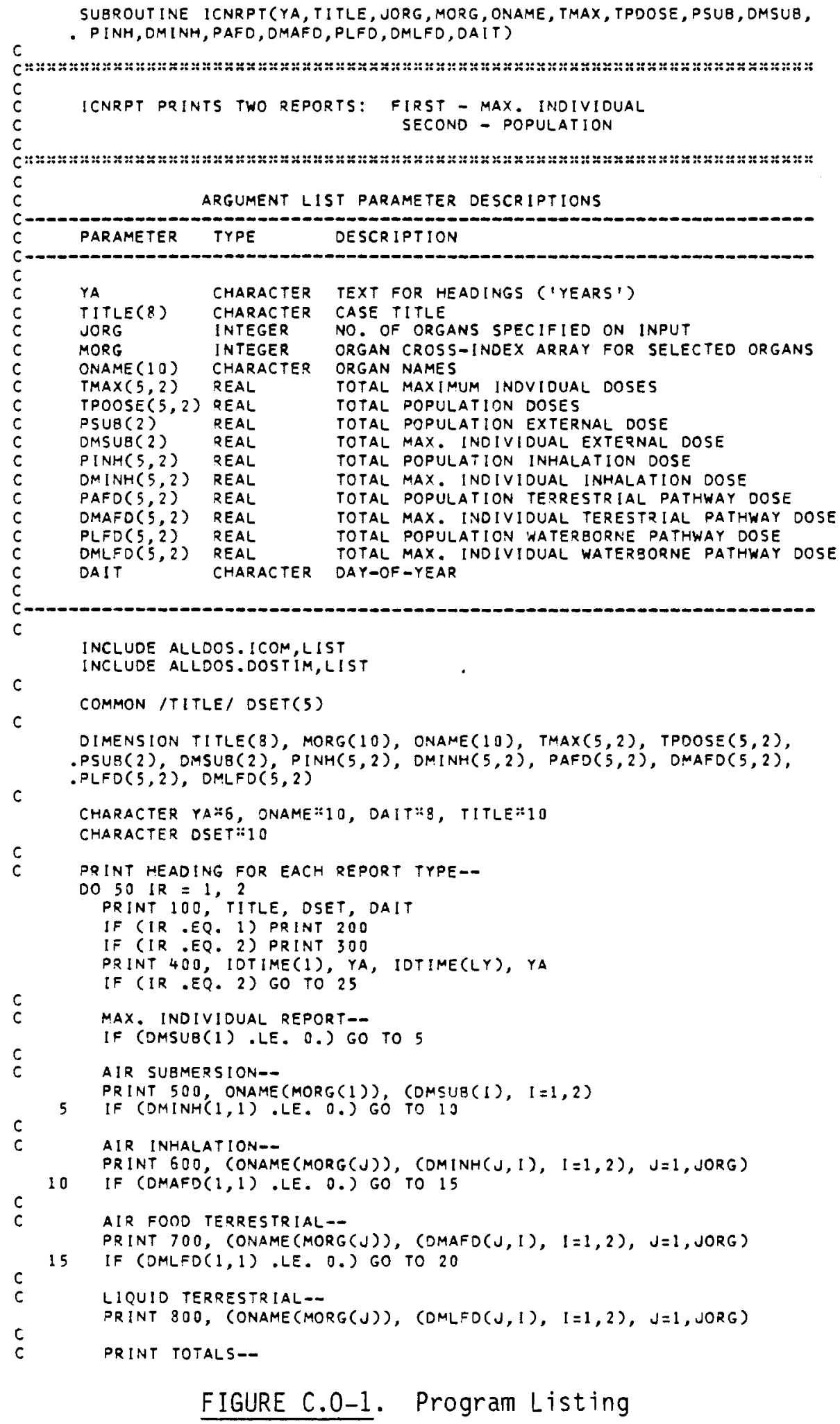




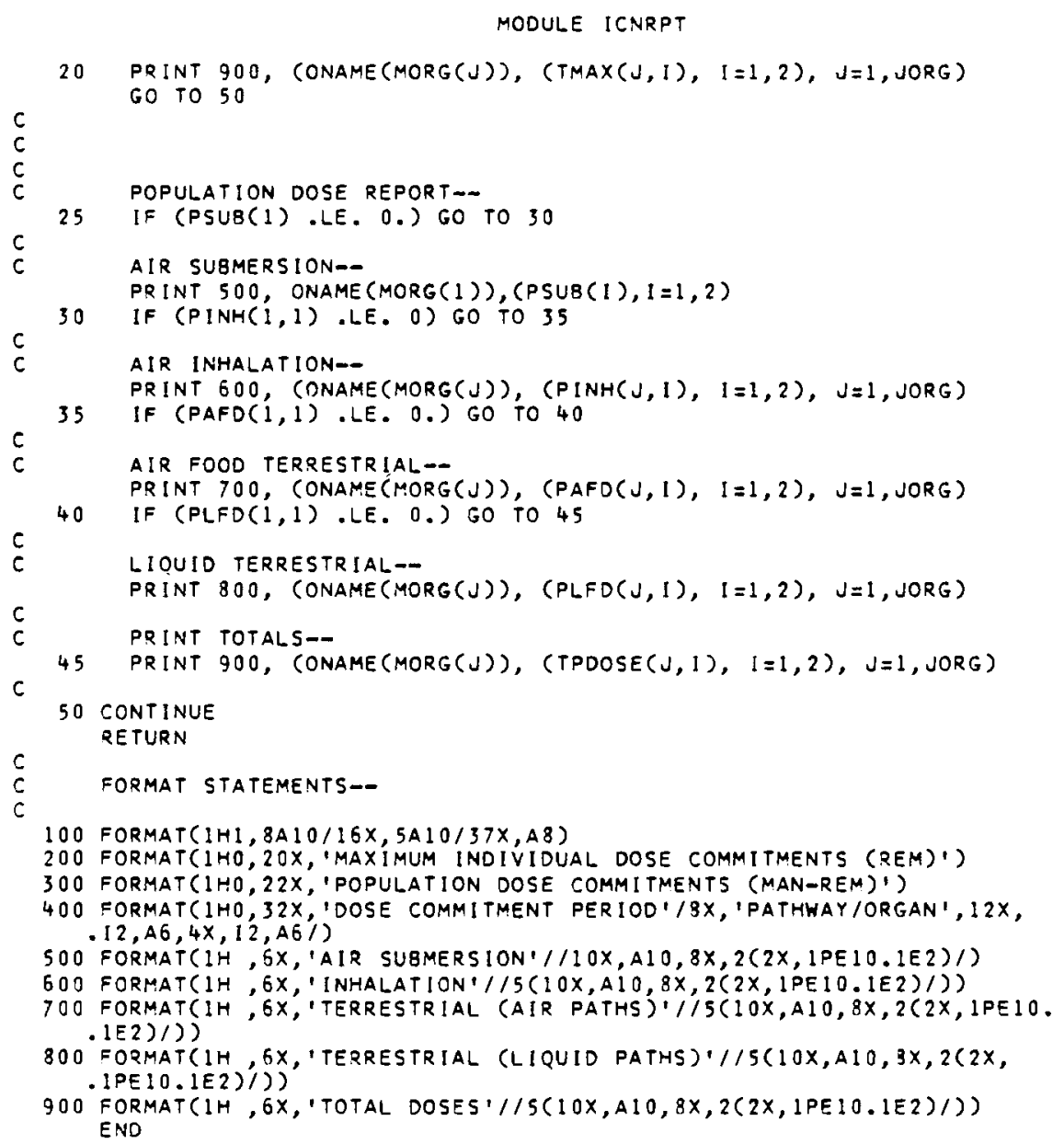

FIGURE C.0-1. Program Listing 


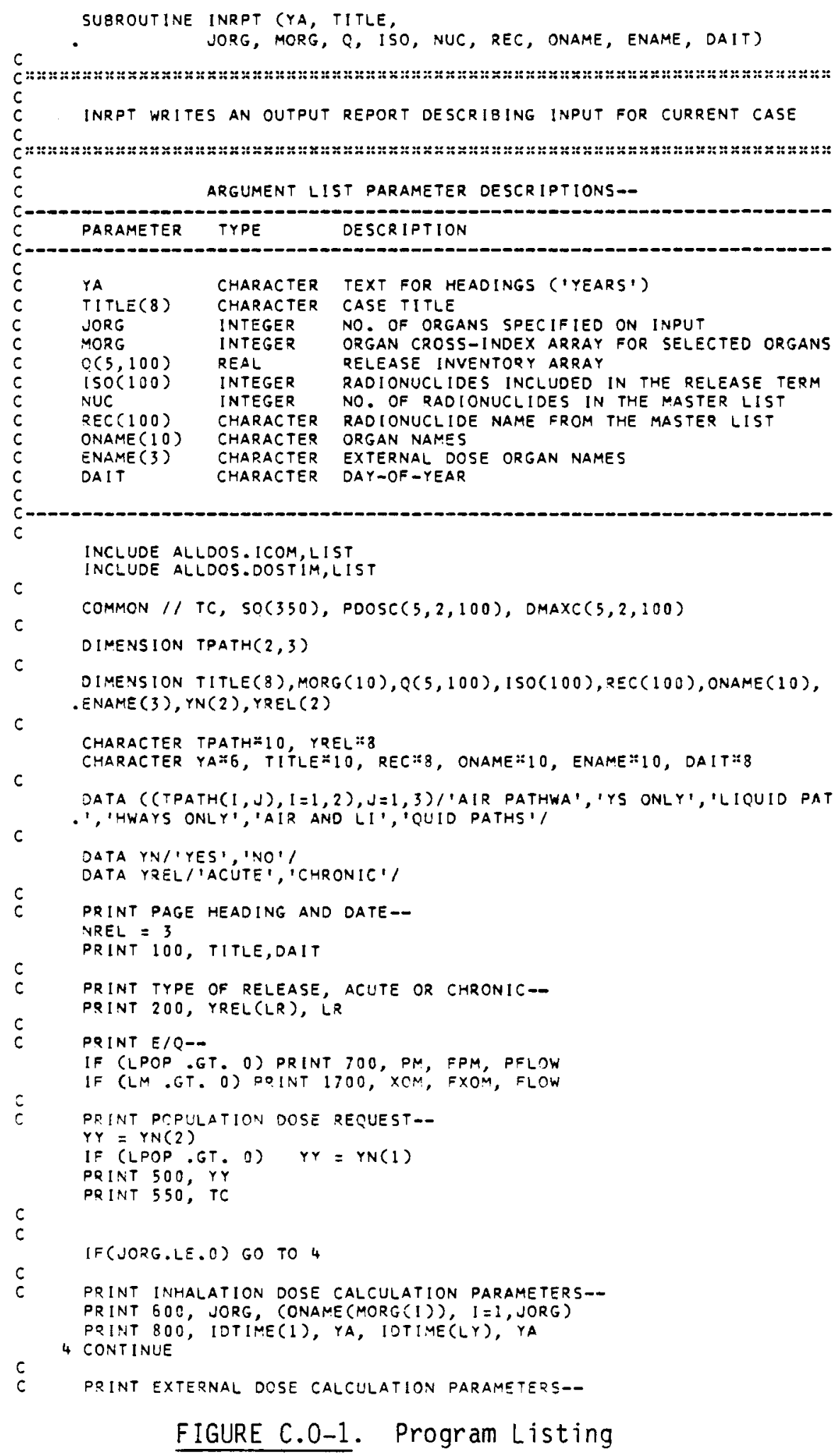

FIGURE C.0-1. Program Listing 


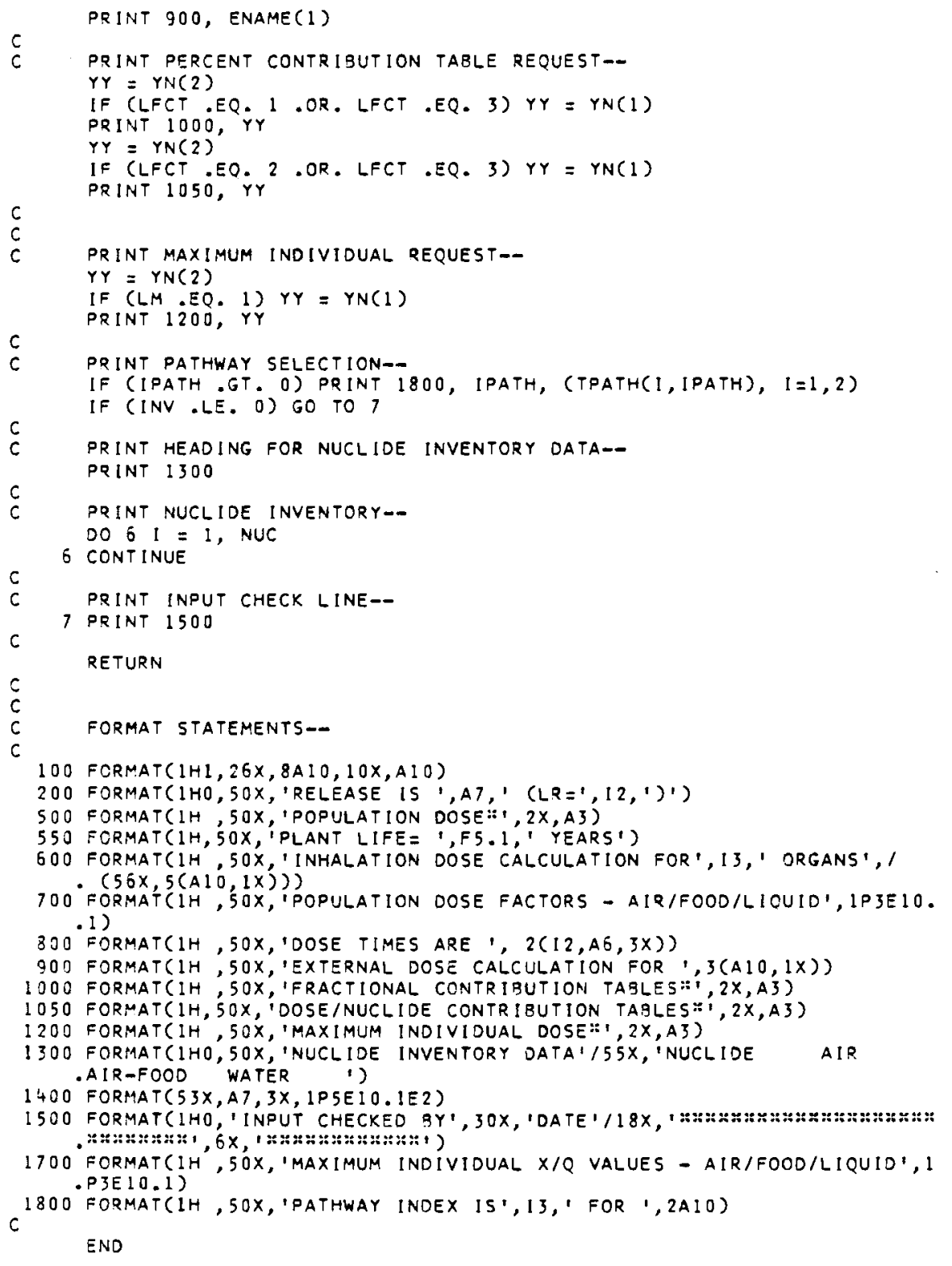

\section{FIGURE C.0-1. Program Listing}


MODULE INVDF

SUgROUTINE INVDFENUC, Q, EXDF, ODF, MORG, JORG, ISO,LQ, LY, FRID, FRED)

C : : :

INVDF CALCULATES INTERMEDIATE FACTOPS FOR EXTERNAL AND INHALATION DOSES

C

ARGUMENT LIST PARAMETER DESCRIPTIONS

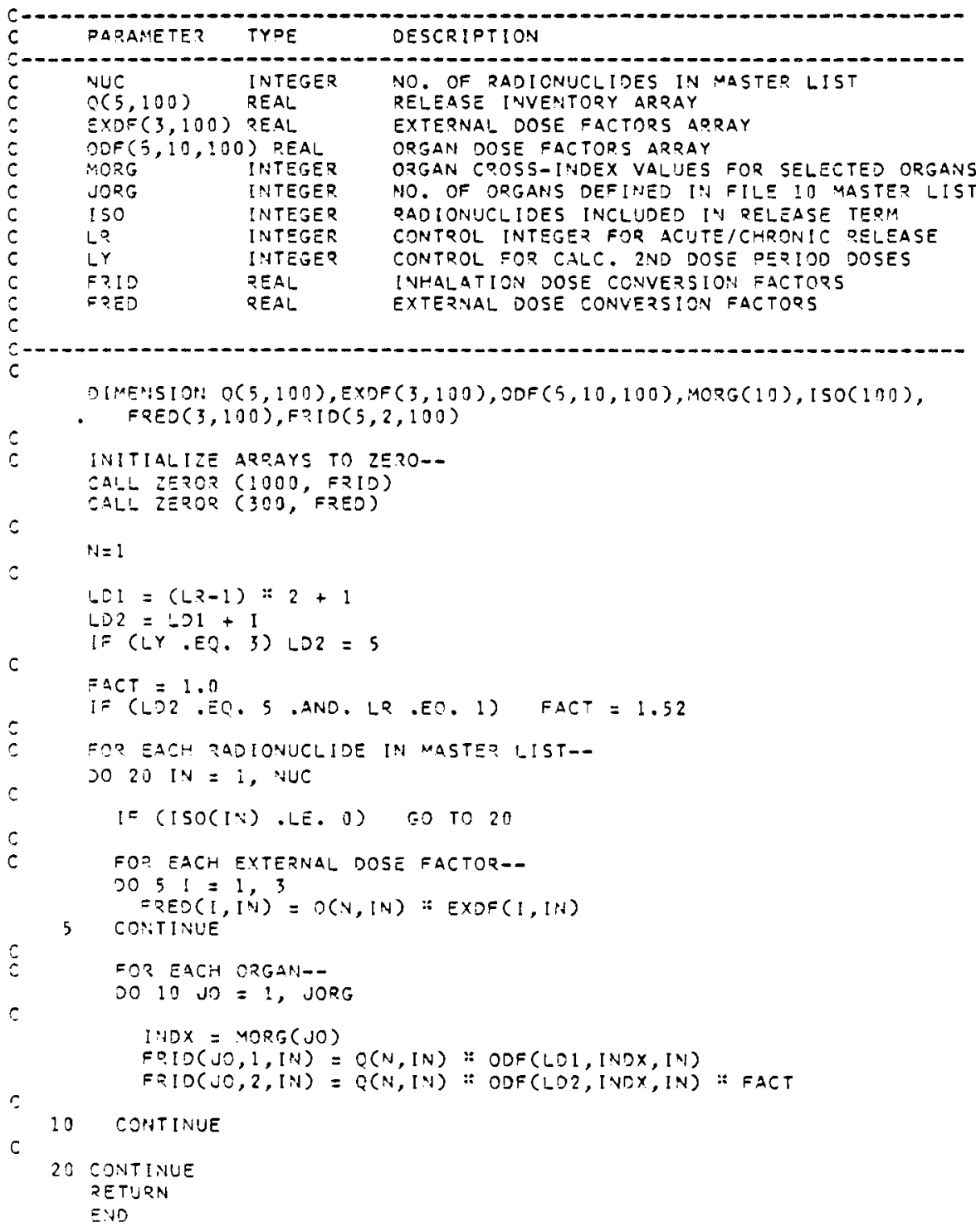

FIGURE C.0-1. Program Listing 
MODULE LIBRPT

SUBROUTINE LIBPRT(HEAD, NUC, YEC, NORG, IORG, AL, EXDF, ODF, OMAME, DAIT)

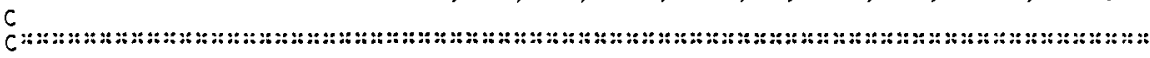

C THIS MODULE PRIMTS A REPORT OF LIBRARY DATA.

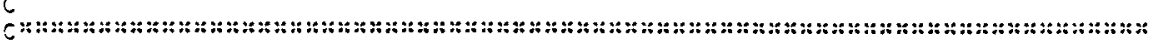

C ARGUMENT LIST PARAMETER OESCRIPTIONS

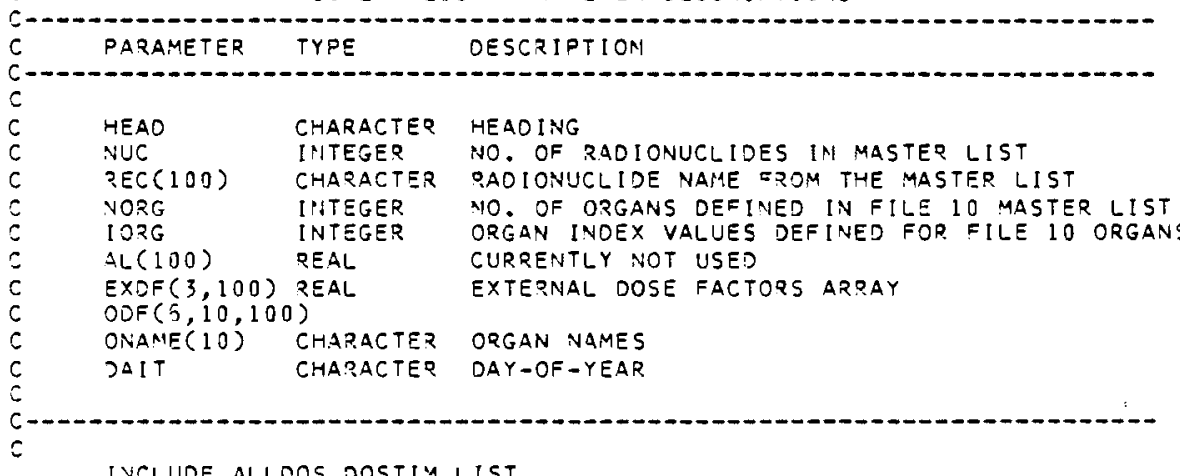

INCLUDE ALLDOS.DOSTIM,LIST

DINENSION HEAD $(3), \operatorname{OORG}(10), \operatorname{AL}(100), \operatorname{EXOF}(3,100), \operatorname{ODF}(5,10,100)$, - ONAME(10), REC(100)

SHARACTES HEAD:10, DAIT:8, REC:3, ONA:AE:10

PRLINT PAGE HEADING--

PQIVT 100

P२LST 200, HEAD, DALT

C SET POINT CONTROL INTEGEQ--

NOMI = NORG -1

$c$

$I N=1$

1 IF (IN .GT. NUC) GO TO 20

IF (IN.GT, 1) PRINT 100

? II:T 300, (IDT!ME(I), I $=1,2)$, (IOTIME(I), I=1,4)

$I C=0$

C POINT DATA FOR A NUCLIOE=-

2 PRINT $400, \operatorname{REC}(I N), \operatorname{EXDF}(1, I N), \operatorname{DNAME}(1)$, . $\operatorname{CODF}(1,1,1 N), 1=1, j)$

iE $\operatorname{CODF}(1,1, i, N)$. LE. O.) GO TO 4

C PRINT REMAINIMG ORGAN OATA-

203 IO $=2, \quad 10 R G$

3 CONTINUE

C

$I C=[C+$ NOM $]$

$+1 C=1 C+2$

$I V=1 N+1$

$c$

IF (IC.GT.43) GO TO 1

IF (IN . LE. NUC) GO TO

C

20 PETURN

0

FOPMAT STATEMENTS-

100 FOZMAT $(1 H 1)$

200 FOPMAT ( $15 X$, 'LIBRAEY DATA $=0 ? ', 2410,5 X$, ALO)

300 FORMATCIHO, GX, 'EXTERNAL DOSE FACTOR', $29 X$ 'INHALATION DOSE FACTORS:

, $148 x$, ACUTE UPTAKE', $15 x$, 'CHPONIC UPTAKE', NUCLIDE', 7X,

- 'TOTAĹ BOJY

. 12,1 YP

ORGA'V', $9 X, I 2,1$ Y

$\therefore$ I 2, I YRS

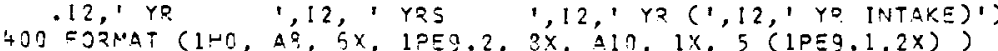

500 FЗRMAT (32x, A13, $1 x, 5(12 E 0.1,2 x) ;$

END

\section{FIGURE C.0-1. Program Listing}




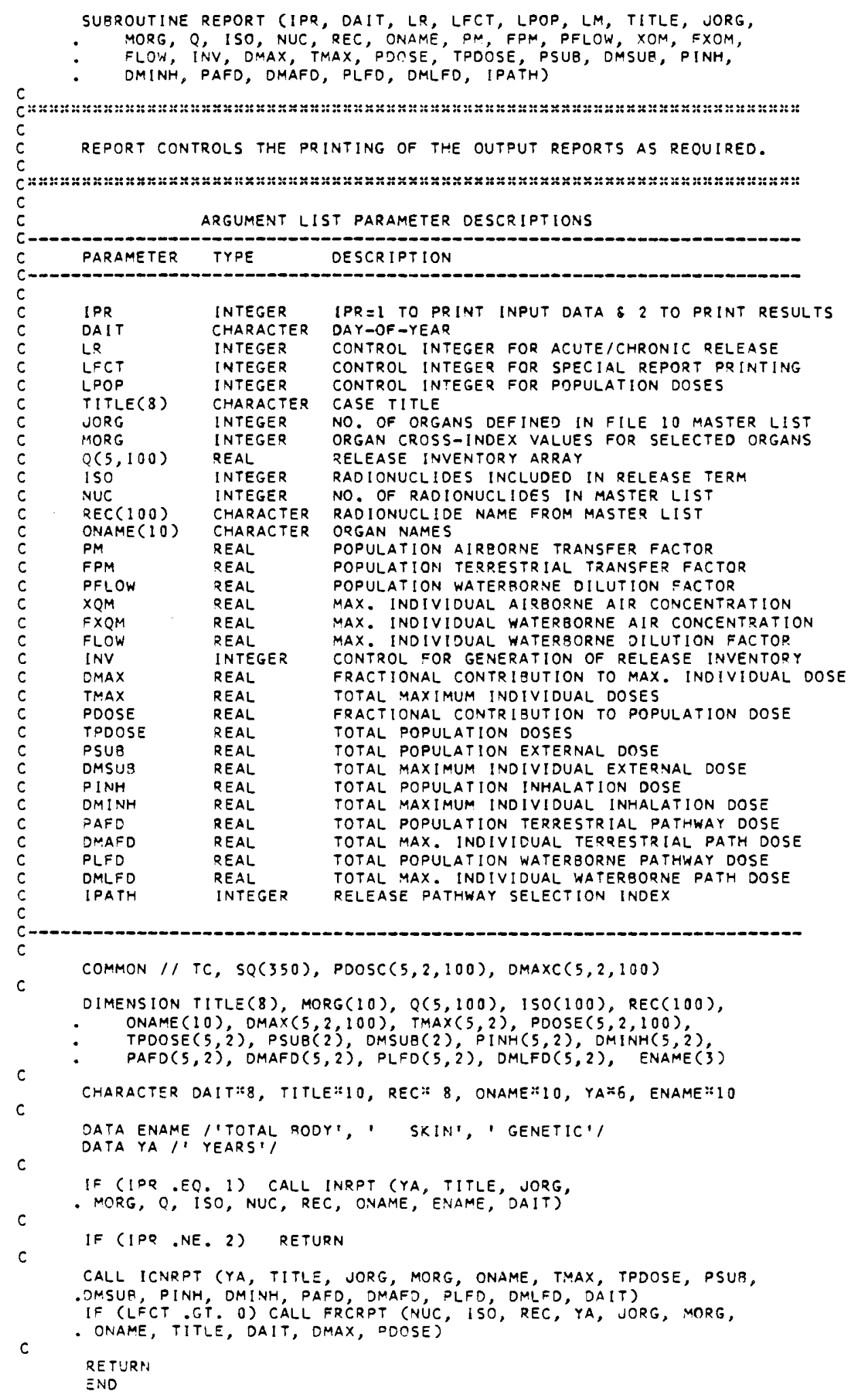

FIGURE C.0-1. Program Listing 
SUBROUTINE SOURCE(NUC, REC, ISO, INV, LADF, LTDF, LFDF, TITLE, Q)

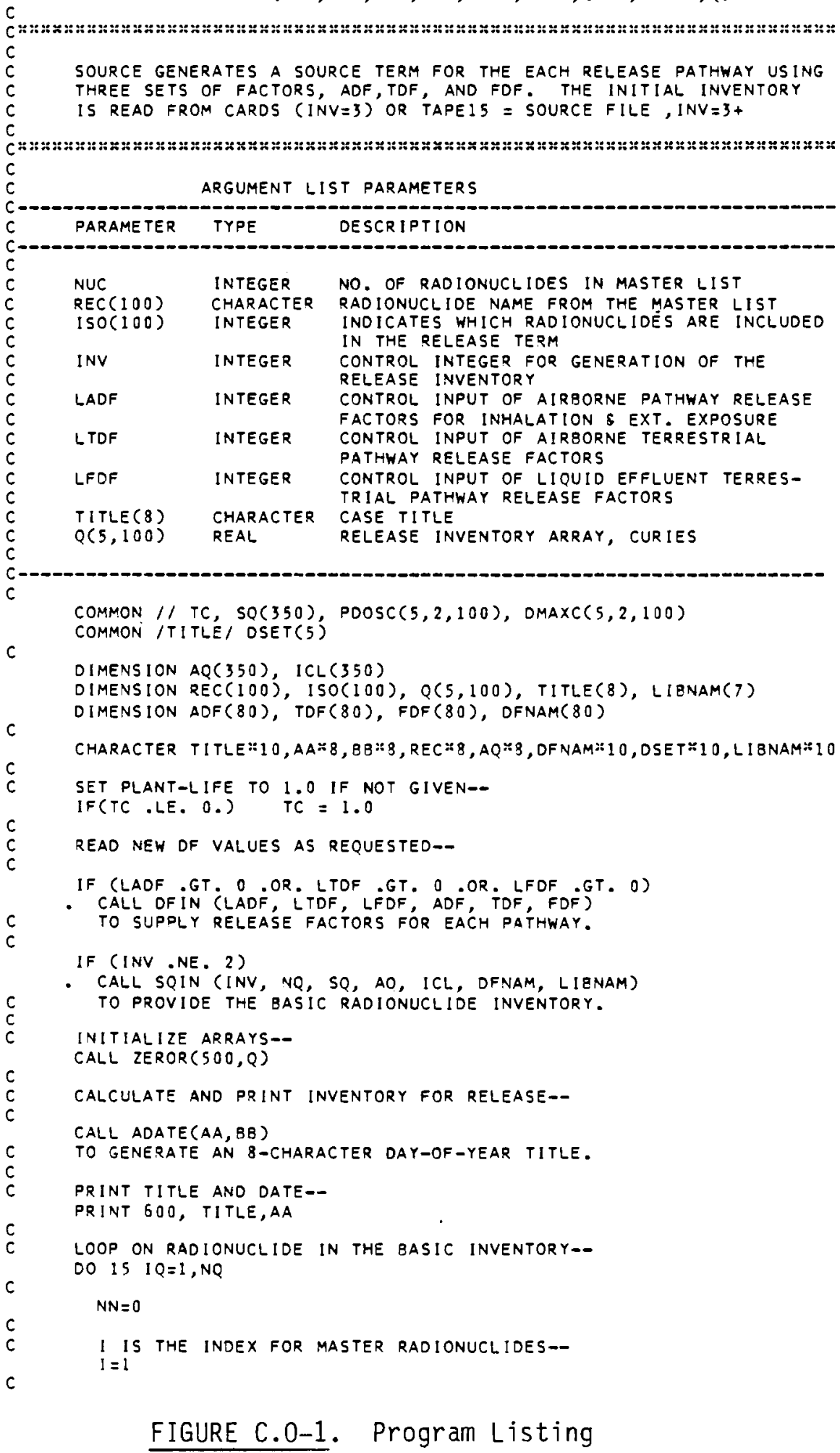




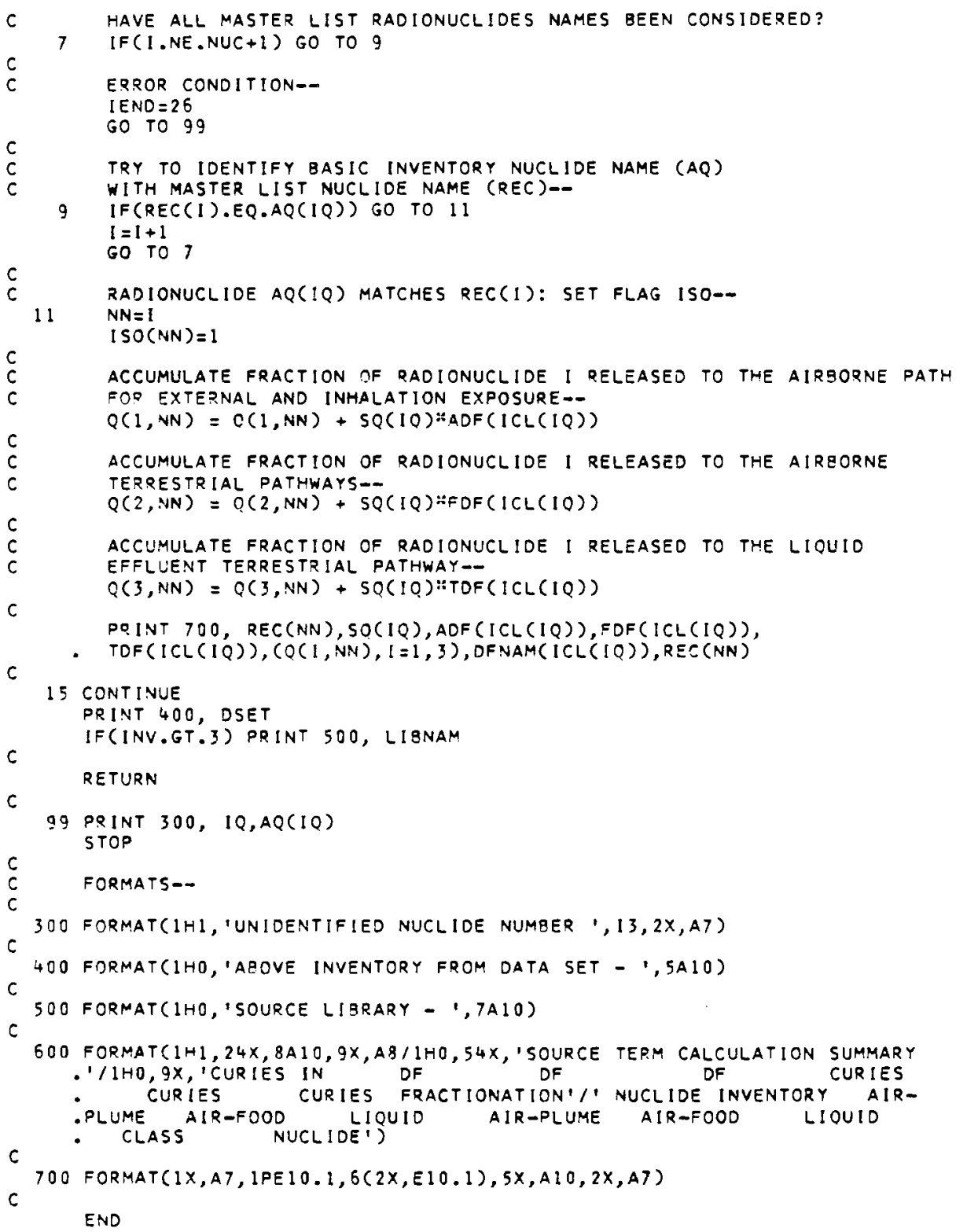

\section{FIGURE C.0-1. Program Listing}


MODULE SQIN

SUBROUTINE SQIN (INV, NQ, SQ, AQ, ICL, DFNAM, LIBNAM)

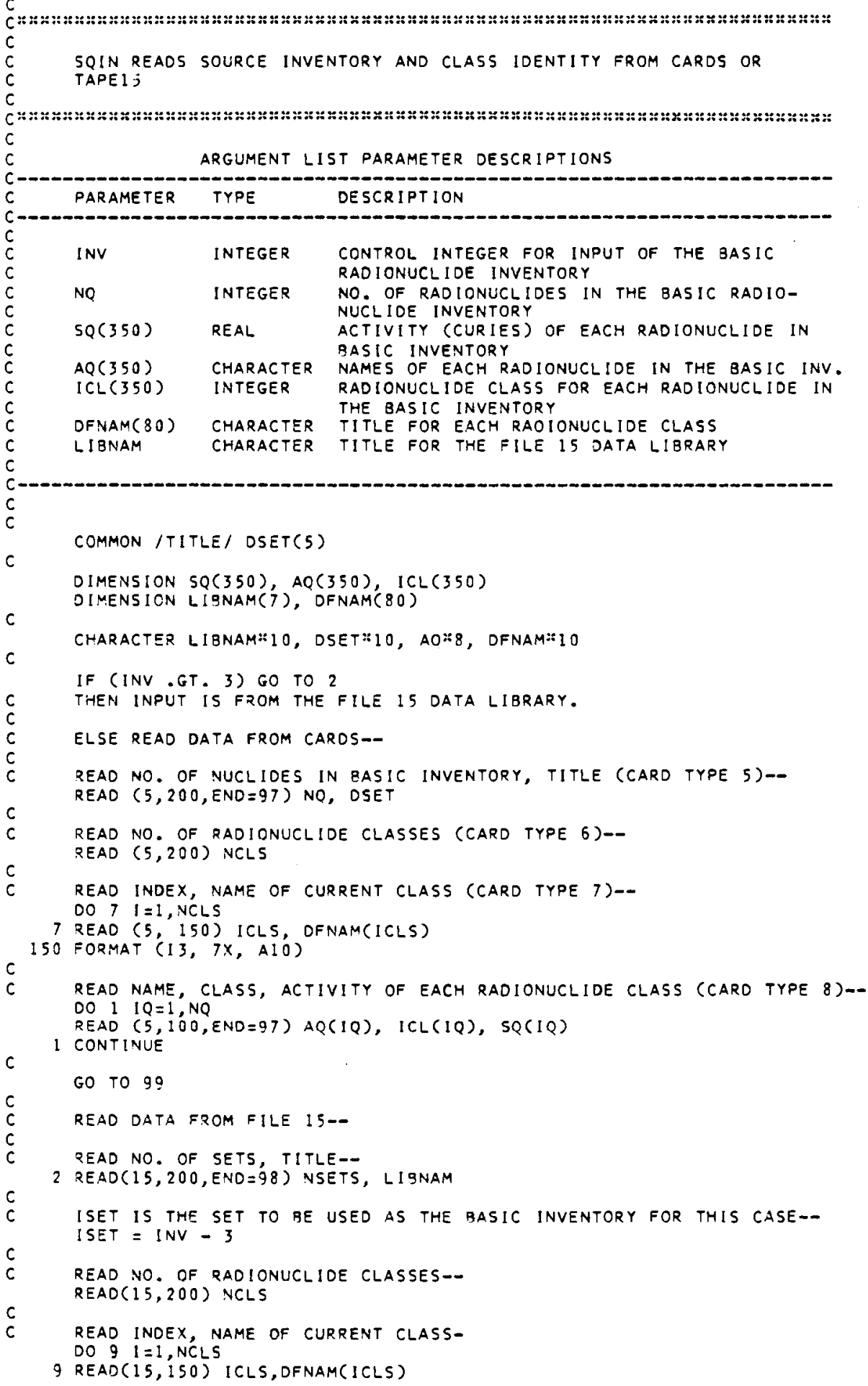

FIGURE C.0-1. Program Listing 
MODULE SOIN

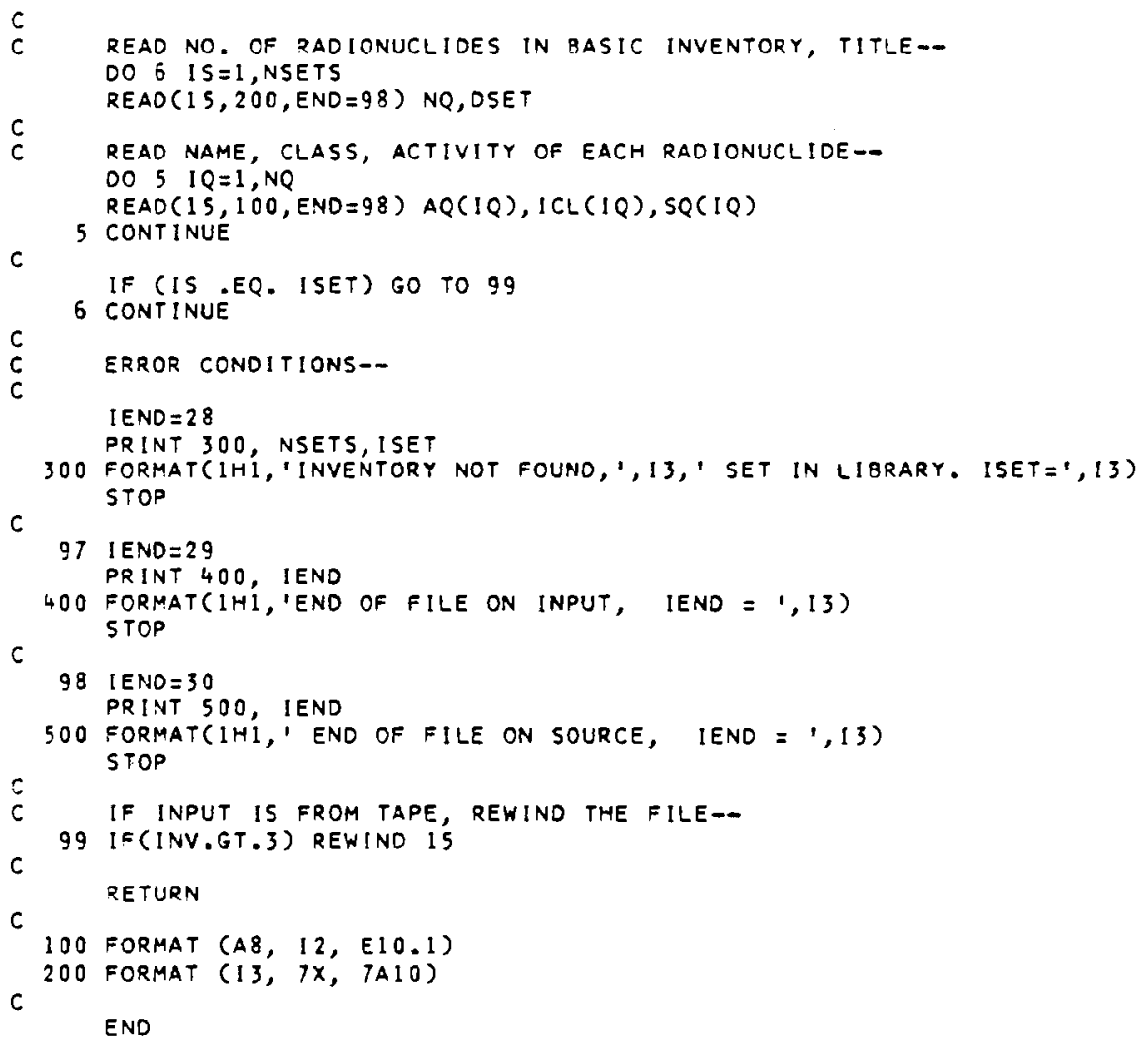

FIGURE C.0-1. Program Listing 


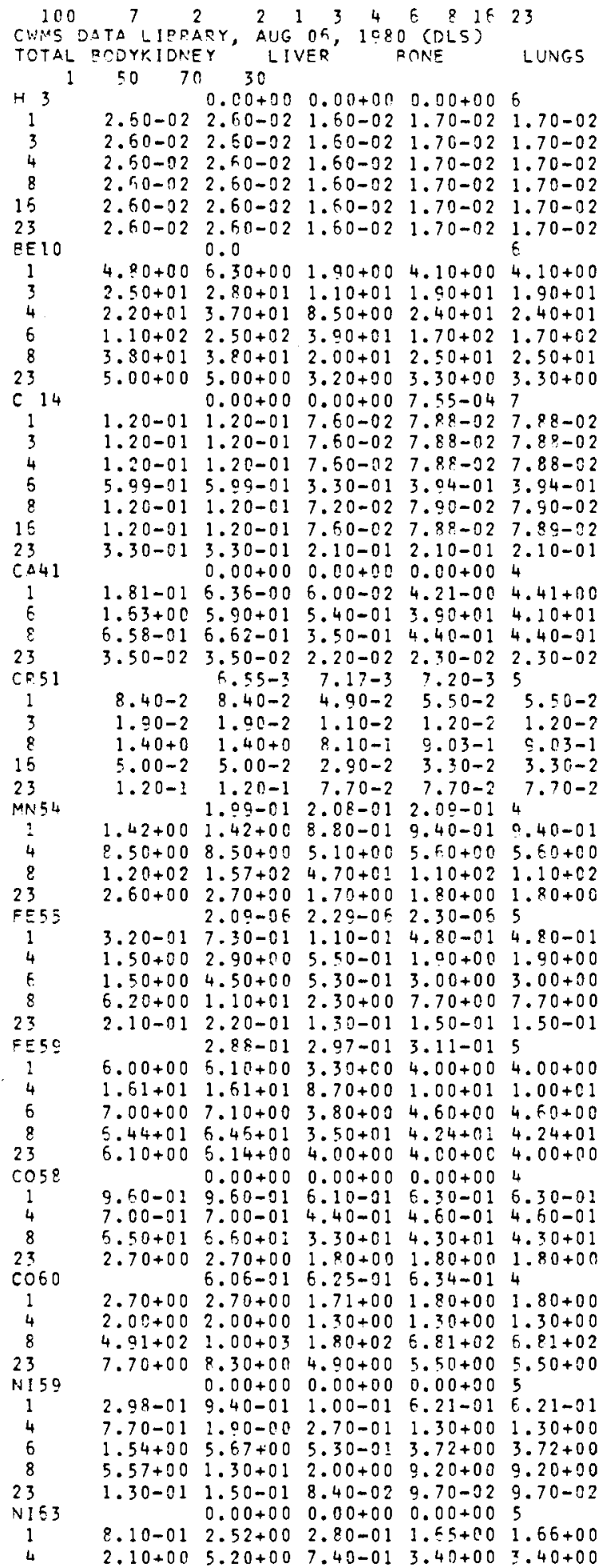

FIGURE C.0-2. File 10 Data Library 


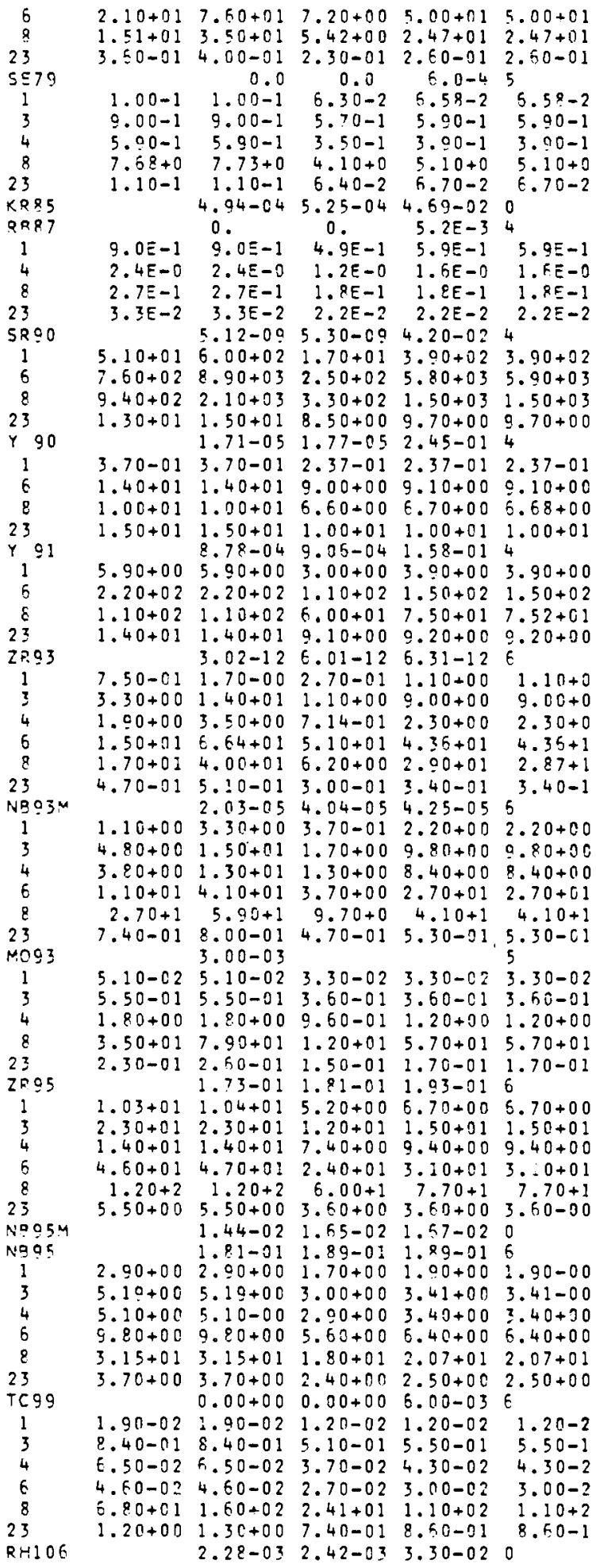

FIGURE C.0-2. File 10 Data Library 


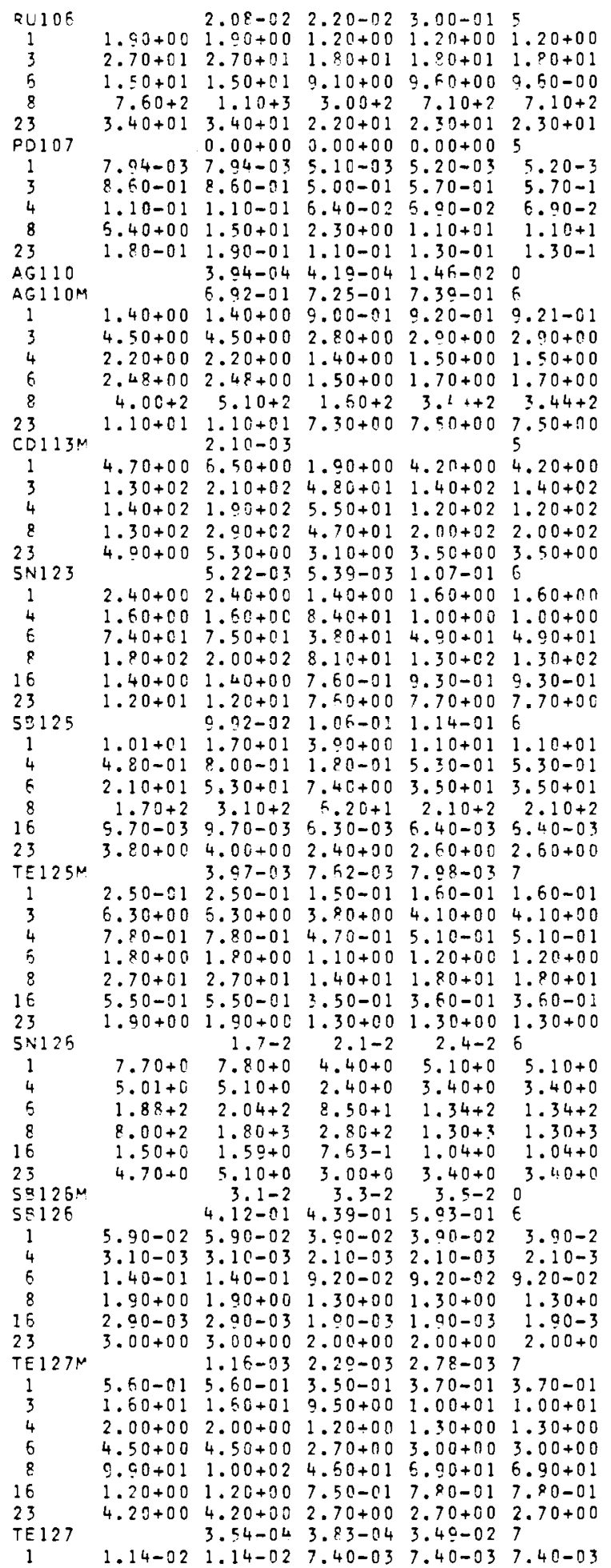

FIGURE C.0-2. File 10 Data Library 


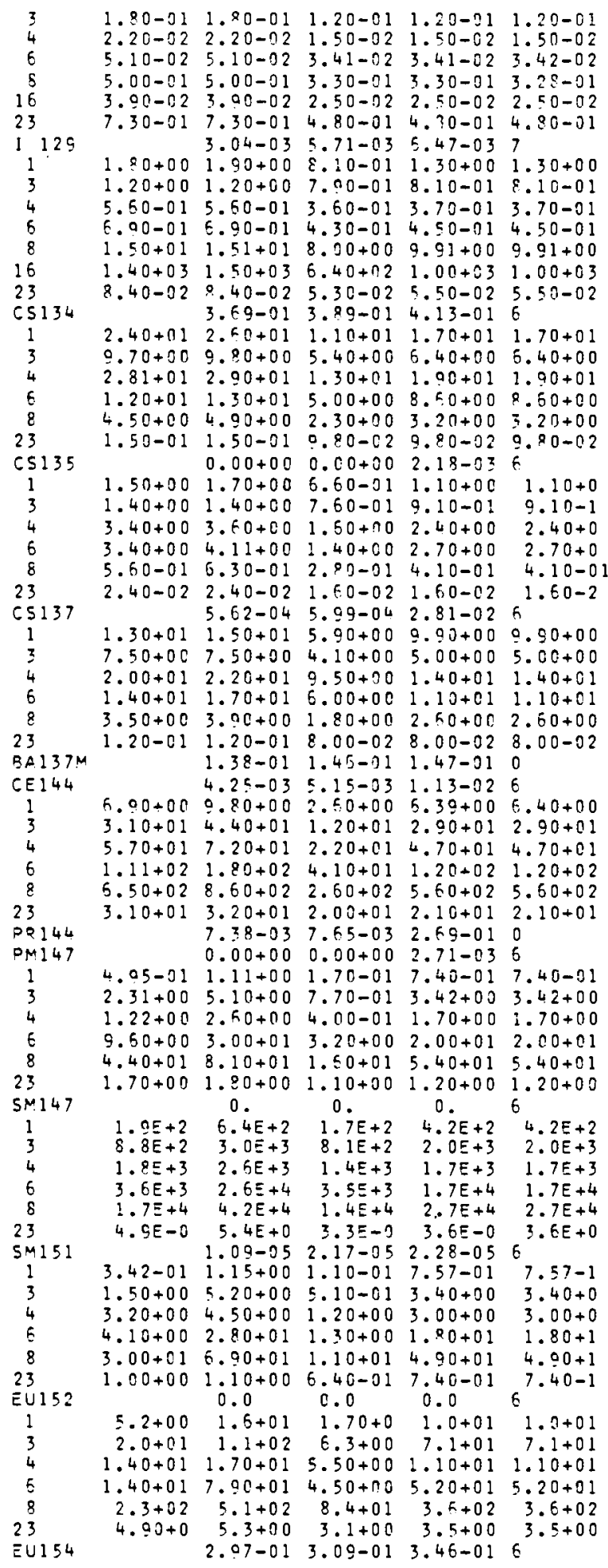

\section{FIGURE C.0-2. File 10 Data Library}




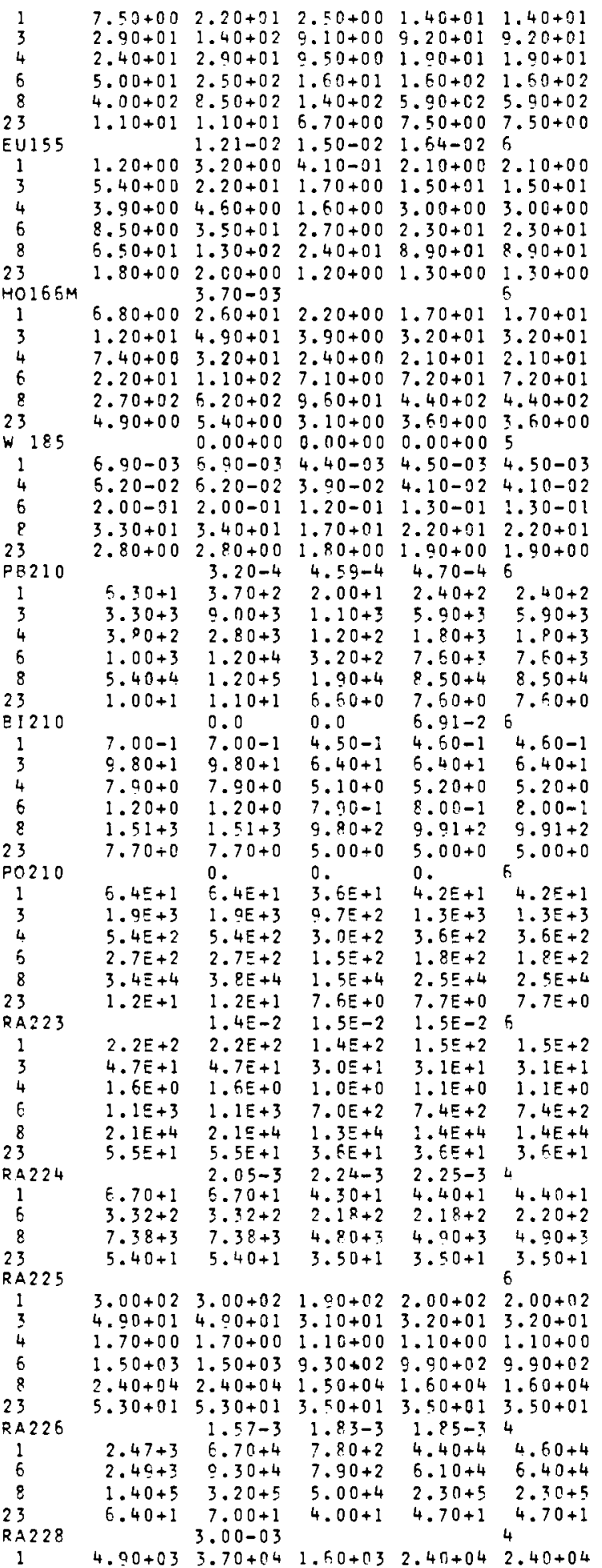

FIGURE C.0-2. File 10 Data Library 


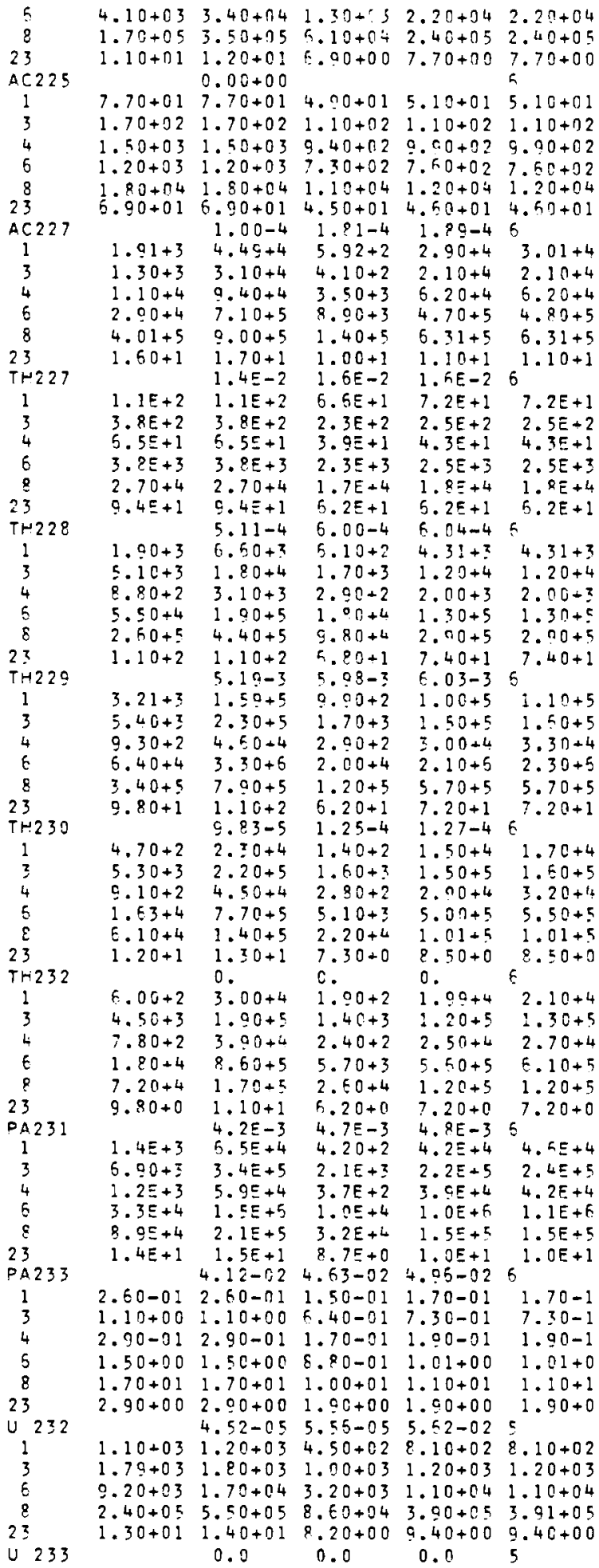

FIGURE C.0-2. File 10 Data Library 


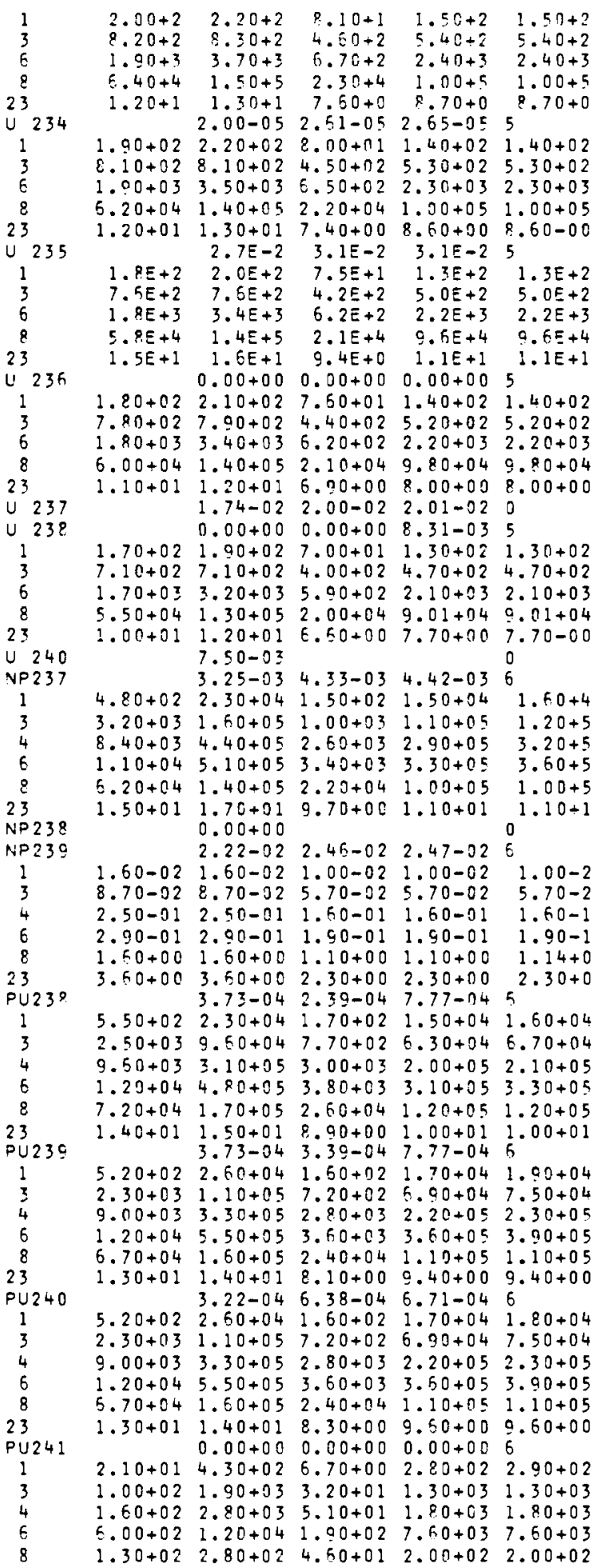

FIGURE C.0-2. File 10 Data Library 


\begin{tabular}{|c|c|c|c|c|c|}
\hline $\begin{array}{l}23 \\
P \cup 242\end{array}$ & $2.70-01$ & $2.00-01$ & $\begin{array}{l}1.70-01 \\
8=0-04\end{array}$ & $\begin{array}{l}2.00-01 \\
8.44-04\end{array}$ & $2.00-01$ \\
\hline 1 & $5.00+02$ & $2.50+04$ & $1.50+02$ & $1.60+04$ & $1.80+04$ \\
\hline 3 & $2.20+0 ?$ & $1.00+05$ & $5.90+02$ & $6.70+04$ & $7.20+04$ \\
\hline 4 & $50+03$ & $3.20+05$ & $0+03$ & $2.10+05$ & $0+05$ \\
\hline 6 & $10+04$ & $5.10+05$ & $3.60+03$ & $3.30+05$ & +05 \\
\hline 8 & $.50+04$ & $1.50+05$ & $2.30+04$ & $1.10+25$ & $1.10+05$ \\
\hline $\begin{array}{l}23 \\
\text { PU243 }\end{array}$ & $0+01$ & $\begin{array}{l}1.40+01 \\
4.20-03\end{array}$ & $2.00+00$ & $9.20+00$ & $\frac{9.20+00}{6}$ \\
\hline 1 & $1.80-03$ & $1.80-03$ & $1.20-03$ & $1.20-03$ & $1.20-03$ \\
\hline 3 & $8.40-03$ & $9.40-03$ & $50-03$ & $5.50-03$ & $0-03$ \\
\hline 4 & $2.20-02$ & $2.20-02$ & $1.40-02$ & $1.40-02$ & $1.40-02$ \\
\hline 5 & $4.50-02$ & $4.50-02$ & $3.00-02$ & $3.0-02$ & $3.0-02$ \\
\hline 8 & $2.20-01$ & $2.20-01$ & $1.40-01$ & $1.50-01$ & $1.50-01$ \\
\hline 23 & $2.20-01$ & $2.20-01$ & $1.50-01$ & $1.50-01$ & $1.50-01$ \\
\hline PU24 4 & & $0.00+00$ & & & 6 \\
\hline 1 & $5.70+02$ & $2.90+04$ & $1.90+02$ & $1.90+04$ & $2.00+04$ \\
\hline 3 & $2.60+03$ & $1.20+05$ & $7.90+02$ & $7.70+04$ & $8.30+04$ \\
\hline 4 & $9.90+03$ & $3.70+05$ & $3.10+03$ & $2.40+05$ & $2.50+05$ \\
\hline 6 & $1.30+04$ & $5.00+05$ & $3.90+03$ & $3.90+05$ & $4.20+05$ \\
\hline 8 & $7.40+04$ & $1.70+05$ & +04 & +05 & $1.20+05$ \\
\hline 23 & $1.90+01$ & $2.10+01$ & $1.20+01$ & $1.40+01$ & $1.40+01$ \\
\hline $\operatorname{AM} 241$ & & $5.03-03$ & 7.2 & $7.42-03$ & 5 \\
\hline 1 & $5.50+02$ & $2.20+04$ & $1.70+02$ & $1.40+04$ & $1.50+04$ \\
\hline 3 & $3.70+03$ & $1.60+05$ & $1.20+03$ & $1.00+05$ & $1.10+05$ \\
\hline 4 & C. $5 \mathrm{C}+03$ & $3.50+05$ & $3.00+03$ & 2. & 2.4 \\
\hline$E$ & 04 & 5.50 & 3.8 & +05 & 3. \\
\hline 8 & $7.20+04$ & $1.70+05$ & $2.50+04$ & $1.20+05$ & $1.20+0.5$ \\
\hline $\begin{array}{l}23 \\
\operatorname{Ar} 242 M\end{array}$ & $1.40+01$ & $\begin{array}{l}1.50 \div 01 \\
8.34-04\end{array}$ & $\begin{array}{r}9.00+00 \\
61-03\end{array}$ & $1.00+0 ?$ & $1.00+01$ \\
\hline 1 & $5.00+02$ & $2.21+04$ & $1.80+02$ & $1.40+04$ & $\therefore .50+04$ \\
\hline 3 & $4.00+0 ?$ & $1.60+05$ & $1.20+03$ & $1.00 \rightarrow C 5$ & $1.10+0.5$ \\
\hline 4 & $9.60+03$ & $3.30+95$ & $3.00+03$ & $2.10+05$ & $2.20+05$ \\
\hline 6 & $1.30+04$ & $5.60+0.5$ & $4.10+93$ & $3.60+05$ & $3.00+0=$ \\
\hline 8 & $5.10+04$ & $1.20+05$ & $1.80+04$ & $8.30+04$ & $2.30+04$ \\
\hline 23 & $1 . \varepsilon 0+01$ & $00+01$ & $1.10+01$ & $1.30+01$ & $1.30+01$ \\
\hline$A N 242$ & & $5.74-04$ & $1.34-03$ & $2.30-12$ & e \\
\hline 1 & $1.10+00$ & $\therefore 10+00$ & $7.40-01$ & $7.40-01$ & $7.40-01$ \\
\hline 3 & & 7.50 & $4.90+00$ & $4.90+00$ & $4.50+00$ \\
\hline 4 & $1.00+01$ & $1.90+01$ & $1.20+01$ & $1.20+01$ & $1.20+01$ \\
\hline 5 & $0+01$ & $2.50+01$ & $i .70$ & $1.70+01$ & $1.70+01$ \\
\hline 8 & $0+02$ & $2.40+02$ & $1.50+02$ & +02 & $1.60+02$ \\
\hline 23 & $1.60+00$ & $1.60+00$ & $1.00+00$ & $1.00+00$ & $1.00+00$ \\
\hline$A M 243$ & & $3.24-04$ & $4.5 \subseteq-04$ & -04 & $\dot{E}$ \\
\hline 1 & $5.20+02$ & $2.20+04$ & 1. $\mathrm{RO}+02$ & $1.40+04$ & $1.50+04$ \\
\hline 3 & $3.60+03$ & $1.60+05$ & $1.10+03$ & $1.00+05$ & $1.10+05$ \\
\hline 4 & $0+03$ & $3.40+05$ & $2.80+03$ & $2.20+05$ & $2.40+05$ \\
\hline 6 & $0+04$ & $5.50+05$ & $3.60+03$ & $60+05$ & $3.90+05$ \\
\hline 8 & $6.90+04$ & $1.60+05$ & $2.40+04$ & $1.10+05$ & $1.10+05$ \\
\hline 23 & $1.70+01$ & $1.80+01$ & $1.10+01$ & $1.20+01$ & $1.22+01$ \\
\hline$C M_{2}$ & & 05 & 05 & 05 & \\
\hline 1 & $3.70+02$ & $4.90+02$ & $1.50+02$ & $0+02$ & $3.20+02$ \\
\hline 3 & 03 & $2.20+03$ & 5.40 & 1. & +03 \\
\hline 4 & 5.40 & $30+03$ & 2.5 & +03 & +03 \\
\hline 5 & $8.40+03$ & $1.10+04$ & $3.30+33$ & $7.30+03$ & $7.30+03$ \\
\hline 8 & $0+04$ & $5.00+04$ & $1.90+04$ & $3.30+04$ & $3.30+04$ \\
\hline 23 & +01 & $50+01$ & $9.50+00$ & $?+00$ & +00 \\
\hline $\operatorname{Cos} 2$ & & $1.70-02$ & & & \\
\hline 1 & 2 & $1 . \leq 0+04$ & 1. & 1.0 & 1.0 \\
\hline 3 & & & & & .04 \\
\hline 4 & $1.00+04$ & $2.40+05$ & $3.10+03$ & $1.60+05$ & $1.60+05$ \\
\hline$\underline{5}$ & & $3.70+05$ & $4.00+103$ & $2.40+05$ & +0 \\
\hline 8 & $0+04$ & $1.70+05$ & $2.70+04$ & $1.20+05$ & $1.20+0.5$ \\
\hline 23 & $1.50+01$ & $1.50+01$ & $9.50+00$ & $1.10+01$ & $1.10+01$ \\
\hline$C M 2$ & & & & & \\
\hline 1 & $5.50+02$ & $1.20+04$ & $1.70+02$ & $7.60+0 ?$ & $7.80+03$ \\
\hline 3 & $0+03$ & $30+04$ & $7.70+02$ & $3.50+04$ & $3.50+04$ \\
\hline 4 & $60+03$ & $60+05$ & $2.70+03$ & $10+05$ & $10+05$ \\
\hline 6 & $1.20+04$ & $80+05$ & $3.90+03$ & $1.80+05$ & $90+05$ \\
\hline 8 & $7.50+04$ & $1.70+05$ & $2.70+04$ & $.20+05$ & $20+05$ \\
\hline 23 & $1.50+0 ?$ & $60+01$ & $9.20+00$ & & $10+0$ \\
\hline & & 3 & -03 & $-0 ?$ & \\
\hline 1 & $5.40+02$ & $.20+04$ & $1.70+92$ & $1.50+04$ & $60+04$ \\
\hline
\end{tabular}

\section{FIGURE C.0-2. File 10 Data Library}




$$
\begin{aligned}
& 2.50+03 \quad 1.10+057.50+02 \quad 5.00+047.40+04 \\
& \text { c. } 50+03 \quad 3.50+052.00+032.30+052.50+05
\end{aligned}
$$

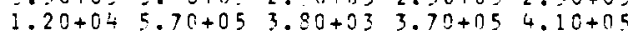

$$
\begin{aligned}
& i .00+041.60+05 \quad 2.50+04 \quad 1.20+051.20+05 \\
& 1.40+011.50+018.50+00 \quad 9.30+00 \quad 0.00-00 \\
& 0.00+00
\end{aligned}
$$

FIGURE C.0-2. File 10 Data Library 


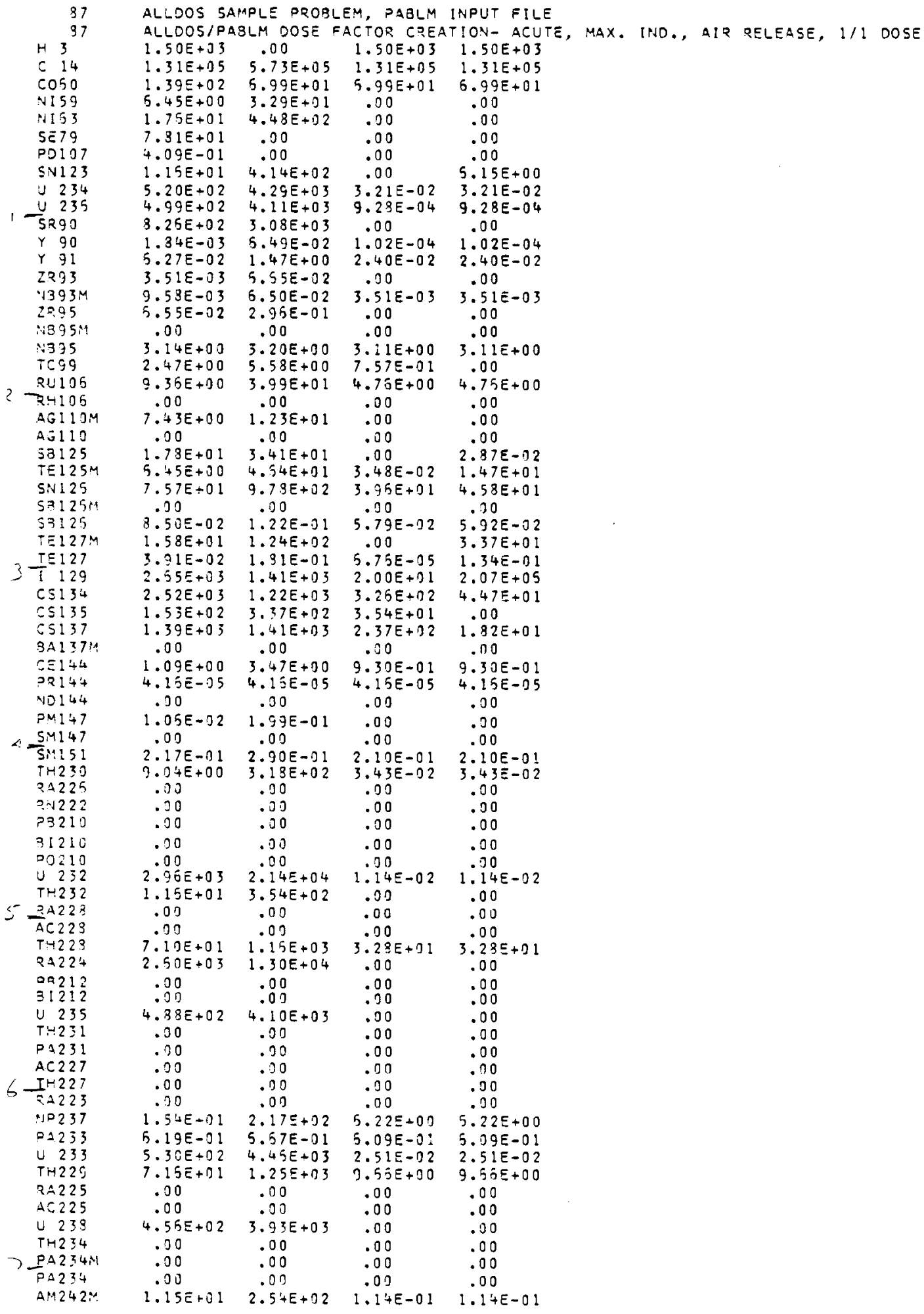

FIGURE C.0-3. File 12 Data Library 


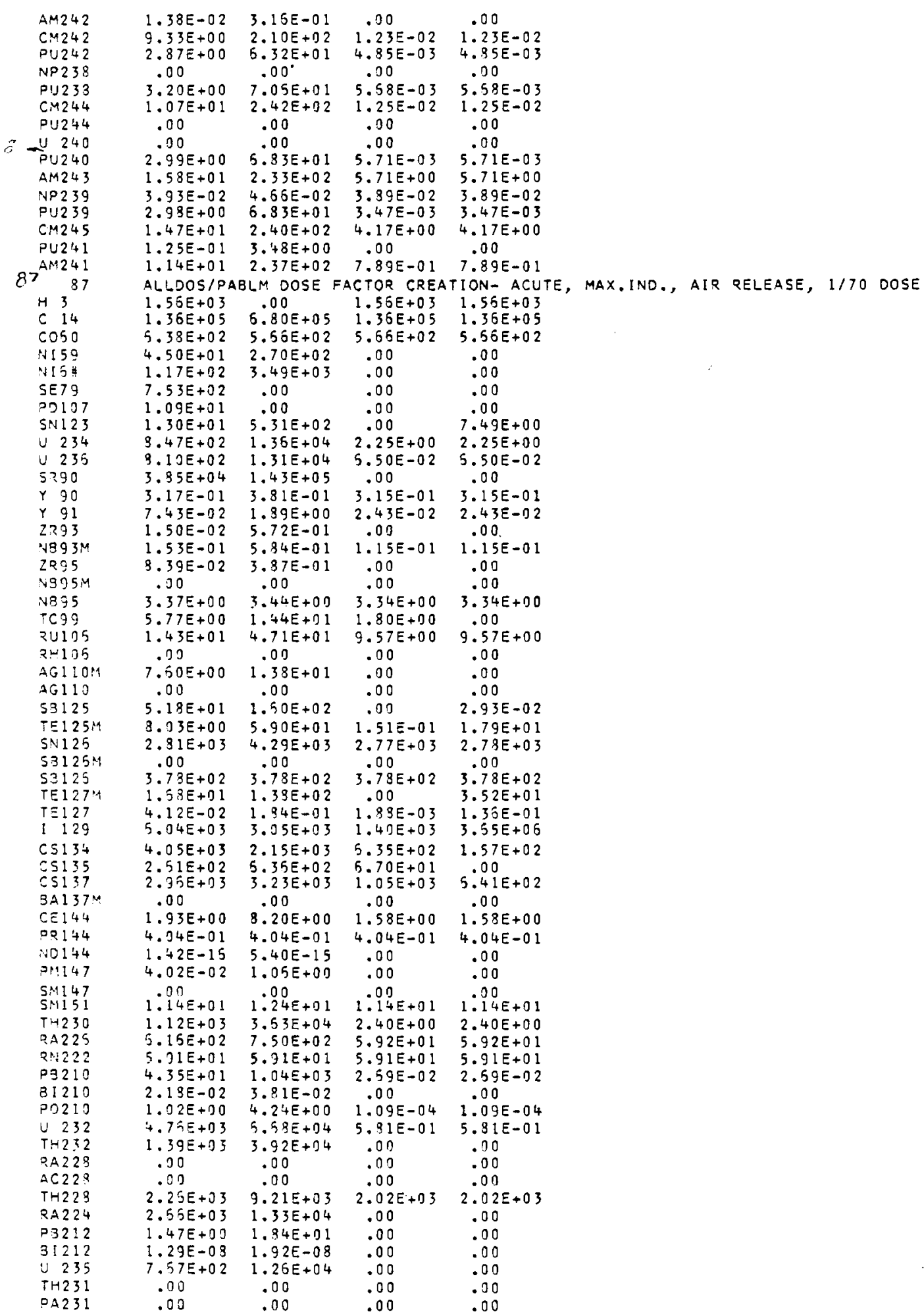

FIGURE C.0-3. File 12 Data Library 


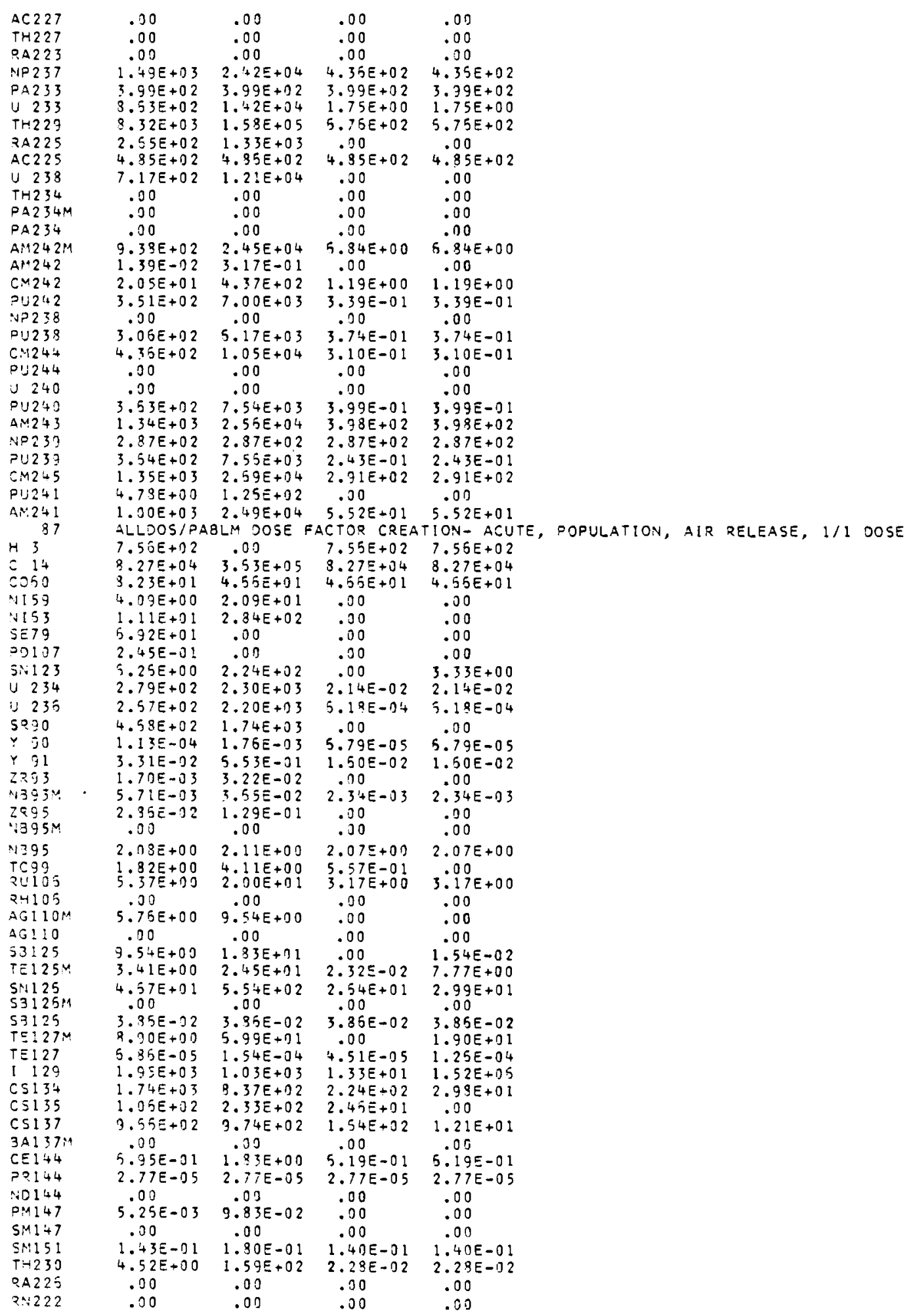

FIGURE C.0-3. File 12 Data Library 


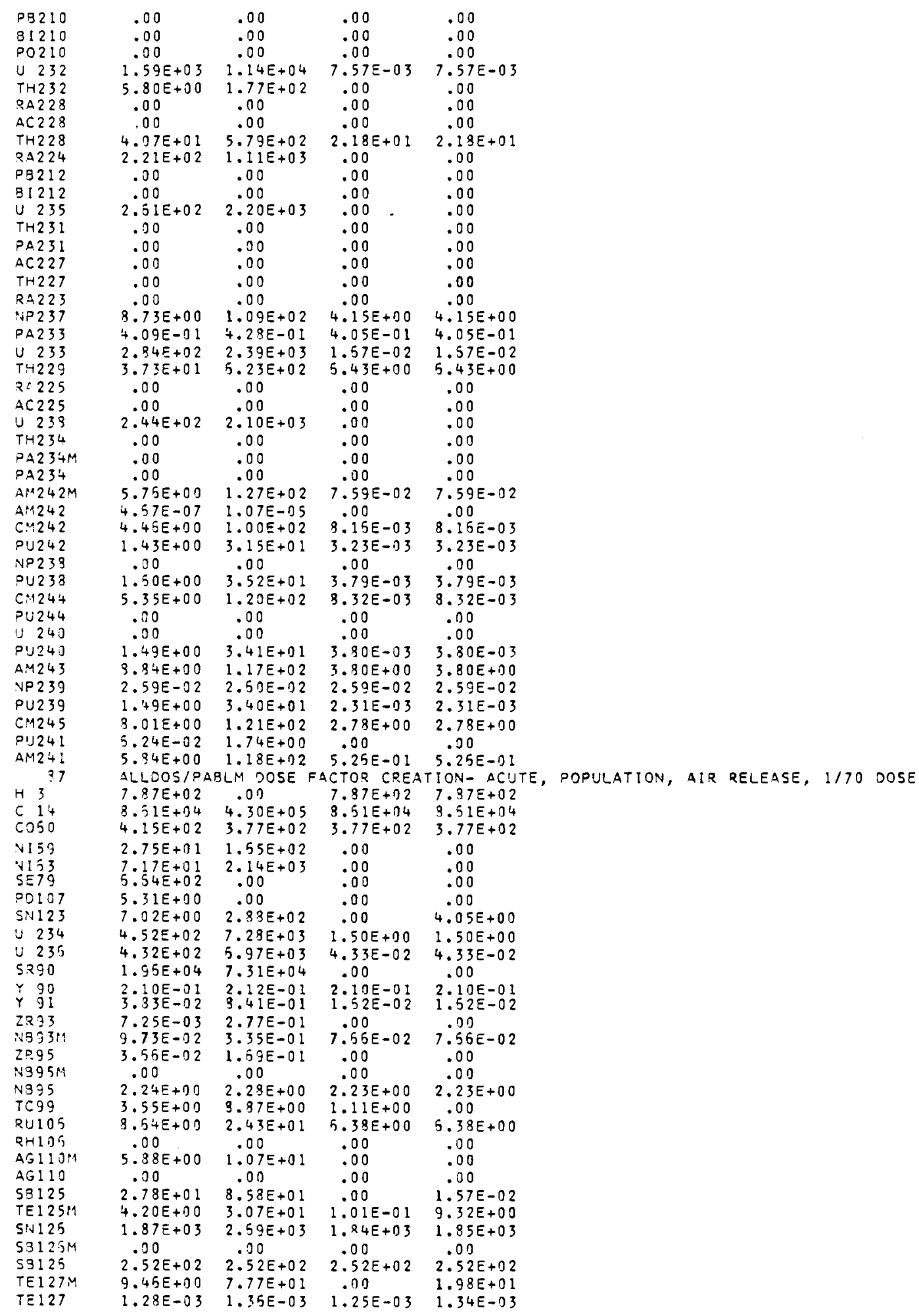

\section{FIGURE C.0-3, File 12 Data Library}




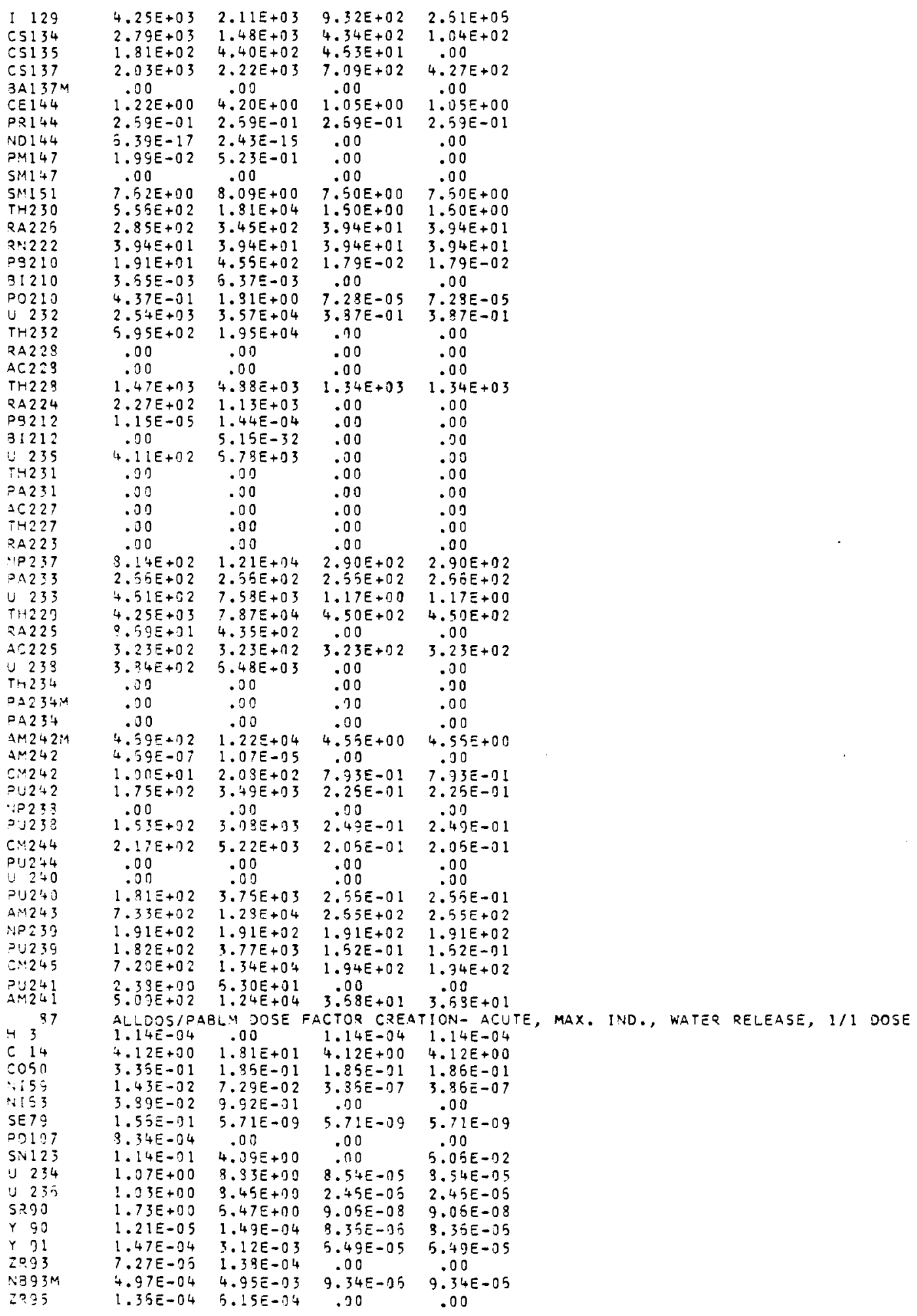

FIGURE C.0-3. File 12 Data Library 


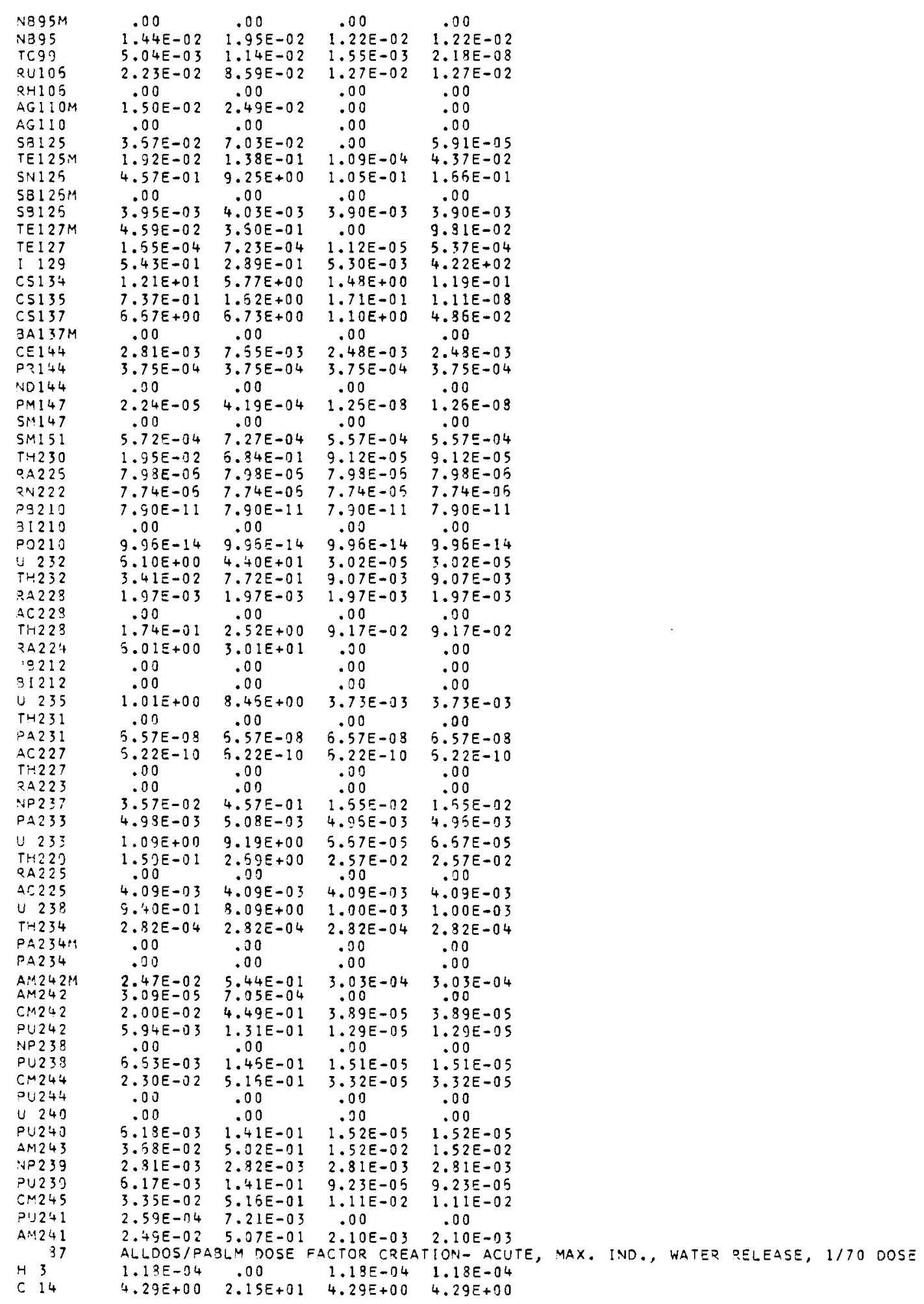

\section{FIGURE C.0-3. File 12 Data Library}




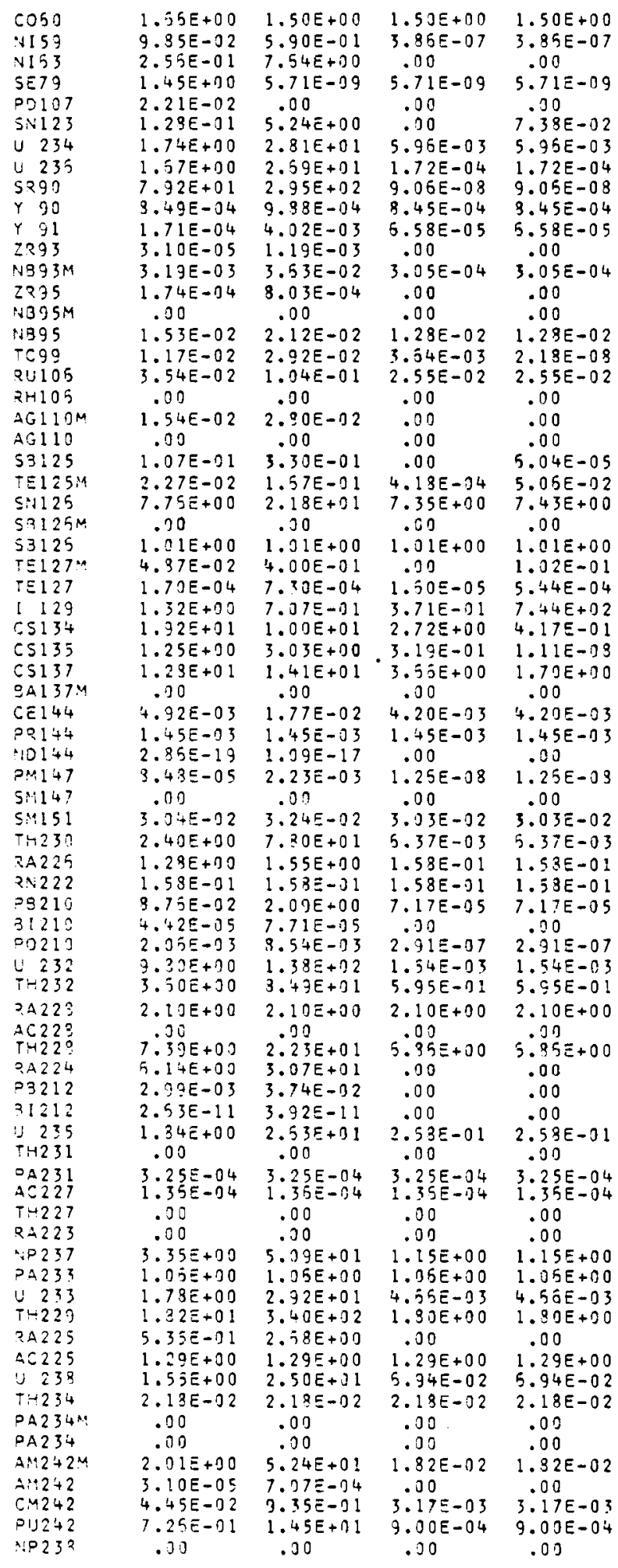

\section{FIGURE C.0-3. File 12 Data Library}




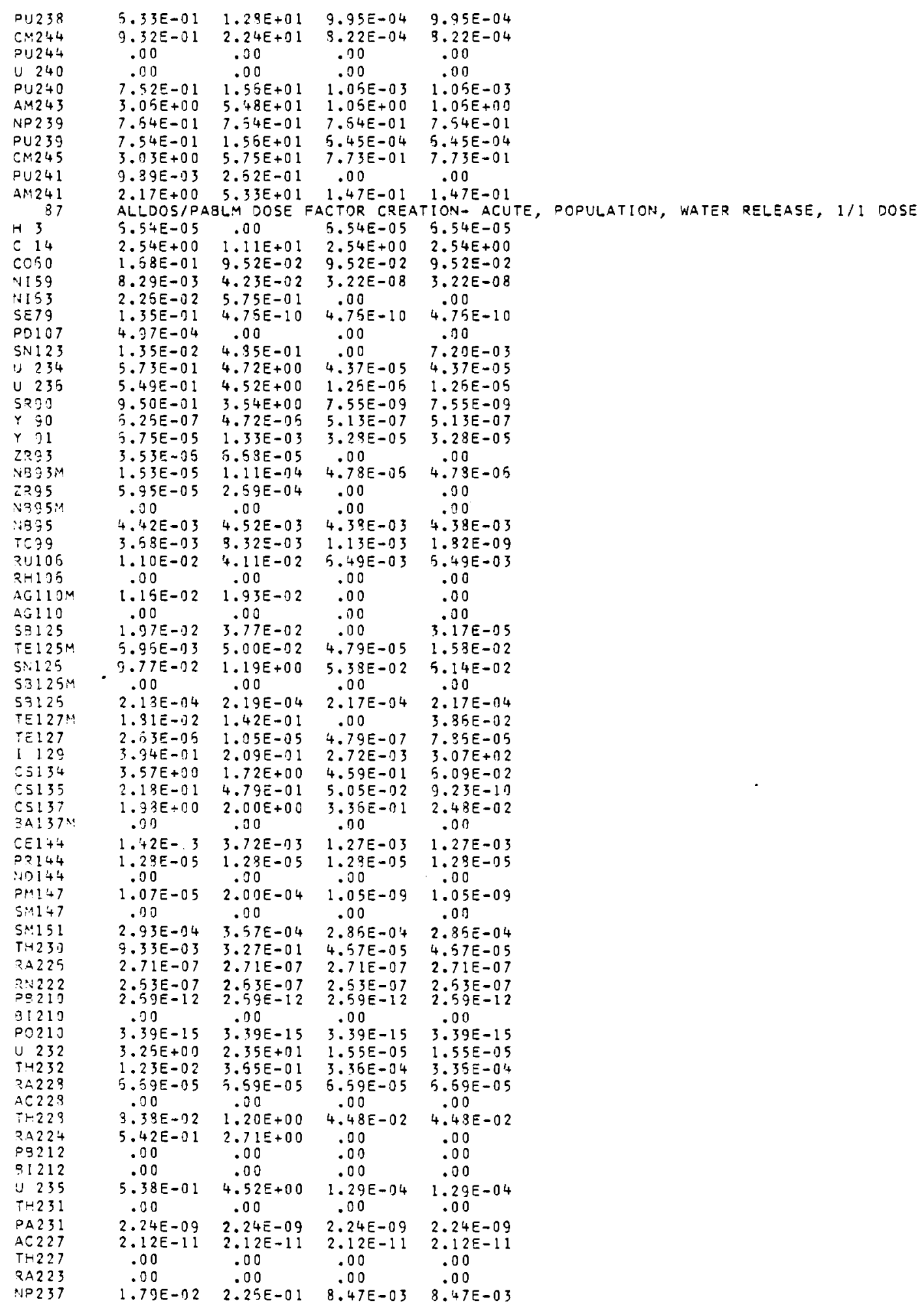

FIGURE C.0-3. File 12 Data Library 


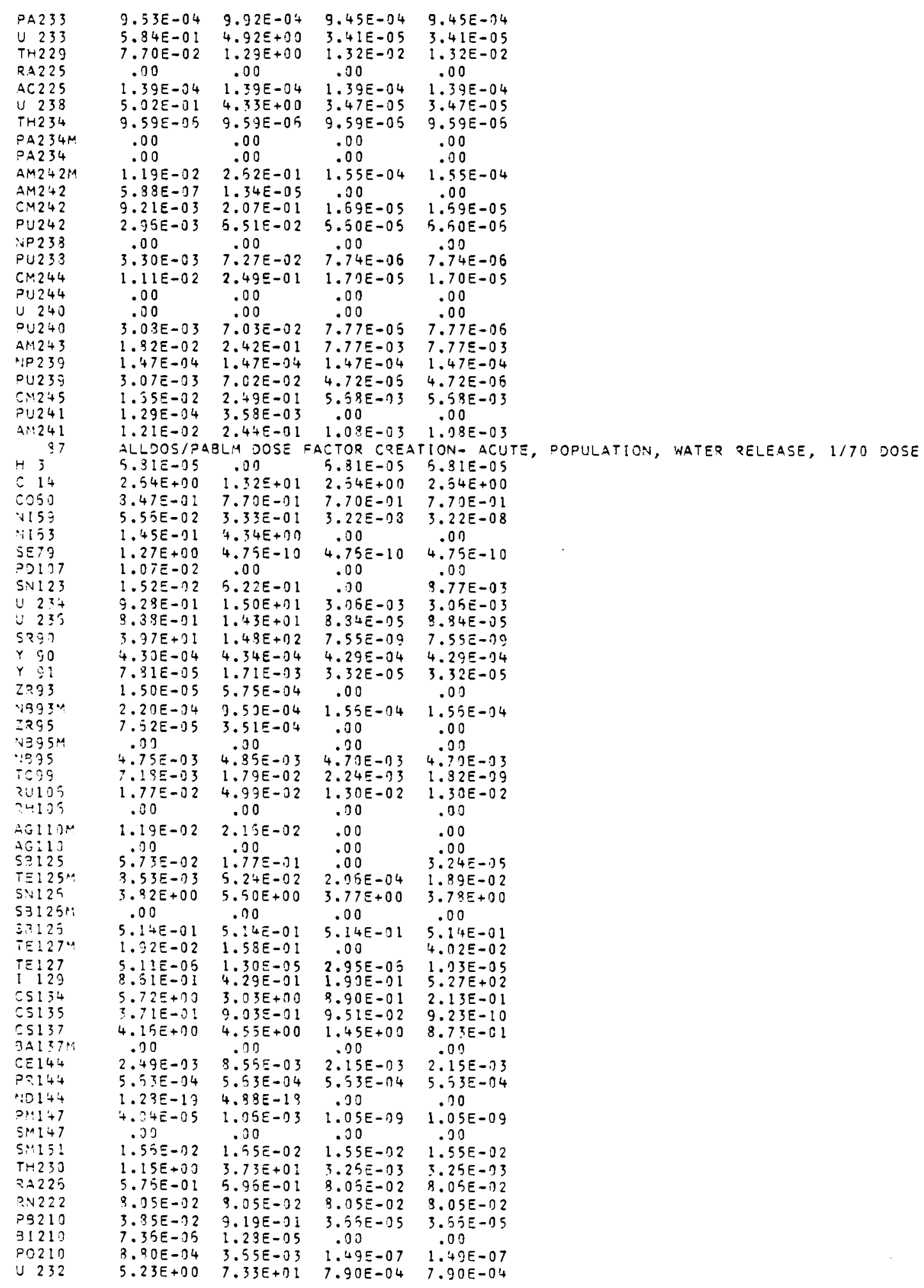

FIGURE C.0-3. File 12 Data Library 


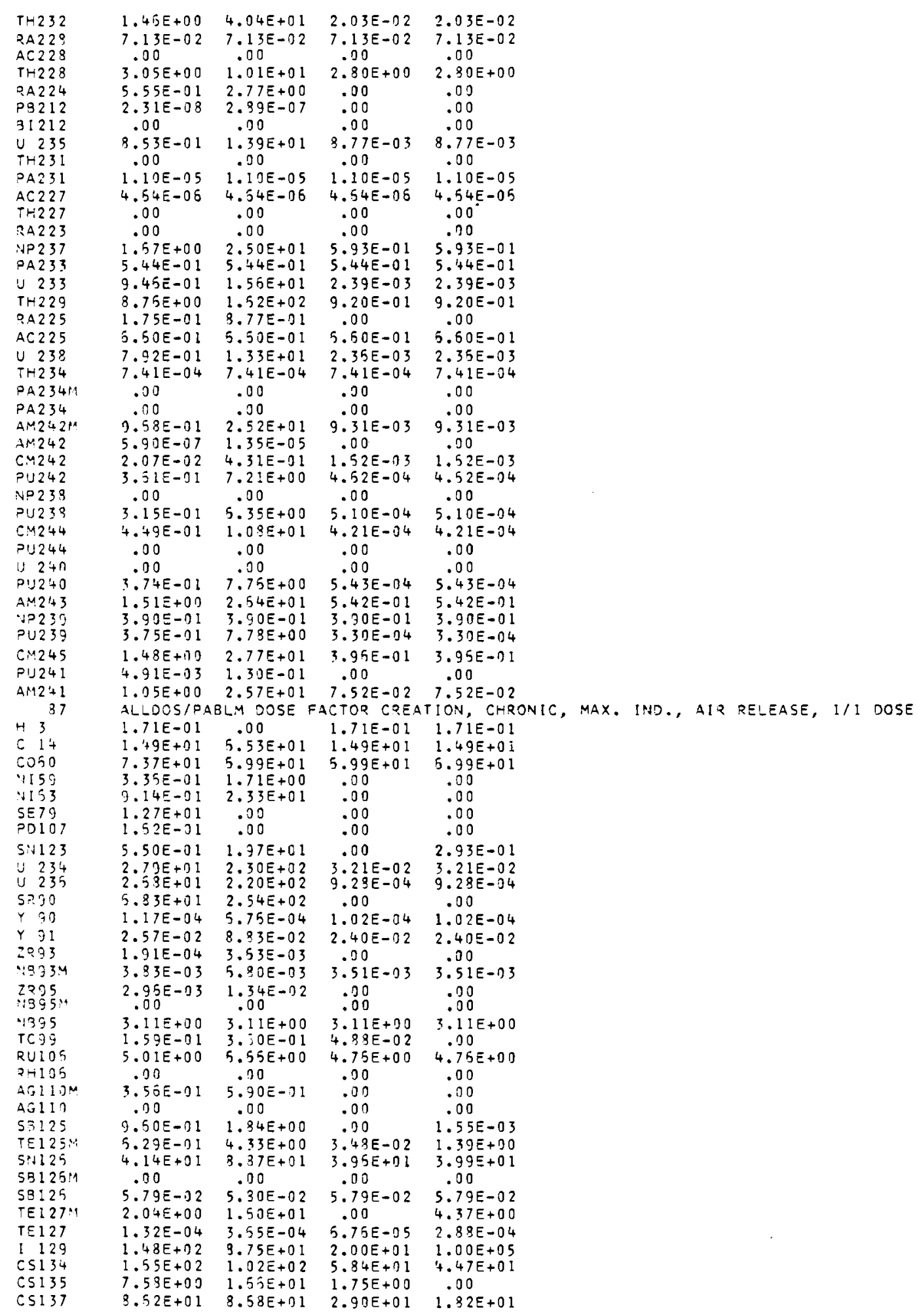

FIGURE C.0-3. File 12 Data Library 


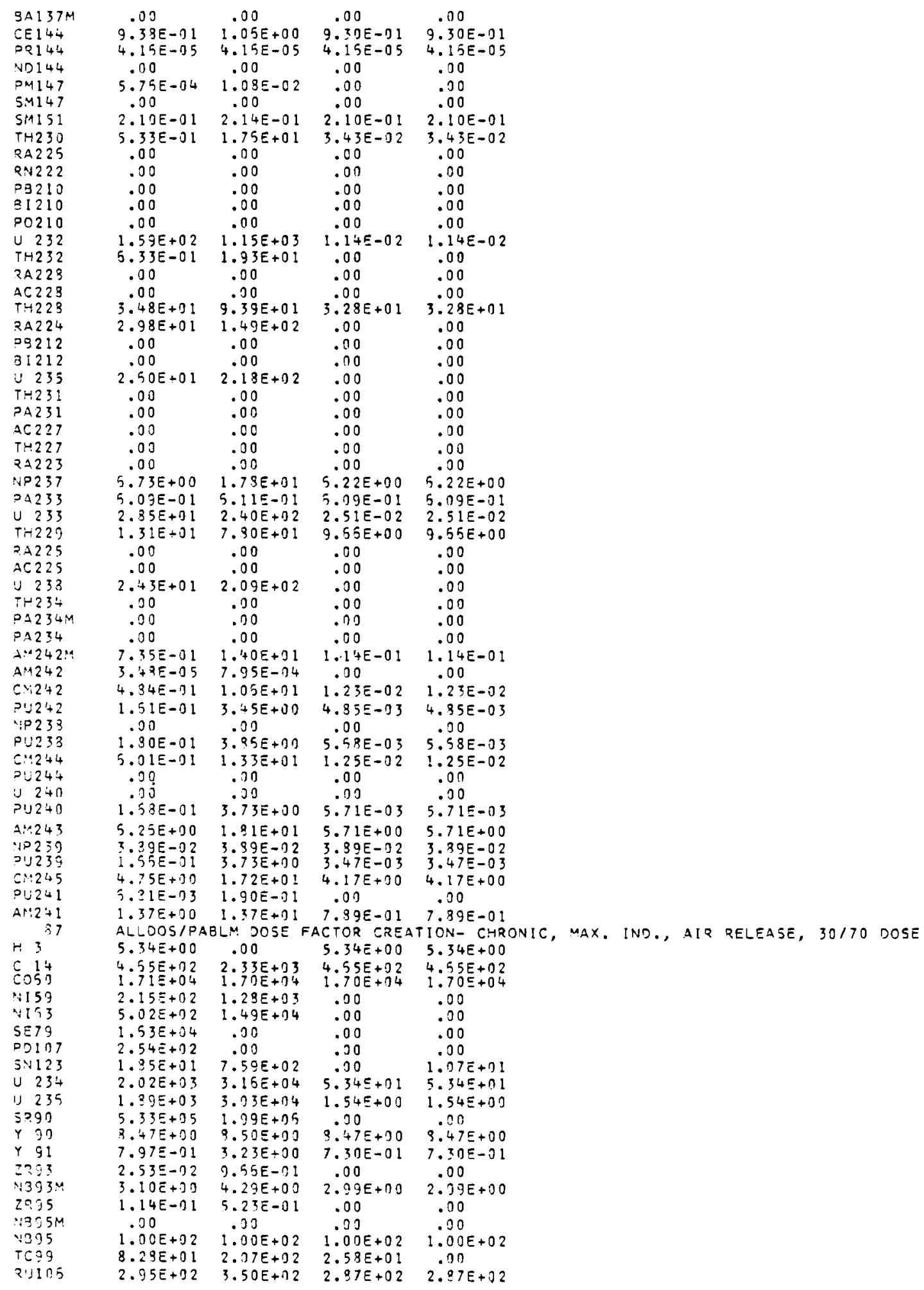

\section{FIGURE C.0-3. File 12 Data Library}




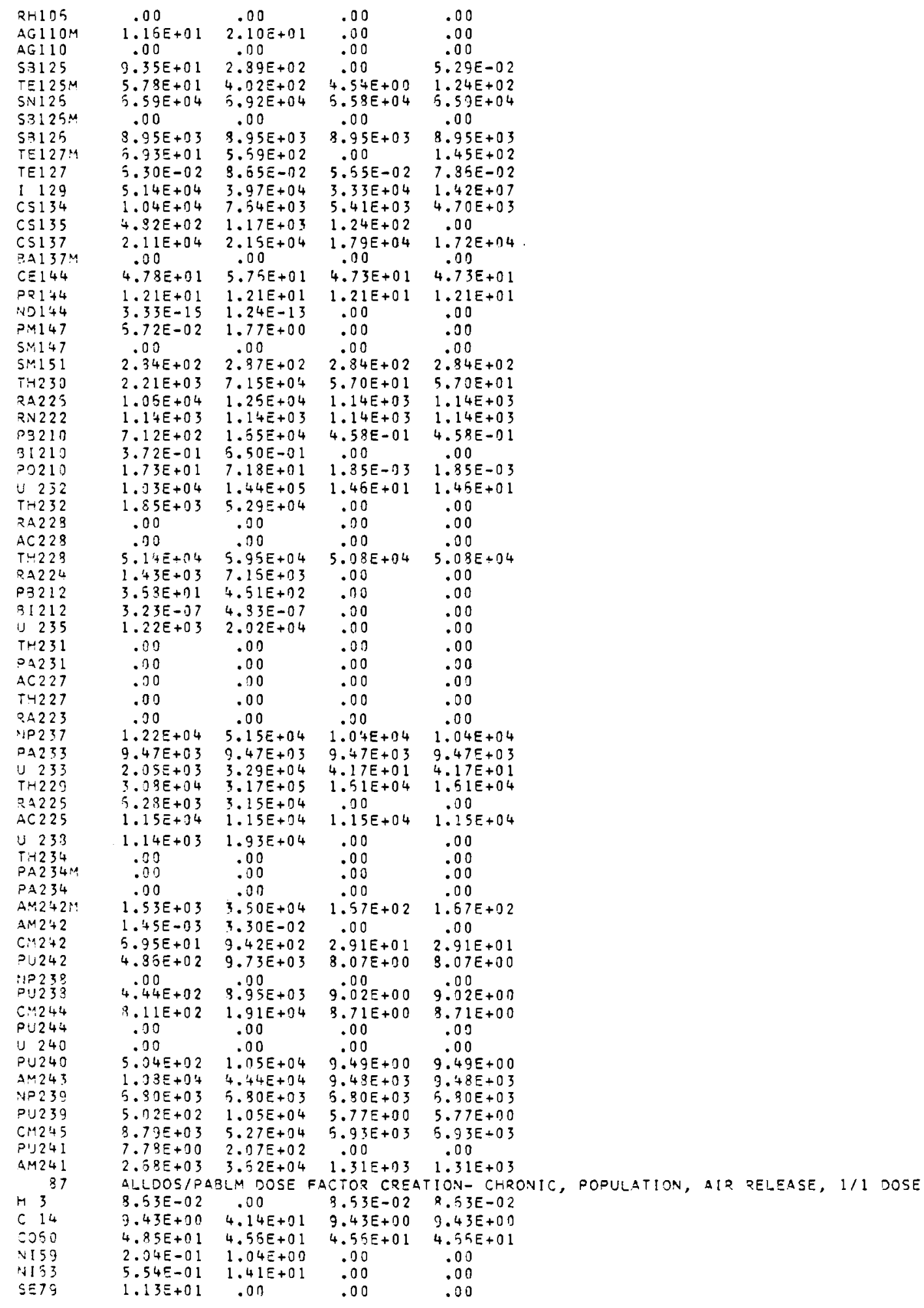

FIGURE C.0-3. File 12 Data Library 


\begin{tabular}{|c|c|c|c|c|}
\hline P0107 & $3.01 E-02$ & .00 & .00 & .00 \\
\hline $5 N 123$ & $2.91 E-31$ & 1. $0+E+71$ & .00 & $1.55 \varepsilon-01$ \\
\hline J 234 & $1 .+3 E+01$ & $1.21 E+02$ & $2.14 E-32$ & \\
\hline บ 235 & $1.41 E+01$ & $1.15 E+12$ & $5.19 E-04$ & $5.19 E-04$ \\
\hline 5230 & $3.51 E+01$ & $1.31 \bar{E}+72$ & .00 & .00 \\
\hline Y 30 & $=-35$ & $3.29 E-105$ & $5.79 E-05$ & $9 E-05$ \\
\hline Y 91 & $1.58 E-02$ & $4.4+3 E-J 2$ & $1.50 E=02$ & $1.50 E-02$ \\
\hline 2893 & 9.27 & $1.75 E-03$ & .00 & .00 \\
\hline $1993 \mathrm{~N}$ & 2.51 & $4.12 E-03$ & $2.34 E-03$ & $2.34 E-03$ \\
\hline 2235 & $1.29 E-03$ & $5.83 E-03$ & .00 & .00 \\
\hline$\therefore B 95 P$ & .00 & .00 & .00 & .00 \\
\hline NB95 & $2.07 E+10$ & $2.07 E+00$ & $2.07 E+00$ & $2.07 E+00$ \\
\hline $\operatorname{Tc9s}$ & $1.05 E-01$ & $2.39 E-01$ & $3.23 E-02$ & .00 \\
\hline २ण105 & $3.29 E+00$ & $4.08 E+00$ & $3.175+00$ & $3.17 E+00$ \\
\hline $2-105$ & .00 & .00 & .00 & .00 \\
\hline$A G 11014$ & $2.55 \bar{E}-01$ & $4.40 E-01$ & .00 & .20 \\
\hline$A G 1: 0$ & .00 & .00 & .00 & .00 \\
\hline 53125 & $5.04 E-01$ & $9.575-01$ & .00 & $8.13 E-0$ \\
\hline$T E 125 \mathrm{~N}$ & $3.19 E-91$ & $2.15 E+00$ & $2.325-02$ & $5.98 E-0$ \\
\hline $5 \times 125$ & $2.74 E+01$ & $5.33 E+101$ & $2.54 E+01$ & $2.55 E+0$ \\
\hline 5312519 & .00 & .0 & .00 & .00 \\
\hline 53125 & $3.95_{3} E-02$ & $3.35 E-02$ & $3.35 E-02$ & $3.95 E-0$ \\
\hline$T E 127: 4$ & $1.175+00$ & $8.39 E+00$ & .00 & $2.28 E+00$ \\
\hline TE 127 & $4.51 E-05$ & $4.52 E-05$ & $4.51 E-05$ & $4.52 E-05$ \\
\hline $1 \quad 129$ & $1.04 E+02$ & $5.1+E+01$ & $1.33 E+01$ & $7.15 E+04$ \\
\hline CS1:4 & $1.115+02$ & $5.32 E+01$ & $3.90 E+01$ & $2.98 E+01$ \\
\hline 65135 & $5.13 E+00$ & $1.13 E+01$ & $1.19 E+00$ & .00 \\
\hline $\operatorname{css} 137$ & $5.325+01$ & $5.8 F E+01$ & $1.95 E+01$ & $1.21 E+01$ \\
\hline $3 \Delta 137 ! 4$ & .30 & .30 & .00 & .00 \\
\hline 55144 & $5.23 E-01$ & $5.32 E-01$ & $5.19 E-01$ & $5.19 E-01$ \\
\hline 0.144 & $2.77 E-35$ & $2.77 E-05$ & $2.775-05$ & $2.77 E-05$ \\
\hline N214 14 & .00 & .00 & .00 & .00 \\
\hline$P M 147$ & $2.95 \bar{E}-104$ & $5.33 E-.73$ & .00 & .00 \\
\hline $5 M 1+7$ & .00 & .00 & .00 & .00 \\
\hline $5: 115 !$ & $1.40 E-01$ & $1+42 E-11$ & $1.40 E-01$ & $1.40 E-01$ \\
\hline $\begin{array}{l}1.231 \\
21225\end{array}$ & 2.71 & 9.738 & 2.256 & $\begin{array}{r}2.238 \\
000\end{array}$ \\
\hline ₹ 1225 & .00 & .00 & .00 & .00 \\
\hline $8: 1222$ & .00 & .00 & 00 & .00 \\
\hline P3210 & .00 & .00 & .00 & .00 \\
\hline 31210 & .30 & .00 & .00 & .00 \\
\hline 90210 & .00 & .00 & .00 & .00 \\
\hline U 232 & $3.3 G E+01$ & $5.05 E+02$ & $7.57 E-03$ & $7.57 E-0$ \\
\hline $5 \div 232$ & $3.15 \equiv-01$ & $9.53 E+100$ & .00 & .00 \\
\hline RA223 & .30 & .00 & .00 & .00 \\
\hline AC 228 & .00 & .00 & .00 & .00 \\
\hline$T 4222$ & $2.2 \subseteq E+D !$ & $5.20 E+01$ & $2.195+01$ & $2.18 E+01$ \\
\hline$\therefore A 224$ & $2 \cdot \tilde{J}+\tilde{E}+3)$ & $1.27 E+31$ & .00 & .00 \\
\hline $332: 2$ & .00 & .00 & .00 & .00 \\
\hline 31212 & .35 & .0 & .0 & .00 \\
\hline U) 235 & $1.375+01$ & $1.15 E+12$ & .0 & .0 \\
\hline$T+231$ & .00 & .00 & .00 & .00 \\
\hline PA231 & .00 & .00 & .00 & .00 \\
\hline 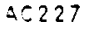 & .90 & .00 & .00 & .00 \\
\hline$T-227$ & .20 & .00 & - & .00 \\
\hline 24223 & .00 & תח. & .00 & .00 \\
\hline $\begin{array}{l}: 2237 \\
\therefore 4233\end{array}$ & $\begin{array}{l}4.40 E+00 \\
4.05 E-01\end{array}$ & $\begin{array}{l}9.93 E+00 \\
4.35 E-01\end{array}$ & $4.15 E+00$ & $\begin{array}{l}4.15 E+0 \\
4.05 E-0\end{array}$ \\
\hline U 233 & $1.50 E+01$ & $1.25 E+02$ & $1.57 \mathrm{E}$ & $1.57 E-0$ \\
\hline$T-229$ & 3. $1+E+00$ & $4.05 E \div 0 I$ & $5 .+3 E$ & $5.43 E+0$ \\
\hline$R A 225$ & .00 & .30 & .00 & .00 \\
\hline $2 C 225$ & .00 & .00 & .30 & .00 \\
\hline J 23? & $1.28 E+01$ & $1.10 E+n 2$ & .00 & .00 \\
\hline$T-234$ & .00 & .00 & .00 & .00 \\
\hline $04234 \mathrm{~m}$ & .00 & .00 & $.0 n$ & .00 \\
\hline 24234 &.$\cap 0$ & .20 & .30 & .70 \\
\hline$A M 2+2 M$ & $3.95 \varepsilon-01$ & $5.99 E+00$ & $7.59 E-02$ & $7.59 E-0$ \\
\hline $\operatorname{AM} 242$ & $1.13 E-99$ & $2.59 E-08$ & .00 & .00 \\
\hline$C M 242$ & $2.33 E-01$ & $5.08 E+00$ & $8.15 E-$ & $3.15 \Xi-0$ \\
\hline $\operatorname{P\cup } 2 \div 2$ & $3.12 E-32$ & $1.725+00$ & $3.23 E-03$ & $3.23 E-03$ \\
\hline NP 238 & .00 & .00 & .70 & .00 \\
\hline$P \cup 233$ & $9.07 E-32$ & $1.32 E+00$ & $3.79 \varepsilon-03$ & $3.79 E-0$ \\
\hline $\mathrm{CM} 24+$ & $3.01 \varepsilon-01$ & $5.51 E+100$ & $3.32 E-33$ & $3.32 E-0$ \\
\hline$P \cup 2 \div 4$ & .00 & .00 & .00 & .30 \\
\hline U] 240 & . 22 & .00 & .00 & .00 \\
\hline
\end{tabular}

FIGURE C.0-3. File 12 Data Library 


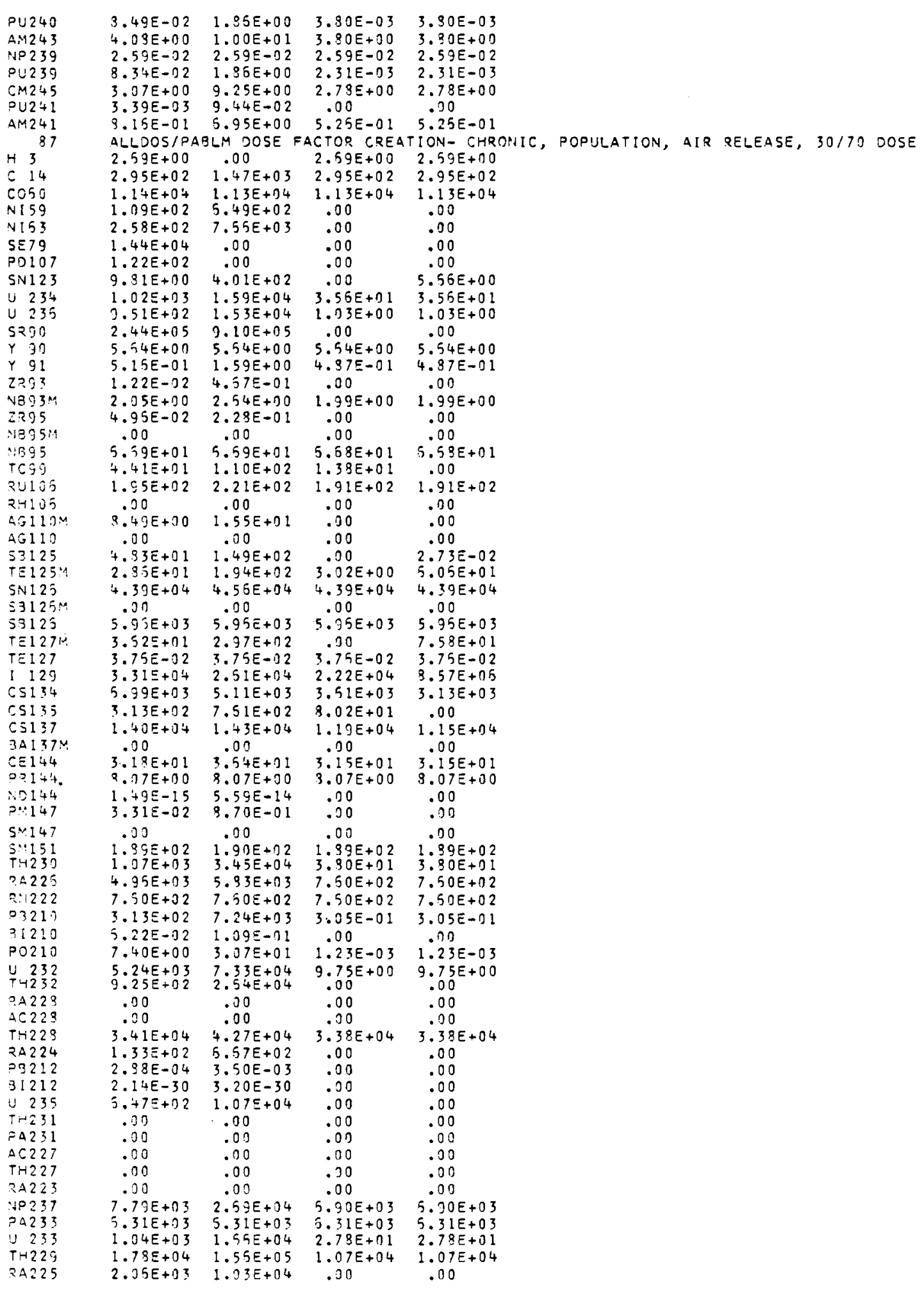

FIGURE C.0-3. File 12 Data Library 


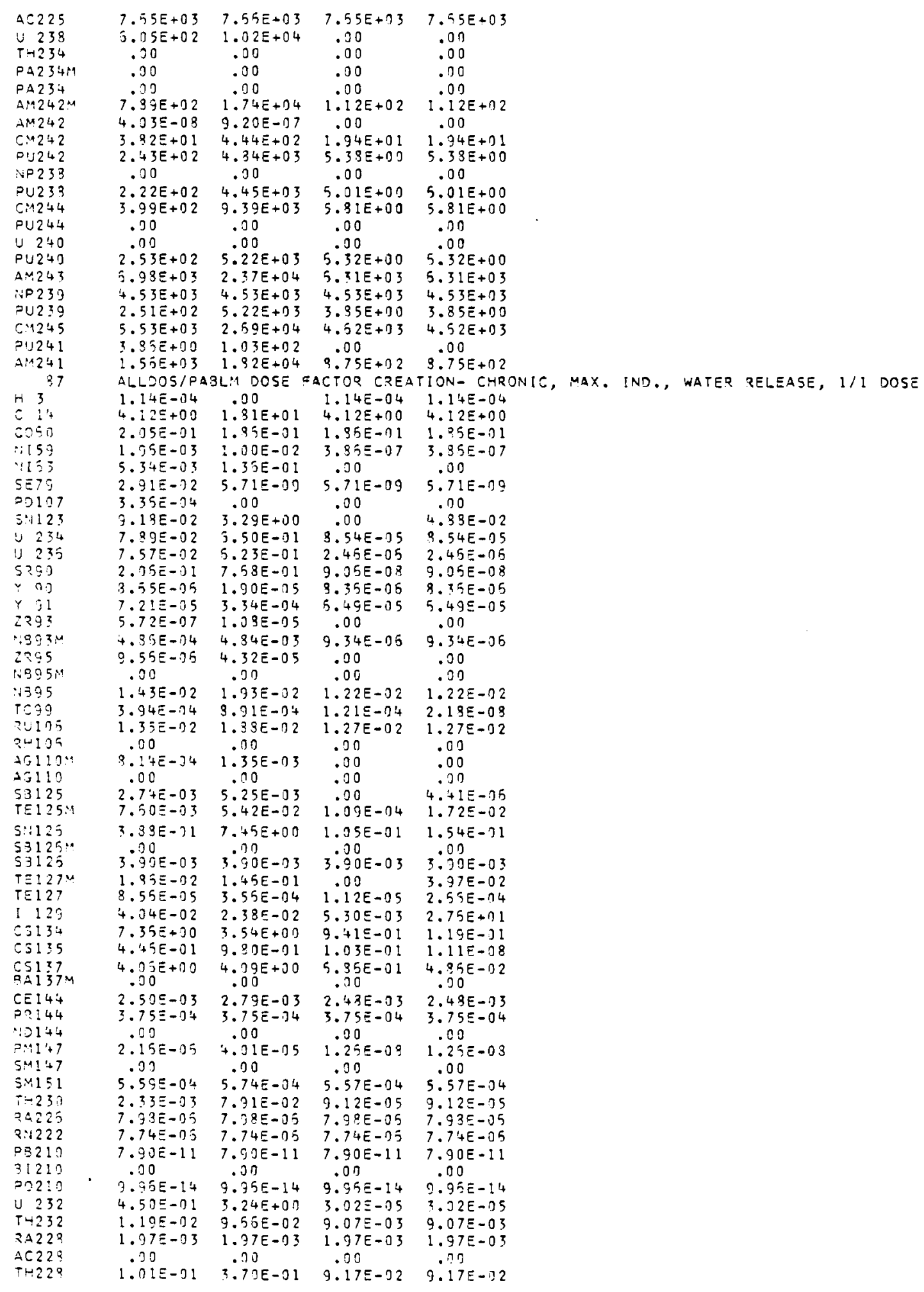

FIGURE C.0-3. File 12 Data Library 


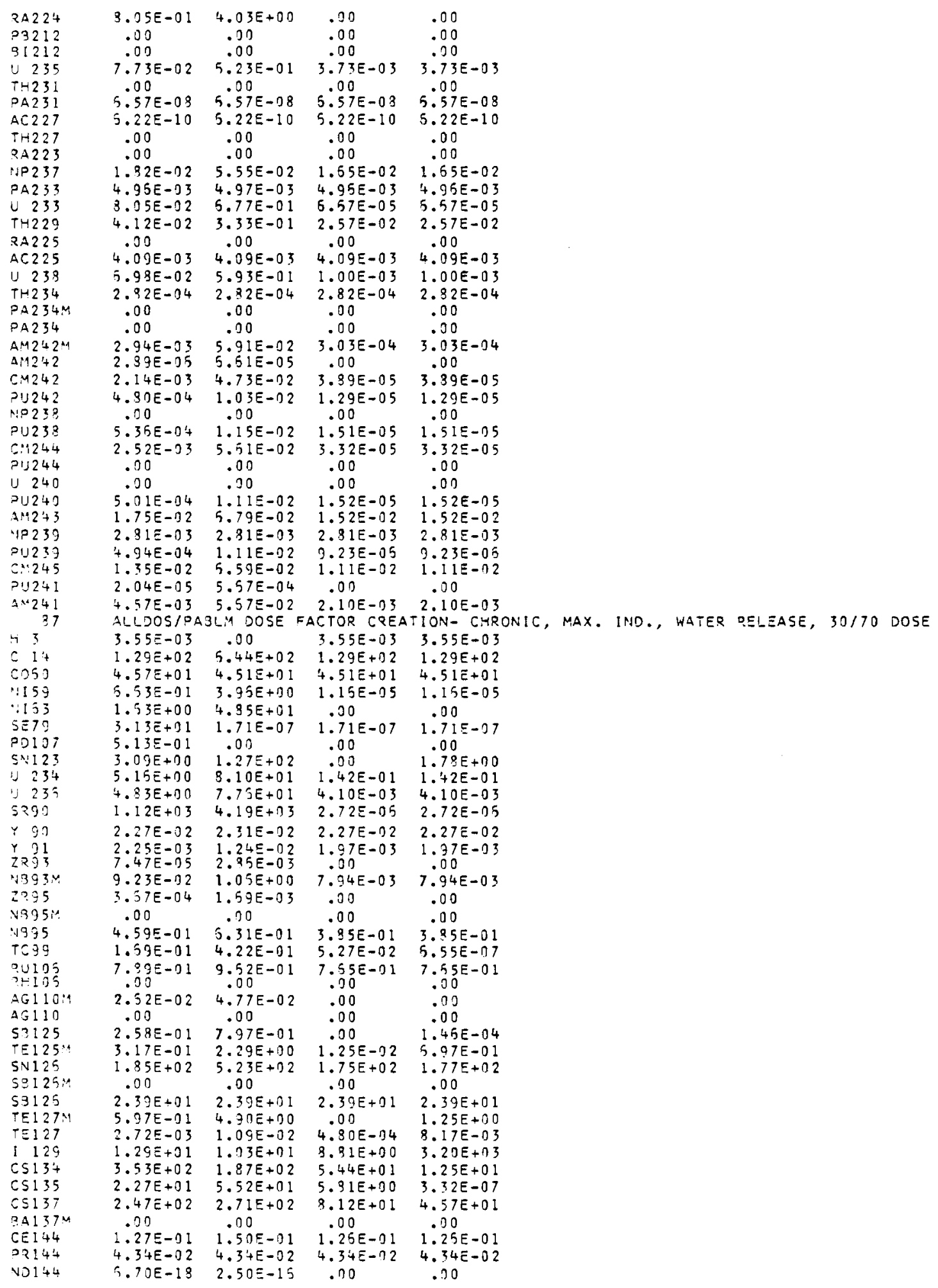

FIGURE C.0-3. File 12 Data Library 


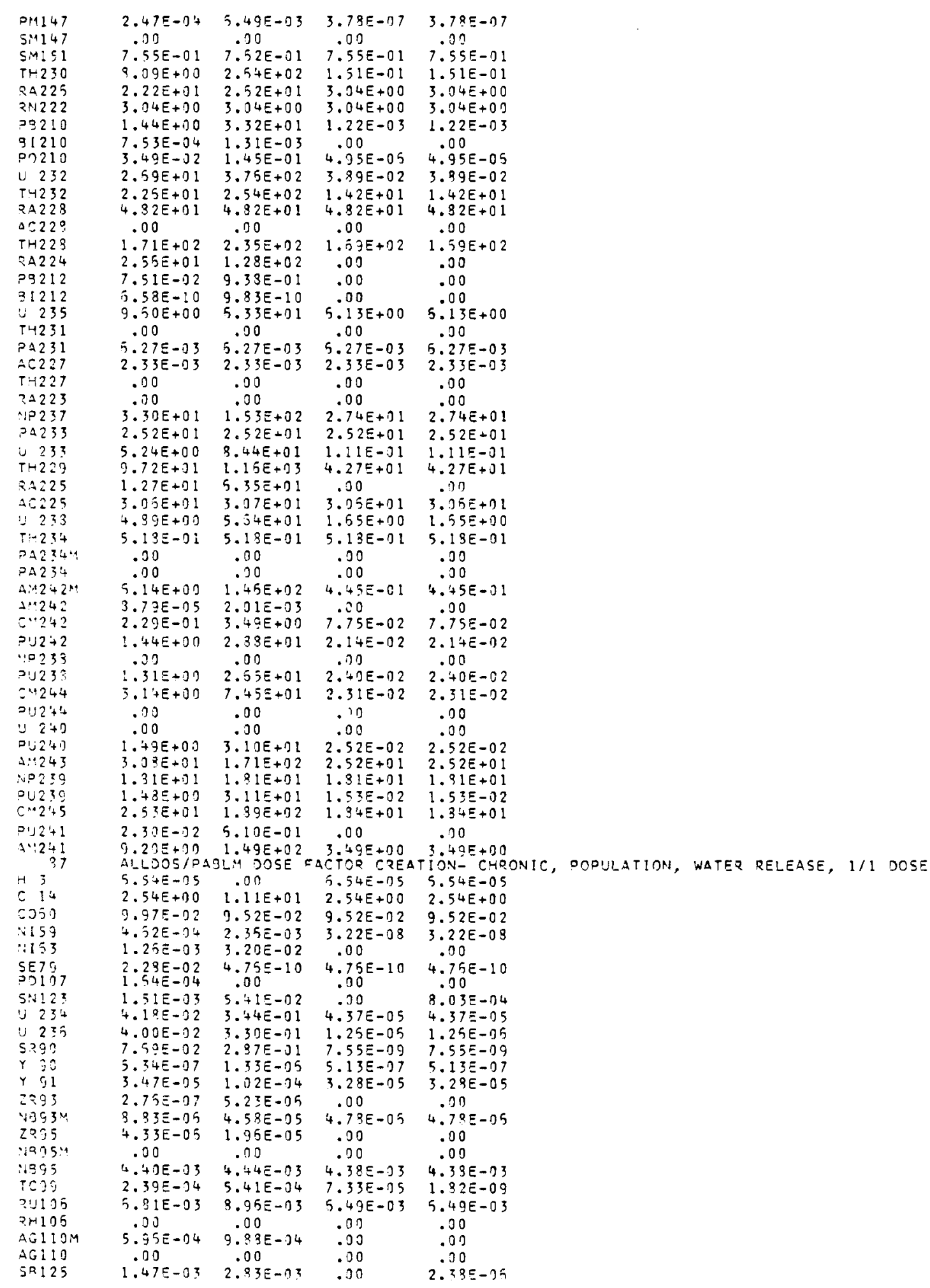

FIGURE C.0-3. File 12 Data Library 


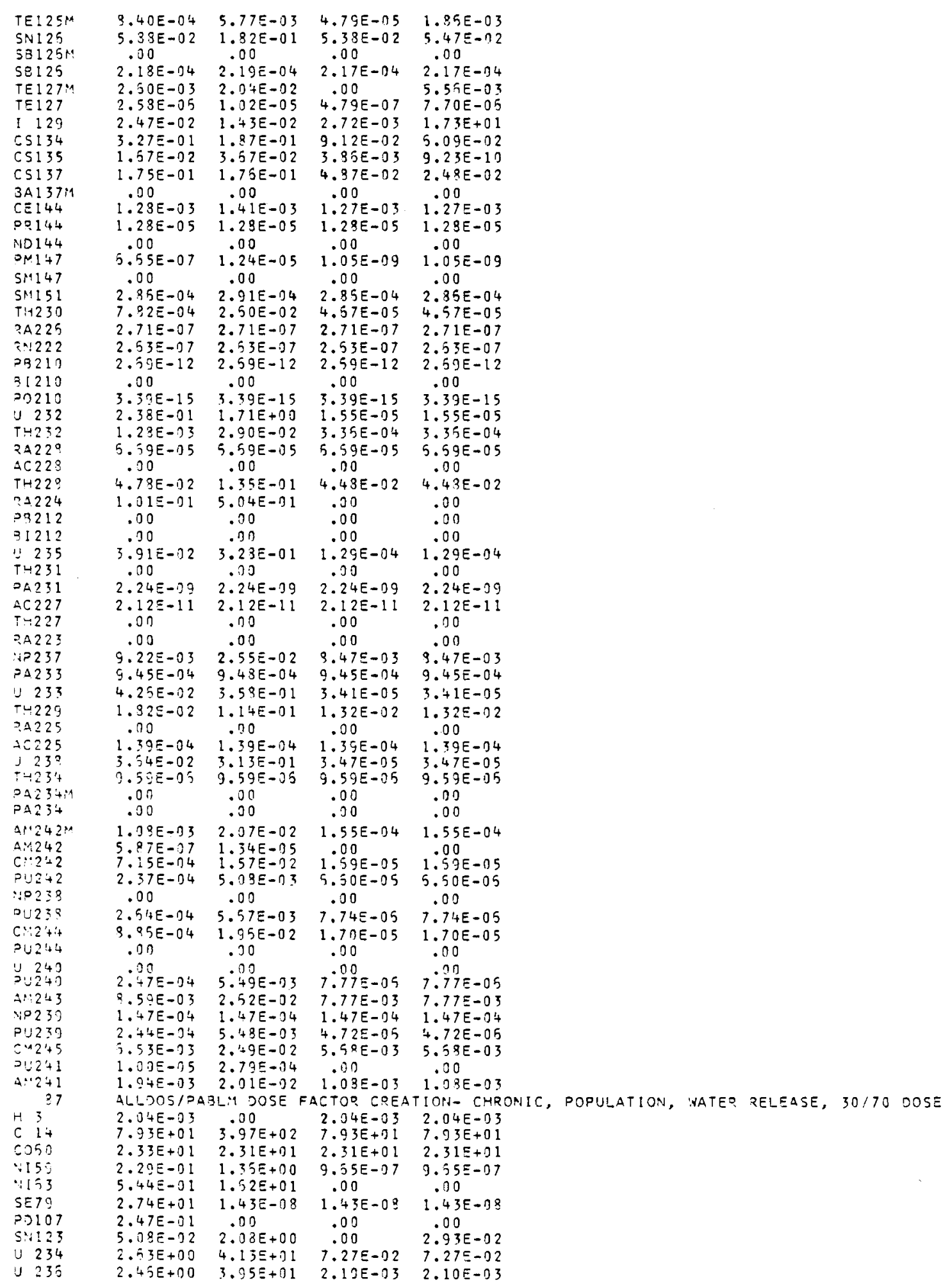

FIGURE C.0-3. File 12 Data Library 


\begin{tabular}{|c|c|c|c|c|}
\hline 5290 & $4.97 \equiv+02$ & $1.85 E+03$ & $2.27 E-07$ & $2.27 E-07$ \\
\hline Y 90 & $1.15 E-0.2$ & $1.15 E-02$ & $1.15 E-02$ & $1.15 E-12$ \\
\hline Y 91 & $1.07 E-33$ & $3.59 E-03$ & $9.97 E-04$ & $9.97 E-04$ \\
\hline 2293 & $3.50 E-05$ & $1.38 E-03$ & .00 & 01 \\
\hline$\therefore 3934$ & $4.83 E-03$ & $1.35 E-92$ & $4.07 E-03$ & $4.07 E-13$ \\
\hline 2295 & $1.55 E-74$ & $7.55 E-04$ & .00 & .00 \\
\hline$N E, 95 M$ & .00 & .00 & .00 & .00 \\
\hline : 995 & $1.42 E-91$ & $1.43 E-01$ & $1.41 E-01$ & $1.41 E-01$ \\
\hline TC99 & $9.97 E-02$ & $2.24 E-01$ & $2.79 E-12$ & $5 .+5 E-09$ \\
\hline 20105 & $4.01 E-01$ & $4.72 E-01$ & $3.91 E-01$ & $3.01 E-01$ \\
\hline SH105 & .00 & .00 & .00 & .00 \\
\hline$A G 1134$ & $1.90 E-02$ & $3.45 E-02$ & .00 & .00 \\
\hline$\Delta S 110$ & .00 & .00 & .00 & .00 \\
\hline $\begin{array}{l}\text { S.3125 } \\
T E 125 \mathrm{M}\end{array}$ & $\begin{array}{l}1.37 E-71 \\
5.34 E-92\end{array}$ & $\begin{array}{l}4.24 E \rightarrow 01 \\
4.34 E-91\end{array}$ & $\begin{array}{l}.00 \\
5.19 E-03\end{array}$ & $\begin{array}{l}7.75 E-05 \\
1.35 E-01\end{array}$ \\
\hline $\sin 125$ & $8.93 E+01$ & $9.55 E+01$ & $3.95 E+01$ & $3.97 E+01$ \\
\hline 5512514 & .00 & .00 & .00 & .00 \\
\hline 53125 & $1.22 E+01$ & $1.22 E+01$ & $1.22 E+01$ & $1.22 E+01$ \\
\hline$T E 127 M$ & $3.59 E-02$ & $7.13 E-01$ & .00 & $1.82 E-01$ \\
\hline$T E 127$ & $1.52 E-04$ & $3.92 E-04$ & $8.35 E-05$ & $3.05 E-04$ \\
\hline 1129 & $E+00$ & $5.37 E+00$ & $4.53 E+00$ & $E+03$ \\
\hline 63134 & $1.90 E+01$ & $1.29 E+01$ & $7.95 E+00$ & $5.49 \varepsilon+00$ \\
\hline$C 5135$ & $9.48 E=01$ & $2.31 \equiv+00$ & $2.43 E-01$ & $2.77 E-08$ \\
\hline 05137 & $3.15 E+01$ & $3.24 E+01$ & $2.43 E+01$ & $2.34 E+01$ \\
\hline 341374 & .00 & .00 & .100 & .00 \\
\hline CE144 & $5.505-02$ & $7.58 E-02$ & $5.4+E-02$ & $5.44 \varepsilon-02$ \\
\hline بُ+' & $1 . j 3 E-02$ & $1.69 E-02$ & $1.59 E-02$ & $1.59 E-02$ \\
\hline $101+4$ & $3.005-13$ & $1.12 E-15$ & .00 & .00 \\
\hline $9+1147$ & $7.595-05$ & $2.025=03$ & $3.15 E-08$ & $3.15 E-08$ \\
\hline $5141+7$ & .00 & .30 & .00 & .00 \\
\hline $\sin 151$ & $3.37 E-01$ & $3.895-01$ & $3.87 \bar{E}-01$ & $3.37 E-01$ \\
\hline TH230 & $2.95 E+00$ & $9.215+01$ & $7.75 E-02$ & $7.75 E-02$ \\
\hline 9.8225 & $1.30 E+01$ & $1.13 E+01$ & $1.55 \overrightarrow{\mathrm{c}}+00$ & $1.55 E+00$ \\
\hline $0: 1222$ & $1.55 \equiv+00$ & $1.55 E+00$ & $1.55 \mathrm{E}+00$ & $1.55 E+00$ \\
\hline$P 3210$ & $5.31 E-01$ & $1.45 E+01$ & $5.24 E=04$ & $5.24 \varepsilon=04$ \\
\hline 91210 & $1.25 E-14$ & $2.19 E-04$ & .00 & .00 \\
\hline 02211 & $1.49 E-72$ & $5.13 E-02$ & $2.52 E-75$ & $2.52 E-05$ \\
\hline y 232 & {$[.33 E+1] 1$} & $1.93 E+92$ & $1.99 E-172$ & $1.99 E-02$ \\
\hline$T+232$ & $3.23 \vec{z}+100$ & $7.99 E+01$ & $4.93 E-01$ & $+.93 E-01$ \\
\hline $9422 ?$ & $1.54 E+02$ & $1.5+E+100$ & $1.5+5+00$ & $1.54 E+00$ \\
\hline$A=229$ & .00 & .30 & .00 & .00 \\
\hline $\begin{array}{l}T+2239 \\
71224\end{array}$ & $\begin{array}{l}7.11 E+0 ! \\
3.13 E+90\end{array}$ & $\begin{array}{l}9.35 E+01 \\
1.59 E+1) 1\end{array}$ & $\begin{array}{l}7.03 E+91 \\
.00\end{array}$ & $\begin{array}{l}7.03 E+01 \\
.00\end{array}$ \\
\hline 73212 & $5.79 E-77$ & $7.24 E-05$ & .00 & .00 \\
\hline$=1212$ & .20 & .05 & .70 & .00 \\
\hline$\because 235$ & 2. $045+07$ & $3.155 \bar{E}+01$ & $2.095-01$ & 2. $09 E-01$ \\
\hline $2 \div 25 !$ & $2.13 E-0 \div$ & $2.13 \equiv-04$ & $2.13 E-0.4$ & $2.13 E-04$ \\
\hline$A C 227$ & $7 . G+E-05$ & $7.94 \bar{E}=0.5$ & $7.94 E-05$ & 7. $94 E-35$ \\
\hline$T+227$ & .00 & .00 & .00 & $\begin{array}{l}.90 \\
.00\end{array}$ \\
\hline 8.1223 & .00 & .00 & .00 & .00 \\
\hline$\because P 237$ & $1.55 E+11$ & $5.925+01$ & $1.41 E+01$ & $1.41 E+71$ \\
\hline$P A 233$ & $1.29 z+01$ & $1.295+01$ & $1.29 E+01$ & $1.29 E+01$ \\
\hline U 233 & $2.57 E+00$ & $4.30 E+01$ & $5.58 E-02$ & $5.59 E-02$ \\
\hline$T H 229$ & $4.09 E+01$ & $4.115+02$ & $2.13 E+01$ & $2.13 \varepsilon+01$ \\
\hline 84225 & $+.15 E+00$ & $2.085+01$ & .09 & .0 \\
\hline$A=225$ & 1.5 & $1.57 \mathrm{E}$ & 1.5 & 1. \\
\hline j 239 & $1.77 E+00$ & $2.30 E+J 1$ & $5.52 E-02$ & $5.52 E-02$ \\
\hline$T=234$ & $1.75 E-92$ & $1.75 E-02$ & $1.75 E-02$ & $1.75 E-02$ \\
\hline $0.23+4$ & .20 & .00 & .00 & .00 \\
\hline$P \triangle 23+$ & .30 & .00 & בד & .00 \\
\hline$A: \because: 242 M$ & $2.22 E+10$ & $5.12 E+01$ & $2.28 E-01$ & $2.29 E-01$ \\
\hline $2: 242$ & $1.77 E-05$ & $4.33 E-04$ & .00 & \\
\hline$c \div 2+2$ & $J .2+E-72$ & $1.23 \bar{E}+00$ & $3.95 E-02$ & $3.95 E-12$ \\
\hline$P \cup 2+2$ & 7. . $5 E-01$ & $1 .+2 E+1$ & $1.2 D E-02$ & $1.10 E-02$ \\
\hline $1023 ?$ & & 00 & .00 & .00 \\
\hline$P \cup 238$ & $5.4 ว E-01$ & $1.30 E+01$ & $1.23 E-02$ & $1.23 E-02$ \\
\hline$C: 12+4$ & $1.13 E+10$ & $2.55 E+01$ & $1.19 E-02$ & $1.19 E-02$ \\
\hline $0 \cup 244$ & & בח & . & .00 \\
\hline$U 2+10$ & .00 & .00 & .00 & .00 \\
\hline $9 \cup 240$ & $7.34 E-01$ & $1.53 \bar{E}+01$ & $1.29 \varepsilon-02$ & $1.29 E-72$ \\
\hline $2+243$ & $1.49 E+01$ & $5 .+1 \bar{E}+01$ & $1.29 E+01$ & $1.29 E+01$ \\
\hline$N P 239$ & $9.25 E+90$ & $9.25 \Xi+00$ & $9.25 E+00$ & $9.25 E+0 J$ \\
\hline$P \cup 239$ & $7.30 E-01$ & $1.53 E+71$ & $7.35 E-03$ & $7.35 E-03$ \\
\hline$C 1: 245$ & $1.19 E+01$ & $7.11 \equiv+01$ & $3.435+00$ & $9.43 E+00$ \\
\hline 00241 & $1.135-02$ & $3.90 E-01$ & .00 & .00 \\
\hline$A-2+1$ & $3.73 \bar{c}+00$ & $5.23 E+01$ & $1.79 E+00$ & $1.79 \overline{5}+09$ \\
\hline
\end{tabular}

FIGURE C.0-3. File 12 Data Library 
APPENDIX D

INPUT PREPARATION 


\section{INPUT PREPARATION}

This appendix describes input data card requirements and options for execution of ALLDOS. An input logic diagram is given in Figure D.0-1 which refers to the cards by card types. The card types are described below. The user is urged to refer to the logic diagram when preparing input to ensure proper order of the cards.

The first card for each case (card type 1) provides an 80 character descriptive title (8A10) to be printed in the heading of each output report. The next set of cards gives data for NAMELIST set INPUT. The first card of this set must begin with \$INPUT in columns 2-7 and the last card must end with \$END in any column except column 1. Each parameter is supplied by setting it equal to the desired value. For example, to set the prameter INV to 5 , enter INV $=5$ starting after column 8 on the first card. Array values are specified by including the array subscript. For example to set position 2 of array LORG to 6 enter LORG(2) $=6$. Each entry must be separated by a comma. The NAMELIST INPUT parameters recognized by ALLDOS are described below.

Parameter (Dimension)

NREL

IPATH
Description

Number of release pathways to be considered, $1 \leq$ NREL $\leq 3$. When NREL is 2 , the waterborne pathway is not considered and when NREL is 1 only the airborne pathway is considered. NREL is used mainly for input of release activities from cards (type 2). Use of NREL should be coordinated with IPATH.

Release pathway selection index. IPATH = 1 for airborne and terrestrial pathways

IPATH $=2$ for waterborne pathway on $1 y$ IPATH $=3$ for all three pathways 


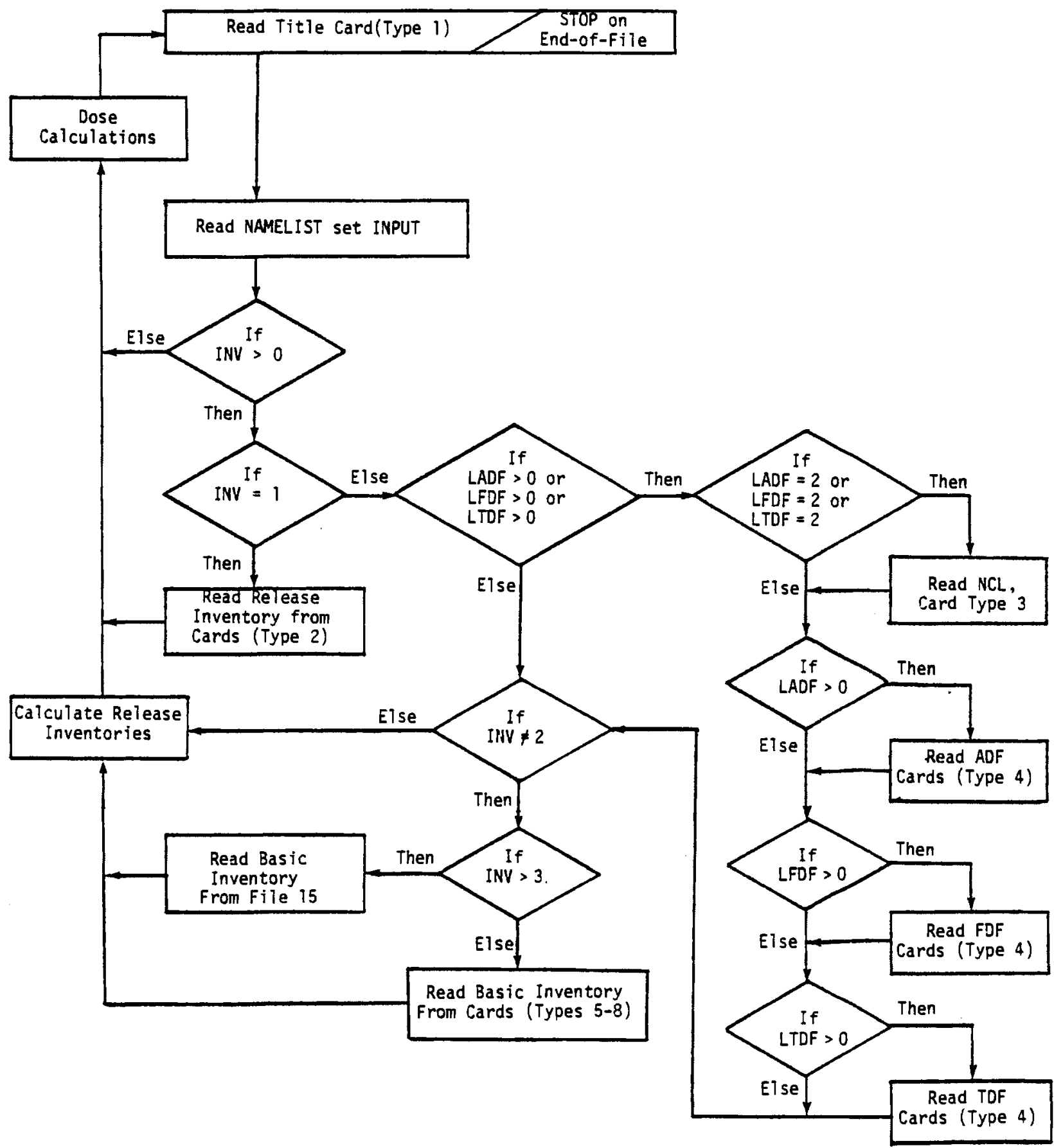

FIGURE D.0-1. ALLDOS Input Logic 
Parameter (Dimension)

LR

LPOP

LFCT

LM

$L Y$

LADF

LFDF
Description

Release type control integer:

$L R=1$ for acute release,

$L R=2$ for chronic release .

Population dose calculation control integer: LPOP $\leq 0$ skip population doses LPOP $>0$ calculate population doses.

Control integer for printing special output reports:

LFCT < print no special reports,

LFCT $=1$ print fractional contribution reports,

LFCT $=2$ print dose per radionuclide reports,

LFCT $=3$ print both of above.

Maximum individual dose calculation control integer:

LM $<0$ skip maximum individual doses,

LM $>0$ calculate maximum individual doses.

Control integer for calculation of the second dose commitment period doses. When $L Y=3$, the prolonged release dose conversion factors for inhalation are used for acute and chronic releases $(L R=1$ or $2)$. For acute releases the inhalation dose conversion factors are multiplied by a factor of 1.52 to correct for ventilation rate differences between acute and chronic uptake. LY has no effect when not equal to 3 .

Control integer for input of airborne pathway release factors:

LADF < 0 skip release factor input LADF $>0$ read airborne release factors LADF $=2$ read number of $c$ lasses, card type 3

Control integer for input of terrestrial pathway release factors:

LFDF $<0$ skip release factor input

LFDF $>0$ read terrestrial release factors

$\mathrm{LFDF}=2$ read number of $\mathrm{classes, \text {card }}$ Type 3 
Parameter (Dimension)

LTOF
Description

Control integer for input of waterborne pathway release factors:

LTDF < skip release factor input

LTDF $>0$ read waterborne release factors

$\mathrm{LTOF}=2$ read number of classes, Type 3

NOTE: only one card of Type 3 will be read for a case, even if more than one of the above control parameters are set to 2 .

NRN

INV

$\operatorname{LORG}(5)$

PM

FPM

PFLOW
Number of radionuclides in the release inventory read from cards:

$1 \leq N R N \leq 100$ when INV $=1$.

Release inventory specification control integer:

INV $\leq 0$ uses previous inventory, no input, INV $\equiv 1$ read release inventories from cards (Type 2)

INV $=2$ calculate release inventories from previous basic inventory using new release factors

INV $=3$ read basic inventory from cards (Types 5-8) and calculate release using release factors

INV $>3$ read basic inventory from File 15 using inventory set INV-3 and calculate release using release factors

Organ selection array for this case. Values of LORG must be taken from values in the array IORG as read from the master data file in Unit 10. The values of LORG must also correspond to organs for which data is provided in the terrestrial and waterborne dose conversion factor data file on Unit 12 (see Appendix B).

Population weighted air transport factor for airborne pathway, $\mathrm{PM}_{\mathrm{a}}, \mathrm{man} \cdot \mathrm{sec} / \mathrm{m}^{3}$.

Population weighted air transport factor for the terrestrial pathway, $\mathrm{PM}_{t}$, $\mathrm{man} \cdot \mathrm{sec} / \mathrm{m}^{3}$.

Population environmental transport factor for the waterborne pathway, $F_{p}$, $\operatorname{man} \cdot \mathrm{sec} / \mathrm{ft}^{3}$. 
Parameter (Dimension)

XQM

FXQM

FLOW

TC
Description

Maximum individual time-integrated air concentration for the airborne pathway, $(E / Q)_{a}, \sec / \mathrm{m}^{3}$.

Maximum individual time-integrated iar concentration for the terrestrial pathway, $(E / Q)_{t}, \sec / \mathrm{m}^{3}$.

Maximum individual environmental transport factor for the waterborne pathway, $F_{m}$, $\mathrm{sec} / \mathrm{ft}^{3}$.

Plant life factor based on the release duration, years. If $T C$ is less than or equal to 0 then it is set to 1.0 .

The remaining input cards are determined by values of control parameters INV, LADF, LTDF and LFDF as indicated in the input logic flow diagram (Figure $0.0-1)$. The remaining card types are described below.

Card Type Columns Format

$2 \quad 1-8$

$9-10 \quad 2 x$

$11-20 \quad E 10.1$

Parameter Description

AREC, radionuclide name for which release terms on this card will be assigned.

Blank

QT(1), activity released to the airborne pathway, curies.

21-30 E10.1 QT(2), activity released to the terrestrial pathway, curies.

31-40 E10.1 QT(3), activity released to the waterborne pathway, curies.

Note: NRN cards of this type are read when INV - 1.

$3 \quad 1-2$

12

NCL, number of radionuclide classes to be used for this case, $1 \leq N C L \leq 80$.

Note: One card of this type is read when any of the parameters LADF, LTDF or LFDF is equal to 2 and INV $>1$.

4 1-2 I2 $\quad$ IC, radionuclide class index for the release fraction on this card, $1 \leq \mathrm{IC} \leq \mathrm{NCL}$. 

Card Type Columns Format Parameter Description
3-10 E8.1
DF(IC), release fraction for this radionuclide class.

Note: Cards of this type are read until a value for IC greater than 80 is encountered.

5 1-3 I3 NQ, number of radionuclide entries in this card set, $1 \leq \mathrm{NQ} \leq 350$.

$\begin{array}{llll}\begin{array}{l}4-11 \\ 11-60\end{array} & \begin{array}{l}7 X \\ 5 A 10\end{array} & \begin{array}{l}\text { Blank } \\ \text { OSET(5), description title for this basic } \\ \text { inventory. }\end{array} \\ 7 & 1-3 & \text { I3 } & \begin{array}{l}\text { NCLS, number of radionuclide classes to be } \\ \text { defined for this basic inventory, } 1 \leq N C L S \leq 80 .\end{array} \\ 1-3 & \text { I3 } & \begin{array}{l}\text { ICLS, radionuclide class index for the class } \\ \text { named on this card. }\end{array} \\ 11-20 & \text { AlO } & \begin{array}{l}\text { Blank } \\ \text { DFNAM(ICLS), descripive name for radionucide } \\ \text { Class ICLS. }\end{array}\end{array}$

Note: NCLS cards of Type 7 are read.

$8 \quad 1-8 \quad A 8$

$A Q(i)$, radionuclide name for activity on this card. Names must be taken from the master list on the File 10 library.

9-10 I2 ICL(i), radionuclide class this radionuclide is assigned to, $1 \leq \mathrm{ICL}(i) \leq \mathrm{NCL} \leq \leq 80$.

11-20 E10.1 SQ(i), activity of this radionuclide in the basic inventory, curies.

Note: NQ cards of Type 8 are read. Cards of Type 5-8 are read as a set when INV is 3 . 
APPENDIX E

SAMPLE PROBLEM 
This appendix illustrates use of the computer program ALLDOS. Necessary input to the computer programs DACRIN and PABLM are presented for generation of dose conversion factor parameters.

A two-part sample problem is described showing use of ALLDOS for acute and chronic releases. Use of File 15 for inventory specification is also illustrated.

\section{E.1 Sample Problem Description}

The sample problem has two cases to illustrate selection of several

options. Input parameters for each case are listed in Table E.1-1. The first case is to exercise the following features:

- acute release $(L R=1, L Y=0, T C=1)$

- airborne and terrestrial pathways (NREL $=2$, IPATH $=1$ )

- population dose calculation (LPOP $=1$, PM, FPM)

- maximum individual dose calculation ( $L M=1, X Q M$, FXOM)

- release inventory from cards (INV $=1$, NRN $=5$ )

- four organs; total body, bone, lungs, thyroid $(\operatorname{LORG}(1)=1,6,8,16)$

The second case is to be executed immediately after the first case in the same run. Only those parameters to be changed need be specified. The features exercised in the second case are:

- chronic release for 30 years ( $L R=2, L Y=3, T C=30)$

- all three pathways (NREL $=3$, IPATH $=3$ )

- population and maximum individual dose calculation (no change)

- inventory from File 15 (INV $=5, \operatorname{LADF}=2, \operatorname{LTDF}=1, \operatorname{LFDF}=1$ )

- new dispersion parameters (PM, FPM, PFLOW, XQM, FXQM, FLOW)

- same organs

The second case uses a basic inventory set from File 15. The file for this sample problem is described in Section E.4. The second inventory set from this file is to be used (INV $=3+2+5$ ) which is labeled "Decay for 5 years, basic inventory 2". There are three radionuclide classes for this library so the parameter on card Type 3 is set to 3 (NCL). A listing of the card input is given in Figure E.1-1. 
TABLE E.1-1 Sample Problem Input Parameters

\begin{tabular}{|c|c|c|}
\hline Parameter & Case 1 & Case 2 \\
\hline $\begin{array}{l}\text { NREL } \\
\text { IPATH } \\
\text { LR } \\
\text { LY } \\
\text { LPOP } \\
\text { LM } \\
\text { LFCT } \\
\text { LADF } \\
\text { LTDF } \\
\text { LFDF } \\
\text { NRN } \\
\text { INV } \\
\text { LORG(1) } \\
\text { PM } \\
\text { FPM } \\
\text { PFLOW } \\
\text { XQM } \\
\text { FXQM } \\
\text { FLOW } \\
\text { TC }\end{array}$ & $\begin{array}{l}2 \\
1 \\
1 \\
0 \\
1 \\
1 \\
0 \\
0 \\
0 \\
0 \\
5 \\
1 \\
1,6,8,16 \\
2.0 \mathrm{E}-3 \\
2.0 \mathrm{E}-3 \\
0 \\
1.0 \mathrm{E}-4 \\
5.0 \mathrm{E}-5 \\
0 \\
1.0\end{array}$ & $\begin{array}{l}3 \\
3 \\
2 \\
3 \\
\text { (s same) } \\
\text { (s same) } \\
2 \\
2 \\
1 \\
1 \\
\text { (not used) } \\
5 \\
\text { (s same) } \\
1.0 \mathrm{E}-3 \\
1.0 \mathrm{E}-3 \\
2.5 \\
2.0 \mathrm{E}-6 \\
2.0 \mathrm{E}-6 \\
8.3 \mathrm{E}-6 \\
30 .\end{array}$ \\
\hline
\end{tabular}

Release factors are given for each pathway which are to be applied to the basic inventory activites in generation of the release activities.

The waterborne pathway parameters FLOW and PFLOW are calculated for an average annual river flow rate of $1.2 \times 10^{5} \mathrm{ft}^{3} / \mathrm{sec}$ and a population of $3 \times 10^{5}$ people.

A iisting for the sample problem output is given in Figure E.1-2. 


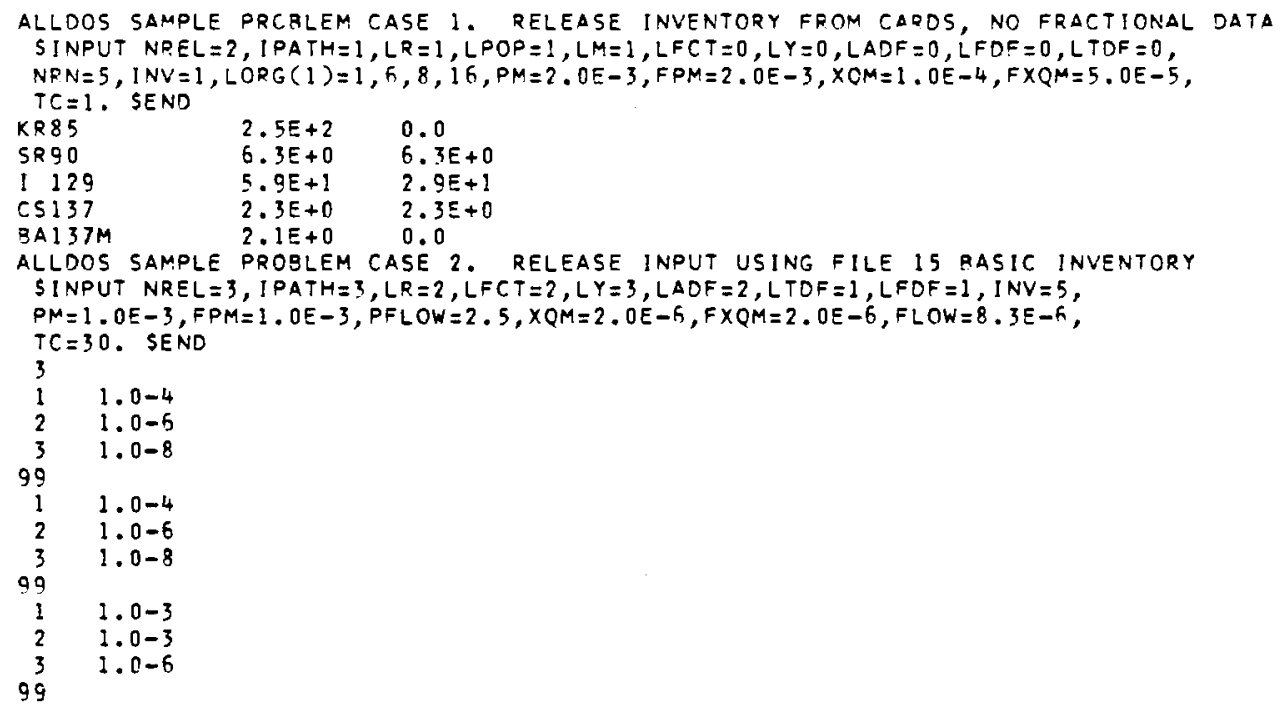

FIGURE E.1-1. SAMPLE Problem Input Card Listing 


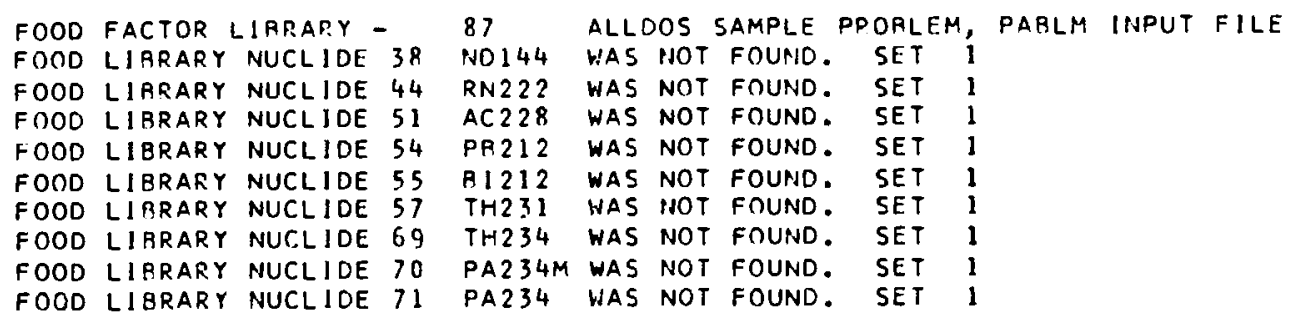

FIGURE E.1-2. ALLDOS Sample Problem Output

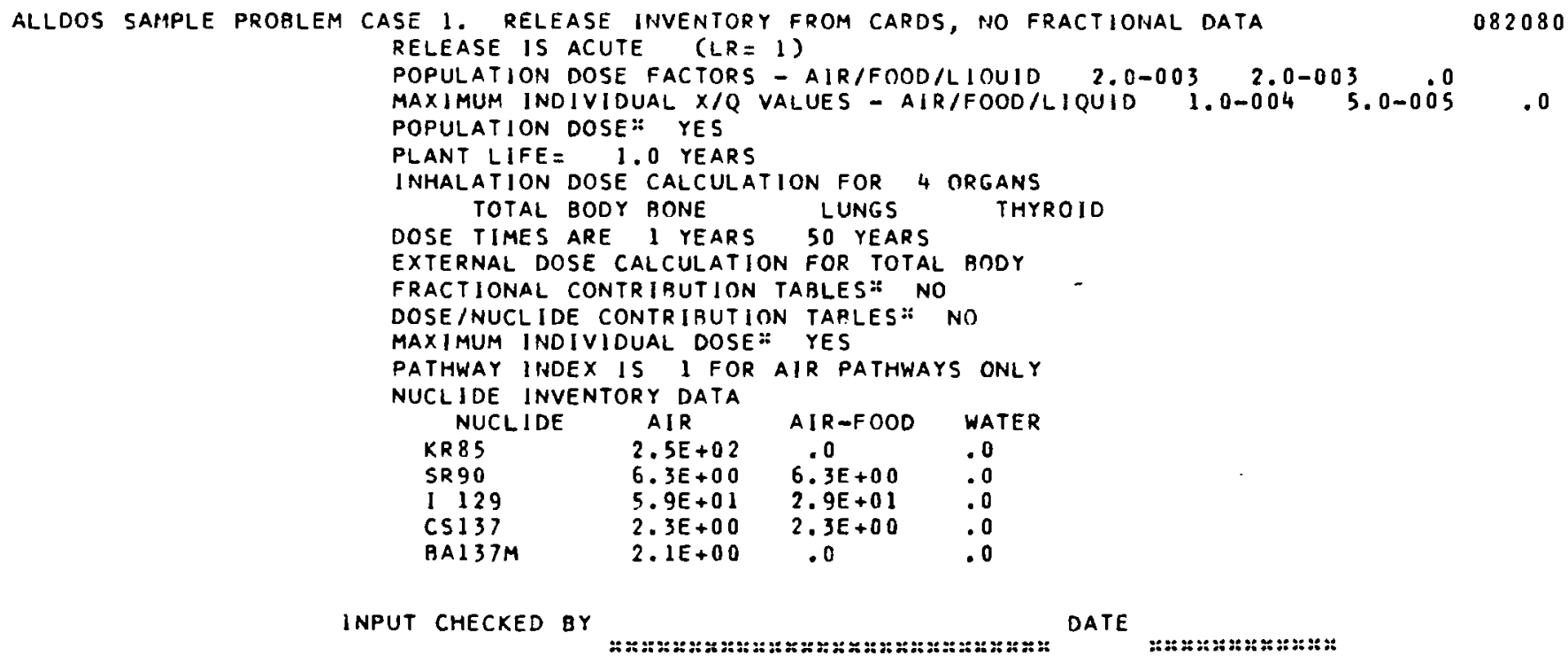

FIGURE E.1-2. ALLDOS Sample Problem Output 
ALLDOS SAMPLE PROBLEM CASE 1. RELEASE INVENTORY FROM CARDS, NO FRACTIONAL DATA

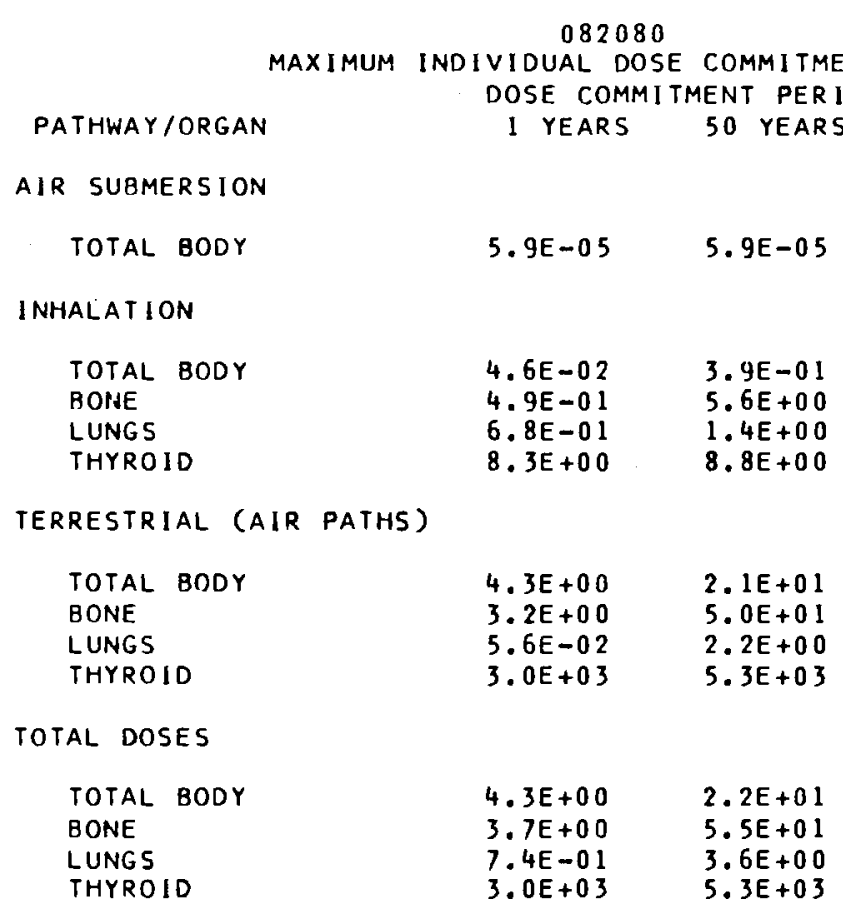

FIGURE E.1-2. ALLDOS Sample Probiem Output

ALldos SAMfle PROBLEM CASE 1. RELEASE INVENTORY FROM CARDS, NO FRACTIONAL DATA

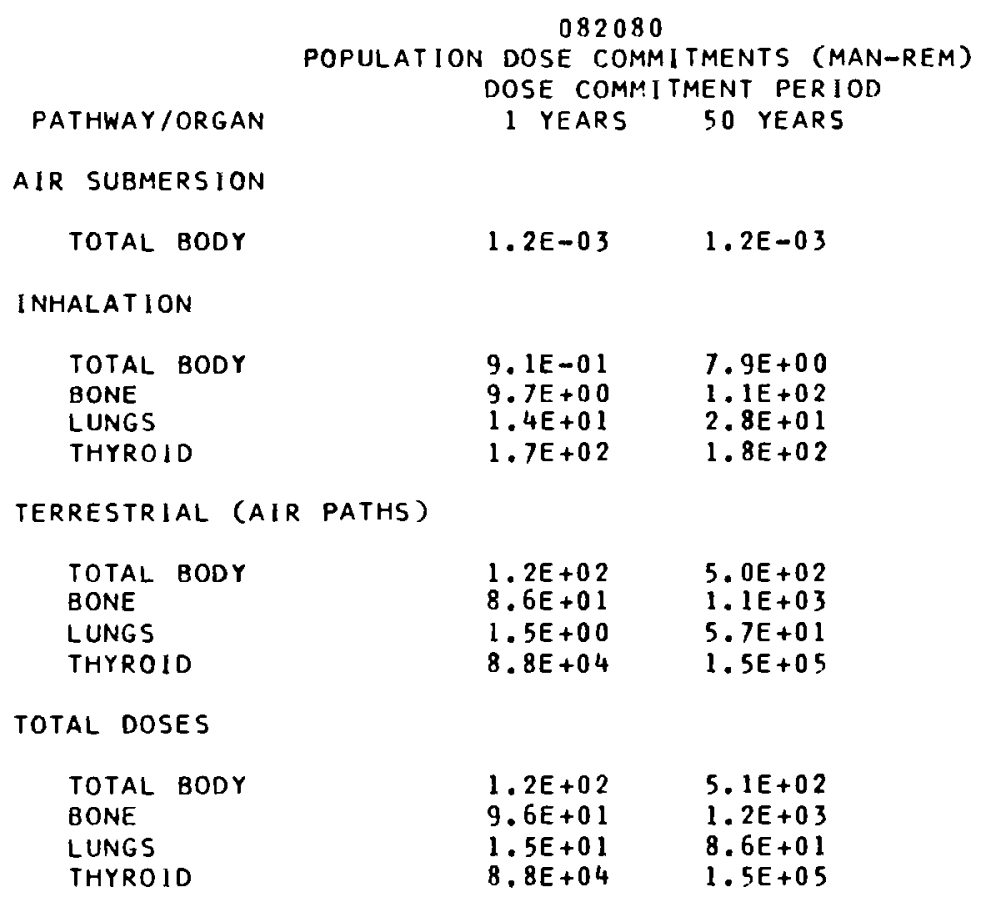

FIGURE E. 1-2. ALLDOS Sample Problem Output 
ALLDOS SAMPLE PRORLEM CASE 2. RELEASE INPUT USING FILE 15 RASIC INVFNTORY

082080 CURIES IN

\begin{tabular}{|c|c|}
\hline NUCL I DE & INVENTORY \\
\hline 113 & $1.4+004$ \\
\hline $\begin{array}{l}C 14 \\
\cos 60\end{array}$ & $\begin{array}{l}1.7+003 \\
3.7+004\end{array}$ \\
\hline N159 & $2.5+003$ \\
\hline $\begin{array}{l}\text { N1 } 63 \\
\text { SE } 79\end{array}$ & $\begin{array}{l}2.7+005 \\
1.0+003\end{array}$ \\
\hline SR90 & $5.7+007$ \\
\hline Y 90 & $5.7+007$ \\
\hline Y 91 & $5.5-003$ \\
\hline 2R93 & $8.5+003$ \\
\hline NA93M & $1.9+003$ \\
\hline ZR 95 & $6.3-002$ \\
\hline NB95M & $1.3-003$ \\
\hline NB 95 & $1.4-001$ \\
\hline TC 99 & $3.8+004$ \\
\hline RU106 & $4.4+005$ \\
\hline $\begin{array}{ll}\text { RHI } 106 \\
\text { PDIO }\end{array}$ & $4.4+005$ \\
\hline $\begin{array}{l}\text { PD } 107 \\
\text { AG I I OM }\end{array}$ & $\begin{array}{l}7.9+001 \\
4.5+002\end{array}$ \\
\hline$A G 110$ & $5.9+001$ \\
\hline SN123 & $4.3+000$ \\
\hline SB125 & $2.1+005$ \\
\hline TE $125 \mathrm{M}$ & $8.8+004$ \\
\hline SN1 26 & $8.7+001$ \\
\hline SB126M & $8.7+001$ \\
\hline $\begin{array}{l}S B 126 \\
T E 127 M\end{array}$ & $\begin{array}{l}8.6+001 \\
1.8+000\end{array}$ \\
\hline TE 127 & $1.8+000$ \\
\hline $\begin{array}{l}1 \quad 129 \\
\operatorname{cs} 134\end{array}$ & $\begin{array}{l}5.9+001 \\
8.3+002\end{array}$ \\
\hline $\operatorname{cs} 135$ & $2.0+002$ \\
\hline CSI37 & $2.1+007$ \\
\hline BA $137 M$ & $1.9+007$ \\
\hline CE 144 & $7.7+005$ \\
\hline PR 144 & $7.7+005$ \\
\hline PMI 47 & $9.9+006$ \\
\hline SM151 & $.5+006$ \\
\hline
\end{tabular}

DF AIR - PLUME $1.0-004$ $1.0-004$ 1. $0-006$ $1.0-006$ 1.0-006 $1.0-006$ 1.0-006 1.0-006 1. $0-006$

$1.0-006$

$1.0-006$ 1. $0-006$ 1. $0-006$ 1.0-006 1. $0-006$ $1.0-006$ 1.0-006 1.0-006 1.0-006 1. 0-006 1.0-006 1.0-006 1. $0-006$ 1. $0-006$ 1. 0006 $1.0-006$ 1. $0-006$ 1. 0-006 1. $0-006$ 1.0-006 1. $0-004$ 1. $0-006$ 1.0-006 1. $0-006$ 1. $0-006$ 1. $0-006$ 1. $0-006$ $1.0-006$
$1.0-006$ DF AIR-FOOD 1. $0-004$ 1. $0-004$ 1.0-006 1. $0-006$ $1.0-006$
$1.0-006$ $1.0-006$
$1.0-006$ 1. $0-006$ 1. $0-006$ 1. $0-006$ 1. $0-006$ 1. $0-006$ $1.0-006$ 1. $0-006$ 1. $0-006$ 1. $0-006$ $1.0-006$ 1. $0-006$ 1. $0-006$ 1. $0-006$ $1.0-006$ $1.0-006$ 1. $0-006$ $1.0-006$ 1. 00006 $1.0-006$
$1.0-006$ $1.0-006$
$1.0-006$ $1.0-004$ 1. $0-006$ 1. $0-006$ 1.00006 1. $0-006$ 1.0-006 1. 0-006 1.0-006 1. 0-006 SOURCE IERM CALCULAIION SUMMARY

\begin{tabular}{|c|c|c|c|c|c|}
\hline $\begin{array}{c}\text { DF } \\
\text { LIQUID }\end{array}$ & $\begin{array}{c}\text { CURIES } \\
\text { AIR-PLUME }\end{array}$ & $\begin{array}{r}\text { CURIES } \\
\text { AIR FOOD }\end{array}$ & $\begin{array}{l}\text { CURIES } \\
\text { LIQUID }\end{array}$ & $\begin{array}{c}\text { FRACTIONATION } \\
\text { CLASS }\end{array}$ & NUCL IDE \\
\hline $1.0-003$ & $1.4+000$ & $1.4+000$ & $1.4+001$ & $\mathrm{H} 3, \mathrm{C} 14, \mathrm{I}$ & H 3 \\
\hline $\begin{array}{l}1.0-003 \\
1.0-003\end{array}$ & $\begin{array}{l}1.7-001 \\
3.7-002\end{array}$ & $\begin{array}{l}1.7-001 \\
3.7-002\end{array}$ & $\begin{array}{l}1.7+000 \\
3.7+001\end{array}$ & $\begin{array}{l}\mathrm{H3}, \mathrm{C} 14, \mathrm{I} \\
F P+A P\end{array}$ & $\begin{array}{l}C 14 \\
\cos 10\end{array}$ \\
\hline $1.0-003$ & $2.5-003$ & $2.5-003$ & $2.5+000$ & $F P+A P$ & N159 \\
\hline $\begin{array}{l}1.0-003 \\
1.0-0003\end{array}$ & $\begin{array}{l}2.7-001 \\
1.0-003\end{array}$ & $\begin{array}{l}2.7-001 \\
1.0-003\end{array}$ & $\begin{array}{l}2.7+002 \\
1.0+000\end{array}$ & $\begin{array}{l}F P+A P \\
F P+A P\end{array}$ & $\begin{array}{l}\text { N163 } \\
\text { SE } 79\end{array}$ \\
\hline $1.0-003$ & $5.7+001$ & $5.7+001$ & $5.7+004$ & $F P+A P$ & SR9O \\
\hline $\begin{array}{l}1.0-003 \\
1.0-003 \\
0-003\end{array}$ & $\begin{array}{l}5.7+001 \\
5.5-009 \\
8.5-003\end{array}$ & $\begin{array}{l}5.7+001 \\
5.5-000 \\
8.5-003\end{array}$ & $\begin{array}{l}5.7+004 \\
5.5-006 \\
8.5+000\end{array}$ & $\begin{array}{l}F P+A P \\
F P+A P \\
F P+A P\end{array}$ & $\begin{array}{ll}Y & 90 \\
Y & 91 \\
Z R & 93\end{array}$ \\
\hline $\begin{array}{l}1.0-003 \\
1.0-003 \\
1.0-003\end{array}$ & $\begin{array}{l}8.5-003 \\
1.9-003 \\
6.3-008\end{array}$ & $\begin{array}{l}8.5-003 \\
1.9-003 \\
6.3-008\end{array}$ & $\begin{array}{l}8.5+000 \\
1.9+000 \\
6.3-005\end{array}$ & $\begin{array}{l}F P+A P \\
F P+A P\end{array}$ & $\begin{array}{l}\text { NR93 } \\
\text { ZR95 } \\
\text { ZR95 }\end{array}$ \\
\hline $1.0-003$ & $1.3-009$ & $1.3-009$ & $1.3-006$ & $F P+A P$ & N895M \\
\hline $\begin{array}{l}1.0-003 \\
1.00003\end{array}$ & $\begin{array}{l}1.4-007 \\
3.8-002\end{array}$ & $\begin{array}{l}1.4-007 \\
3.8-002\end{array}$ & $\begin{array}{l}1.4-004 \\
3.8+001\end{array}$ & $\begin{array}{l}F P+A P \\
F P+A P\end{array}$ & $\begin{array}{l}\text { NB95 } \\
\text { TC99 }\end{array}$ \\
\hline $1.0-003$ & $4.4-001$ & $4.4-001$ & $4.4+002$ & $F P+A P$ & RU106 \\
\hline $\begin{array}{l}1.0-003 \\
1.0-003\end{array}$ & $\begin{array}{l}4.4-001 \\
7.9-005\end{array}$ & $\begin{array}{l}4.4-001 \\
7.9-005\end{array}$ & $\begin{array}{l}4.4+002 \\
7.9-002\end{array}$ & $\begin{array}{l}F P+A P \\
F P+A P \\
F P+A P\end{array}$ & 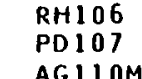 \\
\hline $1.0-003$ & $4.5-004$ & $4.5-0$ & $4.5-001$ & $F P+A P$ & AG $110 M$ \\
\hline $\begin{array}{l}1.0-003 \\
1.0-003\end{array}$ & $\begin{array}{l}5.9-005 \\
4.3-006\end{array}$ & $\begin{array}{l}5.9-005 \\
4.3-006\end{array}$ & $\begin{array}{l}5.9-002 \\
4.3-003\end{array}$ & $\begin{array}{l}F P+A P \\
F P+A P\end{array}$ & $\begin{array}{l}\text { AG } 1110 \\
\text { SN } 123\end{array}$ \\
\hline $1.0-003$ & $2.1-001$ & $2.1-001$ & $2.1+002$ & $F P+A P$ & SA125 \\
\hline $\begin{array}{l}1.0-003 \\
1.0-003\end{array}$ & $\begin{array}{l}8.7-002 \\
8.7-005\end{array}$ & $\begin{array}{l}8.7-002 \\
8.7-005\end{array}$ & $\begin{array}{l}8.8+001 \\
8.7-002\end{array}$ & $\begin{array}{l}F P+A P \\
F P+A P\end{array}$ & $\begin{array}{l}\text { TE } 125 M \\
\text { SN126 }\end{array}$ \\
\hline $1.0-003$ & $8.7-005$ & $8.7-005$ & $8.7-002$ & $F P+A P$ & $S B 126 M$ \\
\hline $1.0-003$ & 8. $6-005$ & 8.6-005 & $8.6-002$ & $F P+A P$ & $\begin{array}{l}\text { SHI26 } \\
\text { TFI }\end{array}$ \\
\hline 0 & & $1.8-006$ & $1.9-003$ & $F P+A P$ & TE $127 \mathrm{M}$ \\
\hline $1.0-003$ & $1.8-006$ & $1.8-006$ & $1.8-003$ & $F P+A P$ & TE 127 \\
\hline $\begin{array}{l}1.0-003 \\
1.0-0.03\end{array}$ & $\begin{array}{l}5.9-003 \\
8.3-004\end{array}$ & $\begin{array}{l}5.9-003 \\
8.3-004\end{array}$ & $\begin{array}{l}5.9-002 \\
8.3-001\end{array}$ & $\begin{array}{l}\mathrm{H3}, \mathrm{C} 14, \mathrm{I} \\
F P+A P\end{array}$ & $\begin{array}{l}1 \quad 129 \\
\operatorname{cs} 134\end{array}$ \\
\hline $1.0-003$ & $2.0-004$ & $2.0-004$ & $2.0-001$ & $F P+A P$ & CS135 \\
\hline $\begin{array}{l}1.0-0 \\
0-0\end{array}$ & $2.1+001$ & $\begin{array}{r}2.1+001 \\
9+001\end{array}$ & $\begin{array}{l}2.1+004 \\
9+004\end{array}$ & $\begin{array}{l}F P+A P \\
F P+A P\end{array}$ & $\begin{array}{l}\text { C5137 } \\
\text { BAI37M }\end{array}$ \\
\hline $1.0-003$ & $7.7-001$ & $7.7-001$ & $7.7+002$ & $F P+A P$ & $C E 144$ \\
\hline $1.0-003$ & $7.7-001$ & $7.7-001$ & $7.7+002$ & $F P+A P$ & PR144 \\
\hline .0 .003 & $9.9+000$ & $9.9+000$ & 003 & $F P+A P$ & PM147 \\
\hline-003 & $.5+000$ & $1.5+000$ & +003 & $F P+A P$ & SMI51 \\
\hline
\end{tabular}

FIGURE E.1-2. ALLDOS Sample Problem Output 


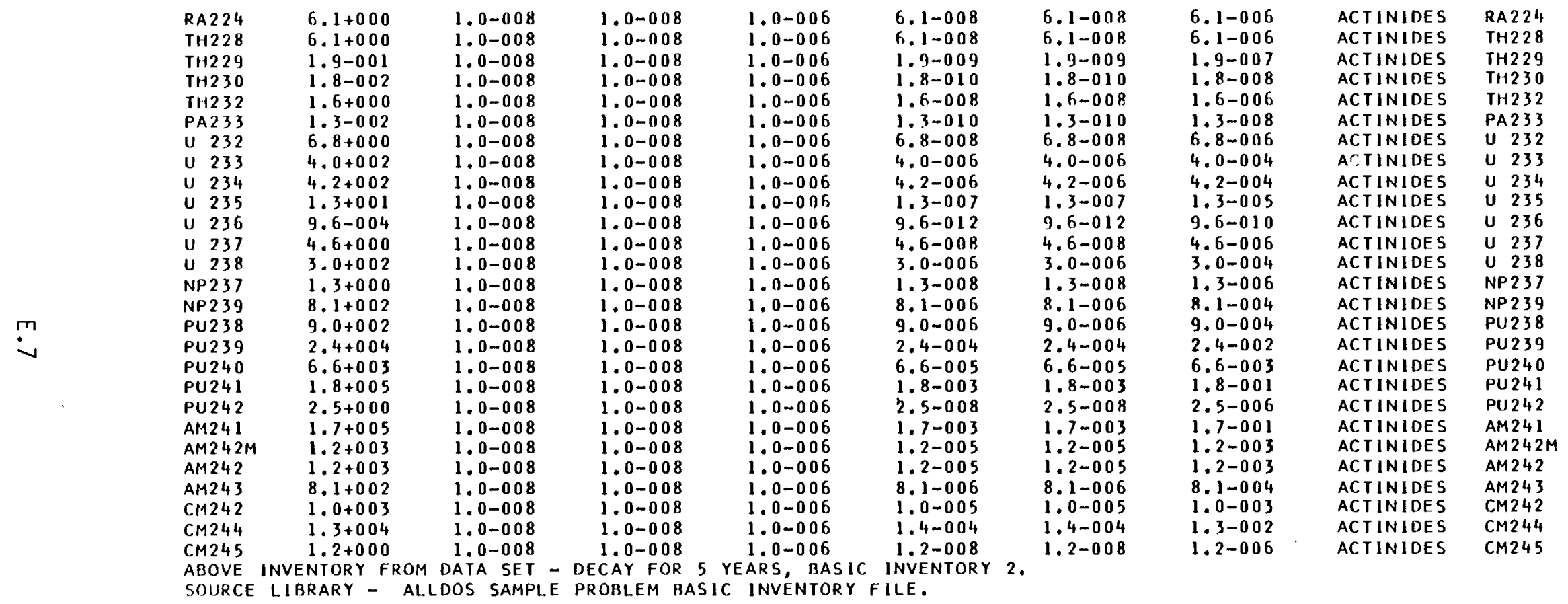

FIGURE E.1-2. ALLDOS Sample Problem Output 
ALLDOS SAMPLE PRORLEM OUTPUT

ALLDOS SAMPLE PRORLEM CASE 2. RELEASE INPUT USING FILE 15 RASIC INVENTORY O82080 RELEASE IS CHRONIC (LR= 2)

POPULATION DOSE FACTORS - AIR/FOOD/LIOUID $1.0-003 \quad 1.0-003 \quad 2.5+000$ MAXIMUM INDIVIDUAL X/Q VALUES - AIR/FOOD/LIQUID 2.0-006 2.0-006 8.3-006 POPULATION DOSE: YES

PLANT LIFE = 30.0 YEARS TOTAL BODY PONE

LUNGS

DOSE TIMES ARE 1 YEARS 70 YEARS
EXIERNAL DOSE CALCULATION FOR TOTAL BODY

FRACTIONAL CONTRIAUTION TARLES: NO

DOSE/NUCLIDE CONTRIBUTION TABLES: YES

MAXIMUM INDIVIDUAL DOSE: YES

PATHWAY INDEX IS. 3 FOR AIR AND LIQUID PATHS NUCLIDE INVENTORY DATA

$\begin{array}{llll}\text { NUCLIDE } & \text { AIR } & \text { AIR-FOOD } & \text { WATER } \\ \text { H } 3 & 1.4 E+00 & 1.4 E+00 & 1.4 E+01 \\ \text { C 14 } & 1.7 E-01 & 1.7 E-01 & 1.7 E+00 \\ \text { CO60 } & 3.7 E-02 & 3.7 E-02 & 3.7 E+01 \\ \text { N159 } & 2.5 E-03 & 2.5 E-03 & 2.5 E+00 \\ \text { NI63 } & 2.7 E-01 & 2.7 E-01 & 2.7 E+02 \\ \text { SE 79 } & 1.0 E-03 & 1.0 E-03 & 1.0 E+00 \\ \text { SR90 } & 5.7 E+01 & 5.7 E+01 & 5.7 E+04 \\ \text { Y 90 } & 5.7 E+01 & 5.7 E+01 & 5.7 E+04 \\ \text { Y 91 } & 5.5 E-09 & 5.5 E-09 & 5.5 E-06 \\ \text { ZR93 } & 8.5 E-03 & 8.5 E-03 & 8.5 E+00 \\ \text { NB93M } & 1.9 E-03 & 1.9 E-03 & 1.9 E+00 \\ \text { ZR95 } & 6.3 E-08 & 6.3 E-08 & 6.3 E-05 \\ \text { NB95M } & 1.3 E-09 & 1.3 E-09 & 1.3 E-06 \\ \text { NA95 } & 1.4 E-07 & 1.4 E-07 & 1.4 E-04 \\ \text { TC99 } & 3.8 E-02 & 3.8 E-02 & 3.8 E+01 \\ \text { RH106 } & 4.4 E-01 & 4.4 E-01 & 4.4 E+02 \\ \text { RU106 } & 4.4 E-01 & 4.4 E-01 & 4.4 E+02 \\ \text { PD107 } & 7.9 E-05 & 7.9 E-05 & 7.9 E-02 \\ \text { AG110 } & 5.9 E-05 & 5.9 E-05 & 5.9 E-02 \\ \text { AG110M } & 4.5 E-04 & 4.5 E-04 & 4.5 E-01 \\ \text { SN123 } & 4.3 E-06 & 4.3 E-06 & 4.3 E-03 \\ \text { SB125 } & 2.1 E-01 & 2.1 E-01 & 2.1 E+02 \\ \text { TE125M } & 8.7 E-02 & 8.7 E-02 & 8.8 E+01 \\ \text { SN126 } & 8.7 E-05 & 8.7 E-05 & 8.7 E-02 \\ \text { SB126M } & 8.7 E-05 & 8.7 E-05 & 8.7 E-02 \\ \text { SB126 } & 8.6 E-05 & 8.6 E-05 & 8.6 E-02 \\ \text { TE127M } & 1.8 E-06 & 1.8 E-06 & 1.9 E-03 \\ \text { IE127 } & 1.8 E-06 & 1.8 E-06 & 1.8 E-03 \\ 11129 & 5.9 E-03 & 5.9 E-03 & 5.9 E-02 \\ \text { CS134 } & 8.3 E-04 & 8.3 E-04 & 8.3 E-01 \\ \text { CS135 } & 2.0 E-04 & 2.0 E-04 & 2.0 E-01 \\ \text { CS137 } & 2.1 E+01 & 2.1 E+01 & 2.1 E+04\end{array}$

FIGURE E.1-2. ALLDOS Sample Problem Output 


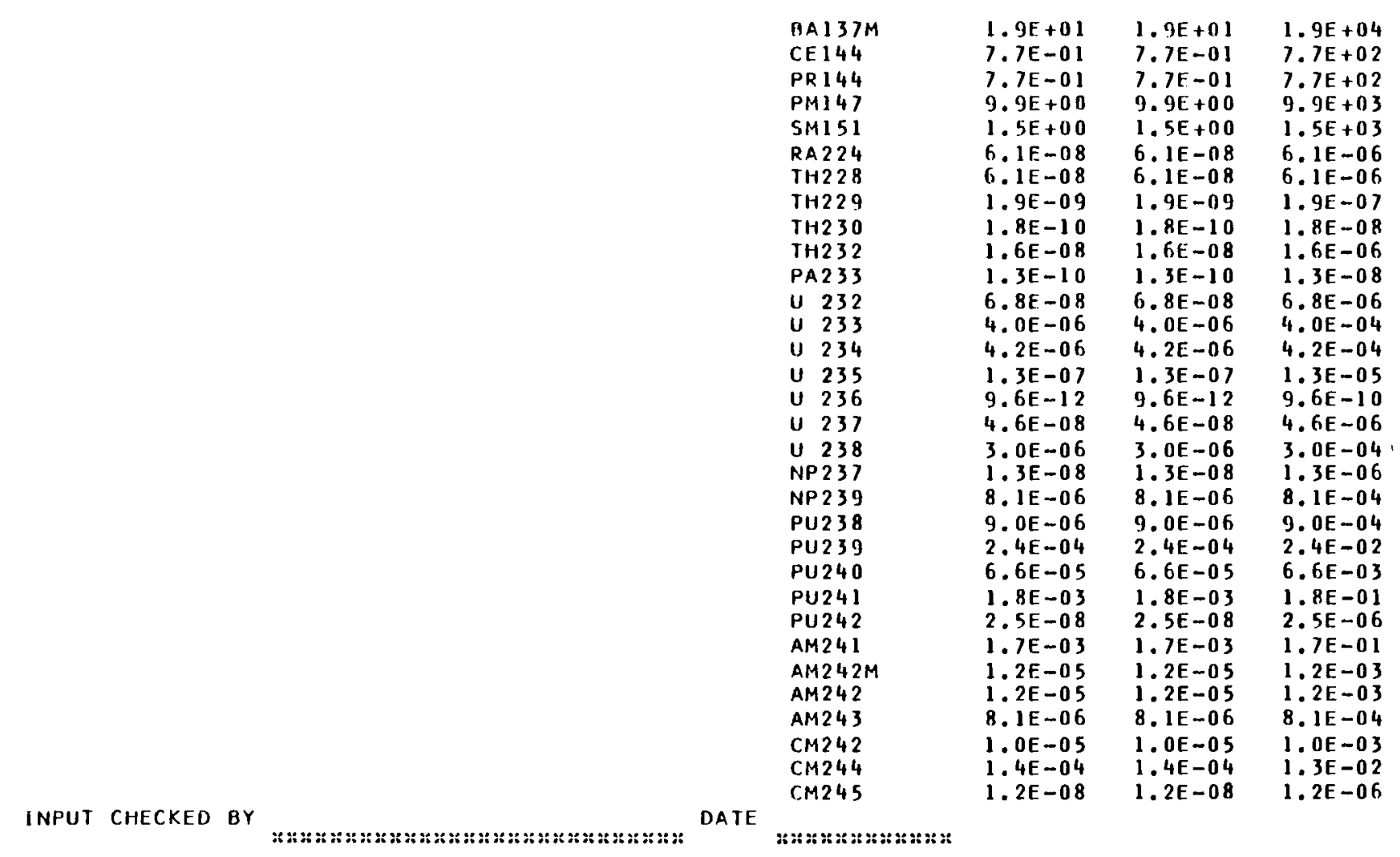

FIGURE E.1-2. ALLDOS Sample Problem Output 


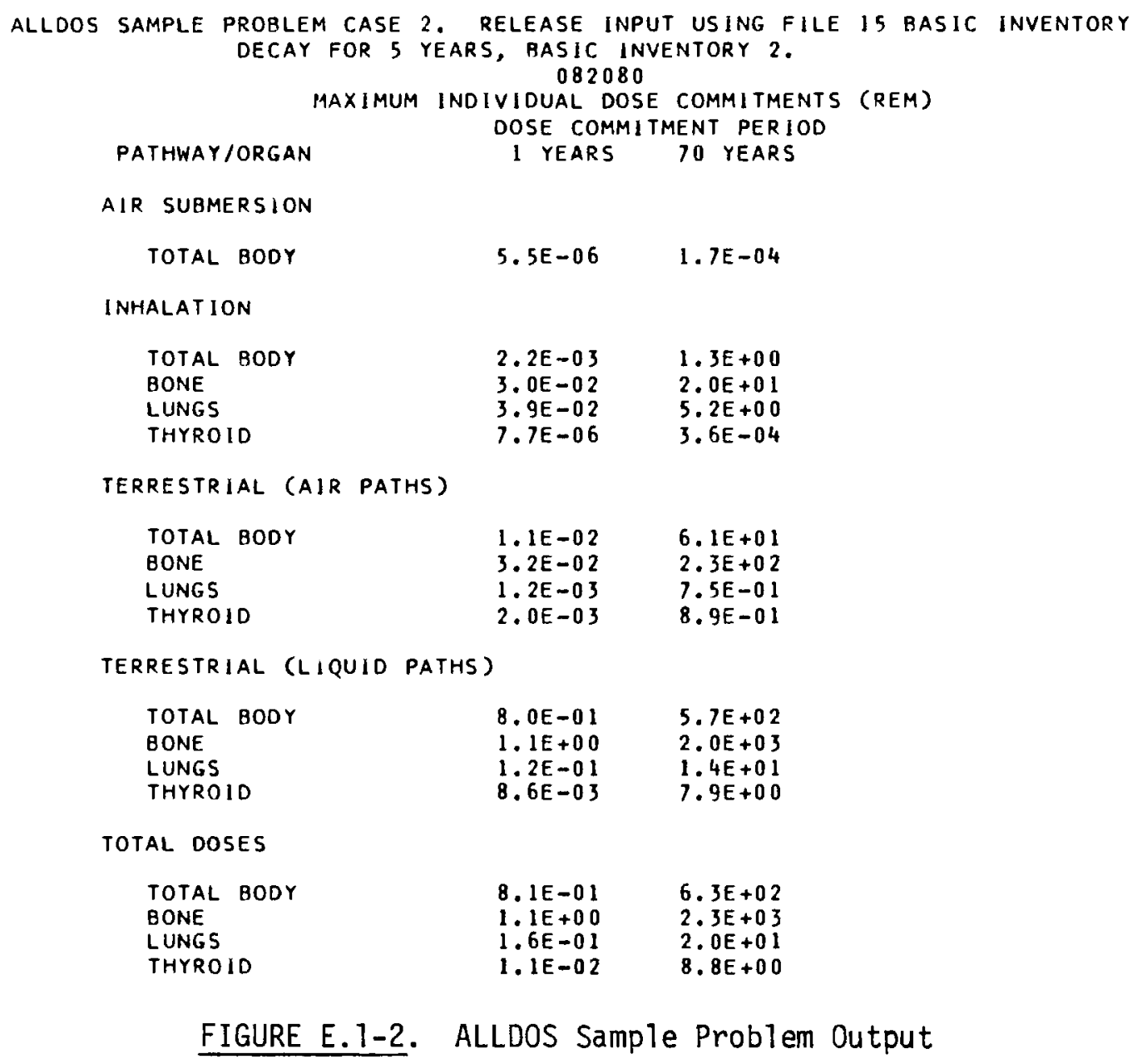




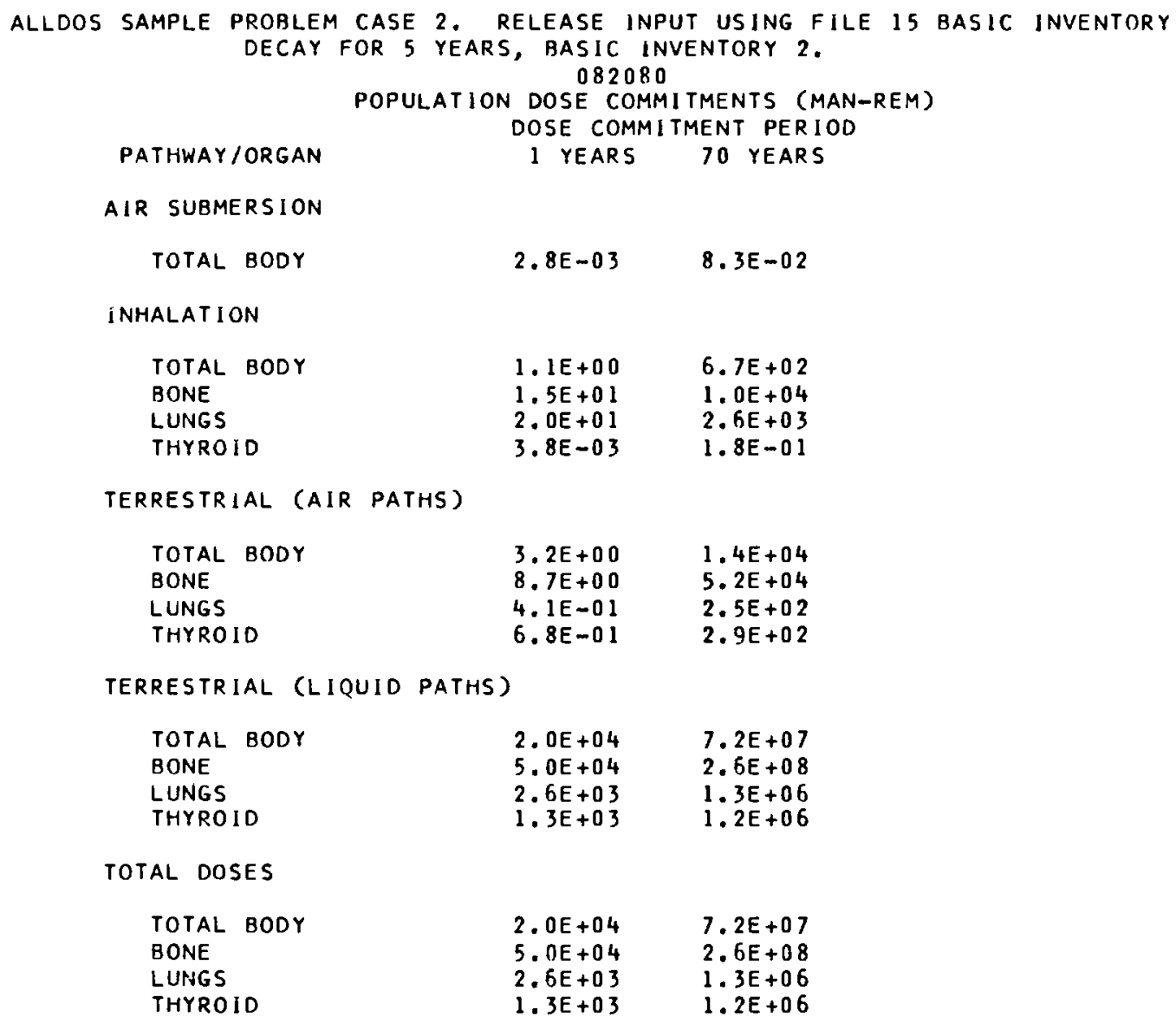

FIGURE E. 1-2. ALLDOS Sample Problem Output 
ALLDOS SAMPLE PROBLEM CASE 2. RELEASE INPUT USING FILE 15 BASIC INVENTORY DECAY FOR 5 YEARS, BASIC INVENTORY 2. 082080

DOSE BY NUCLIDE FOR THE MAXIMUM INDIVIDUAL. DOSE TIME 1 YEARS

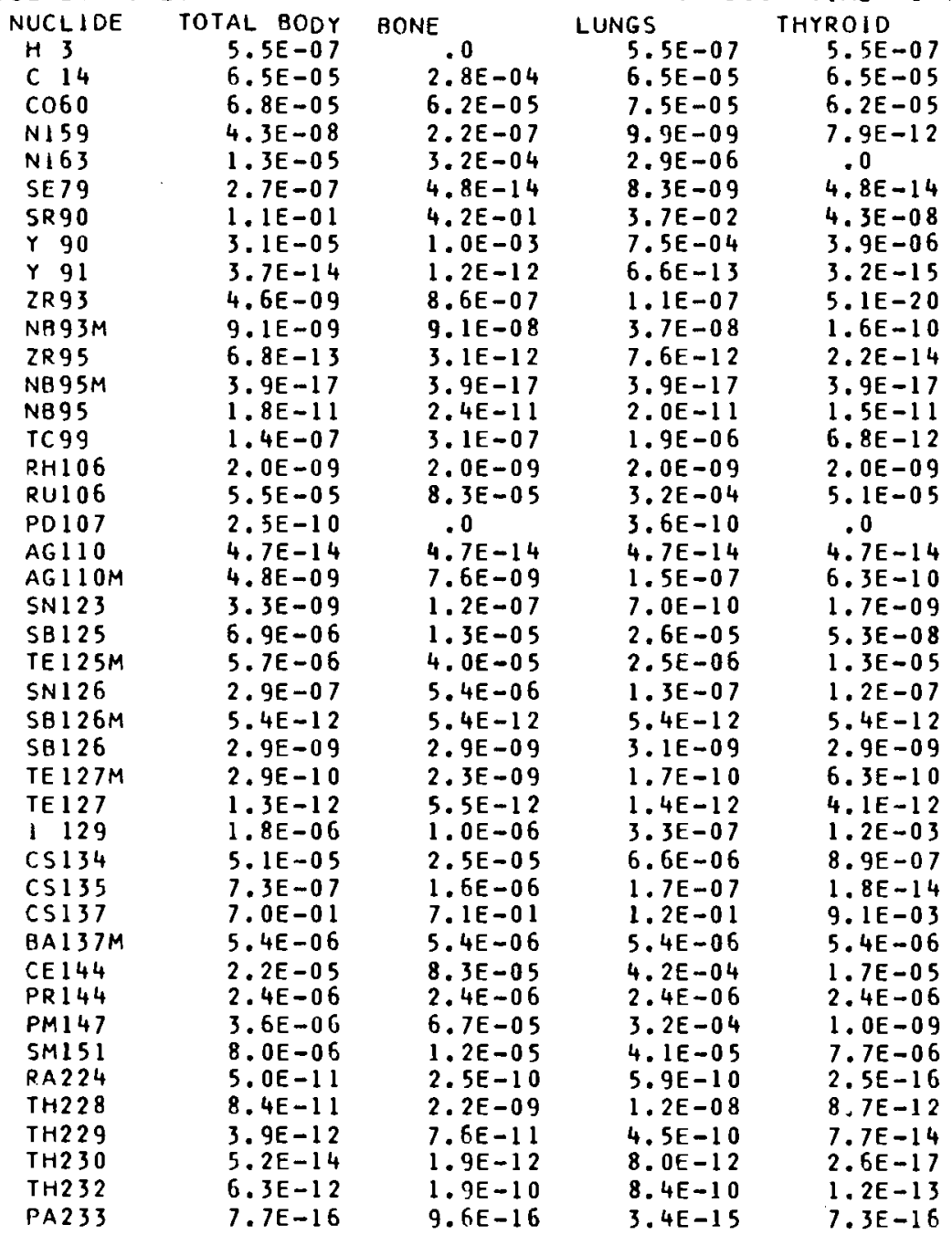

FIGURE E.1-2. ALLDOS Sample Problem Output 


$\begin{array}{lllll}U 232 & 1.1 E-10 & 7.7 E-10 & 1.2 E-08 & 3.2 E-15 \\ U 233 & 1.1 E-09 & 9.5 E-09 & 1.8 E-07 & 4.2 E-13 \\ U 234 & 1.2 E-09 & 9.7 E-09 & 1.8 E-07 & 5.7 E-13 \\ U 235 & 3.4 E-11 & 2.8 E-10 & 5.3 E-09 & 4.0 E-13 \\ U 236 & 2.6 E-15 & 2.1 E-14 & 4.0 E-13 & 3.7 E-20 \\ U 237 & 1.6 E-15 & 1.6 E-15 & 1.6 E-15 & 1.6 E-15 \\ U 238 & 7.5 E-10 & 6.4 E-09 & 1.2 E-07 & 2.5 E-12 \\ \text { NP237 } & 4.4 E-12 & 9.2 E-11 & 5.9 E-10 & 3.5 E-13 \\ \text { NP239 } & 2.0 E-11 & 2.3 E-11 & 3.8 E-11 & 2.0 E-11 \\ \text { PU238 } & 3.1 E-09 & 6.9 E-08 & 4.7 E-07 & 2.2 E-13 \\ \text { PU239 } & 7.7 E-08 & 1.7 E-06 & 1.2 E-05 & 3.7 E-12 \\ \text { PU240 } & 2.1 E-08 & 4.8 E-07 & 3.2 E-06 & 1.6 E-12 \\ \text { PU241 } & 2.5 E-08 & 7.0 E-07 & 1.7 E-07 & .0 \\ \text { PU242 } & 7.5 E-12 & 1.7 E-10 & 1.2 E-09 & 5.3 E-16 \\ \text { AM241 } & 5.9 E-07 & 1.3 E-05 & 8.8 E-05 & 5.7 E-09 \\ \text { AM242M } & 4.4 E-09 & 1.0 E-07 & 4.4 E-07 & 5.8 E-12 \\ \text { AM242 } & 1.8 E-11 & 4.1 E-10 & 3.9 E-09 & 1.6 E-14 \\ \text { AM243 } & 2.8 E-09 & 5.9 E-08 & 3.9 E-07 & 1.9 E-10 \\ \text { CM242 } & 3.0 E-09 & 6.6 E-08 & 3.8 E-07 & 5.7 E-13 \\ \text { CM244 } & 4.6 E-08 & 1.1 E-06 & 7.3 E-06 & 7.2 E-12 \\ \text { CM245 } & 4.3 E-12 & 9.2 E-11 & 6.0 E-10 & 2.1 E-13\end{array}$

FIGURE E.1-2. ALLDOS Sample Problem Output 
ALLDOS SAMPLE PROBLEM CASE 2 . RELEASE INPUT USING FILE 15 RASIC INVENTORY DECAY FOR 5 YEARS, BASIC INVENTORY 2. 082080

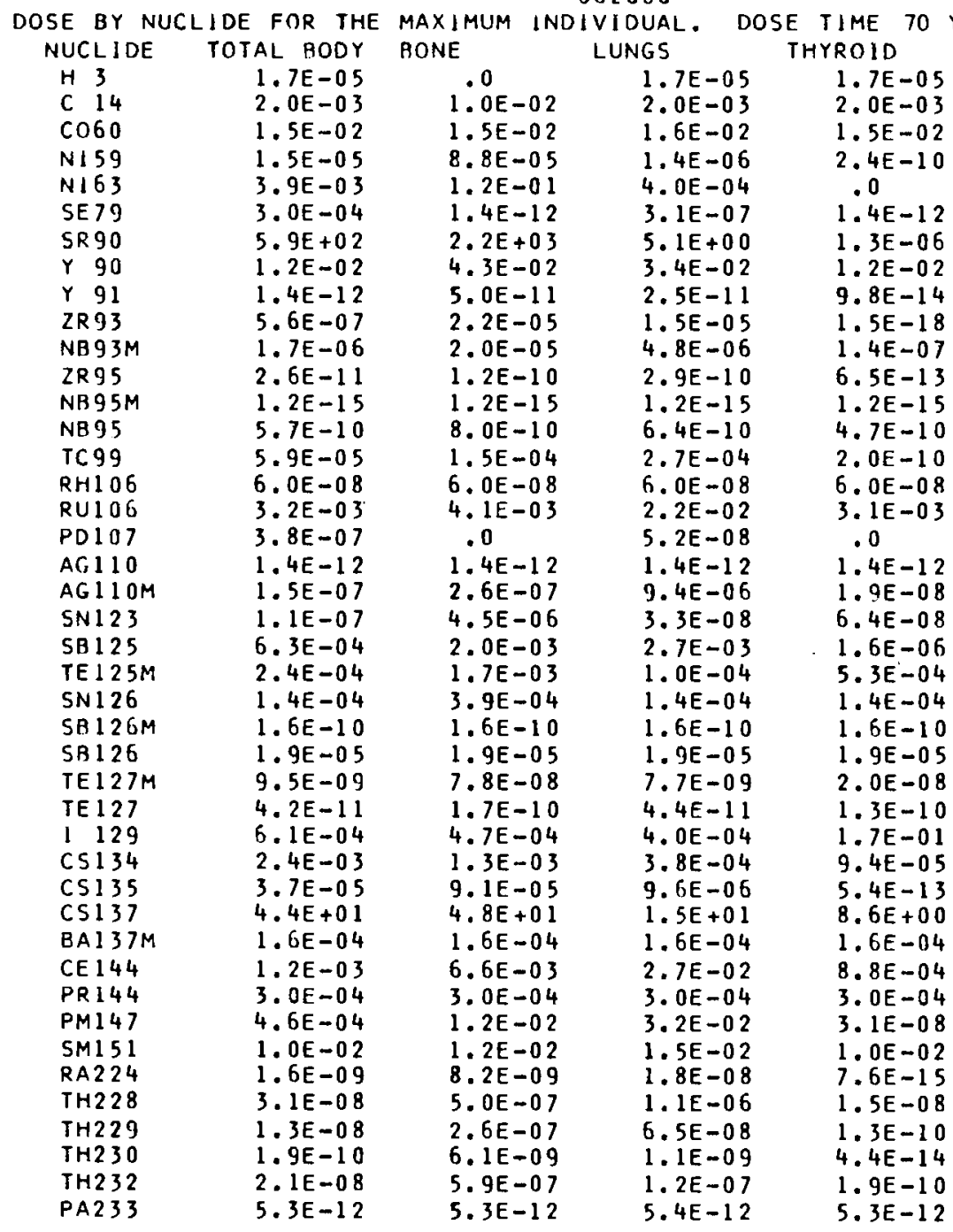

\section{FIGURE E.1-2. ALLDOS Sample Problem Output}




$\begin{array}{lllll}U 232 & 6.2 E-09 & 8.5 E-08 & 1.6 E-06 & 4.2 E-12 \\ U 233 & 6.9 E-08 & 1.1 E-06 & 2.4 E-05 & 7.0 E-10 \\ U 234 & 7.0 E-08 & 1.1 E-06 & 2.5 E-05 & 9.4 E-10 \\ U 235 & 2.3 E-09 & 2.8 E-08 & 7.3 E-07 & 6.4 E-10 \\ U 236 & 1.6 E-13 & 2.5 E-12 & 5.6 E-11 & 6.2 E-17 \\ U 237 & 4.8 E-14 & 4.8 E-14 & 4.8 E-14 & 4.8 E-14 \\ U 238 & 4.3 E-08 & 6.4 E-07 & 1.6 E-05 & 4.2 E-09 \\ N P 237 & 1.4 E-08 & 2.9 E-07 & 8.1 E-08 & 5.8 E-10 \\ N P 239 & 2.3 E-07 & 2.3 E-07 & 2.3 E-07 & 2.3 E-07 \\ \text { PU238 } & 8.7 E-06 & 1.8 E-04 & 6.5 E-05 & 3.4 E-10 \\ \text { PU239 } & 2.7 E-04 & 5.6 E-03 & 1.6 E-03 & 5.8 E-09 \\ \text { PU240 } & 7.2 E-05 & 1.6 E-03 & 4.4 E-04 & 2.6 E-09 \\ \text { PU241 } & 3.2 E-05 & 8.4 E-04 & 2.2 E-05 & .0 \\ \text { PU242 } & 2.7 E-08 & 5.4 E-07 & 1.7 E-07 & 8.5 E-13 \\ \text { AM241 } & 1.6 E-03 & 4.0 E-02 & 1.2 E-02 & 9.4 E-06 \\ \text { AM242M } & 1.1 E-05 & 2.9 E-04 & 6.0 E-05 & 8.5 E-09 \\ \text { AM242 } & 5.4 E-10 & 1.2 E-08 & 1.2 E-07 & 4.9 E-13 \\ \text { AM243 } & 7.7 E-06 & 1.9 E-04 & 5.4 E-05 & 3.2 E-07 \\ \text { CM242 } & 1.9 E-07 & 4.4 E-06 & 2.0 E-05 & 1.2 E-09 \\ \text { CM244 } & 6.4 E-05 & 1.6 E-03 & 9.7 E-04 & 4.9 E-09 \\ \text { CM245 } & 1.2 E-08 & 3.0 E-07 & 8.7 E-08 & 3.5 E-10\end{array}$

FIGURE E.1-2. ALLDOS Sample Problem Output 


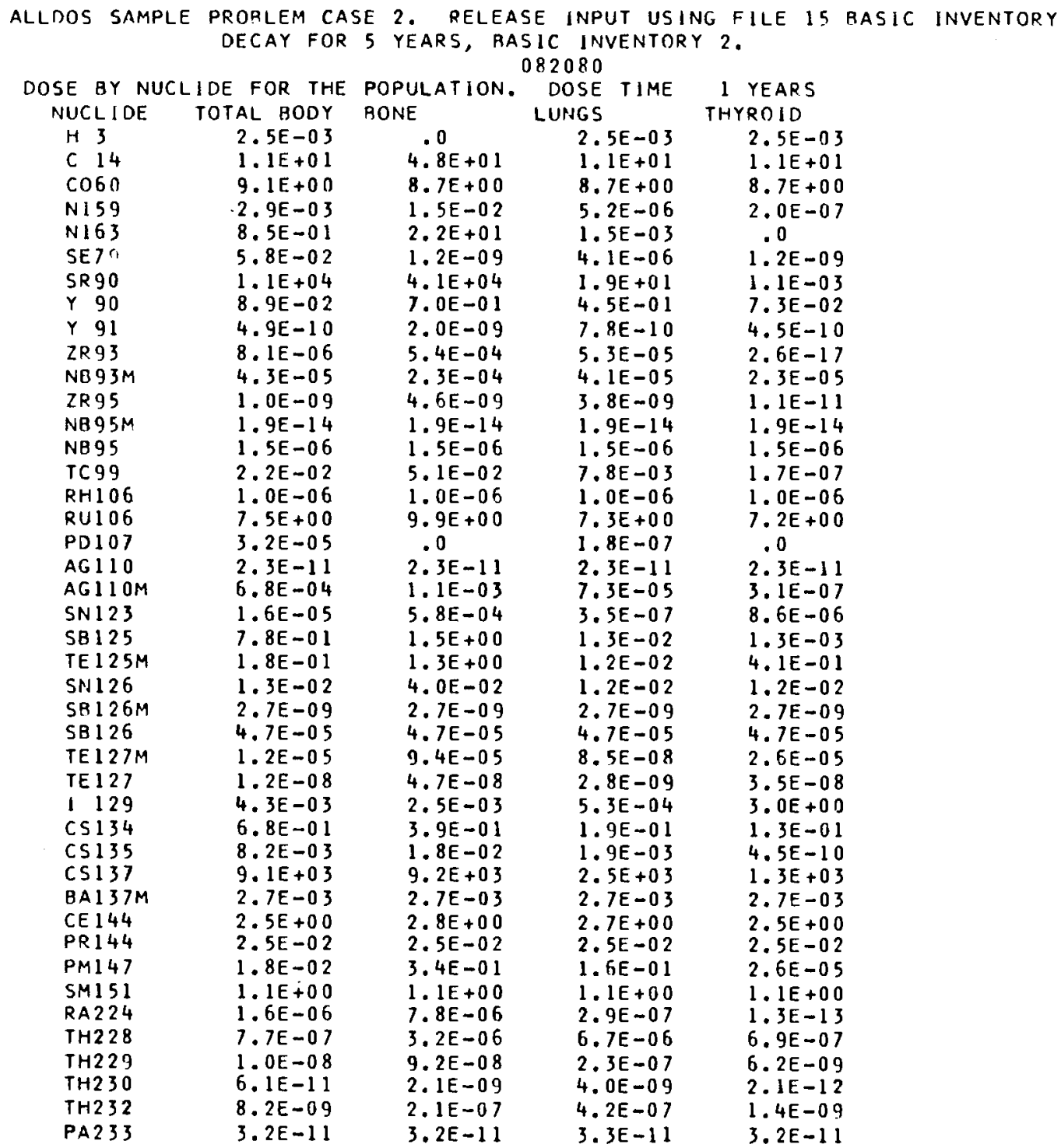

FIGURE E.1-2. ALLDOS Sample Problem Output 


$\begin{array}{lllll}U 232 & 4.1 E-06 & 2.9 E-05 & 5.8 E-06 & 2.6 E-10 \\ U 233 & 4.3 E-05 & 3.6 E-04 & 9.1 E-05 & 3.4 E-08 \\ U 234 & 4.4 E-05 & 3.6 E-04 & 9.2 E-05 & 4.6 E-08 \\ U 235 & 1.2 E-06 & 1.0 E-05 & 2.7 E-06 & 4.1 E-09 \\ U 236 & 9.7 E-11 & 8.0 E-10 & 2.0 E-10 & 3.0 E-15 \\ U 237 & 8.0 E-13 & 8.0 E-13 & 8.0 E-13 & 8.0 E-13 \\ U 238 & 2.8 E-05 & 2.4 E-04 & 6.1 E-05 & 2.6 E-08 \\ \text { NP237 } & 3.3 E-08 & 1.3 E-07 & 3.2 E-07 & 2.8 E-08 \\ \text { NP239 } & 3.0 E-07 & 3.0 E-07 & 3.1 E-07 & 3.0 E-07 \\ \text { PU238 } & 2.1 E-06 & 4.7 E-05 & 2.3 E-04 & 1.7 E-08 \\ \text { PU239 } & 5.3 E-05 & 1.2 E-03 & 5.8 E-03 & 2.8 E-07 \\ \text { PU240 } & 1.5 E-05 & 3.3 E-04 & 1.6 E-03 & 1.3 E-07 \\ \text { PU241 } & 1.7 E-05 & 4.8 E-04 & 8.5 E-05 & .07 \\ \text { PU242 } & 5.2 E-09 & 1.2 E-07 & 5.8 E-07 & 4.1 E-11 \\ \text { AM241 } & 1.1 E-03 & 1.5 E-02 & 4.5 E-02 & 4.6 E-04 \\ \text { AM242M } & 5.4 E-05 & 1.1 E-04 & 2.2 E-04 & 4.7 E-07 \\ \text { AM242 } & 1.1 E-08 & 2.5 E-07 & 1.9 E-06 & 8.2 E-12 \\ \text { AM243 } & 1.9 E-05 & 8.2 E-05 & 2.1 E-04 & 1.6 E-05 \\ \text { CM242 } & 3.3 E-06 & 7.2 E-05 & 1.9 E-04 & 4.2 E-08 \\ \text { CM244 } & 5.3 E-05 & 1.2 E-03 & 3.6 E-03 & 5.7 E-07 \\ \text { CM245 } & 2.2 E-08 & 1.2 E-07 & 3.2 E-07 & 1.7 E-08\end{array}$

FIGURE E.1-2. ALLDOS Sample Problem Output 
ALLDOS SAMPLE PROBLEM CASE 2. RELEASE INPUT USING FILE 15 BASIC INVENTORY DECAY FOR 5 YEARS, AASIC INVENTORY 2. 082080

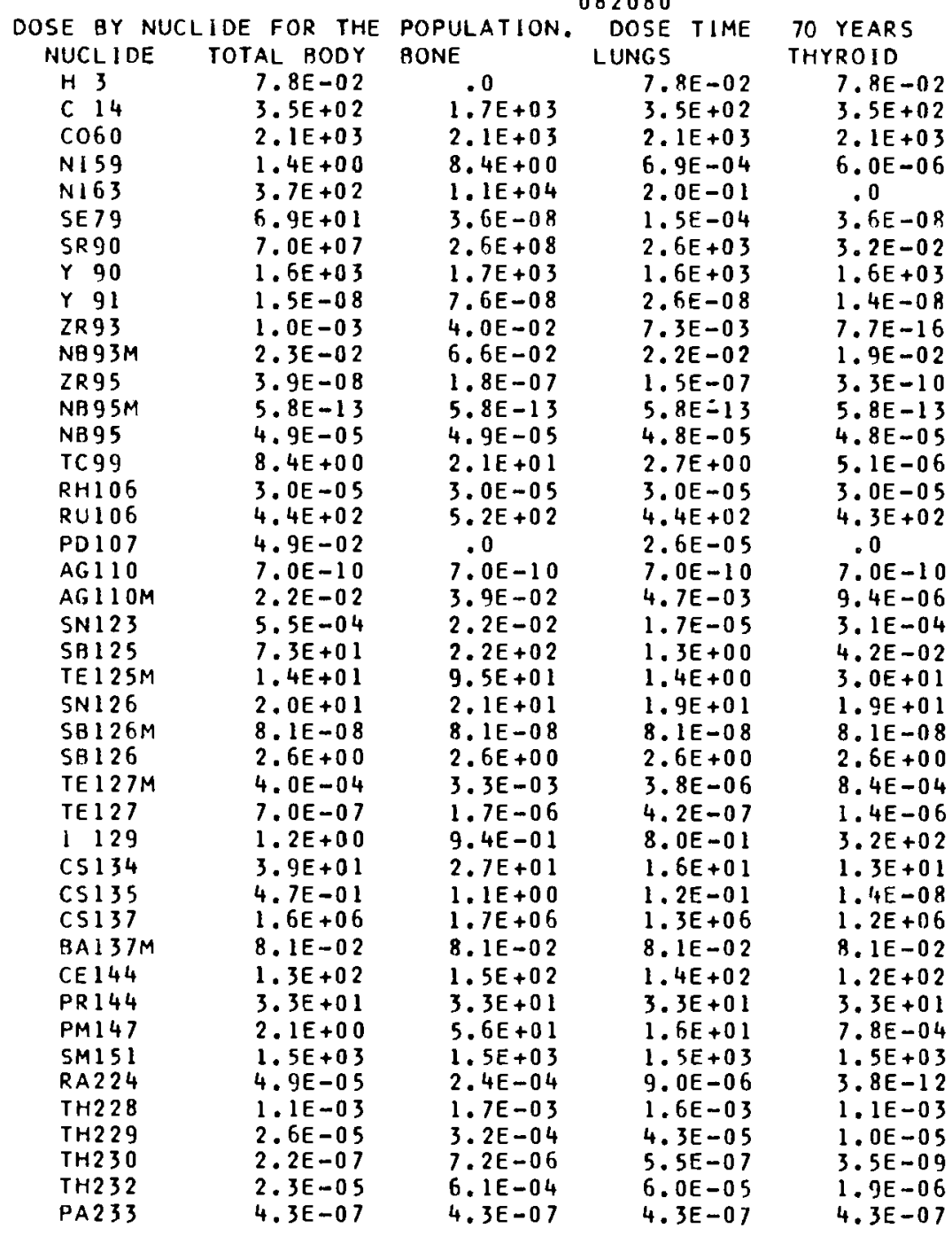

FIGURE E.1-2. ALLDOS Sample Problem Output 


$\begin{array}{lllll}U 232 & 2.4 E-04 & 3.3 E-03 & 7.9 E-04 & 3.4 E-07 \\ U 233 & 2.7 E-03 & 4.3 E-02 & 1.2 E-02 & 5.6 E-05 \\ U 234 & 2.8 E-03 & 4.4 E-02 & 1.3 E-02 & 7.6 E-05 \\ U 235 & 6.5 E-05 & 9.7 E-04 & 3.7 E-04 & 6.6 E-06 \\ U 236 & 5.9 E-09 & 9.5 E-08 & 2.8 E-08 & 5.0 E-12 \\ U 237 & 2.4 E-11 & 2.4 E-11 & 2.4 E-11 & 2.4 E-11 \\ U 238 & 1.4 E-03 & 2.2 E-02 & 8.3 E-03 & 4.3 E-05 \\ \text { NP237 } & 6.2 E-05 & 3.8 E-04 & 8.8 E-05 & 4.7 E-05 \\ \text { NP239 } & 1.9 E-02 & 1.9 E-02 & 1.9 E-02 & 1.9 E-02 \\ \text { PU238 } & 5.8 E-03 & 1.2 E-01 & 3.2 E-02 & 2.8 E-05 \\ \text { PU239 } & 1.8 E-01 & 3.7 E+00 & 7.9 E-01 & 4.7 E-04 \\ \text { PU240 } & 4.8 E-02 & 1.0 E+00 & 2.2 E-01 & 2.1 E-04 \\ \text { PU241 } & 2.1 E-02 & 5.6 E-01 & 1.1 E-02 & .0 \\ \text { PU242 } & 1.8 E-05 & 3.6 E-04 & 8.3 E-05 & 6.9 E-08 \\ \text { AM241 } & 2.4 E+00 & 4.2 E+01 & 6.9 E+00 & 7.6 E-01 \\ \text { AM242M } & 1.2 E-02 & 3.0 E-01 & 3.1 E-02 & 6.9 E-04 \\ \text { AM242 } & 3.2 E-07 & 7.4 E-06 & 5.8 E-05 & 2.4 E-10 \\ \text { AM243 } & 3.4 E-02 & 2.2 E-01 & 5.3 E-02 & 2.0 E-02 \\ \text { CM242 } & 3.3 E-04 & 5.3 E-03 & 1.0 E-02 & 9.9 E-05 \\ \text { CM244 } & 7.0 E-02 & 1.7 E+00 & 4.9 E-01 & 4.0 E-04 \\ \text { CM245 } & 4.2 E-05 & 3.6 E-04 & 7.2 E-05 & 2.8 E-05 \\ \text { ON FILE ON INPUT IEND }=3 & 3 & & \end{array}$

FIGURE E.1-2. ALLDOS Sample Problem Output 


\section{E.2 File 10 Inhalation Dose Factors}

The sample problem uses the File 10 data library shown in Appendix $C$ (Figure $\mathrm{C} .0-2)$. In addition to master radionuclide identification data, this library contains external and inhalation dose conversion factors. The external dose conversion factors were calculated as described in Section 3.1 using the computer program SUBDOSA* with input modified to represent a semi-infinite plume calculation. The calculation of these factors is relatively simple and will not be discussed further.

Inhalation dose factors were calculated using the computer program DACRIN (described in Section 3.2). A sample input deck for execution of DACRIN is presented here. The sample DACRIN problem will create inhalation dose conversion factors for the File 10 library. The organs considered (and organ index values) are listed in Table E.2-1.

Six cases are required for calculation of necessary inhalation dose factors. The factors represent the highest value calculated based on consideration of soluble and insoluble material. For all organs except the lungs and lower large intestine (LLI) the soluble form gives the highest values. The parameters for the six cases are as indicated in Table E.2-2. Details of other parameters are described in the DACRIN users manual (Section 4.0 References, Houston, Strenge and Watson 1976 and Strenge 1975). A listing of the DACRIN sample problem input deck is given in Figure E.2-1. The DACRIN output listing is not presented here because of space limitation. However, the dose factors calculated are given in the File 10 library listing.

* Strenge, D. L., E. C. Watson and J. R. Houston. 1975. SUBDOSA - A Computer Program for Calculating Individual External Doses from Accidental Atmospheric Releases of Radionuclides. BNWL-B-351, Pacific Northwest Laboratory, Richland, WA. 
TABLE E.2-1 DACRIN Sample Problem Organs

\begin{tabular}{lc}
\multicolumn{1}{c}{ Organs } & Index \\
Total body & \\
Kidney & 3 \\
Liver & 4 \\
Bone & 6 \\
Lungs & 8 \\
Thyroid & 16 \\
LLI & 23
\end{tabular}

TABLE E.2-2 DACRIN Sample Problem Input Parameters

\begin{tabular}{|c|c|c|c|c|c|c|}
\hline \multirow[b]{2}{*}{ Parameter } & \multicolumn{3}{|c|}{ Soluble Material } & \multicolumn{3}{|c|}{ Insoluble Material } \\
\hline & Case 1 & Case 2 & Case 3 & Case 4 & Case 5 & Case 6 \\
\hline Release type & Acute & Chron ic & Prolonged & Acute & Chronic & Prolonged \\
\hline Uptake time & 1 day & $1 \mathrm{yr}$ & $30 \mathrm{yr}$ & 1 day & $1 \mathrm{yr}$ & $30 \mathrm{yr}$ \\
\hline Dose time 1 & $1 \mathrm{yr}$ & 0 & $40 \mathrm{yr}$ & $1 \mathrm{yr}$ & 0 & $40 \mathrm{yr}$ \\
\hline $\begin{array}{l}\text { Dose time } 2 \\
\text { Ventilation }\end{array}$ & $50 \mathrm{yr}$ & $49 \mathrm{yr}$ & & $50 \mathrm{yr}$ & $49 \mathrm{yr}$ & - \\
\hline rate $\left(\mathrm{cm}^{3} / \mathrm{sec}\right)$ & 350. & 230. & 230. & 350. & 230. & 230. \\
\hline $\begin{array}{l}\text { Particle size } \\
(\mu \mathrm{m})\end{array}$ & 1.0 & 1.0 & 1.0 & & 1.0 & 1.0 \\
\hline
\end{tabular}




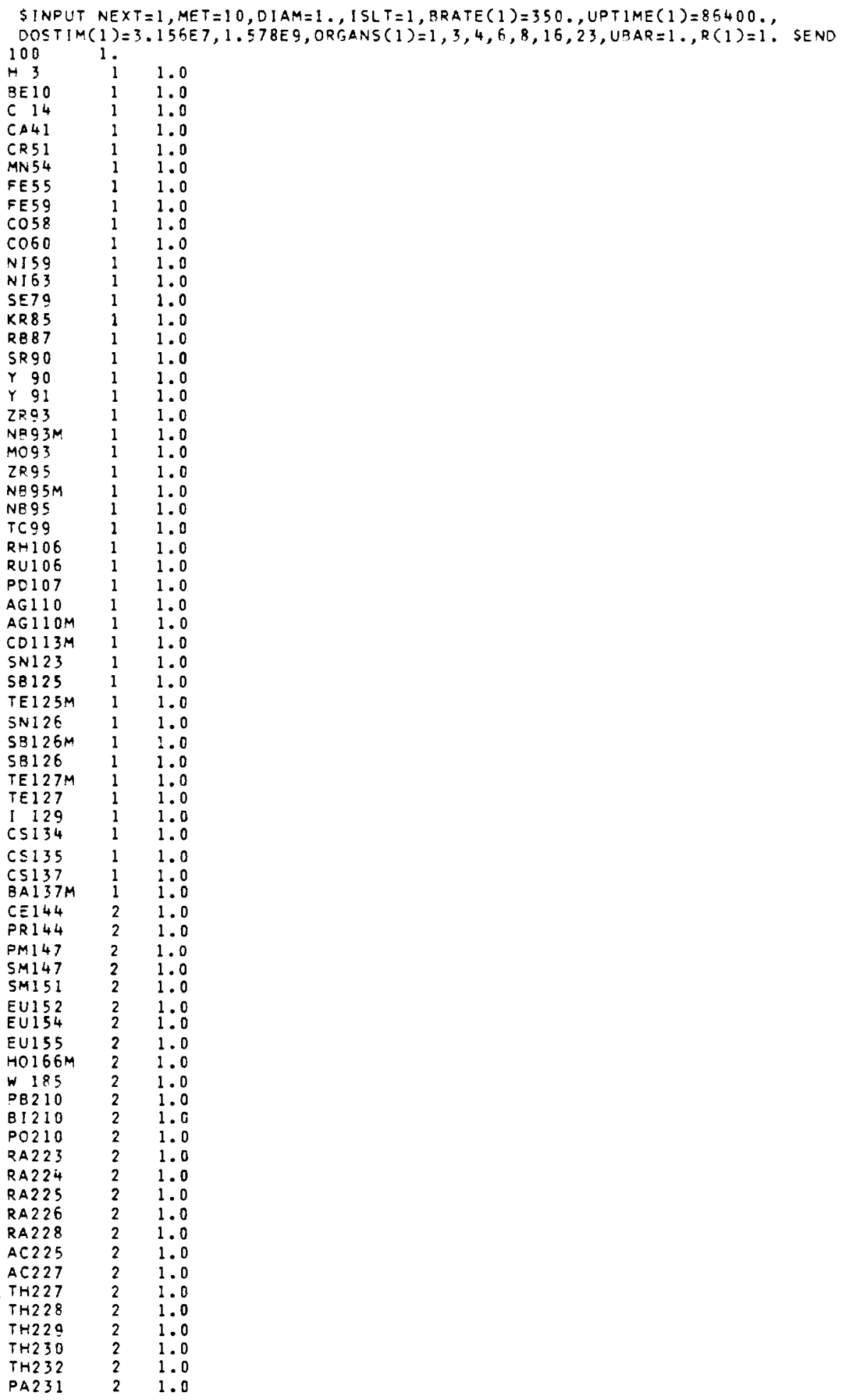

FIGURE E.2-1. DACRIN Sample Problem Input 


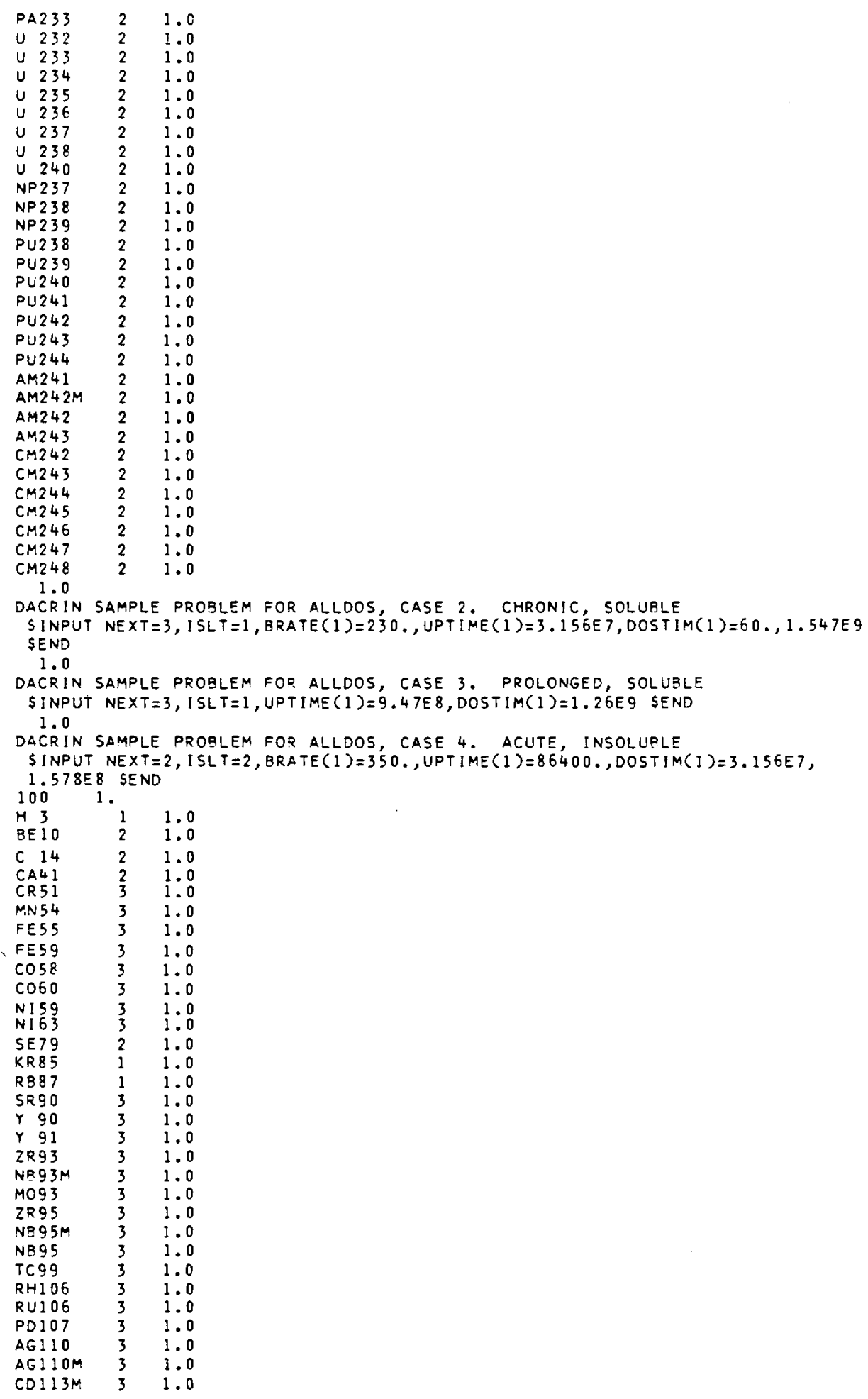

FIGURE E.2-1. DACRIN Sample Problem Input 


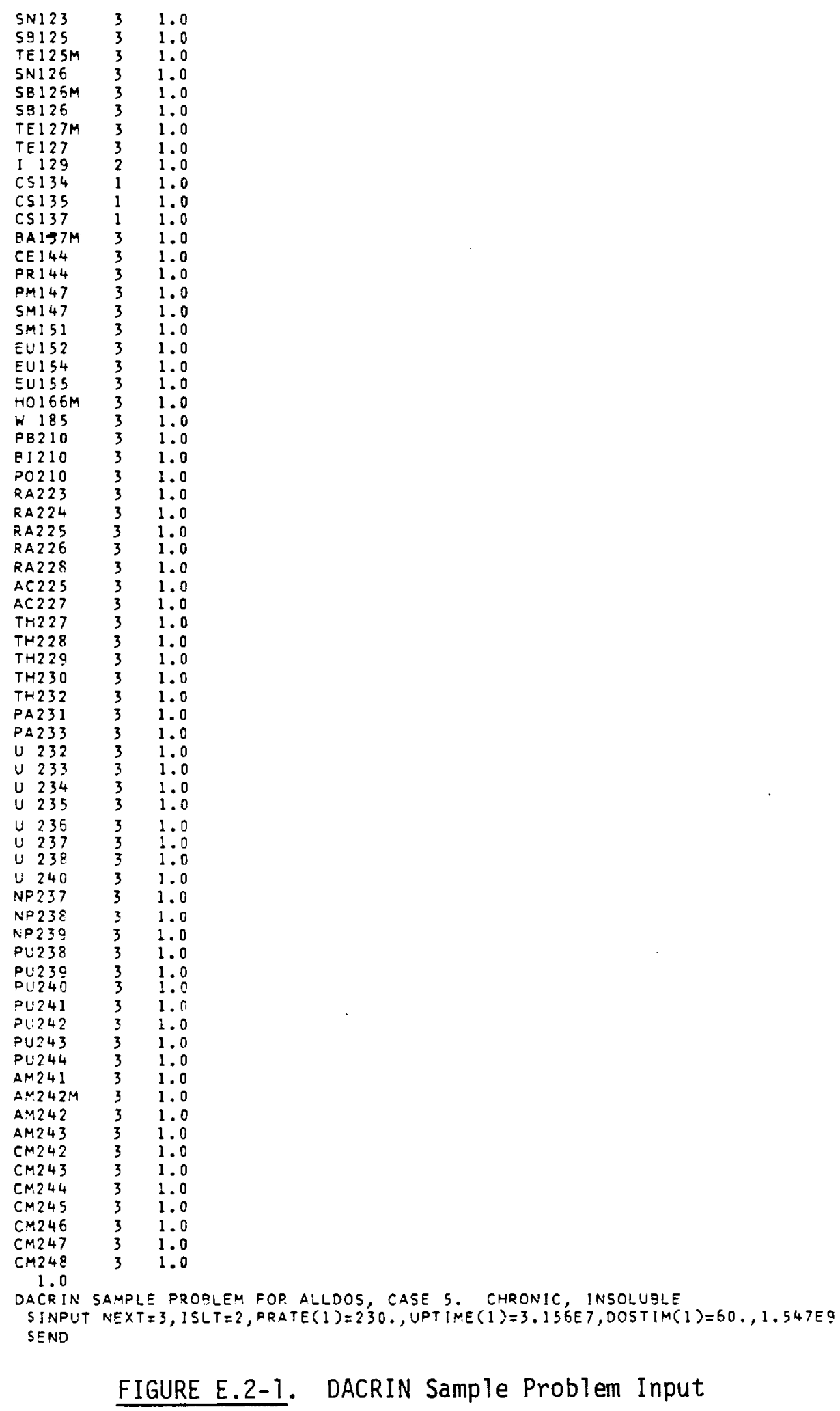

\section{E. 24}




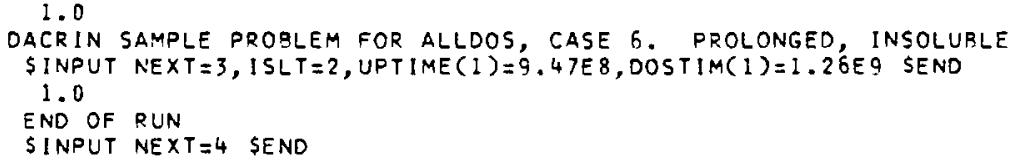

FIGURE E.2-1. DACRIN Sample Problem Input

4.

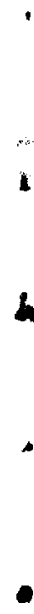

h 


\section{E.3 File 12 Dose Conversion Factors}

The terrestrial dose factor file (File 12) must be established on a sitespecific basis. Implicit in the data contained in this file are many of the demography and lifestyle assumptions that must be made for each site. The computer program PABLM (Napier 1980) is presently used to generate this file

The normal use of PABLM is to calculate accumulated radiation doses to individuals and populations from radionuclides in the environment. Doses can be calculated for up to five organs of reference for up to one hundred radionuclides per run. The program can calculate doses from nine food crop exposure pathways, five farm animal product exposure pathways, four external direct irradiation exposure pathways, the drinking water pathway, and four aquatic food product pathways. Any or all of the exposure pathways in PABLM may be utilized, depending on the modes of exposure possible at any particular location.

When run for ALLDOS, the radionuclide release inventory input to PABLM is set to one curie of each radionuclide for acute releases, and one curie per year for chronic releases. Thus, the resultant dose factors are in units of rem/Ci for acute releases, and rem/Ci-yr for chronic releases.

All sixteen required sets of dose factors may be created in a single PABLM run. Setting the NINEON control integer in the PABLM namelist to a positive value enables PABLM to print results to a permanent file that will become the ALLDOS File 12, with minimal interactive editing to add a title card. The individual sets of PABLM input should correspond in order with the definitions shown in Table B.2-1 in Appendix B.

The sample problem uses the File 12 data library shown in Appendix $C$ (Figure C.0-3). This data library was created using the program PABLM and the input deck shown in Figure E.3-1. Important parameters used in the sample problem are listed in Table E.3-1. Other program control parameters are described in the PABLM manual (Napier 1980). The PABLM sample output listing is not presented here because of space limitations. 


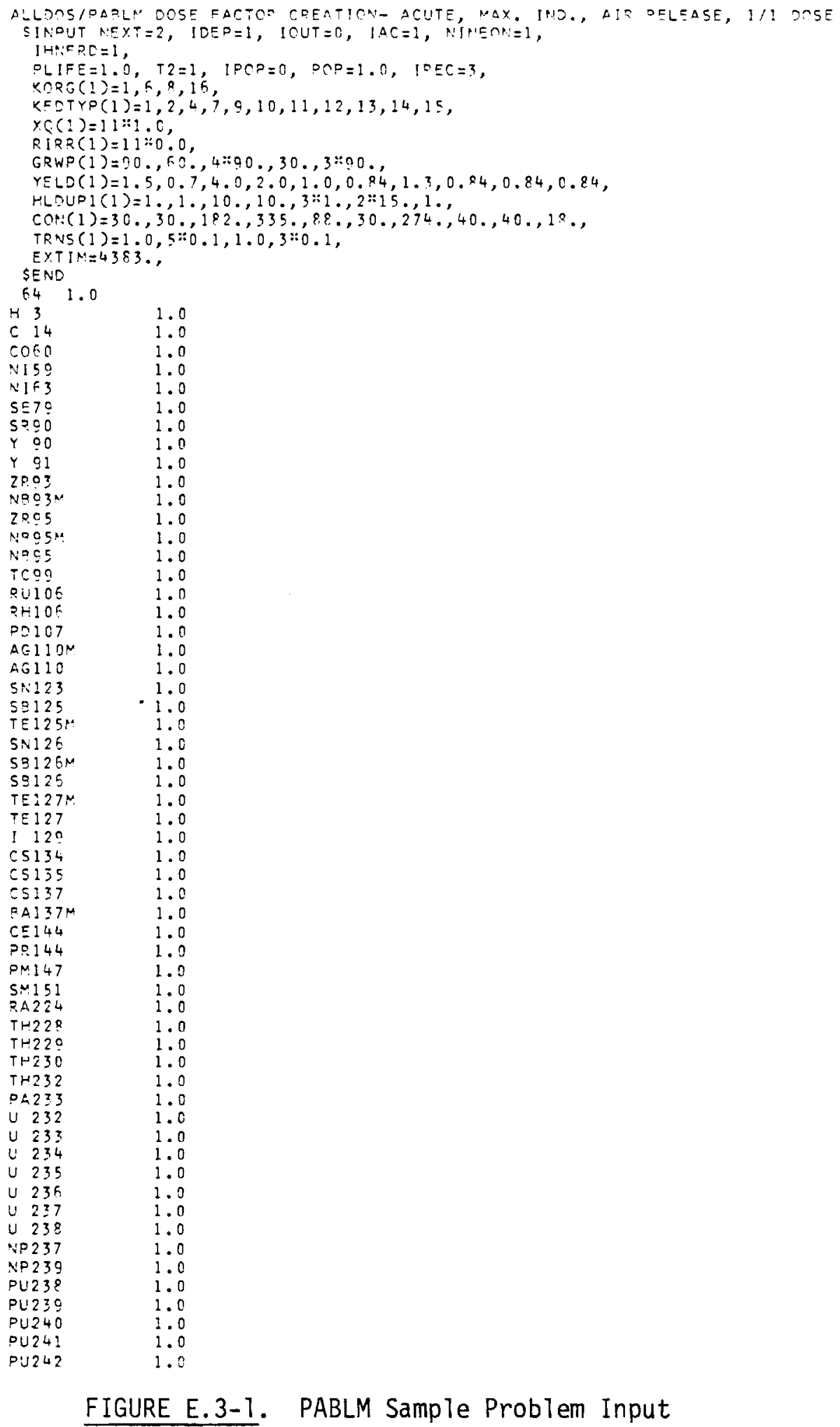

FIGURE E.3-1. PABLM Sample Problem Input 


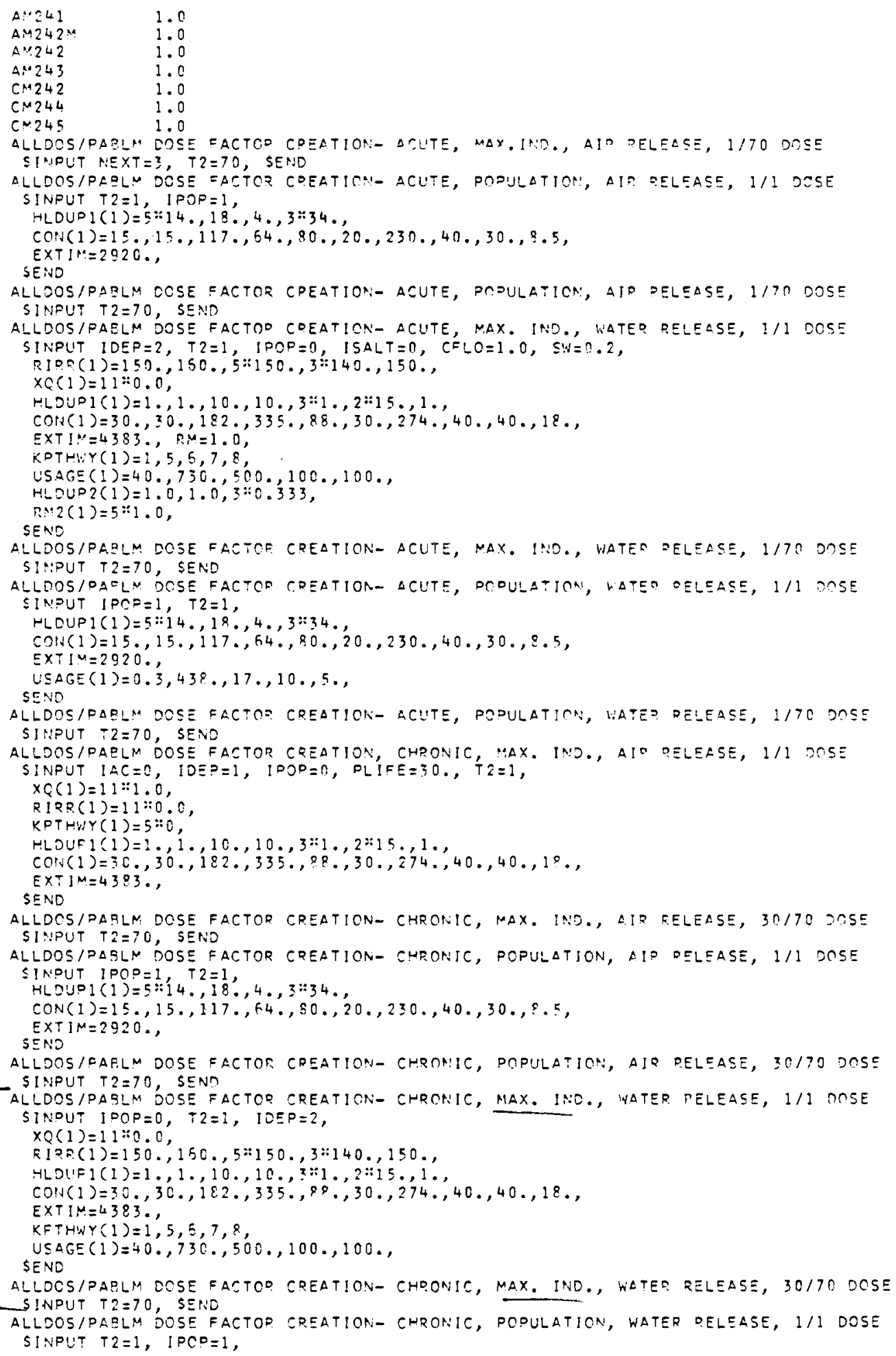

\section{FIGURE E.3-1. PABLM Sample Problem Input}




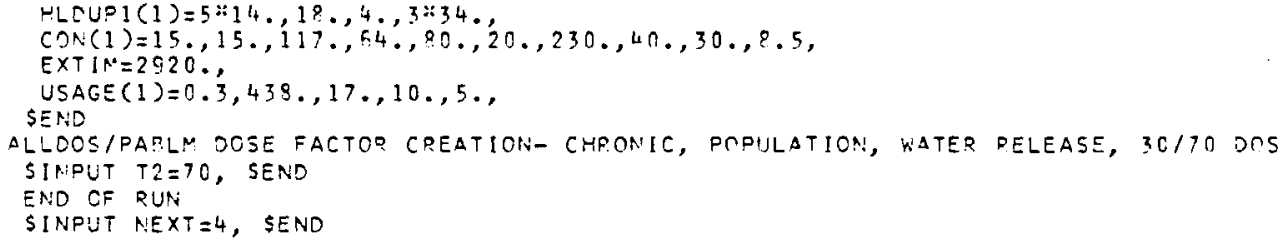

FIGURE E.3-1. PABLM Sample Problem Input 
TABLE E.3-1 PABLM Sample Problem Input Parameters

A. Site Specific Exposure Pathway Parameters

\begin{tabular}{|c|c|c|c|c|}
\hline $\begin{array}{l}\text { Exposure } \\
\text { Pathway }\end{array}$ & $\begin{array}{c}\text { Growing } \\
\text { Period } \\
\text { (Days) }\end{array}$ & $\begin{array}{l}\text { Yield } \\
\left(\mathrm{kg} / \mathrm{m}^{2}\right) \\
\end{array}$ & $\begin{array}{l}\text { Translation } \\
\text { Parameter } \\
\end{array}$ & 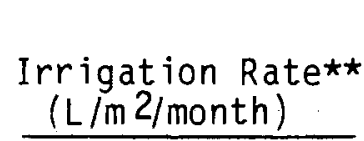 \\
\hline $\begin{array}{l}\text { Leafy vegetables } \\
\text { Other vegetables } \\
\text { Root vegetables } \\
\text { Orchard fruit } \\
\text { Grain } \\
\text { Eggs } \\
\text { Milk } \\
\text { Beef } \\
\text { Pork } \\
\text { Poultry }\end{array}$ & $\begin{array}{l}90 \\
60 \\
90 \\
90 \\
90 \\
90 \star \\
30 \star \\
90 \star \\
90 \star \\
90 \star\end{array}$ & $\begin{array}{l}1.5 \\
0.7 \\
4.0 \\
2.0 \\
1.0 \\
0.84^{\star} \\
1.3^{\star} \\
0.84^{\star} \\
0.84^{\star} \\
0.84^{\star}\end{array}$ & $\begin{array}{l}1.0 \\
0.1 \\
0.1 \\
0.1 \\
0.1 \\
0.1 \star \\
1.0 \star \\
0.1 \star \\
0.1 \star \\
0.1 \star\end{array}$ & $\begin{array}{l}150 \\
160 \\
150 \\
150 \\
150 \\
150 \star \\
150 \star \\
140 \star \\
140 \star \\
140 \star\end{array}$ \\
\hline
\end{tabular}

* Parameters for the feed and forage eaten by farm animals

** Used with liquid release pathways only

B. Site Specific Holdup and Consumption Rates

\begin{tabular}{|c|c|c|c|c|}
\hline $\begin{array}{l}\text { Exposure } \\
\text { Pathways }\end{array}$ & $\begin{array}{r}\text { Maximum } \\
\text { Ho ldup } \\
\text { (Days) }\end{array}$ & $\begin{array}{c}\text { Individual } \\
\text { Comsumption } \\
(\mathrm{kg} / \mathrm{yr})\end{array}$ & $\begin{array}{r}\text { Average } \\
\text { Holdup } \\
\text { (Days) } \\
\end{array}$ & $\begin{array}{l}\text { Individual } \\
\text { Consumption } \\
(\mathrm{kg} / \mathrm{yr}) \\
\end{array}$ \\
\hline Leafy vegetables & 1 & 30 & 14 & 15 \\
\hline Other vegetables & 1 & 30 & 14 & 15 \\
\hline Root vegetables & 10 & 182 & 14 & 117 \\
\hline Orchard fruit & 10 & 335 & 14 & 64 \\
\hline Grain & 1 & 88 & 14 & 80 \\
\hline Eggs & 1 & 30 & 18 & 20 \\
\hline Milk & 1 & 274 & 4 & 230 \\
\hline Beef & 15 & 40 & 34 & 40 \\
\hline Pork & 15 & 40 & 34 & 30 \\
\hline Poultry & 1 & 18 & 34 & 8.5 \\
\hline Fish* & 1 & 40 & 1 & 0.3 \\
\hline Drinking water* & 1 & 730 & 1 & 438 \\
\hline
\end{tabular}

* For liquid release analys is onty. 


\section{Other Required Parameters}

Maximum Individual Average Individual

Exposure to contaminated ground Exposure to contaminated sediment Swimming Boating $X / Q^{\prime}$

River flow rate
$4383 \mathrm{hr} / \mathrm{yr}$

$500 \mathrm{hr} / \mathrm{yr}$

$100 \mathrm{hr} / \mathrm{yr}$

$100 \mathrm{hr} / \mathrm{yr}$

$1.0 \mathrm{sec} / \mathrm{m}^{3}$

$1.0 \mathrm{ft}^{3} / \mathrm{sec}$
$2920 \mathrm{hr} / \mathrm{yr}$

$17 \mathrm{hr} / \mathrm{yr}$

$10 \mathrm{hr} / \mathrm{yr}$

$5 \mathrm{hr} / \mathrm{yr}$

$1.0 \mathrm{sec} / \mathrm{m}^{3}$

The computer program PABLM determines daughter radionuclide buildup in the environment. As a result the output from PABLM may contain more radionuclides than the number supplied as input. For example the PABLM sample problem gives 64 radionuclides as input but 87 radionuclides are supplied in the output file (see Figure $C .0-3$ ). The 23 additional radionuclides give environmental dose conversion factors per initial unit activity of parent. When the daughter is in equilibrium with the parent the dose factor is appropriate when the equilibrium activity of the daughter is given as input to ALLDOS. However, these factors are not of the proper form for long 1 ived daughters and should not be used. The sample problem output not be used. The sample problem output indicates some of these added radionuclides as unidentified "food library" radionuclides.

\section{E.4 File 15 Sample Problem Inventory}

To illustrate use of File 15 for radionuclide inventory specification a sample basic inventory library has been created. The title of the library is:

"ALLDOS Sample Problem Basic Inventory File"

This library contains two radionuclide inventory sets labeled:

"Decay for 1 year, Basic Inventory 1", and

"Decay for 5 years, Basic Inventory 2".

A listing of this data library is given in Figure E.4-1. Three radionuclide classes are defined for specification of release factors:

1. ${ }^{3} \mathrm{H},{ }^{14} \mathrm{C}$ and iodines

2. Fission and activation products

3. Actinides (including radionuclides ${ }^{224} \mathrm{Ra}$ and above)

These classes apply to specification of releases for all three release pathways (card type 4). The parameter NCL on card Type 3 sould be set to 3 . The sample problem will use the second inventory set which is indicated by setting the parameter INV to $5(=3+2)$. 


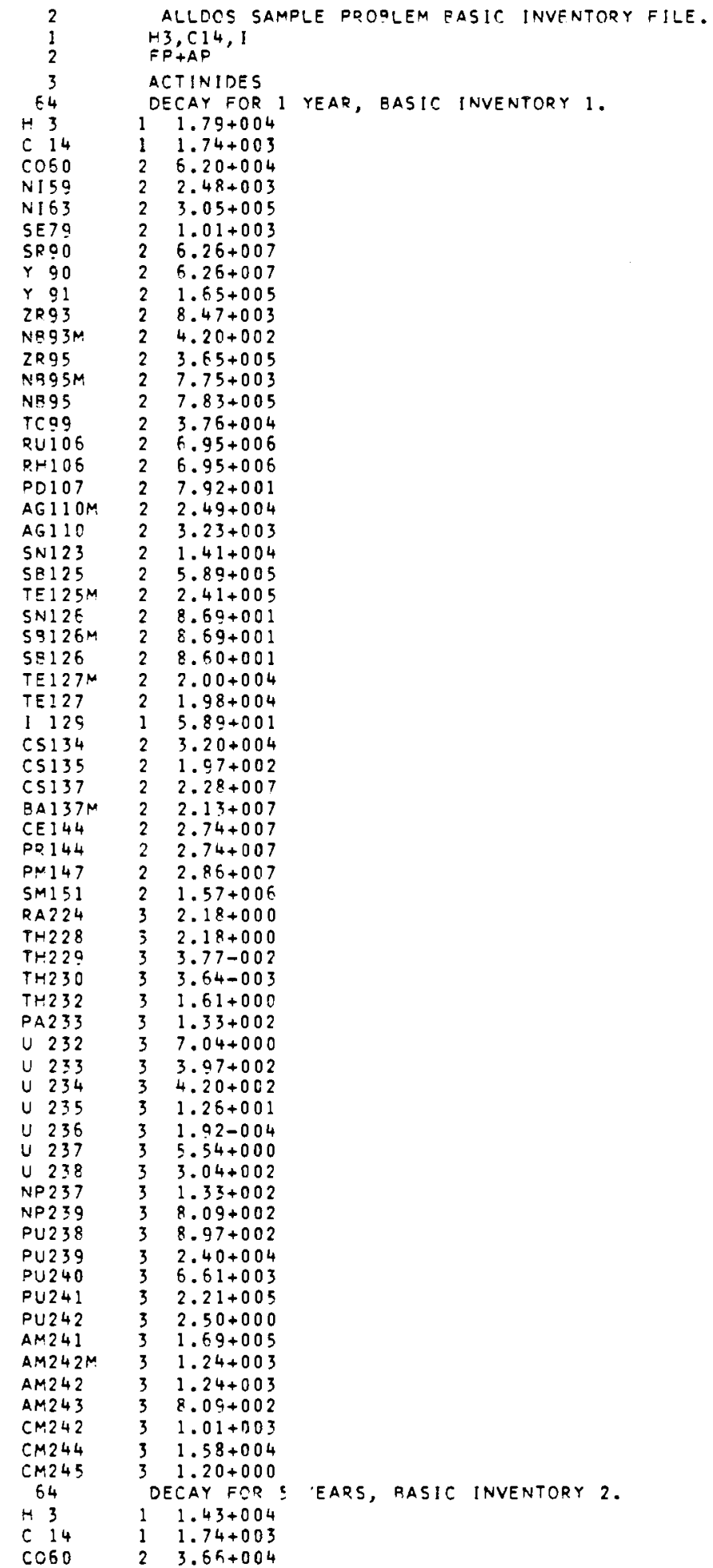

FIGURE E.4-1. File 15 Sample Basic Inventory 


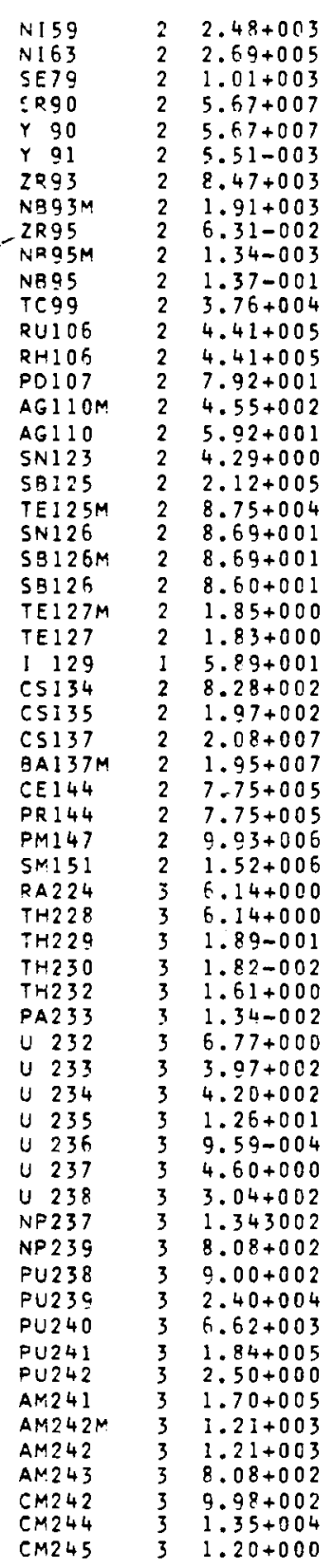

FIGURE E.4-1. File 15 Sample Basic Inventory 


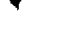




\section{DISTR IBUT ION}

No. of

Copies

$\underline{\text { OFFSITE }}$

\section{A. A. Churm DOE Patent Division 9800 S. Cass Avenue Argonne, IL 60439}

27 DOE Technical Information Center

ONS ITE

7 DOE Richl and Operations Office

P. A. Craig

H. E. Ransom

M. W. Shupe (5)

3 Hanf ord Engineering Development Laboratory

A. G. Blasewitz

R. E. Lerch

G. Richardson

20 Rockwell Hanford Operations

L. C. Brown

D. R. Gustavson

B. W. Hanson

A. R. Hawkins

W. M. Hayward

W. F. Heine

G. S. Hunt

R. L. Koontz (5)

$P$. G. Lorenzini

R. Y. Lyon

G. J. Pilicy

I. E. Reep

R. Shropshire

R. A. Watrous

D. D. Wodrich

D. E. Wood
No. of

Copies

ONSITE

64 Pacific Northwest Laboratory

J. B. Brown

J. B. Burnham

M. 0. Cloninger (2)

R. A. Craig

E. A. Eschbach

O. F. Hill

G. R. Hoenes

C. E. Jenkins

D. K. Landstrom

W. D. McCormack

K. S. Murthy

B. A. Napier (5)

R. A. Peloquin

J. V. Robinson

R. G. Schreckhise

K. A. Sebelien

J. K. Soldat

S. L. Stein

D. L. Strenge (30)

B. E. Vaughan

R. W. Wallace

E. C. Watson

M. G. Zimmerman

Technical Information (5)

Publishing Coordination (2) 
$\checkmark$

$-$

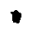

3

;

4 